\title{
Em busca do Cais do Valongo, Rio de Janeiro, século XIX
}

\author{
Tania Andrade Lima ${ }^{1}$ \\ Glaucia Malerba Sene ${ }^{2}$ \\ Marcos André Torres de Souza ${ }^{3}$
}

RESUMO: Este artigo relata os resultados da pesquisa arqueológica desenvolvida na zona portuária do Rio de Janeiro, no âmbito das obras de infraestrutura e revitalização urbana realizadas na região pela Prefeitura do Rio de Janeiro para as Olimpíadas de 2016 . Seu objetivo fundamental foi localizar os remanescentes do Cais do Valongo e do Cais da Imperatriz. $\bigcirc$ primeiro, construído em 1811 pela Intendência Geral de Polícia, por ordem do Príncipe Regente D. João VI. Adjacente ao mercado de escravos, e por onde passaram centenas de milhares de africanos escravizados para serem negociados, fazendo do Rio de Janeiro o principal porto de entrada desses cativos nas Américas. O segundo, Cais da Imperatriz, construído mais tarde, em 1843, por cima do Cais do Valongo, para o desembarque emblemático da princesa das Duas Sicílias, Teresa Cristina Maria de Bourbon, por ocasião do seu casamento com o imperador D. Pedro II. São apresentados a metodologia utilizada - um desafio na circunstância de ter que conciliar uma pesquisa científica com o apertado cronograma da obra -, o surgimento paulatino das estruturas edificadas, os contextos estratigráficos, a interpretação feita para o que foi encontrado, e as transformações urbanas decorrentes dos achados. Tendo em vista a alta relevância histórica, social e políitica do Cais do Valongo, o Instituto do Patrimônio Histórico e Artístico Nacional (lphan) encaminhou à Unesco, em setembro de 2015, um dossiê para a inscrição do Sítio Arqueológico Cais do Valongo na lista do Patrimônio Mundial, ora em apreciação.

PALAVRAS-CHAVE: Cais do Valongo. Cais da Imperatriz. Escravidão. Tráfico de escravos. Rio de Janeiro.

ABSTRACT: This article presents the results of archaeological research carried out in the Port Zone of Rio de Janeiro, as part of the infrastructural and urban revival projects being implemented in the region by the Rio de Janeiro City Council for the 2016 Olympics. Its basic objective was to localize the remains of the Valongo Wharf, built in 1811 by the Intendência Geral de Polícia, at the order of the Prince Regent Dom João VI. Adjacent to the slave market, hundreds of thousands of enslaved Africans passed through the wharf on the way to being sold, making Rio de Janeiro
1. Professora do Departamento de Antropologia do Museu Nacional, Universidade Federal do Rio de Janeiro. Pesquisadora do Conselho $\mathrm{Nac}$ ion a $1 \quad \mathrm{de}$ Desenvolvimento Científico e Tecnológico - CNPq. E-mail: <talima8@gmail. com>.

2. Professora do Departamento de Arqueologia, Universidade do Estado do Rio de Janeiro. Email: <gmalerba@hotmail. com>.

3. Professor do Departamento de Antropologia do Museu Nacional, Universidade Federal do Rio de Janeiro. Pesquisador do Conselho $\mathrm{Nac}$ ional $\mathrm{d}$ e Desenvolvimento Científico e Tecnológico - CNPq. Email:<torresdesouza@ yahoo.com>. 
the main port of entry for these captives in the Americas. The research also identified the remains of the Empress's Wharf, built later, in 1843, on top of the Valongo Wharf, especially for disembarkation of the Princess of the Two Sicilies, Teresa Cristina Maria de Bourbon, on the occasion of her marriage to Emperor Dom Pedro II. The article describes the methodology employed - a challenge given the need to reconcile a scientific study with the tight schedule of the construction work - as well as the slow emergence of the built structures, the stratigraphic contexts, the interpretation of what was found, and the urban transformations that resulted from the findings. Given the considerable historical, social and political relevance of the Valongo Wharf, in September 2015 the Instituto do Patrimônio Histórico e Artístico Nacional (Iphan) sent UNESCO a dossier for inclusion of the Valongo Wharf Archaeological Site on the list of World Heritage sites, presently under evaluation.

KEYWORDS: Valongo Wharf. Empress's Wharf. Slavery. Slave Trade. Rio de Janeiro.

Introdução

Os registros documentais informam ter sido o Rio de Janeiro, no século XIX, o principal porto de entrada de africanos para serem escravizados nas Américas, estimando-se em muitas centenas de milhares os que por ele passaram. Tamanha afluência visava atender sobretudo à demanda gerada pelas grandes lavouras de café do Vale do Paraíba fluminense, fortemente dependentes da mão de obra escrava, entre outras.

Ao chegarem, os tumbeiros ancoravam ao largo e eram submetidos à inspeção dos oficiais da Saúde, por conta das moléstias contagiosas que acometiam a carga humana que transportavam. Devendo cumprir quarentena até que fossem liberados para serem negociados, os africanos que conseguiam sobreviver às duras condições da travessia atlântica seguiam finalmente para o mercado do Valongo, regiãoperiférica da cidade, à época, para onde havia sido transferido o complexo relacionado ao comércio de carne humana, ao final do século XVIII. Contando com um lazareto para os isolamentos, com um cemitério para os que sucumbiam às doenças e aos maus tratos, e com as lojas onde as "peças" eram vendidas, esse complexo foi acrescido de um cais, construído formalmente em 1811 pela Intendência Geral de Polícia, bem próximo ao mercado, embora possa ter funcionado, não tão bem estruturado, anteriormente a essa data.

Esse complexo foi desativado em 1831 , por conta da lei que declarava livres todos os africanos chegados ao Brasil após a sua promulgação. Se esse golpe foi sentido pelo tráfico em um primeiro momento, logo em seguida novas estratégias foram concebidas para burlar a lei e ele prosseguiu impávido até 1850, quando acabou sendo de fato liquidado por uma nova lei que penalizava duramente os traficantes. Não obstante a desativação do mercado, o Cais do Valongo continuou funcionando para o transporte de toda sorte de mercadorias e de pessoas até 1843. Nesse ano, por decisão direta do Imperador D. Pedro II, ele foi inteiramente reformado para receber a princesa das Duas Sicílias, Teresa Cristina Maria de Bourbon, com quem ele se casara por procuração e que agora 
chegava da Itália para ser a Imperatriz do Brasil. Sobre o Cais do Valongo foi construído um novo atracadouro, renomeado como Cais da Imperatriz, relegando seu antecessor ao esquecimento.

No início do século XX, por ocasião das obras de construção do Porto do Rio de Janeiro, o cais foi novamente aterrado. A república nascente, no bojo do seu compromisso com a modernidade, soterrou um emblema do império, promovendo mais uma vez, tal como este último fizera em relação ao Valongo, o apagamento de uma etapa que se pretendia definitivamente ultrapassada e, tanto quanto possível, esquecida.

Cem anos depois, o programa de remodelamento da degradada zona portuária da cidade para as Olimpíadas de 2016, ao realizar intervenções em subsolo para obras de infraestrutura urbana, proporcionou uma oportunidade única para a arqueologia investigar se, porventura, remanescentes dos dois cais teriam se preservado no local que thes era historicamente atribuído. Um projeto foi especialmente concebido para encontrá-los, com o foco mais direcionado para o Cais do Valongo, pela sua indiscutível importância para a comunidade descendente e para a história da escravidão no Brasil, mas, sobretudo, por ele ter sido varrido da memória social do povo brasileiro. Nas situações em que o passado é deliberadamente esquecido e enterrado para que dele não se fale mais, a arqueologia histórica é um poderoso instrumento para recuperar e fazer lembrar o que em algum momento se pretendeu esquecer, funcionando como um antídoto contra amnésias sociais. E o Valongo foi trazido de volta, exatamente duzentos anos depois, em 2011.

Este artigo relata passo a passo o desenvolvimento da pesquisa de campo, a metodologia de trabalho adotada, bem como o surgimento paulatino das estruturas e dos remanescentes de ambos os cais, até a sua completa exposição, além da interpretação do que foi encontrado. Somando-se a outras publicações anteriores sobre a investigação realizada ${ }^{4}$, seus aspectos sociopolíticos ${ }^{5}$ e o significado de elementos da cultura material recuperadab, ele tem como objetivo fundamental apresentar os remanescentes edificados que vieram à tona com as escavações arqueológicas.

O trabalho realizado oferece a possibilidade de se fazer um confronto entre o registro documental existente sobre a região do Valongo ao longo do século XIX e o registro arqueológico resultante das intervenções. Ao contrário do que se observa em muitas circunstâncias em que a arqueologia promove esse confronto entre o que foi escrito e o que foi de fato feito, não existe qualquer contradição entre ambos. Os achados referentes aos diferentes processos pelos quais passou a atual Praça Jornal do Commercio estão ancorados no registro documental, de tal forma que a contribuição oferecida pela pesquisa arqueológica reside fundamentalmente na exposição da sua materialidade. $\bigcirc$ que, no caso do Cais do Valongo, fala muito de perto aos sentidos, às emoções, com uma contundência que provoca forte impacto sobre a sensibilidade humana, de tal forma que pode estimulá-la na direção de ações transformadoras. Suas pedras exalam racismo,
4. Ver Tania Andrade Lima (2013a).

5. Ver Tania Andrade Lima (2013b).

6. Ver Tania Andrade Lima Marcos André Torres de Souza; Glaucia Malerba Sene (2014). 
7. Instruções do Marquês do Lavradio ao seu sucessor como Vice-Rei. Arquivo Nacional, Rio de Janeiro, Caixa 746, Fundo Vice Reinado. intolerância e opressão no limite, de modo que sua exposição provoca reflexões e inspira consciência social. Mais ainda, opera como um antídoto contra a amnésia social instalada em alguns dos mais dolorosos episódios do regime escravista, entre eles, a chegada, pelo Cais do Valongo, de africanos para serem escravizados no Brasil.

\section{Cais do Valongo}

Em 1779, ao deixar o vice-reinado do Brasil, D. Luís de Almeida Soares Alarcão, Marquês do Lavradio, apresentou ao seu sucessor, D. Luís de Vasconcelos e Souza, um alentado relatório, visando orientá-lo em seus novos encargos. Nele expôs a situação militar, política e civil da capitania do Rio de Janeiro ao longo de sua administração, bem como as iniciativas e medidas por ele tomadas para sanar alguns de seus problemas. Entre muitas outras, a transferência do mercado de escravos, que funcionava à Rua Direita, a principal da cidade então, para um local periférico, na região do Valongo. $O$ desfile de negros seminus, esquálidos e pestilentos no centro políitico, econômico, administrativo e religioso da cidade, que tinha como epicentro o Paço dos Vice-Reis, por certo trazia constrangimento e medo às elites, receosas de serem contaminadas com suas doenças. Por conta disso, era preciso remanejá-los para bem longe, para um local de menor exposição e visibilidade, onde não constituíssem uma ameaça nem provocassem tanto desconforto.

Foi a resolução ordenar que todos os escravos que viessem nestas embarcações, logo que dessem sua entrada na Alfândega, pela porta do mar, tornassem a partir e embarcassem para o sitio chamado Valongo, que é no subúrbio da cidade separados de toda comunicação e que ali se aproveitassem das muitas casas e armazéns que ali há para os terem e que àqueles sítios fossem as pessoas que os quisessem comprar e que os compradores nunca pudessem entrar com mais de 4 ou 5 na cidade [e] que os precisassem de ser vestidos e que enquanto os não conduziam para as minas ou para suas fazendas depois de comprados os tivessem no campo de São Domingos onde tinham todas as comodidades e livravam a cidade dos incômodos e prejuízos que há tantos anos se recebia por causa da sobredita desordem. Vigiei muito cuidadosamente sobre a execução desta ordem; ainda que com trabalho consegui que ela se executasse; visivelmente se conheceu os benefícios que receberam na saúde os povos; até os mesmos escravos se restituíam mais facilmente das moléstias que traziam; aquele grande fétido que havia já não se sente; e hoje todos conhecem o beneficio que daqui thes tem resultado?.

O termo Valongo, forma apocopada de vale longo, designava o talvegue existente entre os morros da Conceição e do Livramento, por onde escoavam as águas que desciam por suas encostas e mais aquelas oriundas das áreas pantanosas do interior da cidade para desaguar na baía. Na desembocadura desse canal de drenagem, alongado e sinuoso (Figuras 1, 2 e 3), o aporte de sedimentos oriundos de fluxos vindos do continente trazia e acumulava abundante material clástico, o que resultou, ao longo do tempo, em uma feição de pontal (Figura 4). 


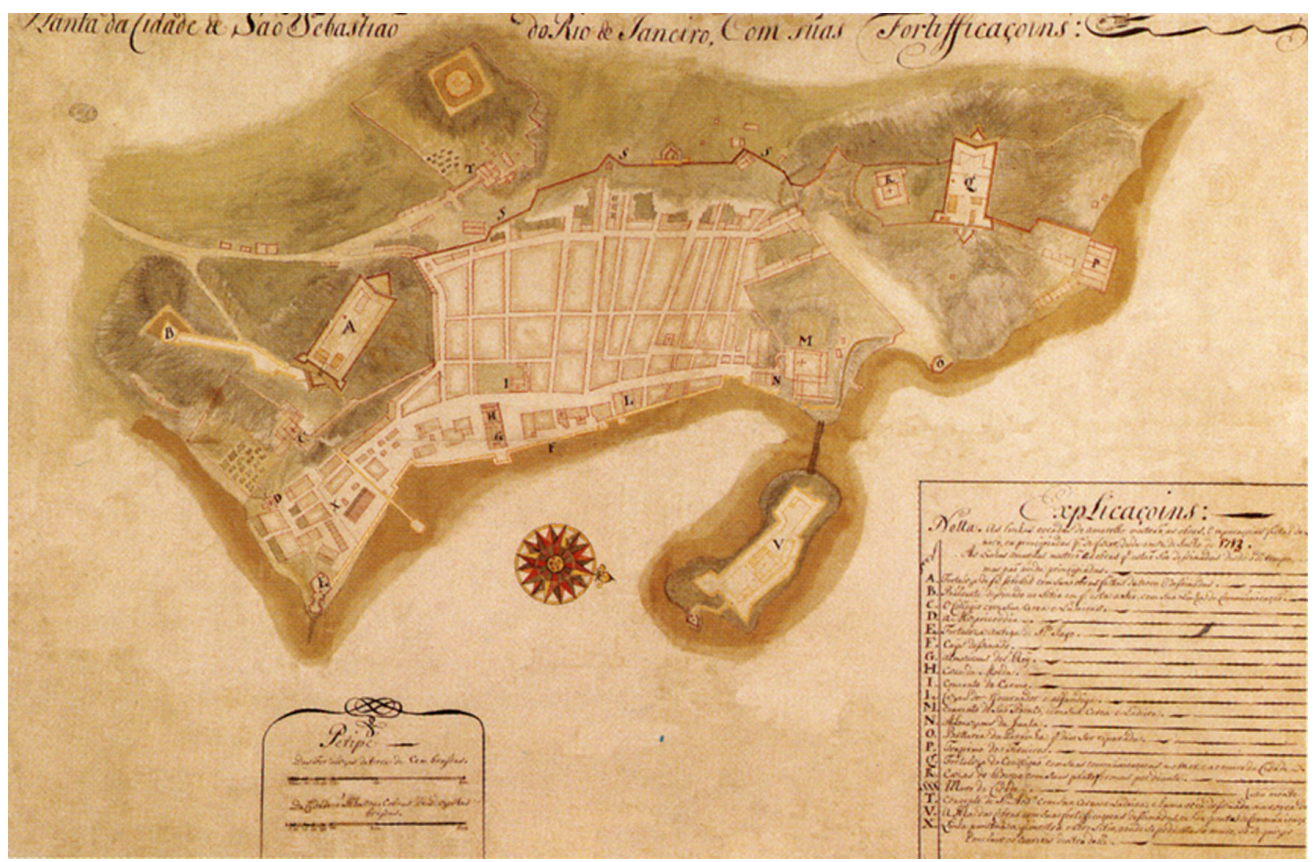

Figura 1- Planta da cidade de São Sebastião do Rio de Janeiro com suas fortificações, de autoria do engenheiro militar Jean Massé, de 1713, mostrando à direita e ao alto a região do Valongo, então um local ermo,

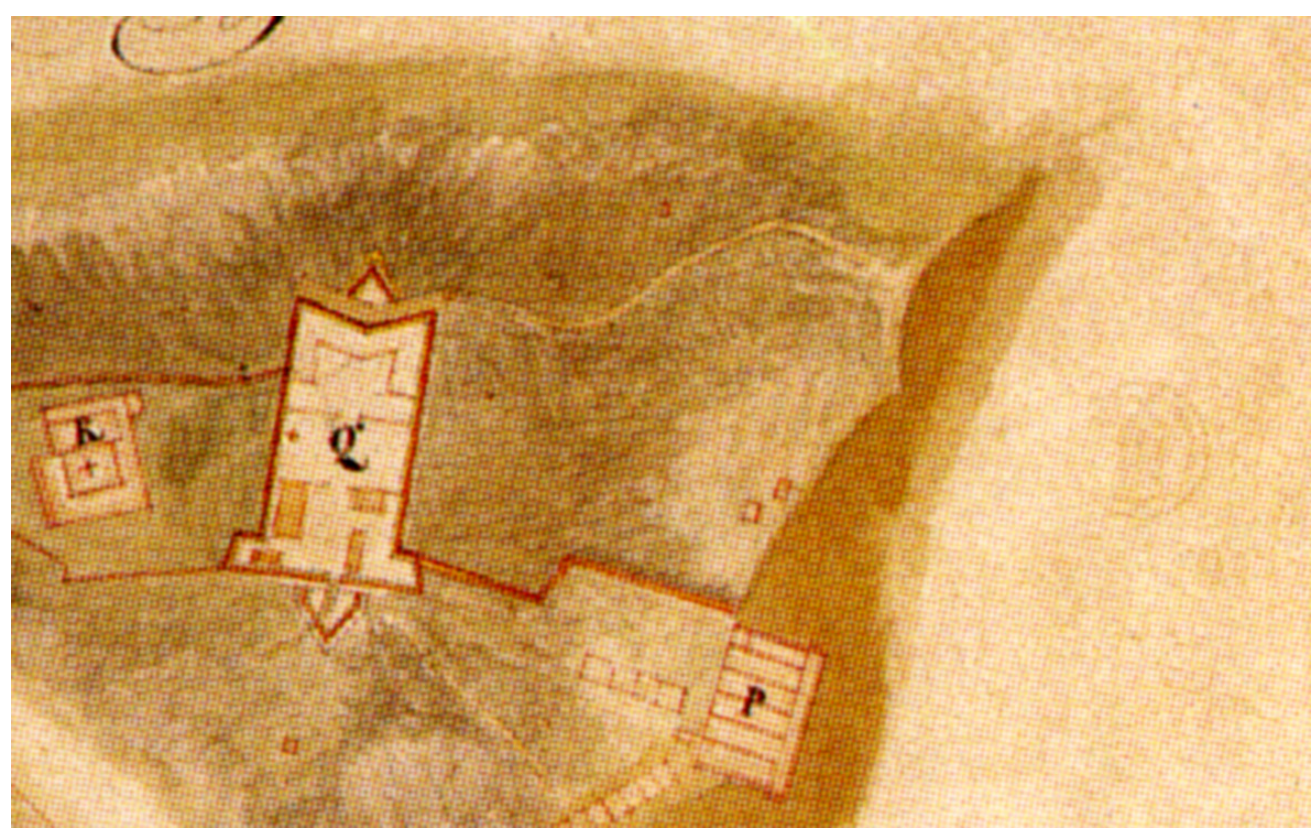

Figura 2 - Detalhe do mapa de Jean Massé, em que se vê a conformação do talvegue, em meio aos dois morros - o da Conceição e o do Livramento -, e a linha sinuosa do canal natural de drenagem. 


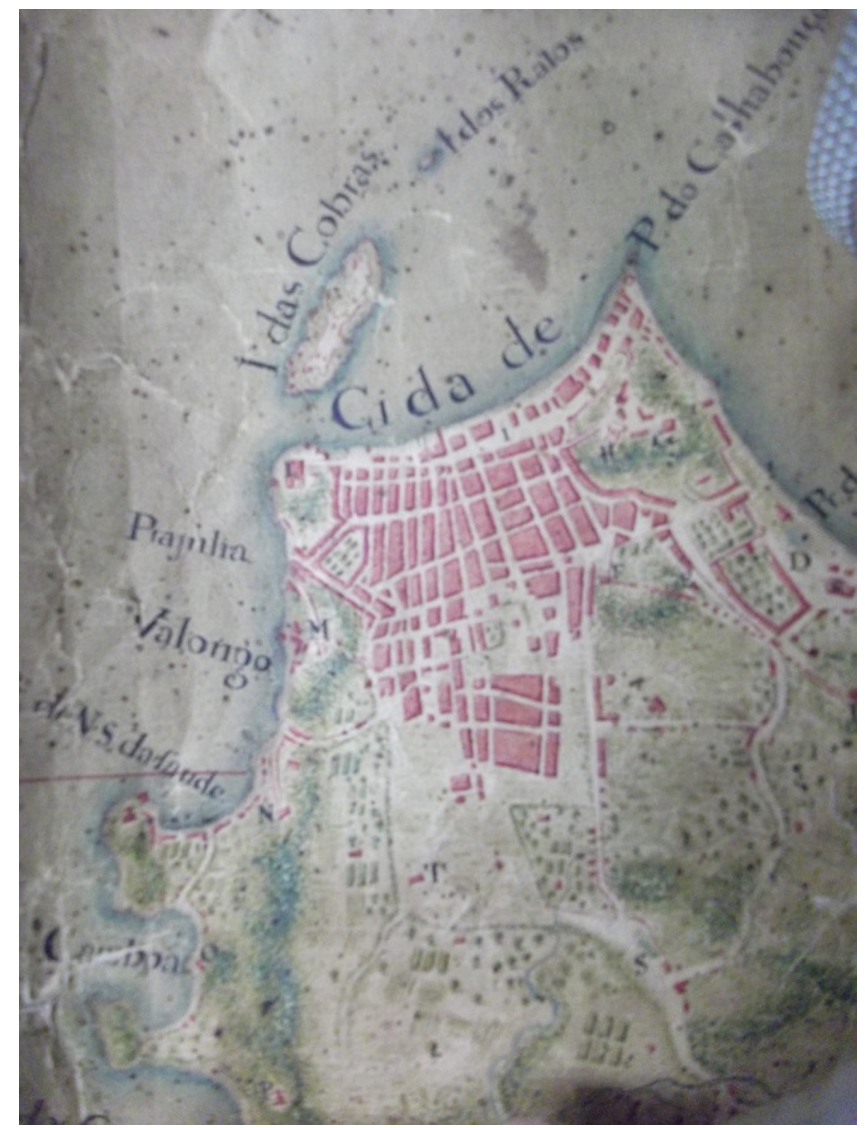

Figura 3 - Carta Topográfica da Cidade de São Sebastião do Rio de Janeiro, de cerca de 1750, de autoria de André Vaz Figueira. Nela vê-se à esquerda, entre os dois morros, a linha sinuosa do canal de drenagem no Valongo, então efetivamente um subúrbio da cidade, ainda pouco povoado.

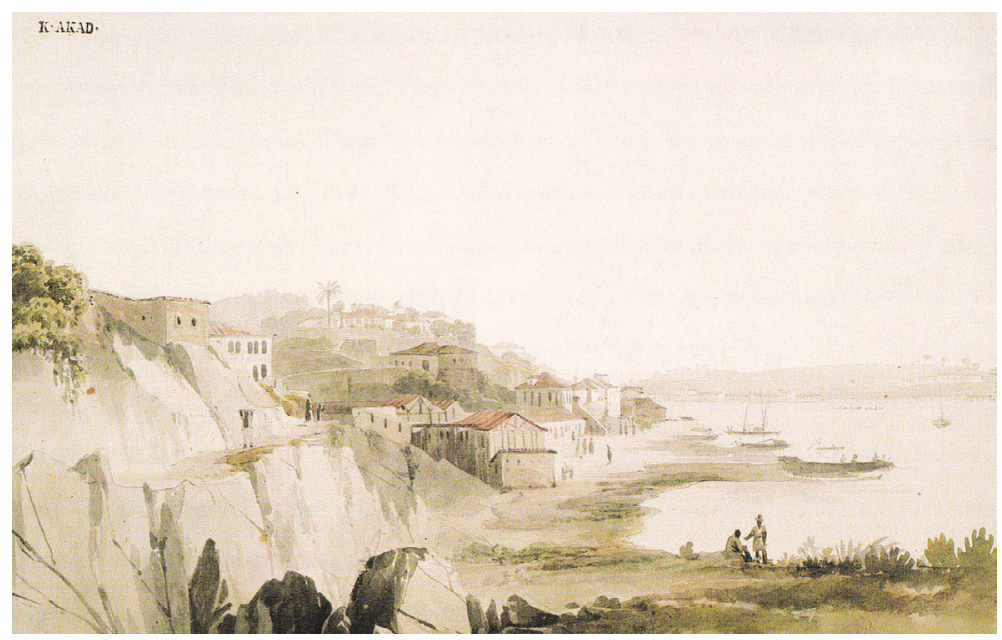

Figura 4 - Aquarela de autoria de Thomas Ender, 1817, intitulada "Cercanias de Val-Longo". Em primeiro plano, a grande pedra da Prainha, derrubada poucos anos depois; e, mais adiante o pontal do Valongo. Acervo Kupferstichkabinett der Akademie der bildenden Künste, Viena. 
Pelo relatório deixado pelo Marquês do Lavradio, fica claro que, ao fim do seu governo, sob sua vigilância direta e expressa, o mercado já tinha sido transferido para o Valongo, e o desembarque dos escravos, após darem entrada na alfândega, deveria ser feito naquela região. Contudo, não se sabe precisamente quando o local começou a funcionar de fato como ponto de desembarque de africanos recém-chegados, após sua determinação.

Um documento datado de $1811^{8}$, pelo qual negociantes de escravos argumentavam contra algumas determinações do Alvará de 22 de janeiro de 18109, com força de lei, que dava regimento ao Provedor Mor da Saúde dispunha, entre outros, sobre o transporte e o desembarque de escravos no Rio de Janeiro. Em seu $\S 5$ é dito que "os navios que trouxerem carregação de escravos esperarão no ancoradouro do Poço ou no da Boa Viagem, até que se faça a visita da Saúde pelo Guarda-mór e demais oficiais; e feita ela, irão ancorar e ter quarenta [sic] no ancoradouro da llha de Jesus".

\section{parágrafo seguinte determinava que}

no ato da visita se determinarão os dias que cada um destes navios deve ter de quarentena, conforme as moléstias que trouxer, mortandade que tenha havido, e mais circunstâncias que ocorrerem; porém nunca terão de quarentena menos de oito dias, em que os negros estejam desembarcados e em terra na referida llha para aí serem tratados, fazendo-os lavar, vestir de roupas novas, e sustentar de alimentos frescos; depois do que se lhes dará o bilhete de saúde e poderão entrar na cidade para se exporem à venda no sítio estabelecido do Valongo.

Argumentavam os negociantes em seu documento sobre o prejuízo que essa determinação trazia ao comércio de escravos, pois que se

os seus navios devem vir para o ancoradouro da llha de Jesus, pode(-se) dispensar a espera nos ancoradouros do Poço ou Boa Viagem, onde são expostos a inconvenientes do mar, pois é certo que sempre entram com a viração da tarde, que é muitas vezes rija, e nem sempre podem vir preparados de ferros e amarras para sofrerem aquele ancoradouro.

Esse documento deixa claro onde era feito o desembarque em 1811 - ou no ancoradouro do Poço ou no da Boa Viagem, e por fim, no da Iha de Bom Jesus - inexistindo qualquer referência ao Valongo, senão como destino final, depois de os escravos terem desembarcado e cumprido a necessária quarentena, após o que poderiam ser negociados nos armazéns lá existentes.

Por outro lado, após a chegada da corte portuguesa, uma declaração do Intendente Geral de Polícia da Corte e do Estado do Brasil, o Desembargador do Paço e Ouvidor da Corte Paulo Fernandes Viana, datada de 30 de maio de $1811^{10}$, afirma que, por ordem de Sua Alteza Real o Príncipe Regente, mandara fazer uma rampa e um cais de pedra na praia do Valongo.
8. Manuscritos, BN II-34, 26, 19. "Representação dos proprietários, consignarários e armadores de resgate de escravos a SAR [RJ, 1811]". Biblioteca Nacional, Rio de Janeiro.

9. Alvará de Regimento de 22 de janeiro de 1810. In: Leis Históricas. Disponível em: <http://www.planalto. gov.br/ccivil_03/revista/ Rev_70/alvara.htm>, acesso em 28 abr. 2015.

10. Aforamentos. Arquivo Nacional, Rio de Janeiro, BR RJ RIO BI O D16 O O389, Folha 9. 
11. Cf. Abreviada demonstração dos trabalhos da polícia em todo tempo em que serviu o Desembargador do Paço Paulo Fernandes Vianna. Revista do Instituto Histórico e Geográfico Brasileiro (1892, p.373-74).

12. Cf. Júlio Cesar Medeiros Pereira (2007, p.76).
Atesto que sendo ordem de Sua Alteza Real para mandar fazer uma rampa e cais correspondente a ele na praia do Valongo; e precisando-se para esta obra de avultada porção de pedra, o tenente-coronel Julião José de Oliveira proprietário das pedreiras da Conceição a ofereceu gratuitamente toda a pedra que fosse necessária para aquela obra, ainda para outra qualquer que a polícia precisa fazer naquele sítio, tirada das suas pedreiras, cuja oferta foi aceita e se fez a mencionada rampa e cais com a pedra tirada das referidas pedreiras, no que a Intendência deixou de despender avultada quantia (...)

Essa declaração foi reiterada no relatório por ele produzido ao deixar a Intendência, em 1821, no qual informou o que se segue: "Fiz o Cais do Valongo no fim da rua deste nome com rampas e escadas para embarque, que foi de suma utilidade por não haver em certas estações local mais cômodo para embarques e desembarques, e iluminei com lampiões o mesmo cais ${ }^{11 "}$.

O fato de ambos os documentos - o do Intendente de Polícia e o dos negociantes de escravos - serem datados de 1811 permite supor que, se o cais do Valongo estava em obras, tal como relatado pelo Intendente Paulo Viana, ele não podia ser utilizado como local de desembarque, sendo necessária a utilização dos demais ancoradouros, tal como mencionado. Essa hipótese permite conciliar os diferentes documentos existentes, à primeira vista contraditórios.

A determinação do Marquês do Lavradio para a transferência do mercado de escravos, seguida da construção do cais transformaram em pouco tempo "o subúrbio da cidade separado de toda comunicação", segundo suas palavras, em uma movimentada região. Pereira assinala que, em 1817, o Valongo se tornou um local intensamente frequentado, com cerca de 34 grandes estabelecimentos comerciais, entre eles casas de importação e exportação, trapiches e depósitos de armadores, descrevendo o movimento incessante no cais por conta do mercado: "Sumacas, patachos e bergantins desembarcavam escravos, enquanto outras tantas embarcações menores cuidavam de transportá-los para outras regiões litorâneas, da Corte ou fora dela"12

Uma portaria datada de 26 de março de 1822, dirigida ao Intendente Geral da Polícia interino que substituíra Paulo Fernandes Viana, não deixa dúvidas quanto ao Valongo ser o local de desembarque dos escravos. Assinada pelo Ministro e Secretário de Estado dos Negócios do Reino, José Bonifácio de Andrada e Silva, transmitia a seguinte recomendação de Sua Alteza Real, o Príncipe Regente:

Tendo chegado ao conhecimento de S.A.R. O Príncipe Regente, as justas queixas dos moradores da rua do Vallongo, contra o abuso com que a maior parte dos Negociantes que traficão em escravos, tendo em vista unicamente os seus interesses particulares, não só fazem desembarcar de bordo dos Navios os escravos de ambos os sexos quase nús, como os conservão, faltando aos deveres da decência e cevilisação, nesse mesmo estado até os venderem, com escabrosa offensa e risco de vida daqueles moradores, por que além de fazerem, com reconhecida infracção das ordens recebidas, conduzir para o interior da povoação, escravos infectados e já moribundos que deverão ser depositados no Lazareto, comettem muitos outros excessos e até falta de caridade christã na condução dos cadáveres para o Cimitério. Manda o Mesmo Augusto Senhor pela Secretaria de Estado dos negocios do Reino recomendar mui positivamente ao Intendente Geral da 
Policia interino, a maior vegilancia sobre taes abusos não só prejudiciaes à saúde publica, como também escandalosos e offensivos à decencia e decoro das famílias, a fim de que dando a Policia sobre esse objeto as mais activas e efficazes providencias, se evite para o futuro a continuação de tão prejudiciaes como estranhaveis procedimentos. Palácio do Rio de Janeiro, em 23 de março de 1822. José Bonifácio de Andrada e Silva, Ministro e Secretário de Estado dos Negócios do Reino ${ }^{13}$.

Esses documentos expõem de forma clara os componentes do complexo formado na região do Valongo para o comércio de carne humana: o cais, local de desembarque dos africanos recém-chegados; o mercado, na rua do Valongo, onde eram negociados os que se encontravam em condições de serem vendidos ${ }^{14}$ (Figuras 5 e 6); o lazareto, na Gamboa, onde deveriam ser isolados em quarentena os que se encontravam infectados e os já moribundos; e o cemitério dos Pretos Novos, à rua Pedro Ernesto, onde deveriam ser enterrados os que faleciam ${ }^{15}$. Vê-se, por meio desse documento, que as condições reclamadas décadas antes pelo Marquês do Lavradio para o comércio de escravos no centro da cidade foram mantidas, ou mesmo pioradas, com a transferência do complexo para a região do Valongo.

A agitação decorrente do fluxo constante não apenas de escravos, mas de toda sorte de mercadorias pelo cais pode ser medida em documento encaminhado ao príncipe regente, em 182916, por mercadores residentes no Valongo que se queixavam da movimentação frenética naquele local decorrente do

desembarque constante e diário de lenhas, madeiras, tijolos, cal, telhas, capins, frutas e outros muitos gêneros em ponto grande nos barcos e canoas costeiras que ali aportam de dia e de noite; há para embarques e desembarques de milhares de pessoas uma única rua [a do Valongo] pela qual se faz a exportação de gêneros alimentícios e a importação dos que vêm de fora e é tanta concorrência de povo e de tudo o mais que embarca e desembarca, que sempre a rua e sua entrada e saída estão tomadas e ninguém pode na entrada dela do mar para a terra lançar os gêneros e materiais dos particulares por não haver lugar.

golpe sofrido pelo tráfico dois anos depois, com a lei de 07 de novembro de 1831, que declarava livres todos os africanos que entrassem no país a partir daquela data e decretava severas punições para os traficantes, resultou na desativação do mercado e em uma forte queda na importação de escravos.

Embora visando desestimular o tráfico transatlântico, essa lei, na verdade, acabou por incrementá-lo na clandestinidade, não raro disfarçado de tráfico interno, interprovincial. Uma forte demanda por escravos vinha das lavouras de café no Vale do Paraíba, que não conseguiam, àquela altura, prescindir dessa força de trabalho. Tanto que foi necessária uma segunda determinação legal, a Lei n 581, de 04 de setembro de 1850, que estabelecia medidas severas de repressão aos traficantes, visando coibir de fato a importação de africanos para serem escravizados. Se ela não foi suficiente para liquidar com o comércio transatlântico - que tentou resistir clandestinamente ainda por mais algum tempo, embora já de todo enfraquecido -, essa lei o desestimulou e inviabilizou economicamente, de tal forma que o negócio negreiro se tornou antilucrativo. $E$, nessa condição, foi finalmente extinto.
13. Diário do Rio de Janeiro, n. 20 , de 26 de março de 1822. Biblioteca Nacional, Rio de Janeiro.

14. Ver Claudio de Paula Honorato (2008).

15. Ver Júlio Cesar Medeiros Pereira (2007).

16. Arquivo Geral da Cidade do Rio de Janeiro. Códice 49-1-5. 


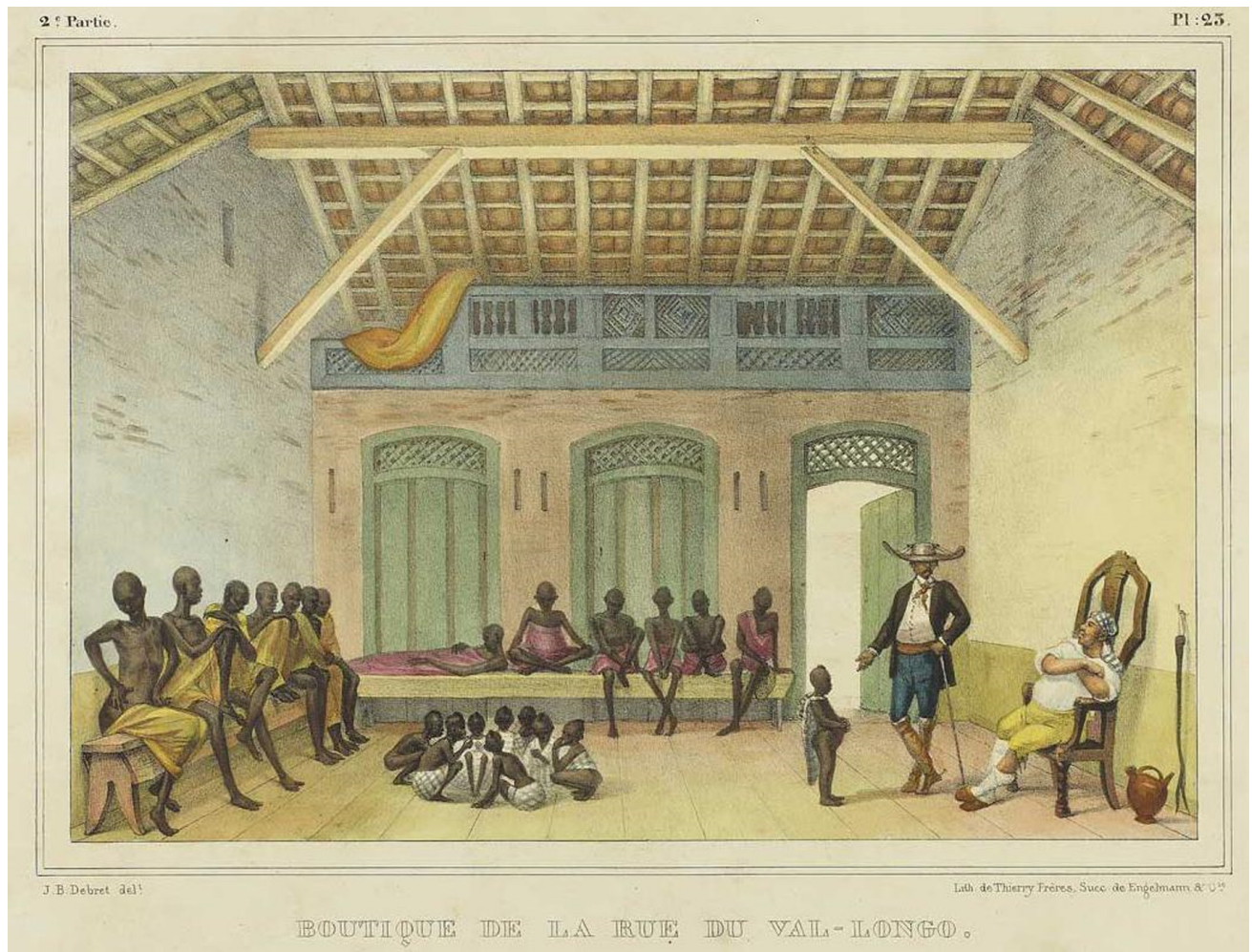

Figura 5 - Mercado de escravos na da rua do Valongo, Debret, c. $1816-1828$.

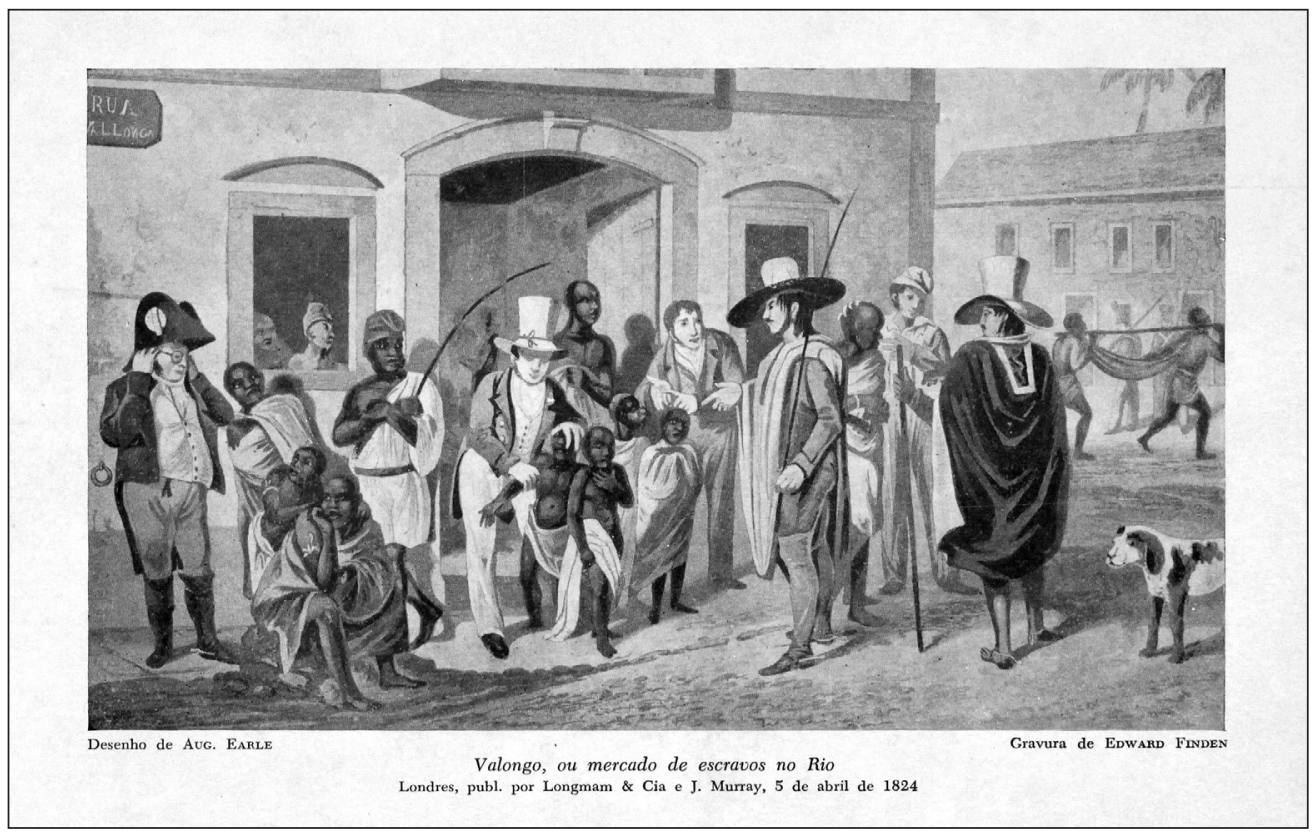

Figura 6 - Rua do Valongo, como consta na placa afixada na casa, no alto à esquerda, com seus armazéns de escravos. Valongo, ou mercado de escravos no Rio. Desenho de Augustus Earle, gravura de Edward Finden, 1824. 
Durante o período conhecido de funcionamento do Cais do Valongo, entre 1811 e 1831, o Rio de Janeiro recebeu cerca de 550 mil africanos para serem escravizados. E entre 1811 e 1842, cerca de 615 mil, com o maior volume na década de 1820 17. Segundo Florentino, o tráfico no Rio de Janeiro foi "o mais importante fluxo de cativos em todo o planeta, entre 1790 e 1830 (sobretudo durante as duas últimas décadas desse período)"18, o que fez dele o principal ponto de entrada das Américas.

A transformação: de Cais do Valongo a Cais da Imperatriz

A única planta encontrada do Cais do Valongo até o momento ${ }^{19}$ é posterior à interdição do comércio de africanos, datando de $1837^{20}$ (Figura 7).

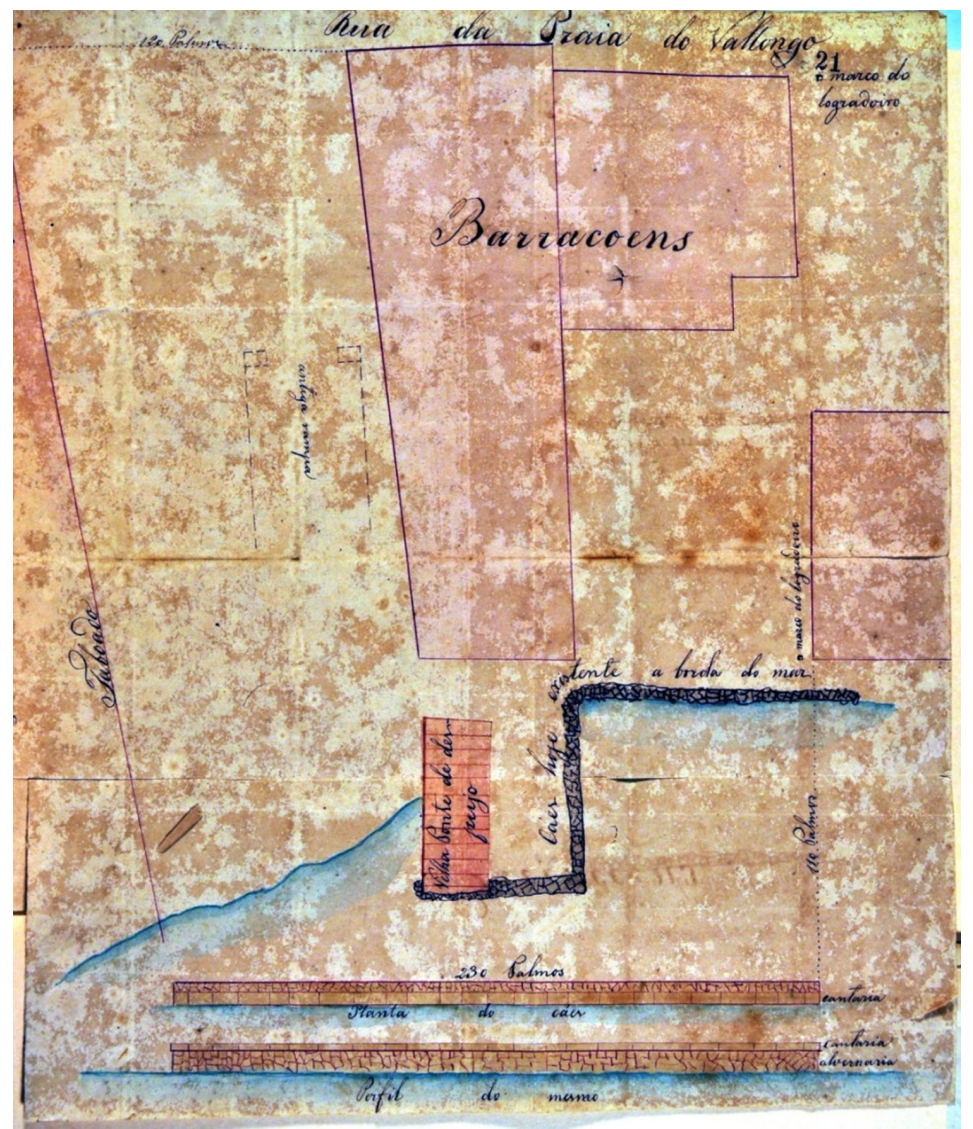

Figura 7 - Planta do Cais do Valongo, 1837. Arquivo Geral da Cidade do Rio de Janeiro.

Nela figuram, à rua da Praia do Valongo, as seguintes construções: "cais hoje existente à borda do mar", "velha ponte de despejo", "taboado", "barracões", além de dois registros do "marco do logradouro". Não é possível saber se os "barracões" representados a essa altura eram remanescentes da época do tráfico para acolher e redistribuir os que chegavam, ou se eram posteriores, destinando-se
17. Ver David Eltis; Martin Halbert (2008).

18 Ver Manolo Florentino (1997, p.11).

19. Planta do Cais do Valongo, Coleção Aforamentos, 1837. Arquivo Geral da Cidade do Rio de Janeiro. Códice 1-2-67.

20. Levantamento histórico feito pelo historiador Carlos Eugênio Líbano Soares, da Universidade Federal da Bahia. 
21. Arquivo Geral da Cidade do Rio de Janeiro. Códice 36.2.1 a outras finalidades. A localização do "taboado" permite supor a existência de uma cobertura sobre a vala de escoamento que existia ali, na antiga área da drenagem natural, que viria a ser descrita dez anos depois, em 1841, como "imunda"21. A "velha ponte de despejo" sugere se tratar de local para descarte de materiais imprestáveis. Ao ser descrita como velha, é a única que permite aventar que existisse há muito tempo. No mais, não é possível atribuir as estruturas representadas e descritas na planta ao cais que funcionou até seis anos antes.

Nos anos que se seguiram à desativação do mercado de escravos, o cais do Valongo continuou funcionando normalmente, voltado para o fluxo de pessoas e mercadorias, até 1843. Nesse ano, por determinação de D. Pedro II, ele foi aterrado e sobre ele foi construído um novo cais para receber a princesa do Reino das Duas Sicílias, Teresa Cristina Maria de Bourbon, que chegava então ao Brasil para seu casamento com o imperador.

Antecipada a maioridade de D. Pedro II, em 1840, sagrado e coroado imperador do Brasil no ano seguinte, aos quinze anos, era chegada a hora de casá-lo. Após malogradas tentativas junto a diferentes cortes europeias de se encontrar uma esposa para ele disposta a vir para os trópicos, finalmente surgiu uma solução no Reino das Duas Sicílias: de comum acordo foi escolhida a princesa Teresa Cristina Maria de Bourbon, filha mais nova do Rei Francisco I de Bourbon e Duas Sicílias e da infanta da Espanha Maria Isabel de Bourbon (Figura 8).

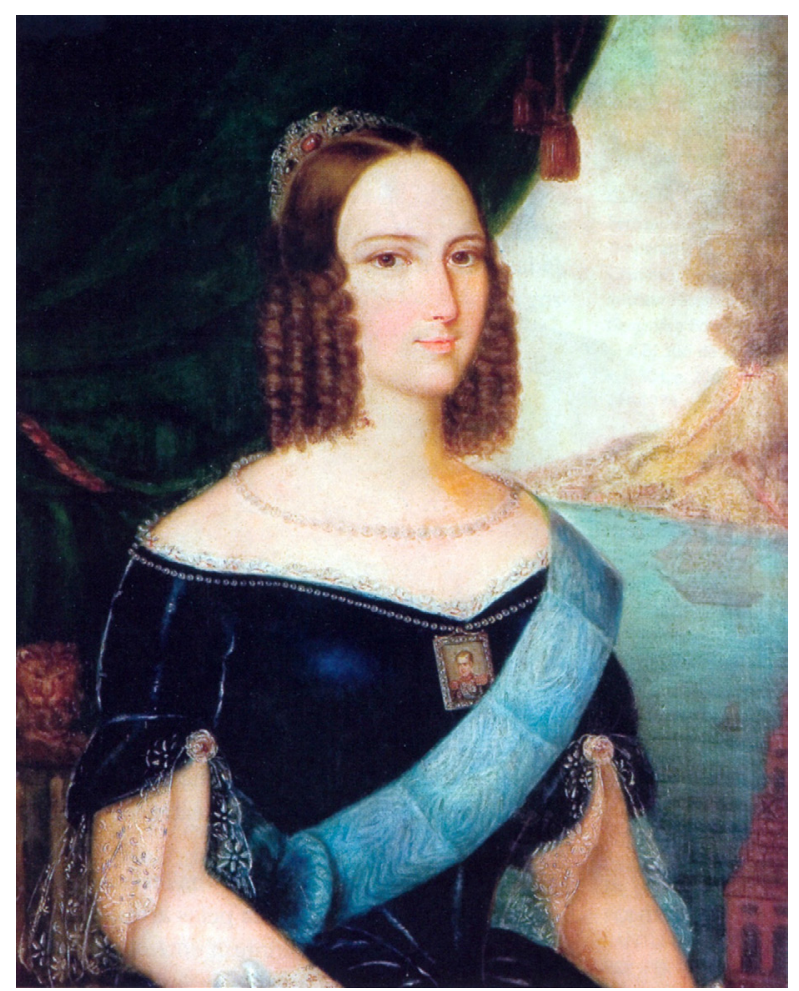

Figura 8 - Retrato idealizado da princesa das Duas Sicílias, Teresa Cristina Maria de Bourbon, com o monte Vesúvio ao fundo, de autoria de José Correia de Lima, c. 1843. Museu Imperial de Petrópolis. 
Arranjado o casamento por meio de contrato assinado em Viena, em 20 de maio de 1842, os noivos casaram-se por procuração na Real Capela Palatina, em Nápoles, em 30 de maio de 1843. Foram iniciados então os preparativos para a vinda da princesa para o Brasil, definindo-se o cerimonial do evento no "Programa para recebimento, desembarque e acompanhamento de Sua Majestade a Imperatriz Teresa Cristina", organizado pela Secretaria de Estado dos Negócios do Império22.

Para recepcioná-la, o ancoradouro defronte ao Terreiro do Paço, em princípio o mais adequado, estava já, àquela altura, em grande parte açoreado, sendo necessário encontrar um novo local para o seu desembarque. Dentre as opções disponíveis ao longo da orla, foi escolhido o Cais do Valongo. Esse foi o desejo expresso pelo imperador em documento encaminhado à Câmara Municipal em 06 de julho de 1843, solicitando que fossem ultimadas as obras naquele cais $^{23}$.

Contudo, tratando-se de uma área degradada da cidade, estigmatizada pelo tráfico de africanos escravizados, era imprescindível dar-lhe uma nova feição. Cumpria proceder a uma profunda reforma que apagasse em definitivo aquela nódoa vergonhosa, tornando a região condigna para receber a Imperatriz do Brasil. $\bigcirc$ projeto dessa reforma tem autoria controvertida. Segundo Gerson ${ }^{24}$, essa tarefa coube a Grandjean de Montigny, integrante da Missão Artística Francesa que veio para o Brasil em 1816 capitaneada por Joachim Lebreton. Aqui chegando, ele se tornou professor de arquitetura da Escola Real de Ciências, Artes e Ofícios, posteriormente transformada, em 1826, na Academia Imperial de Belas Artes; suficientemente qualificado, portanto, para conceber um projeto com requinte compatível com uma princesa de Bourbon, àquela altura já casada por procuração com o imperador do Brasil. Esse projeto incluía, além do cais, a construção de uma praça monumental. Entretanto, não identificamos até o momento fontes primárias que assegurem ser ele de fato o autor do projeto.

Por outro lado, o engenheiro militar Barão Henrique de Beaurepaire Rohan, diretor de Obras Municipais entre 1840 e 1844, foi o autor do primeiro plano diretor de urbanização da cidade, um projeto radical de transformação do seu tecido urbano, contemplando basicamente três aspectos: sanitarização, comodidade e embelezamento. Consta em ofício que the foi encaminhado pela Câmara Municipal, em 26 de setembro de 1842, de acordo com resolução tomada na sessão anterior, do dia 24, a solicitação de que ele deveria apresentar, "com toda urgência, a planta e o orçamento para a obra do Cais do Valongo, que será inspecionada pelo senhor Doutor Luiz Rodrigues Ferreira, devendo-se para esse efeito com V. Sa. entender-se o administrador das Obras". Ocorre que esse documento não deixa claro se Beaurepaire Rohan foi o autor ou tão somente o executor de plano concebido, supostamente, por Grandjean de Montigny.

Ao que se sabe até o momento, a única imagem existente dessa reforma foi produzida por Friedrich Pustkow, em cerca de $1844^{25}$ (Figura 9). Tendo ao fundo uma grande praça, nela aparece, ao centro, uma construção hexagonal com teto abobadado, encimada pela efígie da princesa das Duas Sicílias; o cais, delimitado
22. Manuscritos, 63.05 .006 n. 029. Biblioteca Nacional.

23. Arquivo Geral da Cidade do Rio de Janeiro. Códice 40.2.76.

24. Ver Brasil Gerson (2000, p.152).

25. Segundo Lygia Cunha, "o enigmático" Frederico Pustkow, foi autor, por volta de 1844, de uma série de vistas do Rio de Janeiro litografadas a traço". Cf. Renata Santos; Marcus Venício Ribeiro; Maria de Lourdes Viana Lyra (2010). 
26. Arquivo Geral da Cidade do Rio de Janeiro. Códice 40.2.67, Fl. 47.

27. Arquivo Geral da Cidade do Rio de Janeiro. Códice 40.2.67, Fl. 50 e 54 .

28. Arquivo Geral da Cidade do Rio de Janeiro. Códice 40.2.67, Fl. 48

29. Arquivo Geral da Cidade do Rio de Janeiro. Códice 40.2.67, Fl. 52

30. Arquivo Geral da Cidade do Rio de Janeiro. Códice 40.2.67, Fl. 55 .

31. Arquivo Geral da Cidade do Rio de Janeiro. Códice 40.2.67, Fl. 51.

32. Arquivo Geral da Cidade do Rio de Janeiro. Códice 40.2.67, Fl. 56-57 por um gradil, foi ornado, à entrada, por um par de golfinhos de bronze sobre pilares de pedra. E o velho Cais do Valongo foi rebatizado como Cais da Imperatriz.

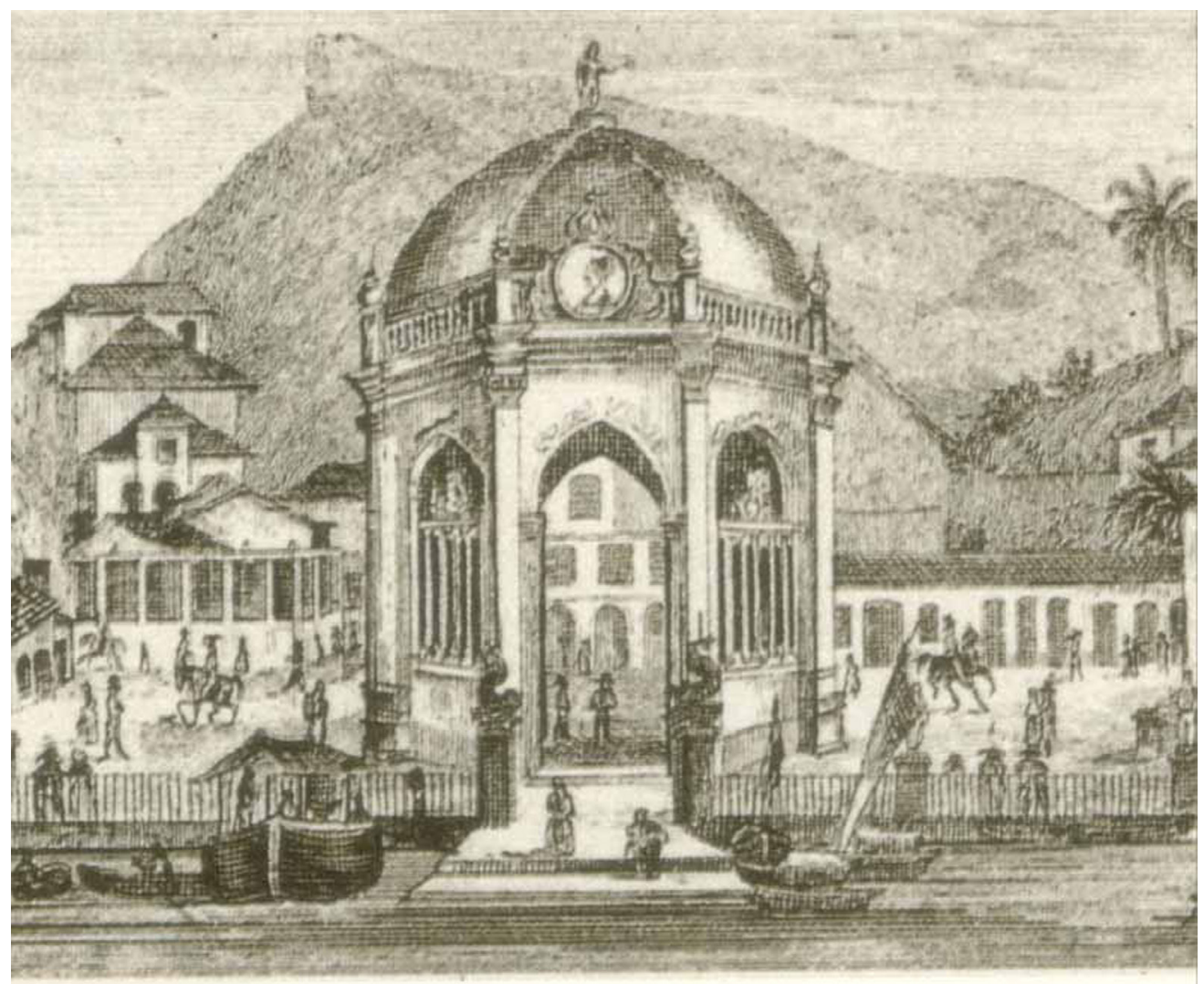

Figura 9 - Cais do Valongo embelezado para o desembarque da Imperatriz, litogravura de autoria de Friedrich Pustkow, cerca de 1844. Biblioteca Estadual do Rio de Janeiro.

No Arquivo Geral da Cidade do Rio de Janeiro há vários processos relativos a pagamentos de carroças de pedra de alvenaria para alinhamento do cais $^{26}$, bem como de inúmeros carretos de cantaria ${ }^{27}$; compra de materiais como cera branca, breu, chumbo em barra ${ }^{28}$, moios de cal29, vergalhões, picões e escodas para lavrar pedra ${ }^{30}$, pedra mármore para letreiro ${ }^{31}$, ferros e braçadeiras para lampiões, bem como azeite de peixe ${ }^{32}$, datados de jutho e agosto de 1843, atestando o trabalho acelerado de remodelamento da área. Contudo, segundo o Diário do Rio de Janeiro de 04 de setembro de 1843, o cais ainda estava em obras no dia da recepção à imperatriz.

A princesa das Duas Sicílias chegou ao Rio de Janeiro, sob salvas de artilharia das "fortalezas do mar e dos vasos de guerra", ao final do dia $\mathrm{O} 3$ de setembro de 1843, a bordo da fragata brasileira Constituição, integrante da frota enviada por D. Pedro II a Nápoles para buscá-la. Trazida no dia seguinte na galeota imperial até o cais rebatizado em sua homenagem como Cais da Imperatriz, a princesa e sua comitiva seguiram em cortejo pela antiga rua do 
Valongo, da mesma forma renominada como rua da Imperatriz, especialmente engalanada para a ocasião. Em seguida, continuaram pela rua Larga de São Joaquim (atual rua Marechal Floriano), Campo da Aclamação (atual Praça da República), e ruas de São Pedro e Direita (atual rua Primeiro de Março) - "bordadas pelas tropas de linha e das guardas nacionais", embandeiradas e iluminadas - até chegar à Capela Imperial (atual lgreja do Carmo), onde o casal recebeu a bênção matrimonial e foram ratificados os votos antes proferidos por procuração ${ }^{33}$.

Após o desembarque da princesa das Duas Sicílias, e ao longo do século XIX, o cais ainda serviu como ponto de atracação por pelo menos mais seis décadas, até ser aterrado para a construção do porto do Rio de Janeiro, no início do século XX, em 1911 . No decorrer desse período, contudo, sua trajetória parece ter sido marcada por uma degradação contínua, a julgar pelos sucessivos e constantes pedidos de reparos nas suas estruturas encaminhados à Câmara Municipal.

Logo após a sua inauguração, foi recomendada, em $\mathrm{Ob}$ de dezembro de 1843, a demolição da construção hexagonal para se proceder ao calçamento da praça ${ }^{34}$. Nesse caso, a litogravura de Pustkow pode ter sido feita anteriormente a essa recomendação, ou logo em seguida. Em junho de 1844, constam reclamos para conserto de estragos no Cais da Imperatriz, "que tornou a abrir em alguns lugares em consequência das grandes marés que apareceram nestes últimos dias" - A construção da frase deixa evidente que isso já ocorrera anteriormente, e a obra foi aprovada no mês seguinte, recomendando-se que suas juntas deveriam ser unidas com "argamassa convenientemente preparada" 36 . Dois meses depois, em setembro, há registro de remessas de mais lajeado para as obras do cais $^{37}$.

Poucos anos depois, em fevereiro de 1847, foram solicitados reparos emergenciais para o Cais da Imperatriz, que se achava "bastante arruinado"38. Em maio de 1853, foram novamente encaminhados pedidos de conserto, tendo a Diretoria de Obras Municipais contratado a colocação de lajes e degraus que faltavam, a fixação dos que se encontravam soltos, o conserto da cantaria, a colocação de grades, bem como o reparo e a pintura das já existentes ${ }^{39}$. Em 1870, foi informado o péssimo estado do cais, arruinado pelo mar e pela atracação constante de embarcações de pequeno porte, sendo relatado que "os saveiros que amiudamente atraca(valm para descarregar o carvão destruíram metade do cais do lado sul, derrubando as grades e a cantaria que o guarneciam" 40 . Em agosto de 1891, foram pedidos novos reparos no cais, mencionando-se a reconstrução das paredes da "parte abatida", sugerindo ter ocorrido ali um desabamento ${ }^{41}$. Três meses depois, foi solicitada verba suplementar para esses consertos, em vista de ter sido necessário "fazer remoção de muitas pedras grandes, que demandaram muitos operários" 42 . Neste último documento, chama a atenção o fato de ele ter sido referido como Cais Municipal, deixando evidente, nos primeiros anos da República, o desejo da eliminação intencional, por parte do novo regime, de qualquer alusão ao Império, no clima fortemente antimonarquista da época.
33. Arquivo Geral da Cidade do Rio de Janeiro. Códice 32.1.43, Fl. 75, de 14 de agosto de 1843 .

34. Arquivo Geral da Cidade do Rio de Janeiro. Códice 36-2-4, Fl.260. Série Ofícios da Câmara Municipal

35. Arquivo Geral da Cidade do Rio de Janeiro. Fundo Câmara Municipal, Série Cais, 40.2.67, Fl. 87.

36. Arquivo Geral da Cidade do Rio de Janeiro. Fundo Câmara Municipal, Série Cais, 40.2.67, Fl. 88.

37. Arquivo Geral da Cidade do Rio de Janeiro. Fundo Câmara Municipal, Série Cais, 40.2.67, F1 89 A 91.

38. Arquivo Geral da Cidade do Rio de Janeiro. Fundo Câmara Municipal, Série Cais, 40.2.67, Fl. 101.

39. Arquivo Geral da Cidade do Rio de Janeiro. Fundo Câmara Municipal, Série Cais, 40.2.67, Fl. 114.

40. Arquivo Geral da Cidade do Rio de Janeiro. Fundo Câmara Municipal, Série Cais, 40.2.67, Fl. 103.

41. Arquivo Geral da Cidade do Rio de Janeiro. Códice 40.3.13 Fl. 71, 72, 89 .

42. Arquivo Geral da Cidade do Rio de Janeiro. Fundo Câmara Municipal, Série Cais, 40.3.13, Fl. 89. 
43. Cf. Henrique de Beaurepaire Rohan (1968).

44. Arquivo Geral da Cidade do Rio de Janeiro. Fundo Câmara Municipal,Série Cais, 40.2.67, Fl.78-79.

45. Arquivo Geral da Cidade do Rio de Janeiro. Fundo Câmara Municipal,Série Cais, 40.2.67, fl. 76-77.

46. Arquivo Geral da Cidade do Rio de Janeiro. Fundo Câmara Municipal, Série Cais, 40.2.67, Fl. 98-99.

\section{A Praça Municipal (atual Praça Jornal do Commercio)}

Por ocasião da reforma para a criação do Cais da Imperatriz, o antes Largo do Valongo ou Praça do Valongo foi renomeado pela Câmara como Praça Municipal. Sobre esse remodelamento, assim se pronunciou o Barão Henrique de Beaurepaire Rohan, então diretor de Obras Municipais, em relatório apresentado rm 1843 à Câmara: "a antiga imunda praia do Valongo acaba de converter-se em uma elegante praça, com a denominação de Municipal, depois da construção do Cais da Imperatriz"43.

Entretanto, algumas evidências permitem supor que essa grande reforma ficou em muitos aspectos inconclusa. No ano seguinte, em fevereiro de 1844, foi feito orçamento para o lajeado "que faltou fazer na Praça da Imperatriz", propondose substituí-lo por calçamento ${ }^{44}$. No Arquivo Geral da Cidade do Rio de Janeiro consta um documento datado de 23 de fevereiro de 1844, relativo à chegada de uma estátua de mármore branco representando Marte, vinda de Gênova e no valor de 400\$000 réis, que deveria substituir uma estátua de gesso ${ }^{45}$. Tratava-se de uma das quatro estátuas das divindades greco-romanas destinadas, no projeto supostamente atribuído a Grandjean de Montigny, ao embelezamento da Praça Municipal, sendo as demais representações de Mercúrio, Minerva e Ceres, que de fato foram instaladas mais tarde. Outra evidência foi a proposta da Câmara, ratificada pelo imperador em agosto de 1843, antes portanto da chegada da imperatriz, de se erigir um monumento comemorativo do seu desembarque, o que só viria a ocorrer muitas décadas mais tarde. Para essa finalidade, deveria ser aproveitado para a sua base o alicerce já construído na praça para receber um chafariz.

Mais que um projeto inconcluso, contudo, a elegância original da praça parece ter sido submetida, com o passar dos anos, ao mesmo processo de degradação progressiva sofrido pelo cais, não obstante os vários esforços empreendidos, sucessivamente, para a sua conservação e revitalização.

Até poucos anos depois da reforma, em fevereiro de 1846, a praça aparentemente ainda mantinha sua dignidade. Foi solicitada à Câmara Municipal a instalação "no Cais da Imperatriz" (na verdade, na Praça Municipal) de "quatro assentos de pedra", à semelhança dos que existiam no cais da Praça dos Mineiros, já que, por falta dessa comodidade, as famílias pouco permaneciam "naquela elegante praça". Os bancos foram colocados quatro meses depois, em junho do mesmo ano ${ }^{46}$.

Em 09 de junho de 1855, a Estrada de Ferro D. Pedro II solicitou licença do governo imperial para "construir cais ou ponte de madeira sobre o mar, bem como levantar barracões na Praça Municipal para desembarque e depósito dos objetos necessários às obras desta estrada". A Câmara Municipal rejeitou o pedido, entendendo ser a referida praça um local "onde a edificação é regular e sob plano, tendo quase em seu centro um chafariz e sobre o mar o melhor cais de embarque e desembarque que se vê em todo o nosso litoral", servindo ainda a praça de mercado 
provisório onde se vem vender legumes, frutas e outros gêneros à população daquelas circunvizinhanças" ${ }^{\prime 7}$. Essa negativa, contudo, não parece ter sido suficiente para deter as intenções da companhia. Em 1870, foi informado o péssimo estado da praça, em decorrência da determinação da Diretoria da Estrada de Ferro de que nela fosse descarregado o carvão de pedra destinado aos seus serviços, que, em contínuo movimento, gerava um pó danoso à saúde ${ }^{48}$. Foi feito um vigoroso protesto popular, entendendo a subdelegacia do Segundo Distrito de Santa Rita que a companhia não tinha o direito de se apossar e, menos ainda, destruir logradouro público destinado à comodidade das pessoas e ao embelezamento da cidade, tendo sido reconhecida a necessidade urgente das obras ${ }^{49}$.

Em junho de 1893, a queixa de um morador sobre o estado de abandono e falta de asseio do outrora Largo da Imperatriz pedia, "a bem da moralidade pública", para remover pedras arrancadas, que tinham virado entulho, bem como impedir o "ajuntamento de vagabundos e imigrantes que praticam obcenidades e pronunciam palavras obcenas" naquele loca ${ }^{50}$. Contudo, uma outra grande reforma só the estaria reservada novamente no início do século XX, por ocasião dos grandes aterros para a construção do Porto do Rio de Janeiro, feitos entre 1904 e 1910.

\section{Chafariz da Praça Municipal}

Em 1840, um juiz de paz na Freguesia de Santa Rita encaminhou requerimento ao Ministério do Império, solicitando licença para construir, com subscrição popular, um chafariz considerado de utilidade pública na Praça do Valongo ${ }^{51}$. Em 26 de novembro de 1842, há registro de um embargo feito na obra de construção desse chafariz, para a qual teria sido necessário derrubar uma barraca de madeira muito velha no local onde ele seria construído, bem como retirar objetos destinados à venda, porém muito deteriorados ${ }^{52}$.

A julgar pela documentação consultada, aparentemente esse chafariz já estavam construído no ano seguinte, em 1843. A Câmara, desejosa de perpetuar a memória do desembarque da Imperatriz Teresa Cristina Maria na Praça Municipal, oferecera ao imperador o desenho de um chafariz monumental feito pelo vereador Luis Rodrigues Ferreira. Essa oferta no entanto foi declinada, tendo sido encarregada de concebê-lo a Academia Imperial de Belas Artes, pela própria Câmara Municipal, em 14 de fevereiro de 1844. A Congregação dos Professores sugeriu um concurso em que fosse apresentada proposta reunindo os dois chafarizes, aproveitando em parte o já existente, em um monumento-chafariz, encimado por uma estátua da Beneficiência. Grandjean de Montigny fez o risco e o detalhamento da obra, aí incluída a descrição do monumento, seu esquema hidráulico, sua simbologia e inscrições. Submetido à aprovação do imperador em 13 de maio do mesmo ano, esse monumento foi por ele aprovado em 19 de junho. Tanto o outro chafariz já existia então, que, para a execução do monumento, foi sugerido o aproveitamento da sua base 5354 .
47. Arquivo Geral da Cidade do Rio de Janeiro. Códice 40.2.73. Fl. 35.

48. Arquivo Geral da Cidade do Rio de Janeiro. Códice 40.2.73. Fl. 103.

49. Arquivo Geral da Cidade do Rio de Janeiro. Códice 40.2.73. Fl. 105-108.

50. Arquivo Geral da Cidade do Rio de Janeiro. Códice 49.1.54., Fl. 1/1v.

51. Manuscritos, Biblioteca Nacional. C-0941, 004, $\mathrm{N}^{\circ}$ 002.

52. Arquivo Geral da Cidade do Rio de Janeiro. Códice 67.1.12.

53. Arquivo Geral da Cidade do Rio de Janeiro. Códice 46.3.26.

54. Ver Pontifícia Universidade Católica do Rio de Janeiro (1979). 
55. Biblioteca Nacional. C-0704, $024 \mathrm{~N}^{\circ} 001$.

56. Biblioteca Nacional. C-0704, $024 \mathrm{~N}^{\circ} 001$.

57. Biblioteca Nacional. C-0449, 045, C-0463, $054 \mathrm{~N}^{\circ}$ 001, C-0465,057,C-0786,068, C-0786,072, C-0797,020, C-0734, 045.

58. Biblioteca Nacional. C-0704, $024 \mathrm{~N}^{\circ} 001$.

59. Ver Pontifícia Universidade Católica do Rio de Janeiro (1979, p. 227).

60. O projeto desse chafariz e seu esquema hidráulico encontra-se reproduzido em Uma cidade em questão I: Grandjean de Montigny e o Rio de Janeiro. Ver Pontifícia Universidade Católica do Rio de Janeiro (1979, p. 227228).

61. Ver Armando de Magalhães Correa (1935).
Outros documentos reforçam a ideia de que àquela altura o chafariz proposto anteriormente já estava implantado no local. Em 1846, começaram a surgir propostas de proprietários e mestres de navios mercantes, bem como do negociante João Alfredo Russel, para encanar com tubulação de chumbo as águas que sobravam do "chafariz da Praça Municipal", o qual "deitava água por bicas de telhas" que escorriam sem proveito pelo chão, para abastecer os navios do cais $^{55}$. Como a água só podia ser apanhada nos chafarizes do Largo do Paço e no Largo do Moura, as embarcações que aportavam no Cais da Imperatriz tinham que carregar água em baldes, o que era tido como vexaminoso. De toda forma, documento da Inspeção Geral de Obras Públicas a esse propósito, datado de março desse mesmo ano, continuou fazendo menção ao outro "chafariz monumental que o governo pretende mandar fazer", sinal de que a essa altura ele continuava sendo apenas uma intenção ${ }^{56}$. Entre 1849 e 1852, há vários requerimentos solicitando penas d'água derivadas do encanamento do chafariz existente ${ }^{57}$. Suas águas excedentes passaram a ser requisitadas também para o abastecimento das embarcações de cabotagem que ancoravam naquela região por conta do cais, para o que foi mais uma vez solicitada àquela mesma instância aprovação para um projeto de encanamento ${ }^{58}$.

Em vista da grandiosidade da obra monumental que se pretendia realizar em honra da imperatriz, seria necessário retificar a Praça Municipal. Jazidas de mármore em São Fidelis, próxima a Campos, no norte do Rio de Janeiro, foram cogitadas como fonte da matéria-prima necessária para o chafariz, mas decidiu-se finalmente encomendá-la na ltália. Contudo, embora a decisão sobre o monumento ainda não tivesse sido tomada, seu modelo foi exibido na Exposição Geral da Academia de Belas Artes, realizada em $1845^{59}$.

Na verdade, o chafariz monumental projetado por Grandjean de Montigny nunca chegou a ser executado, embora a Praça Municipal tenha sido regularizada para recebê-lo ${ }^{60}$. Um outro monumento alternativo, de características distintas, menos grandioso e de menor qualidade artística acabou sendo erguido anos depois, na década de 1870, por um de seus discípulos, o arquiteto das Obras Públicas Francisco Joaquim Bethencourt da Silva: uma coluna circular de granito com caneluras, formada por 91 monolitos sobre pedestal circular também de granito, elevada sobre três degraus. Nessa coluna foram colocadas quatro bicas, que jorravam água em um tanque retangular; encimada por um capitel coríntio, sobre ele foi colocada uma esfera armilar com as três setas que simbolizam o martírio de São Sebastião, padroeiro do Rio de Janeiro, e que compõem as armas da cidade. Esse marco comemorativo da chegada da imperatriz foi inaugurado em 02 de dezembro de $1872^{61}$ e encontra-se até hoje no local, a atual Praça Jornal do Commercio, embora tenham sido retiradas as bicas e o tanque que o compunham originalmente (Figura 10). Na sua base, uma placa ali afixada pela Secretaria Municipal de Cultura informa atualmente o seguinte: "neste local existiu o Cais da Imperatriz. Em 1843, o antigo Cais do Valongo foi alargado e embelezado para receber a futura Imperatriz Teresa Cristina, que chegava para casar com D. Pedro II". 


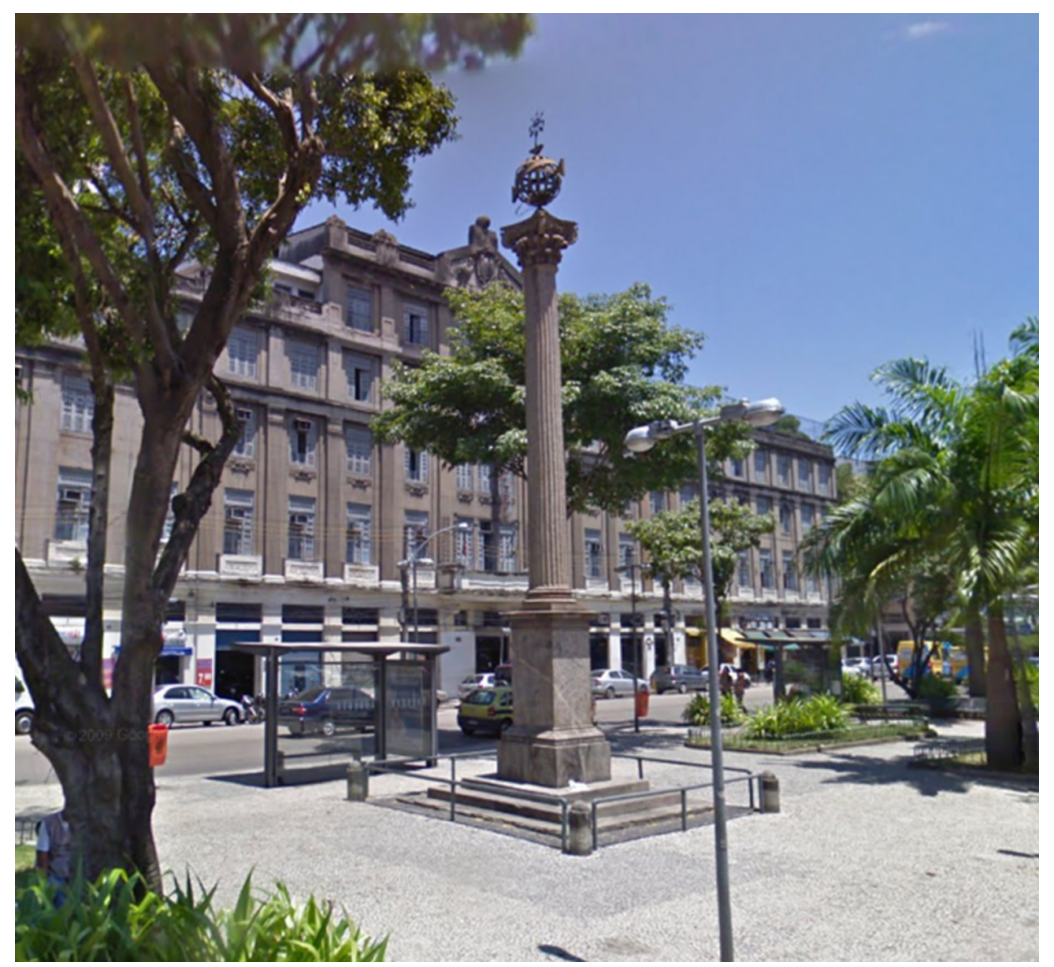

Figura 10 - $\bigcirc$ marco comemorativo do desembarque da Imperatriz Teresa Cristina Maria no cais construído em sua homenagem, originalmente um chafariz com quatro bicas. De autoria de Bethencourt da Silva, foi inaugurado em 1872 na então Praça Municipal, posteriormente Praça Jornal do Commercio. A fotografia, realizada pela equipe do projeto em 2011 , mostra tal como ele se encontrava ao se iniciarem as intervenções arqueológicas.

A oportunidade

Na circunstância do remodelamento da zona portuária da cidade do Rio de Janeiro com vistas a sua revitalização para as Olimpíadas de 2016, foram realizadas pesadas obras de infraestrutura urbana que implicaram intervenções em subsolo. Em virtude da Lei Federal $n^{\circ} 3.924 / 61$, que dispõe sobre os sítios arqueológicos da União, e do Decreto Municipal n²2.872/2003, que cria a obrigatoriedade da pesquisa arqueológica nas obras de intervenção urbana, o Instituto do Patrimônio Histórico e Artístico Nacional recomendou o monitoramento arqueológico de toda a área do empreendimento. A convite dos empreendedores, a Etapa 1 do Programa de Revitalização Urbana da Zona Portuária ficou sob nossa coordenação, compreendendo o trecho entre a Praça Mauá e a Praça Jornal do Commercio. No caso da localização, nesta última praça, dos dois sítios históricos de grande relevância - o Cais do Valongo e o Cais da Imperatriz - apenas o monitoramento arqueológico das intervenções seria não somente uma abordagem inadequada, como insuficiente e equivocada, de tal forma que foi elaborado um projeto de natureza acadêmica, com o objetivo de encontrá-los por meio de escavações sistemáticas. 
62. Para o desenvolvimento da pesquisa arqueológica no Valongo como uma ação sociopolítica, ver Tania Andrade Lima (2013b, p.177204).
Àquela altura não era possível saber se as reformas promovidas na região no início do século XX tinham destruído o Cais da Imperatriz. E se este, por sua vez, ao ser embelezado para receber a princesa Teresa Cristina, tinha eliminado o Cais do Valongo. O projeto, propondo-se a uma ação de resgate do que poderia ter restado tanto de um quanto de outro, tinha no entanto o Cais do Valongo como foco principal. Não se tratava, no caso, de privilegiar um momento histórico em detrimento de outro, mas sim que a realeza se fez suficientemente lembrar - e a coluna que celebra a chegada da Imperatriz Teresa Cristina Maria, até hoje no local, é um testemunho disso - enquanto os africanos que chegaram pelo Valongo para serem escravizados no Brasil foram esquecidos ${ }^{62}$.

Alcançar esse objetivo, contudo, implicava grande desafio metodológico, na medida em que seria preciso conciliar com a pesquisa arqueológica as metas e o apertado cronograma do programa de revitalização, impostos rigorosamente pela Prefeitura do Rio de Janeiro. Dada a relevância dos dois sítios, o procedimento correto, do ponto de vista científico, seria a escavação convencional do trecho da Praça Jornal do Commercio, onde supostamente deveriam estar os dois cais. Contudo, tratava-se de uma intervenção de todo dependente do poder público municipal, posto que implicava o fechamento das duas pistas de uma das principais vias de escoamento do trânsito na zona portuária, a avenida Barão de Tefé (Figuras 11 e 12), bem como o rompimento das suas respectivas camadas de asfalto, o que só poderia ser feito, de fato, pari passu com as obras de infraestrutura em andamento e com o suporte da Prefeitura, que tinha muita pressa. Isso significava abrir mão, em parte, do que era esperado e desejado do ponto de vista científico, em prol do que era possível na circunstância do empreendimento. Ou seja, tão somente monitorar o que fosse emergencial e escavar sistematicamente o que fosse possível. Assim, o trabalho foi iniciado em consonância com a intervenção prevista para as duas pistas de rolamento, no caso, a instalação de um sistema de drenagem de alta capacidade de escoamento de águas pluviais.

Cumpre destacar que o local escolhido para a implantação dessa nova galeria foi precisamente o do antigo canal natural de drenagem que serpenteava pelo talvegue entre os morros da Conceição e do Livramento, coletando as águas do interior e das vertentes das duas elevações e despejando-as no mar. Ou seja, - caminho natural das águas, que corresponde atualmente às ruas Camerino lantiga rua do Valongo, onde estava situado o mercado de escravos, posteriormente rua da Imperatriz), e seu prolongamento hoje em dia, a avenida Barão de Tefé. Obra de caráter emergencial, a galeria de águas pluviais vinha sendo implantada em trecho liberado de monitoramento pelo Iphan, no sentido do porto para dentro, até chegar ao ponto em que o mar alcançava, no século XIX, a atual Praça Jornal do Commercio, na confluência com a rua Coelho e Castro. Quando a equipe de arqueologia foi autorizada a iniciar o trabalho nesse local, em janeiro de 2011 , já havia sido removida a cobertura asfáltica de uma área de 11,50 ×5,10 m, escavada mecanicamente até $1,40 \mathrm{~m}$. 


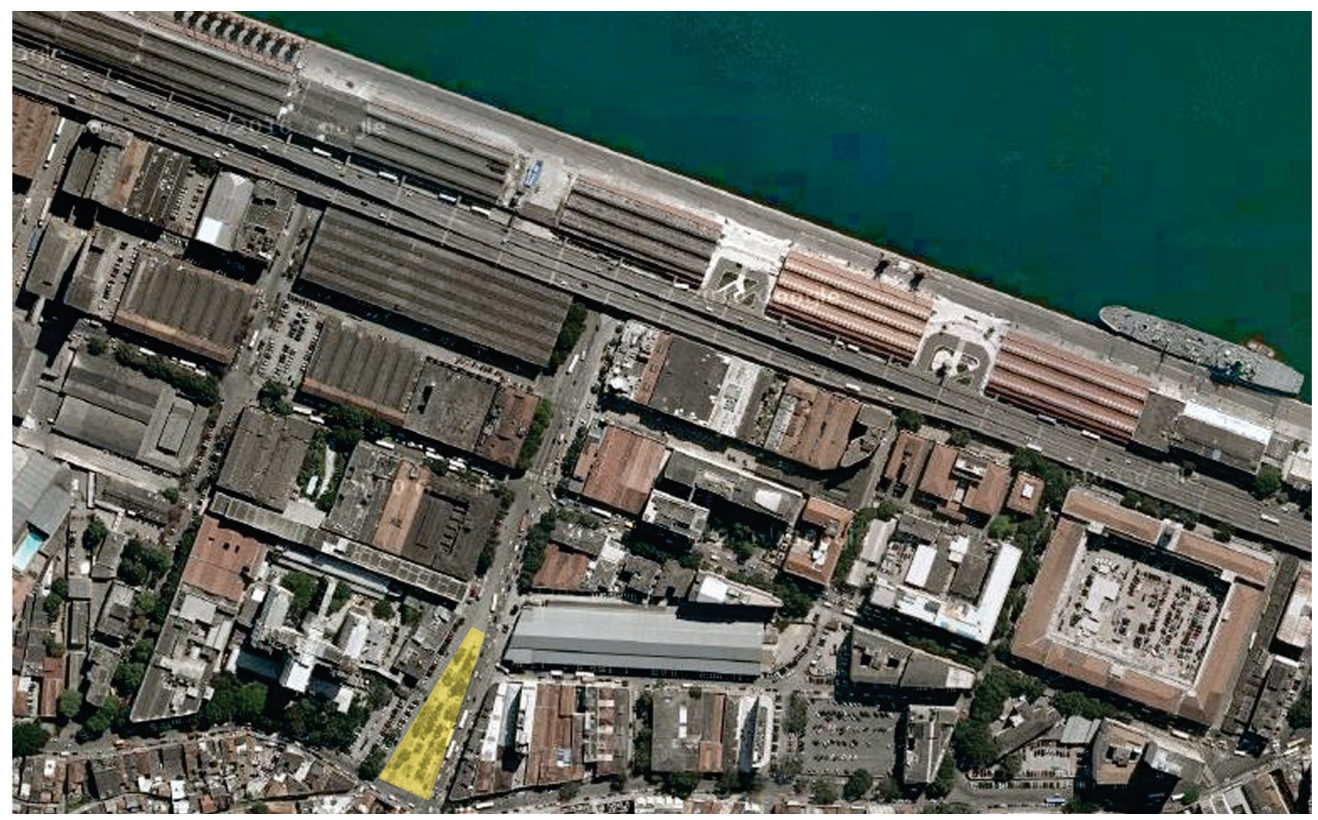

Figura 11 - Em amarelo, a Praça Jornal do Commercio em 2012, cujo formato acompanha o do antigo pontal do Valongo, ladeada pela bifurcação da avenida Barão de Tefé em duas pistas de rolamento. A continuação da pista da direita, na direção oposta ao mar, é a antiga rua do Valongo, posteriormente rua da Imperatriz, e hoje rua Camerino. Ambas são separadas pela rua Sacadura Cabral, a transversal sinuosa que corta a região. No século XIX, o mar chegava até a atual Praça Jornal do Commercio. Mas hoje em dia, em decorrência dos sucessivos aterros feitos no início do século XX para a construção do Porto do Rio de Janeiro, ele foi recuado em cerca de 350 m. Fonte: Google Earth, 2011.

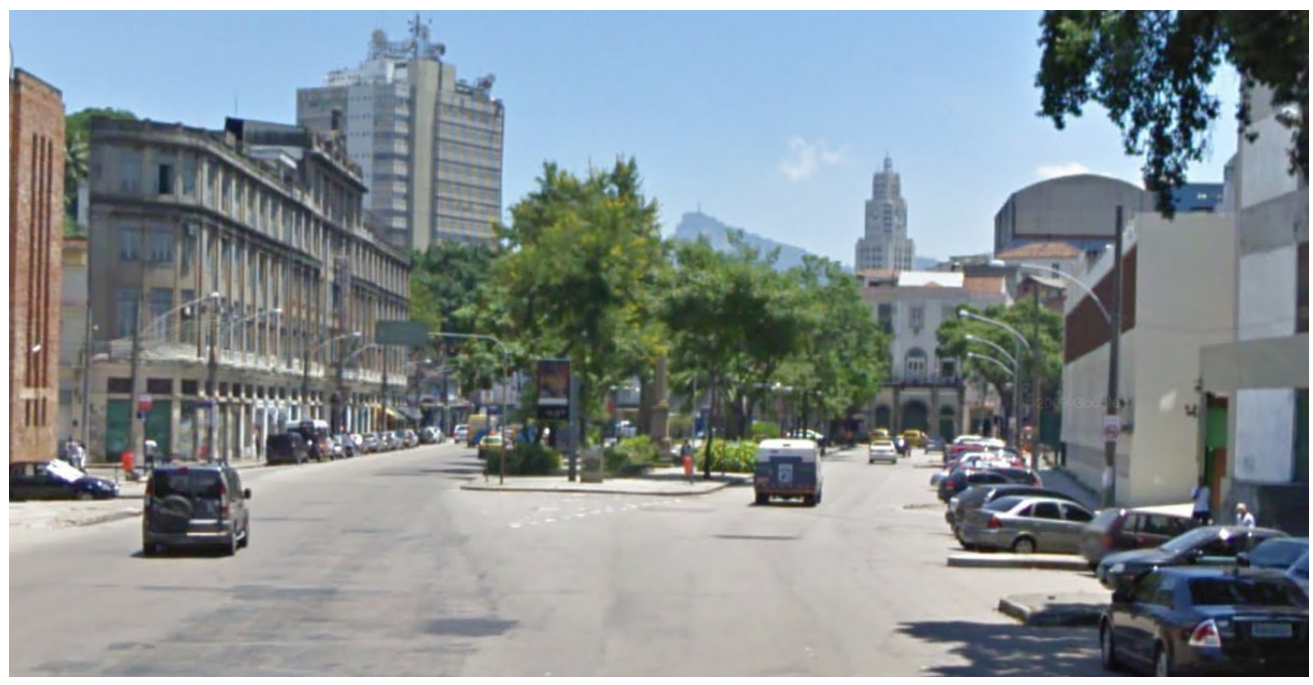

Figura 12 - A extremidade da Praça Jornal do Commercio e a bifurcação da avenida Barão de Tefé em duas pistas de rolamento, previamente ao início das intervenções, em 2011 . À esquerda, a confluência com a rua Coelho e Castro. Nessa foto, feita no sentido sul/norte, a pista da esquerda lao contrário da foto anterior, vista de cima, feita no sentido norte/sul, onde ela está à direita) é a que corresponde ao antigo canal natural de drenagem, continuação da rua Camerino, após o cruzamento com a rua Sacadura Cabral. Fonte: Google Street, 2011.

Annals of Museu Paulista. v. 24. n.1. Jan.-Abr. 2016. 
Os achados

Foi dada, então, continuidade à escavação dessa abertura inicial, aprofundando-a. A partir de 1,85 m, foram encontrados os primeiros vestígios do que se supôs ser o Cais da Imperatriz, no caso, lajotas de pedra de diferentes dimensões, arrematadas por blocos também de diferentes dimensões posicionados verticalmente, formando uma borda. Saindo dessa estrutura foi observado um segmento de tubo de ferro, com cerca de 0,40 m de diâmetro, parcialmente submerso. A partir de 1,0 m de profundidade, a água do lençol freático, somada à subida do nível do mar na maré alta, alagava a área de escavação, dificultando o trabalho e a observação de vestígios arqueológicos. Foi iniciado o bombeamento de água para facilitar o andamento dos trabalhos (Figuras 13).

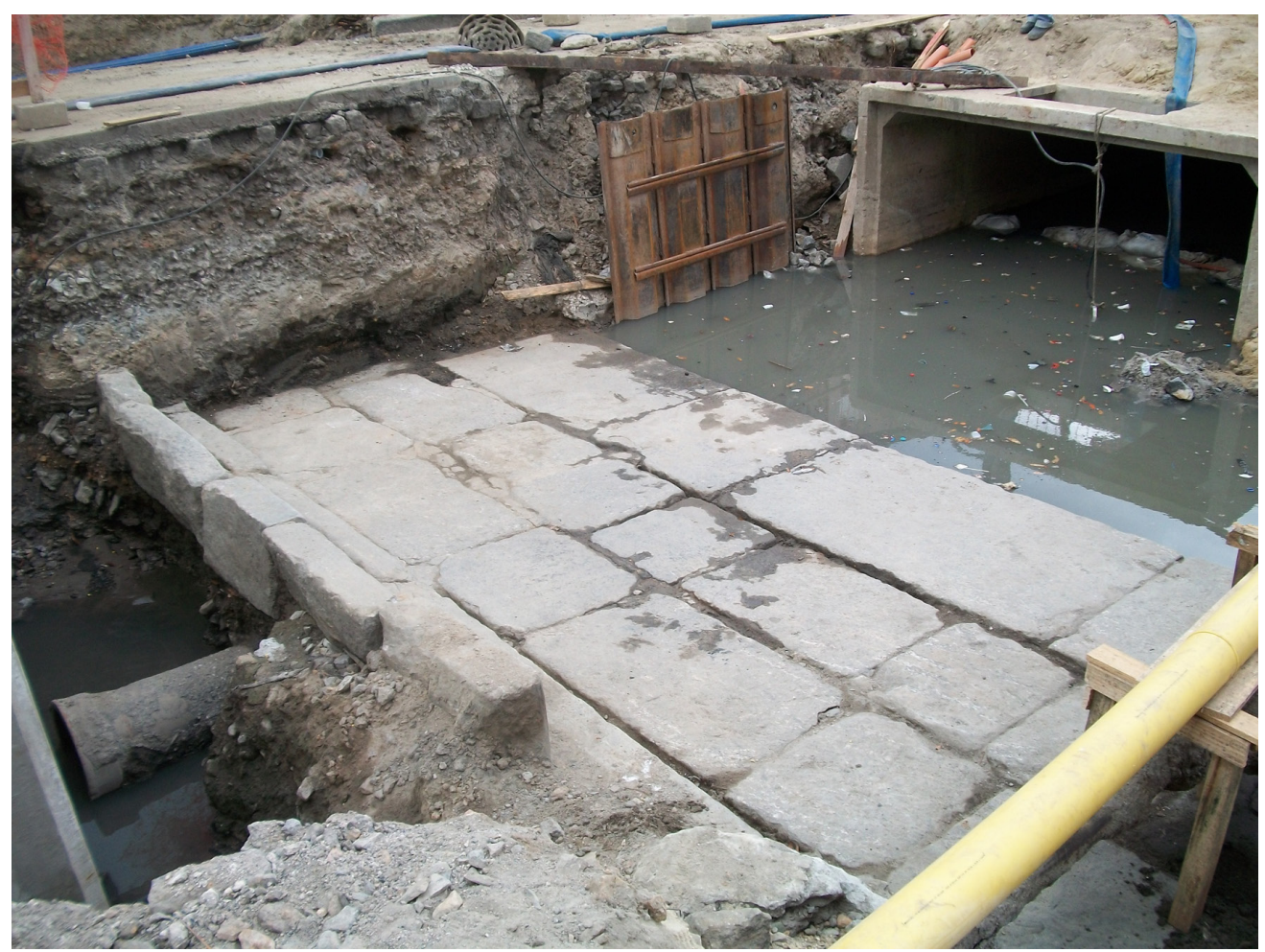

Figura 13 - Os primeiros vestígios encontrados, uma superfície de lajotas de pedra atribuídas tentativamente ao Cais da Imperatriz, vendo-se à esquerda o tubo de ferro que saía dessa estrutura, parcialmente submerso no lençol freático.

Em seguida a essa abertura, foi demarcada uma trincheira ao longo da pista esquerda da avenida Barão de Tefé, no sentido da rua Sacadura Cabral, para dar continuidade à implantação das aduelas de concreto que comporiam a galeria de águas pluviais (Figura 14). Para fins metodológicos e de controle do material arqueológico recuperado nessa grande trincheira escavada mecanicamente, ela foi designada como Frente 1. 


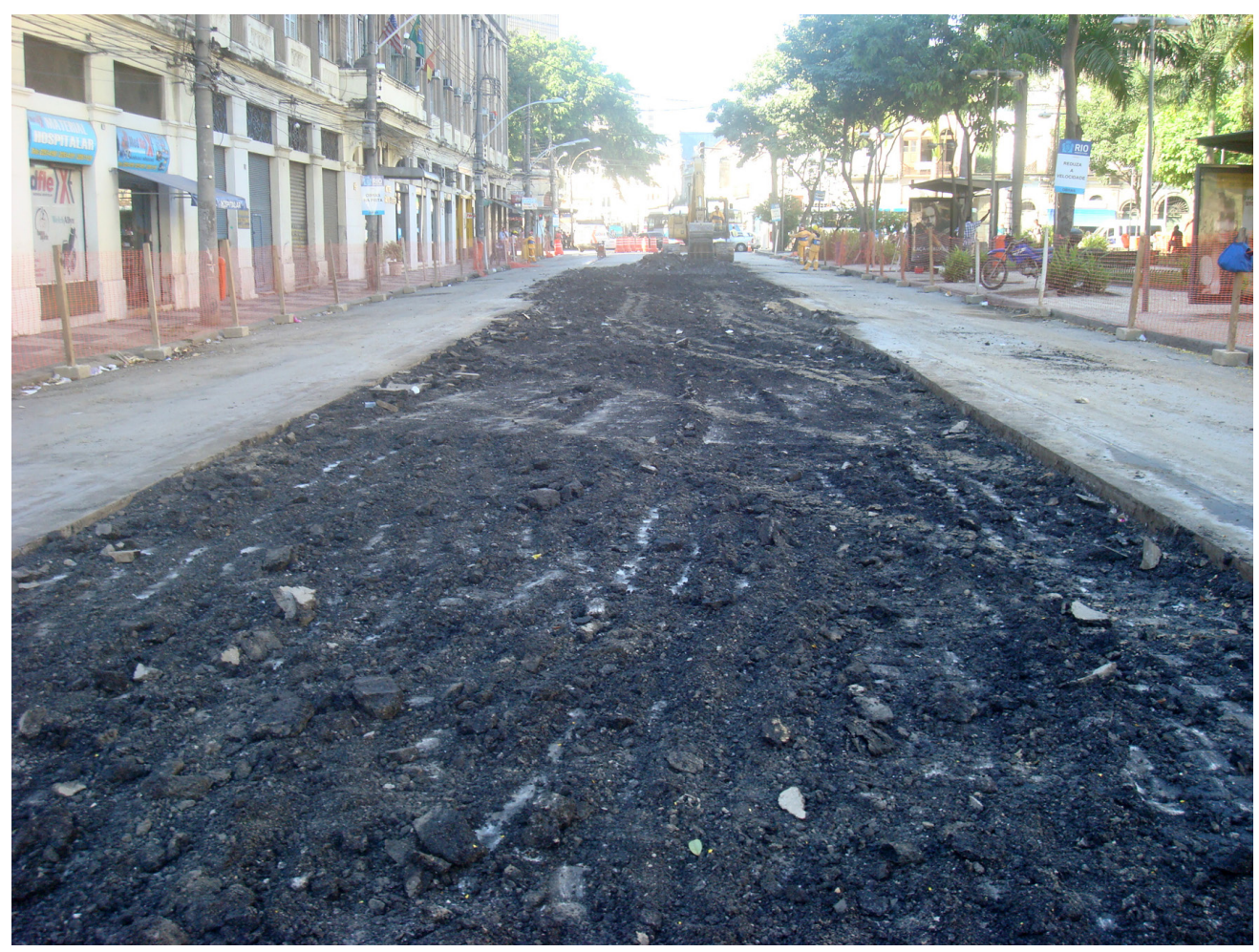

Figura 14 - Trincheira demarcada para escavação mecânica ao longo da pista esquerda da avenida Barão de Tefé, no sentido da rua Sacadura Cabral, para implantação da galeria de águas pluviais.

A Frente 1

Essa trincheira, escavada mecanicamente, foi subdidivida em trechos, considerando-se Trecho 1 aquele onde foram encontradas as lajotas de pedra do suposto Cais da Imperatriz. Com largura aproximada de 5,50 m, essa trincheira, que atingiu em média 3,0 m de profundidade, foi subdividida pela equipe de arqueologia em trechos também de cerca de 5,50 m de extensão, gerando unidades de escavação de aproximadamente 5,50 × 5,50 m, dispostas em sucessão, do Trecho 1 ao 15, ao longo de 87,0 m. Essa medida não foi determinada de forma arbitrária, mas estabelecida a partir das dimensões da blindagem metálica implantada previamente para viabilizar a colocação das aduelas de concreto de seção retangular, que compuseram a galeria de águas pluviais (Figuras 15 e 16).

Ao final do Trecho 1, foi encontrada a outra extremidade do tubo de ferro, de 0,40 m de diâmetro. Entre os Trechos 2 e 4, foi observada a seguinte estratigrafia: logo abaixo do asfalto, camada 1, composta por sedimento arenolamoso, com coloração marrom clara e manchas alaranjadas, fragmentos de rochas, tijolos e telhas, sem vestígios arqueológicos, desde a superfície até 2,00 m de profundidade, típica de aterro. Camada 2: em nível mais profundo, entre 2,0 
e 3,0 m, apareceu uma camada de sedimento areno-lamoso, heterogêneo, de coloração marrom muito escuro, com presença de fibras vegetais de Attalea funifera (piaçava), e forte concentração de vestígios arqueológicos. Os materiais arqueológicos que não foram identificados visualmente durante a escavação, ou mesmo por vistoria posterior à coleta dos sedimentos, foi encaminhado para peneiramento, em razão da altíssima fertilidade arqueológica dessa camada.
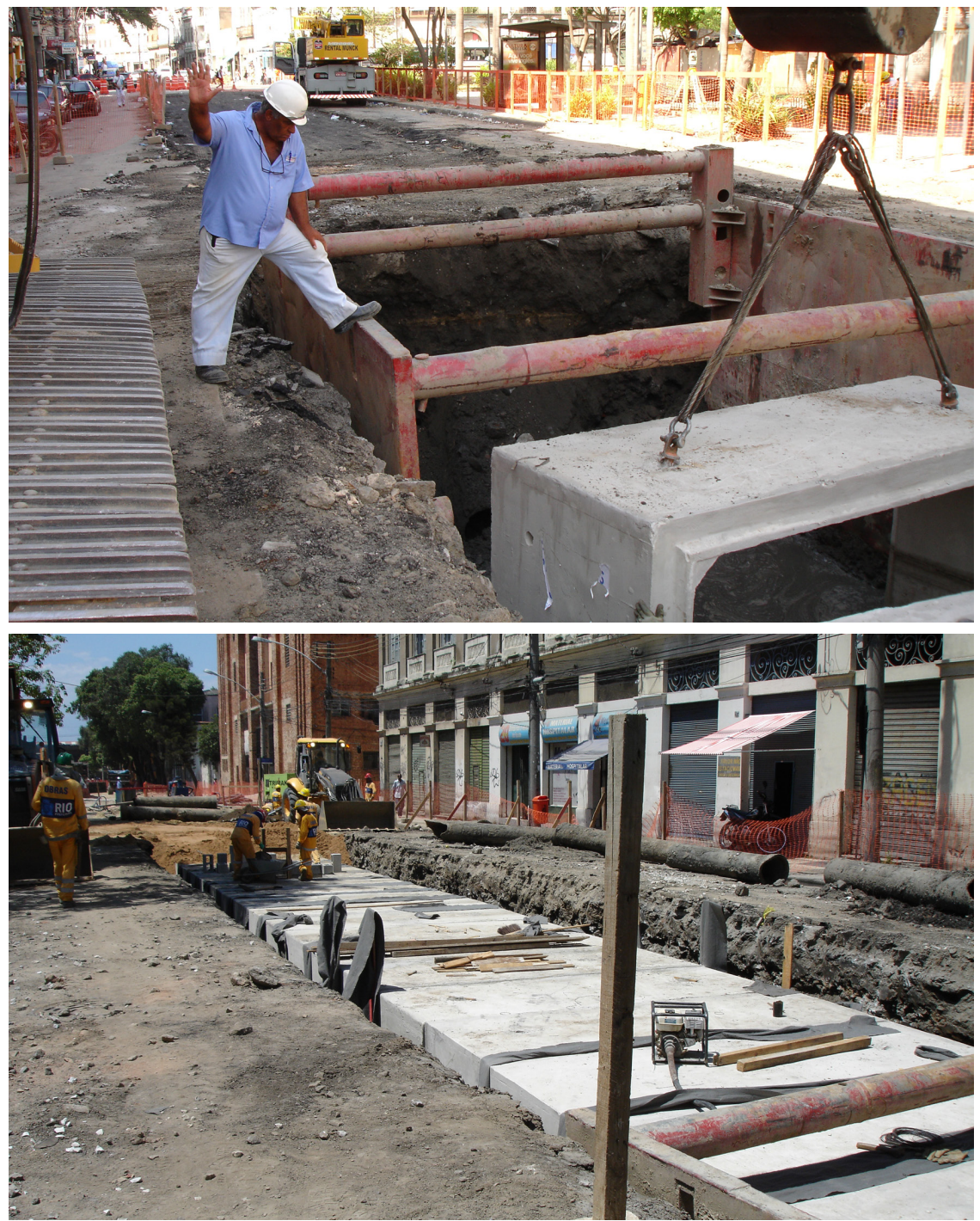

Figuras 15 e 16 - Escavação progressiva da galeria de águas pluviais e escoramento com blindagem metálica para implantação das aduelas de concreto ao longo da trincheira da galeria de águas pluviais - Frente 1 .

De modo geral, os Trechos de 5 a 12 apresentaram um comportamento estratigráfico bastante similar, diferindo apenas na profundidade da última camada, que foi se tornando mais rasa a partir do Trecho 10. A estratigrafia desses trechos pode ser assim sumarizada: camada asfáltica $(0-0,15 \mathrm{~m})$, seguida por uma camada composta 
por paralelepípedos $(0,15-0,30 \mathrm{~m})$; camada de solo característica de aterro, arenolamosa, heterogênea, de cor acastanhada (0,30-2,00 m). Seguiu-se uma camada composta por sedimento lamo-arenoso, castanho escuro, com abundância de material orgânico, até o nível fixado para as escavações da galeria, em 3,0 m de profundidade. Essa camada apresentou, conforme mencionado acima, altíssima densidade de vestígios arqueológicos, com maior concentração ainda nesses segmentos. Entre os Trechos 5 e 9, ela apareceu a uma profundidade de 2,00. No Trecho 10, tornou-se subitamente mais rasa e com um ligeiro aclive em direção à rua Sacadura Cabral. Na parede sul, estava em 1,90 m, e, na parede norte, em 1,60 m de profundidade. Entre os Trechos 12 e 14, essa camada de alta fertilidade arqueológica surgiv entre 1,60 e 3,0 m de profundidade (Figura 17). Ela parecia ser mais profunda, mas a escavação ao longo de toda a trincheira obedeceu ao limite estabelecido pela engenharia para a implantação da drenagem, sempre em 3,0 de profundidade, não tendo sido permitido à equipe de arqueologia aprofundá-la, para não comprometer o trabalho de implantação das aduelas. Os sedimentos resultantes das escavações desses trechos foram vistoriados para coleta dos materiais de maior visibilidade e encaminhados para peneiramento, para que fossem resgatados os de pequenas dimensões.

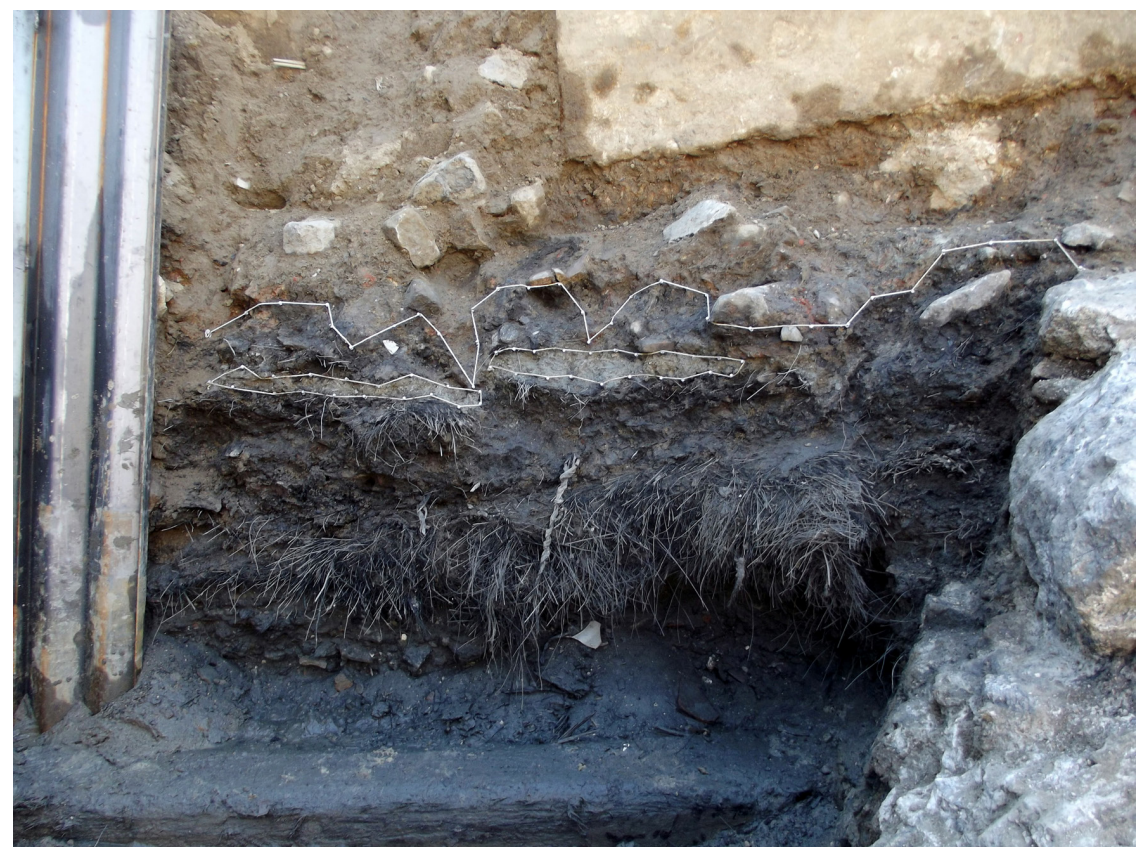

Figura 17 - Segmento do perfil estratigráfico do Trecho 14, vendo-se no nível inferior, entre 2,0 e 3,0 m de profundidade, a camada de sedimento lamo-arenoso castanho escuro, com presença abundante de fibras vegetais de Attalea funifera (piaçava) e forte concentração de vestígios arqueológicos.

Ao longo desses trechos continuaram sendo encontrados tubos de ferro iguais ao do Trecho 1, agora em conexão, tratando-se de parte de um sistema de esgoto implantado pioneiramente no Rio de Janeiro, na década de 1870, pela The Rio de Janeiro City Improvements Company Ltd. Colocados no contato com a 
63. Arquivo Geral da Cidade do Rio de Janeiro. Códice 36.2.1, Fl. 163.

64. Arquivo Geral da Cidade do Rio de Janeiro. Códice 36.2.1, Fl. 167. camada escura, de alta fertilidade arqueológica, os tubos mediram 5,50 m de comprimento e $0.40 \mathrm{~m}$ de diâmetro. Traziam impressa a marca R. M. Co., provavelmente britânica, alguns apresentando também as iniciais O.P.C.B seguidas de um número (300, 400 ou 500).

A escavação do último segmento dessa galeria, o Trecho 15, atingiu a complicada interseção da avenida Barão de Tefé com as ruas Camerino e a transversal Sacadura Cabral, onde inúmeras redes se entrecruzavam em subsolo, em meio a um emaranhado de estruturas, entre elas um vigoroso alicerce de pedra transversal à galeria. Nesse ponto, a tubulação de ferro se conectava a uma válvula com a inscrição Glenfield Co. Limited Kilmarnock. Uma das maiores empresas fabricantes de válvulas do mundo, localizada em Kilmarnock, Escócia, ela foi fundada em 1852, e teve seu período de maior expansão entre 1871 e 1904.

A implantação desse sistema de esgoto era decorrente de um quadro de insalubridade generalizada à época. Em meados do século XIX, as péssimas condições sanitárias reinantes, com a população assolada por graves morbidades e sucessivos surtos epidêmicos, requeriam providências emergenciais. Suja, sem condições mínimas de higiene e sem saneamento básico, a cidade - que se expandira em meio a pântanos e lagoas, com ruas estreitas e mal ventiladas - era ainda frequentemente alagada por ocasião de fortes chuvas que não encontravam escoamento, produzindo um ambiente úmido e insalubre. Na área do Valongo, as condições não eram diferentes. Em março de 1841, a Câmara Municipal solicitou orçamento para os seguintes serviços:

$\left.1^{\circ}\right)$ A construção de duas pequenas pontes sobre o mar, uma correspondendo ao beco que faz a continuação do da [sic] Pedra do Sal, e outra ao (...) da Praia do Valongo, defronte das escadinhas, a fim de que pelas ditas pontes se façam os despejos bem ao mar.

$2^{\circ}$ ) Tapar vala imunda que existe junto do denominado cais do Valongo, dispondo convenientemente o lugar para o fácil escoamento das águas, e

$\left.3^{\circ}\right)$ finalmente para o calçamento do lugar denominado cais do Valongo, a fim de evitar-se o lameiro que ali se faz com as chuvas ${ }^{63}$.

Poucos dias depois, ela dirigiu ofício ao fiscal da freguesia de Santa Rita, à qual pertencia essa área, ordenando que "fizesse cessar [o quanto antes] os despejos que se fazem no chamado Cais do Valongo, determinando que se façam na praia correspondente ao beco das escadinhas e da Pedra do Sal"64.

É importante destacar o segundo item, que menciona a "vala imunda" junto ao Valongo (grifo nosso). Trata-se precisamente do local onde, ao longo da pista da avenida Barão de Tefé, foi encontrada quantidade excepcional de vestígios arqueológicos acumulados e atribuídos ao período de funcionamento do Cais do Valongo, como resultado de descartes contínuos nessa área, que the era adjacente.

Tal como já apontado, era por ali que anteriormente as águas provenientes dos morros da Conceição e do Livramento e também da drenagem de parte da área central da cidade escoavam, configurando um antigo canal natural, visível na forma de uma linha sinuosa na documentação cartográfica de 
séculos anteriores. $\bigcirc$ vigoroso alicerce mencionado acima decerto obstaculizou o escoadouro de águas pluviais, criando-se uma área de despejo de toda sorte de materiais, provavelmente fétida, à semelhança dos "valões" que podem ser observados atualmente em periferias de áreas urbanas. Os serviços requisitados pela Câmara Municipal determinavam facilitar o escoamento das águas, precisamente, por ali, um caminho natural para elas, e assim atenuar as condições de absoluta insalubridade daquela área.

Para tentar sanar o problema, o imperador D. Pedro II abriu, em 1853, uma concorrência para a implantação de um sistema de esgotamento sanitário, vencida por dois sócios que transferiram a concessão para a empresa The Rio de Janeiro City Improvements Company, de capital inglês, em maio de 186365. Edward Gotto, engenheiro inglês, foi o autor do projeto de saneamento, feito a partir de levantamento realizado em 1866 sob sua direção, e também do mapa publicado em 1871, intitulado Plan of the City of Rio de Janeiro 66 (Figura 18). Seu projeto fez do Rio de Janeiro a segunda capital, depois de Londres (1815), e a terceira cidade, depois de Londres e Hamburgo (1842), a receber um sistema de esgotamento sanitário.

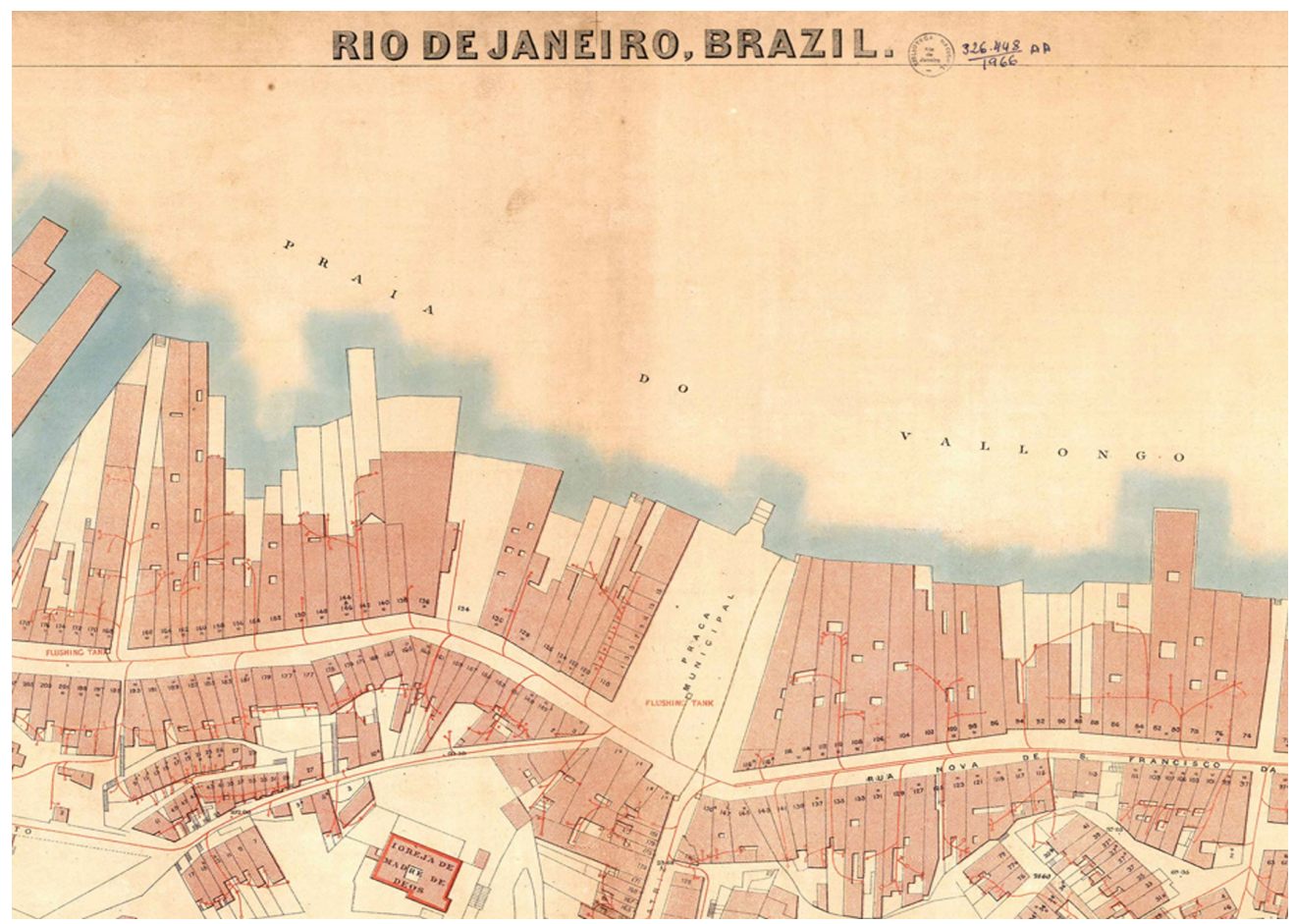

Figura 18 - A planta de Edward Gotto, em nove folhas, mostra em detalhe o trajeto das tubulações na área que receberia o sistema de esgotamento, no centro da cidade. Na folha 5, aqui reproduzida parcialmente, pode ser visto o seu traçado ao longo da Praça Municipal (no centro da figura), tal como de fato foi encontrado nas escavações, desaguando no mar. Da mesma forma, figura na planta uma tubulação até o chafariz da praça, indicado como um flushing tank. Constata-se nesse mapa que àquela altura, em 1871, existia de fato apenas esse chafariz, o que mais uma vez confirma a inexistência do outro, de caráter monumental, que se queria dedicar à Imperatriz. Tampouco a coluna comemorativa com as quatro bicas havia sido erguida a esse tempo.
65. Ver Eduardo Cesar Marques (1995, p.51-67).

66. Ver Edward Gotto (1871). 
Paralela e simultaneamente ao início da escavação da trincheira correspondente à Frente 1, na altura da rua Coelho e Castro, foi cortado o asfalto para abertura de uma outra trincheira na pista oposta da avenida Barão de Tefé, à direita, medindo $6,0 \times 1,0$ m. A ampliação da escavação nesse ponto permitiu uma melhor compreensão da estratigrafia, que expôs uma cobertura asfáltica com aproximadamente $0,15 \mathrm{~m}$, seguida de uma camada de aterro bastante espessa, que chegou a uma profundidade de 1,60 m. Aí foi encontrado outro segmento das lajotas de pedra, semelhante ao encontrado no Trecho 1, atribuído tentativamente ao Cais da Imperatriz (Figura 19).

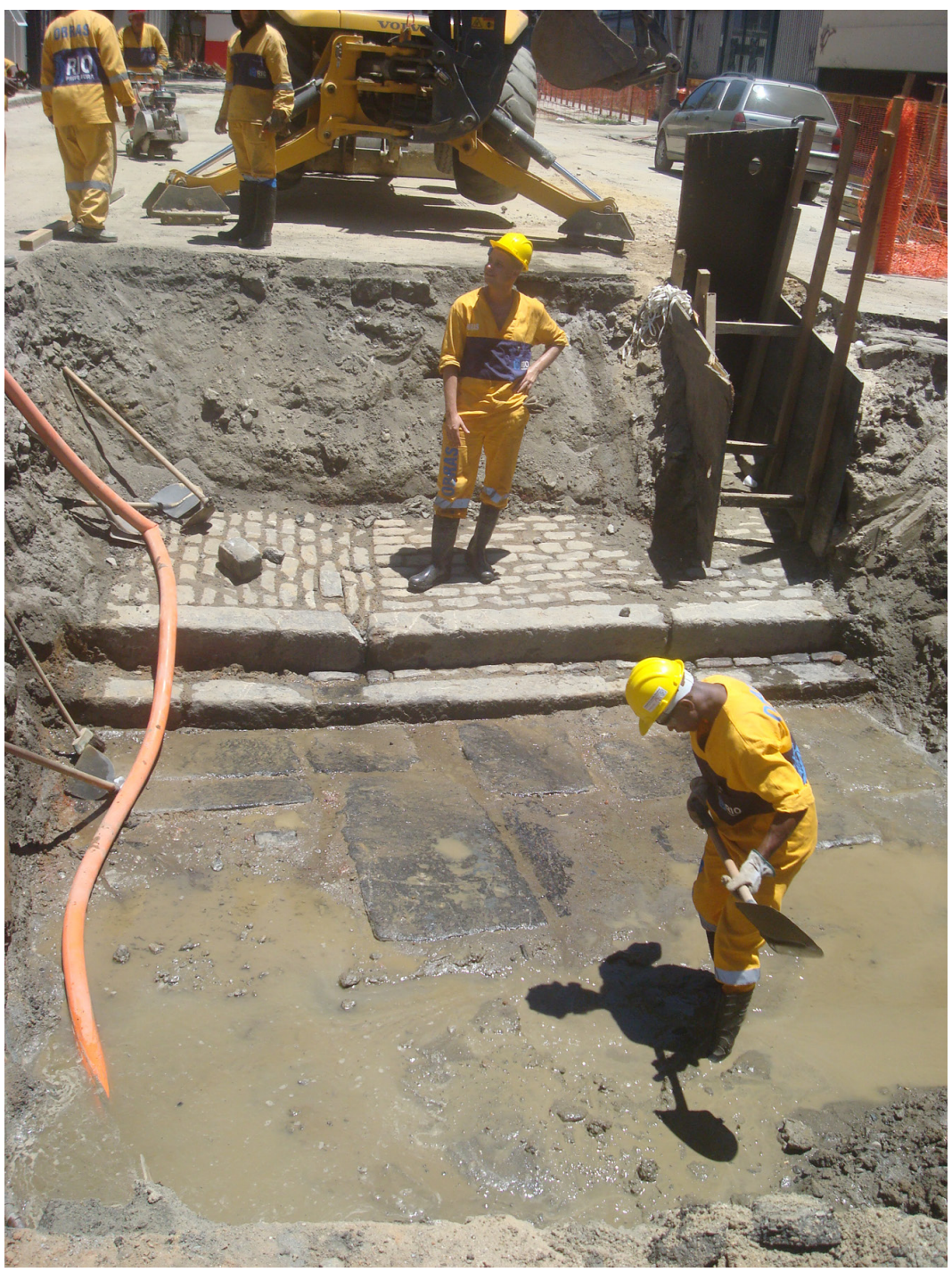

Figura 19 - O surgimento das lajotas de pedra do Cais da Imperatriz, e, acima delas, o calçamento de paralelos atribuído também a ele. 
A montante das lajotas surgiram dois degraus formados por blocos de pedra posicionados verticalmente, e paralelepípedos. Adjacentes a eles, os paralelos foram assentados com uma configuração geométrica, parte no sentido noroeste/sudeste, parte no sentido sudoeste/nordeste. Da mesma forma, esse calçamento foi atribuído ao Cais da Imperatriz, não só por se configurar como uma continuidade em relação às lajotas de pedra do cais, mas porque esse tipo de calçamento surgiu mais tardiamente na área urbana do Rio de Janeiro, não sendo possível atribuílo ao período de funcionamento do Valongo (Figura 20).

A continuidade das escavações feitas no Trecho 2 mostrou que o calçamento de paralelos atribuído ao Cais da Imperatriz foi interrompido em sentido diagonal, o que permitiu que elas fossem aprofundadas em busca do Cais do Valongo. E de fato, a 0,60 m abaixo dos paralelos, começou a surgir um outro calçamento, feito de pedras irregulares, sugerindo se tratar de pé de moleque (Figura 20). Em meio às pedras, foi achado um fragmento de cachimbo de cerâmica escura. Havia sido encontrado o Valongo.

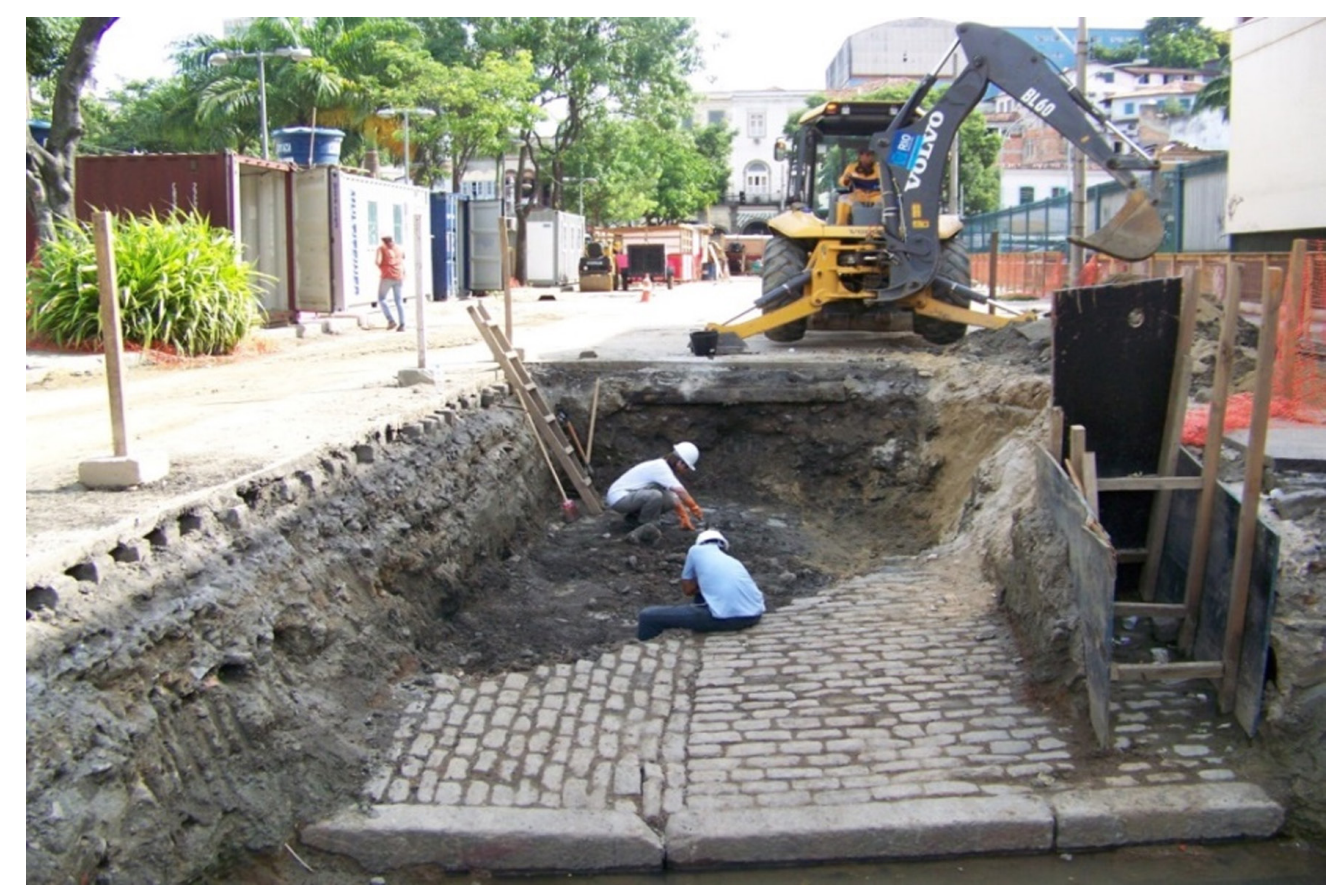

Figura 20 - $O$ corte em diagonal feito nos paralelos, no passado, que permitiu o aprofundamento da escavação e o achado do calçamento do Cais do Valongo.

A partir desse ponto, foram feitas dezenas de sondagens para exame da estratigrafia e detecção da possível ocorrência dos calçamentos do Cais do Valongo e do Cais da Imperatriz no subsolo. Para fins de maior controle, essa frente foi subdividida nas áreas Sul, Norte e Oeste, tendo as siglas das sondagens aí realizadas incorporado essa orientação. Na área Sul, foram demarcadas 26; na Norte, 20; e na Oeste, 48. As sondagens, uma vez tendo proporcionado uma 
67. Para um maior detalhamento da estratigrafia e do conteúdo dos cortes feitos na Frente 2, ver Relatório "Cais do Valongo/ Cais da Imperatriz". Caderno com 111 pranchas, janeiro de 2013, depositado na Superintendência do Iphan no Rio de Janeiro. boa compreensão do comportamento estratigráfico e deposicional, não justificavam mais a abertura de novos cortes, razão pela qual eles foram posteriormente unificados em trincheiras e/ou transformados em escavações em área ampla, para um melhor entendimento da organização do espaço (Figuras 21 a 24). Algumas não foram escavadas em sua totalidade, por conterem remanescentes do Cais da Imperatriz, tendo a escavação se aprofundado apenas até o esse nível, preservandose seu calçamento. $\bigcirc$ do Cais do Valongo não foi observado apenas em alguns poucos cortes; onde ele foi encontrado, suas profundidades variaram de acordo com o aclive em direção à rua Sacadura Cabral, desde 1.80m a 1,0 m67.

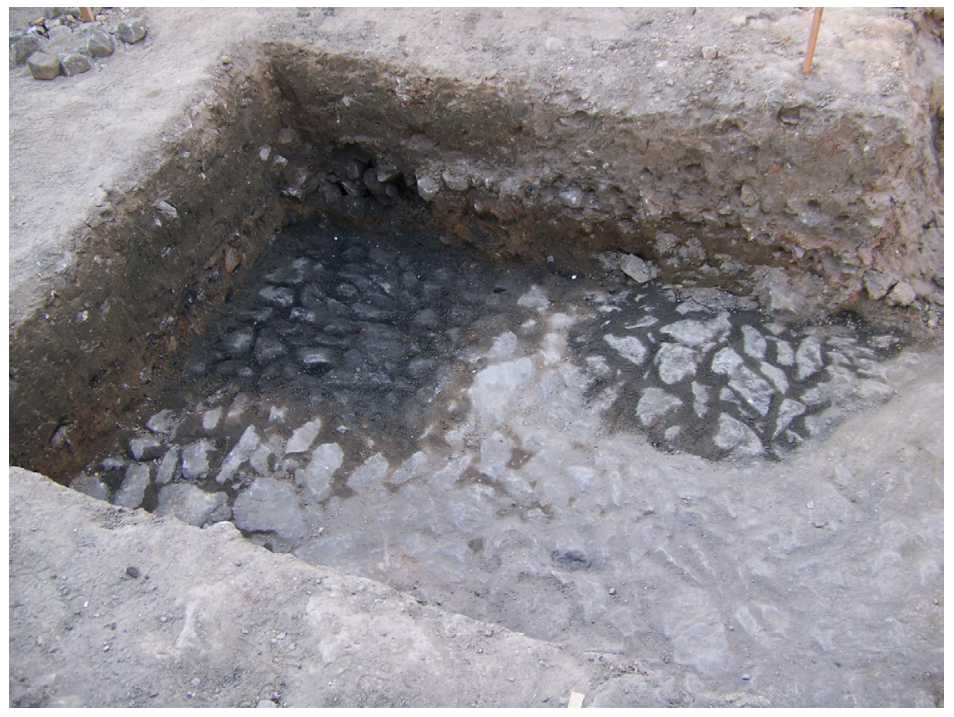

Figura 21 - Exposição do calçamento do Cais do Valongo. Nas sondagens iniciais da Frente 2 não havia presença do calçamento do Cais da Imperatriz.

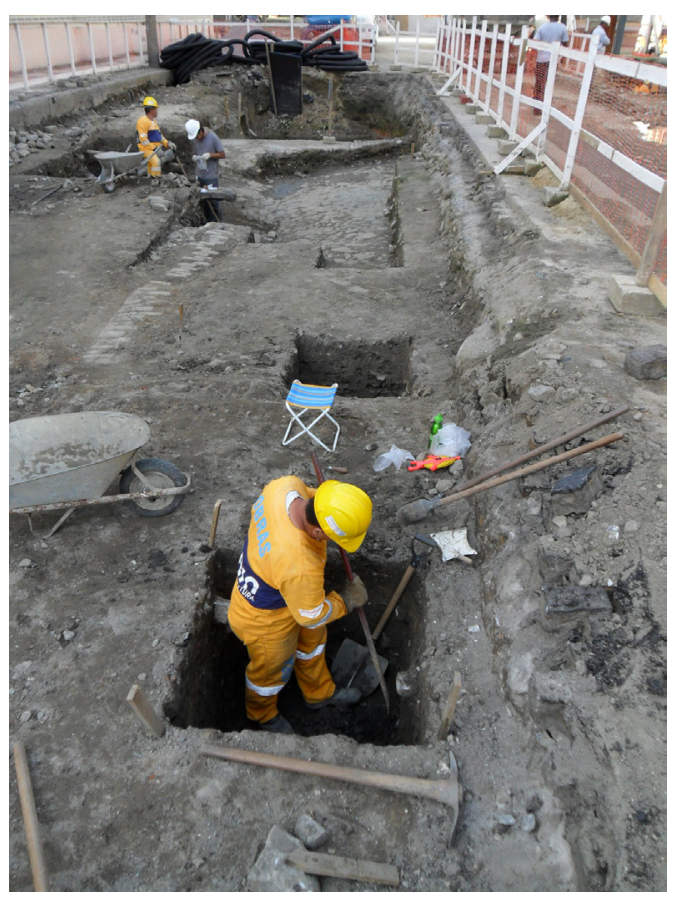

Figura 22 - Sucessão de sondagens ao longo da Frente 2, sempre com o calçamento do Cais do Valongo no fundo. 


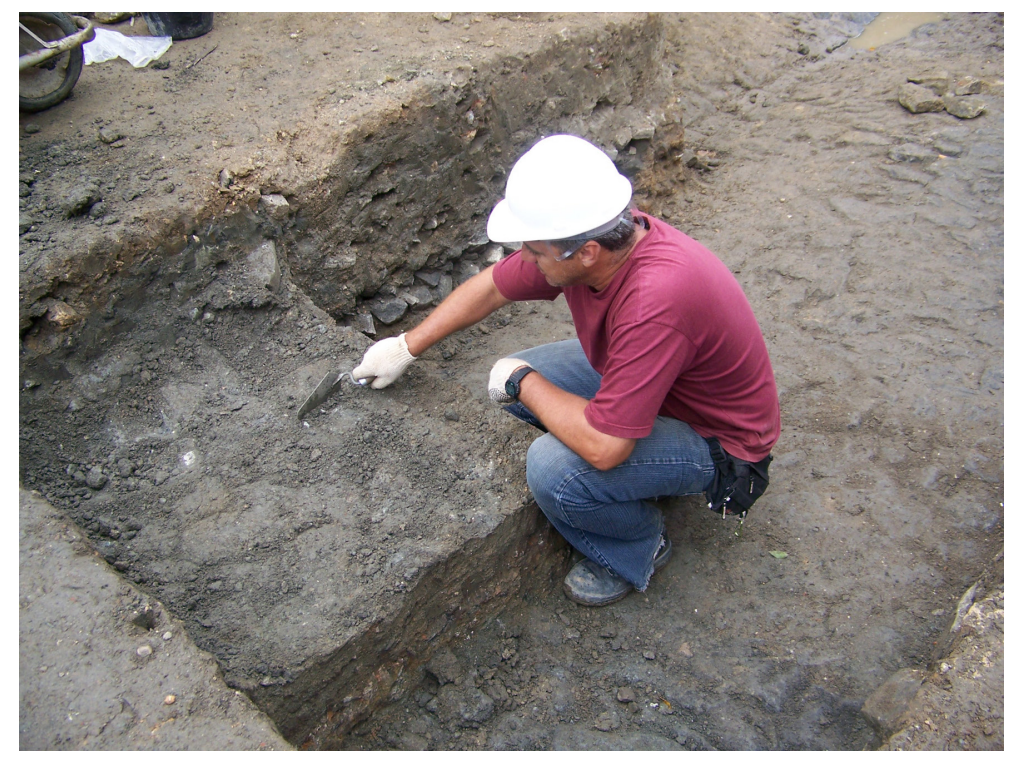

Figura 23 - Unificação das sondagens em trincheiras. Na base, o calçamento do Cais do Valongo.

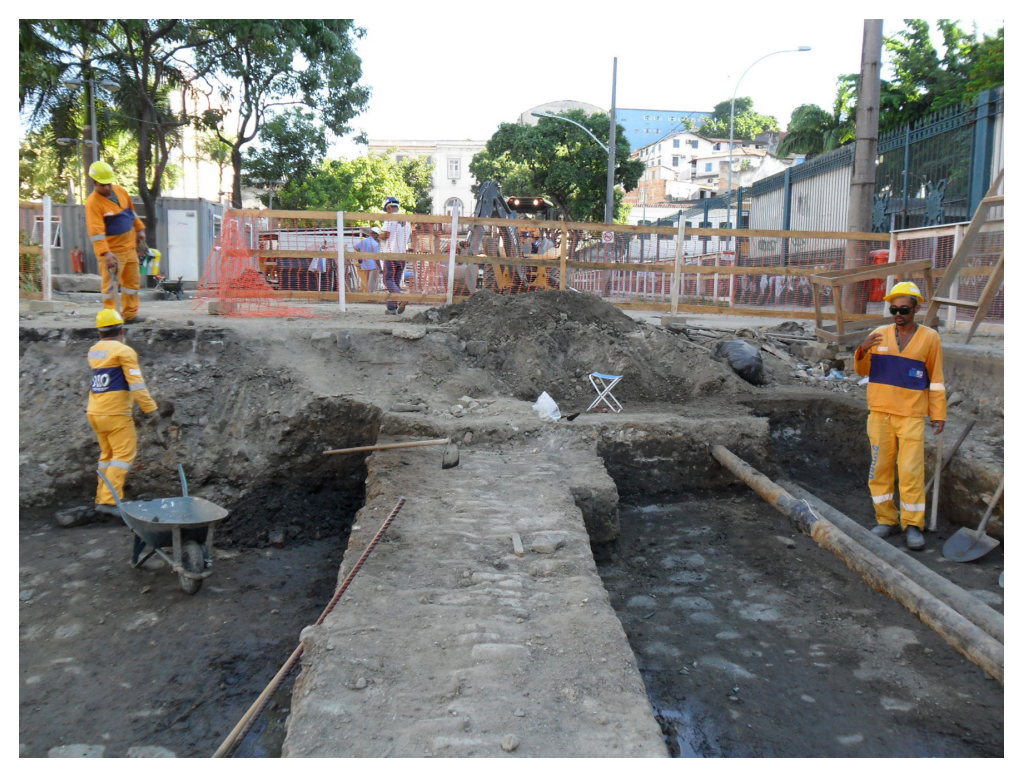

Figura 24 - Transformação das trincheiras em escavação em área ampla. Ao centro, segmento preservado do calçamento do Cais da Imperatriz.

As escavações realizadas na Frente 2 mostraram que, além do calçamento do Cais do Valongo se estender além dos limites da pista esquerda da avenida Barão de Tefé em direção ao terreno do vizinho Hospital dos Servidores do Estado, onde ele não podia mais ser acessado, foram observadas duas inclinações para drenagem de águas pluviais: um declive em direção ao mar, em seu eixo maior, e outro em direção à canaleta de escoamento que corta a Frente 2 (Figura 25). 


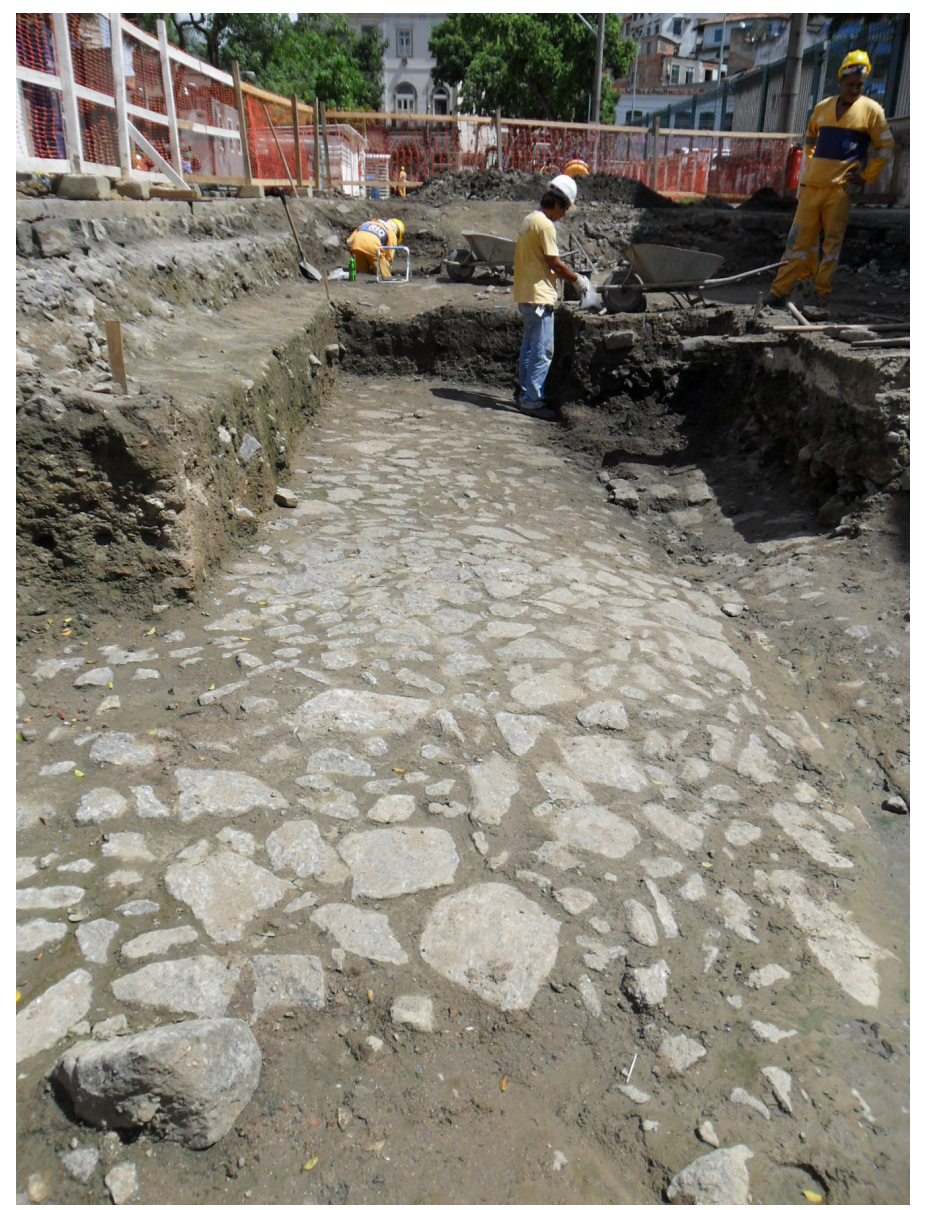

Figura 25 - Escavação em área ampla, expondo a inclinação do calçamento em direção à canaleta de escoamento de águas pluviais e em direção ao mar.

A Frente 3

Com o objetivo de unir os achados feitos nas duas extremidades, ou seja, nas pistas esquerda (Frente 1) e direita (Frente 2) da avenida Barão de Tefé (sentido rua Sacadura Cabral), foi aberta uma nova frente de escavação na Praça Jornal do Commercio, designada como Frente 3, entre as duas em andamento, medindo 5,40 m de comprimento e 3,20 m de largura, tendo sido alcançados, inicialmente, 1,40 $\mathrm{m}$ de profundidade (Figura 26). Foi observada a seguinte estratigrafia: até $0,10 \mathrm{~m}$, pedras portuguesas que recobrem atualmente a praça; entre 0,10 e 1,10 m, sedimento areno-argiloso, friável, de coloração acastanhada, correspondente a aterro; e entre 1, 10-1,40 m, sedimento argilo-arenoso de coloração acastanhada escura, também correspondente a aterro. Com o aprofundamento da escavação, atingiu-se entre 1,80 e 1,90 m de profundidade, tendo sido parcialmente expostas as lajotas de pedra atribuídas ao Cais da Imperatriz, compondo uma rampa. 


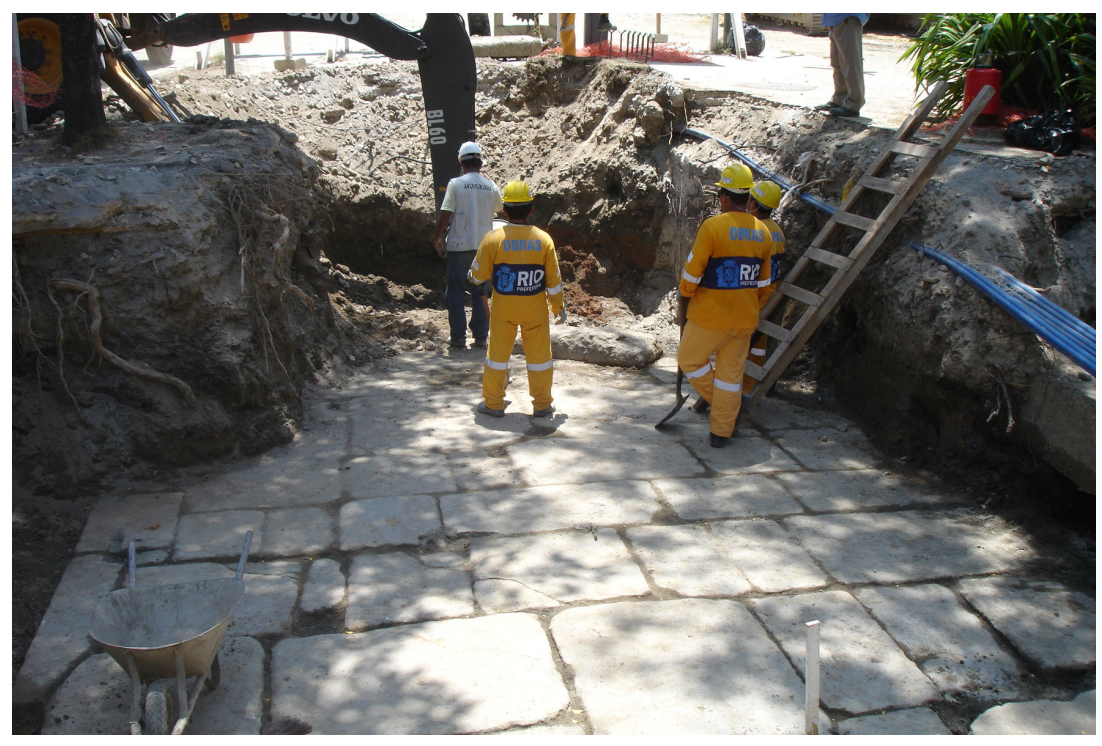

Figura 26 - Superfície das lajołas de pedra do Cais da Imperatriz, rampada em direção à Praça Jornal do Commercio.

No seu topo surgiu uma estrutura diferenciada, resultante do afastamento e do distanciamento dos dois degraus que apareceram na Frente 2 e que continuaram nessa Frente 3, mas com sua posição original alterada. Os blocos que a formavam, ao serem afastados, criaram um vazio que foi preenchido com pedras de mão, de modo a criar uma barreira defensiva contra o mar, no caso, um dissipador de energia hidráulica (Figura 27). Essa parece ter sido uma solução improvisada para atenuar a força e o impacto das ondas sobre o cais, constantemente danificado, como demonstram a estrutura remanescente e também o registro documental, que aponta sucessivos pedidos de reparos, ao longo do século XIX, para os danos provocados pelas "pancadas do mar". Descuidada em relação ao seu resultado pouco estético, essa intervenção parece ter sido bem tardia, feita decerto em um momento em que o cais já se encontrava consideravelmente degradado.

Com a escavação dessa estrutura para além de um envelopamento de energia elétrica e de um duto de fibra ótica que atravessavam a área, ela foi exposta em sua totalidade, permitindo constatar que foi grosseiramente sobreposta às lajotas de pedra do cais da Imperatriz (Figura 28).

A continuidade das escavações em direção ao mar expôs uma sequência de três degraus e mais um segmento de superfície rampada em lajotas de pedra, confirmando se tratar de uma área de desembarque (Figura 29).

Um importante achado foi feito nessa rampa: o deslocamento anterior, feito à época, de uma das lajotas de pedra que foi encontrada emborcada junto ao seu local original (ver figura 27), possibilitou a retirada do sedimento que preenchia o espaço abaixo dela. Foi escavada uma área de 2,10 $10,80 \mathrm{~m}$, em cujo nível inferior foi encontrado o calçamento de pedras irregulares do Cais do 
Valongo em forma de degraus (Figura 30), testemunhando que por baixo dessa frente avançada do Cais da Imperatriz ele está presente, e era da mesma forma escalonado, como consta no relatório do Intendente Paulo Viana, no qual ele afirma que fez "o Cais do Valongo no fim da rua deste nome com rampas e escadas para embarque". Também nesse acesso, as obras de construção do Cais da Imperatriz tão somente recobriram o velho Cais do Valongo, posto que não compensava, para a nova finalidade, o reaproveitamento das suas pedras irregulares.

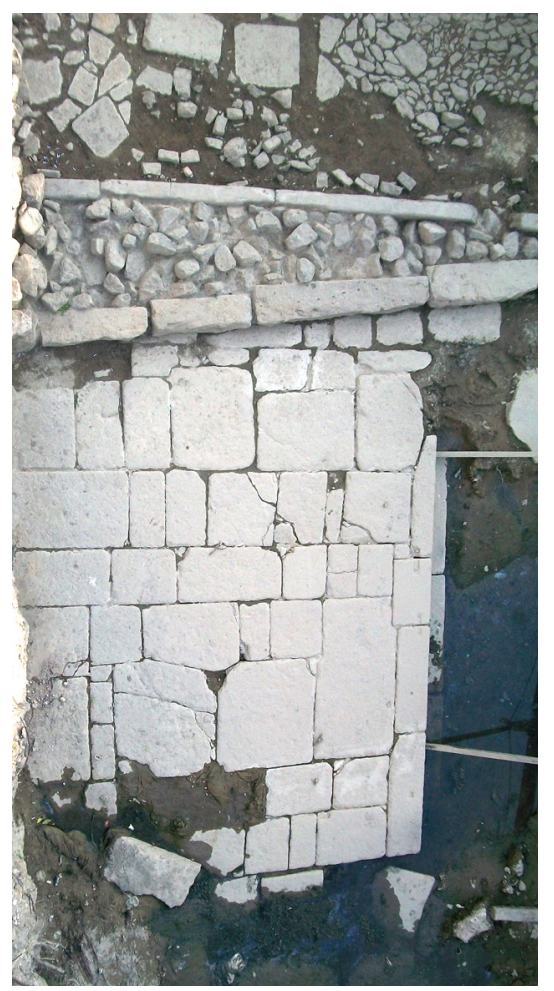

Figura 27 - Superfície rampada de lajotas de pedra e, ao alto, dissipador de energia hidráulica improvisado com o deslocamento dos blocos originais, criando um vazio que foi preenchido com pedras de mão.

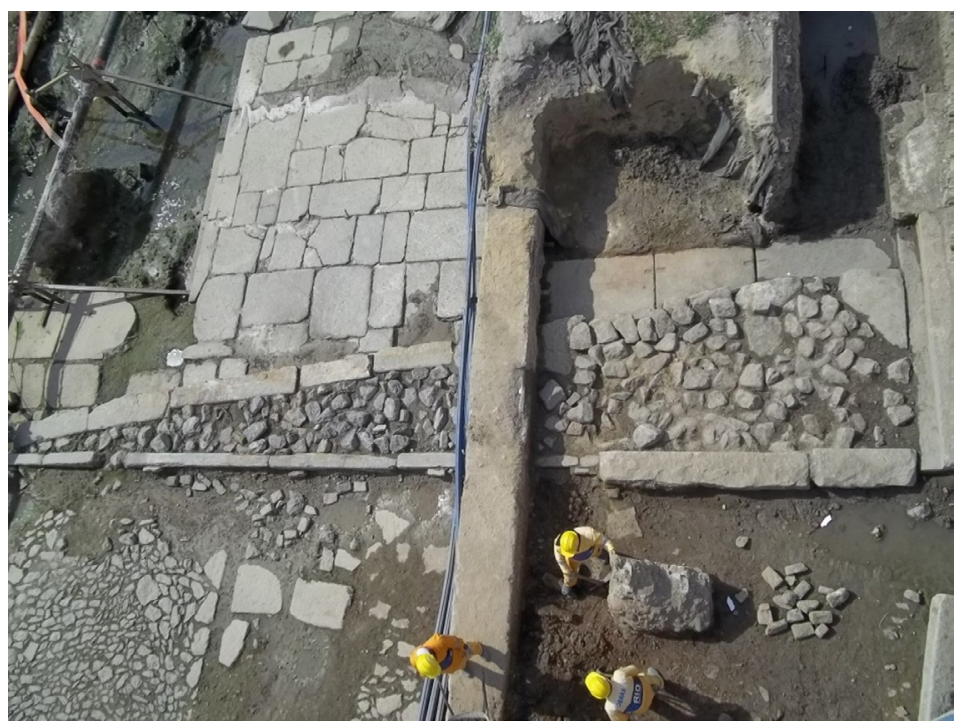

Figura 28 - Sobreposição grosseira de um dissipador de energia hidráulica sobre as lajotas do Cais da Imperatriz. 


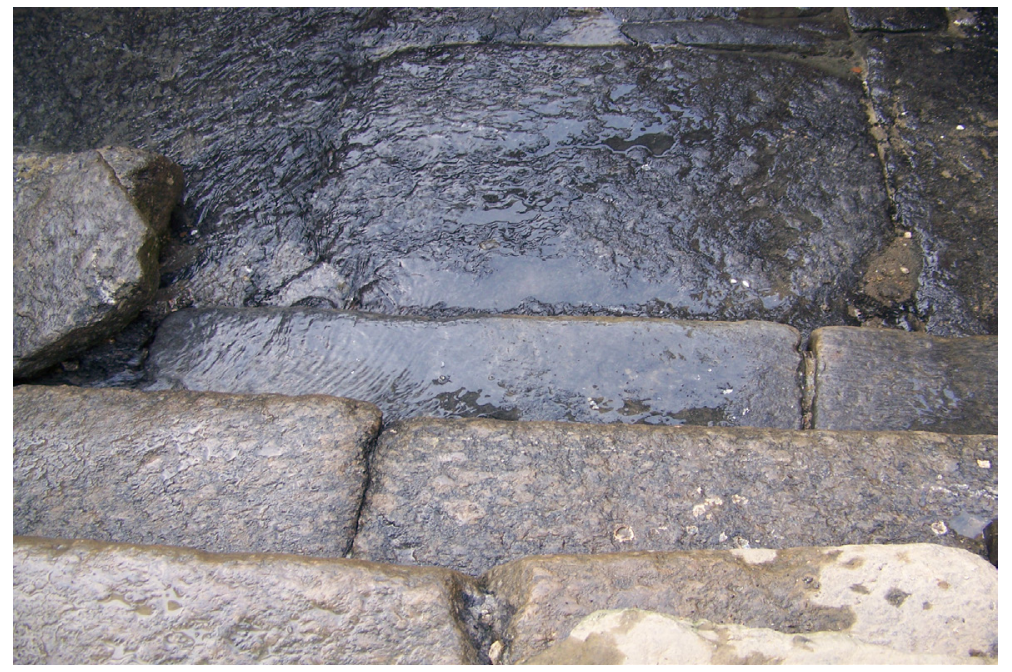

Figura 29 - Sequência de três degraus abaixo das lajołas de pedra do Cais da Imperatriz, em direção ao mar.

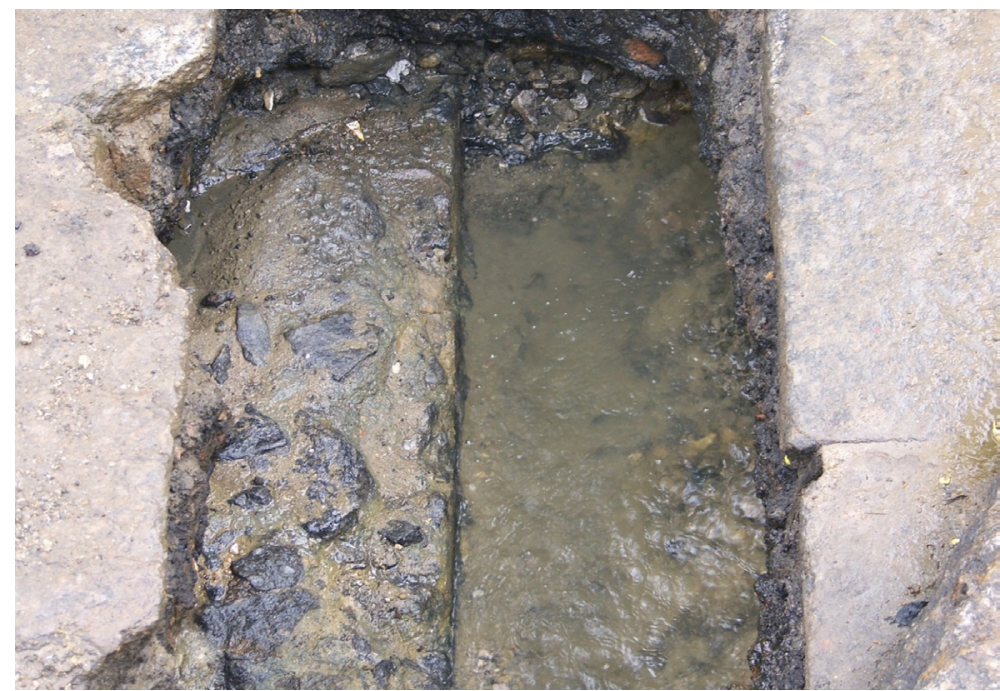

Figura 30 - Os degraus da escada do Valongo, em pedras irregulares, encontrada em escavação oportunística embaixo das lajotas de pedra do Cais da Imperatriz.

Várias lajotas do Cais da Imperatriz apresentaram evidências de terem sido amarradas umas às outras, para proteção contra as investidas do mar. Tal como exposto anteriormente, o registro documental faz referências à necessidade dessas amarrações das pedras, com grampos de ferro ou de bronze, de modo a impedir seu deslizamento (Figuras 31 a 33). Isso testemunha a força do impacto contínuo das ondas sobre o cais, também por inúmeras vezes mencionado nos documentos da época. Essa estratégia parece não ter sido suficiente, tornando necessário, em período mais tardio, o desmantelamento de um segmento dos degraus do Cais da Imperatriz e a improvisação, a partir deles, do já mencionado dissipador de energia hidráulica. 

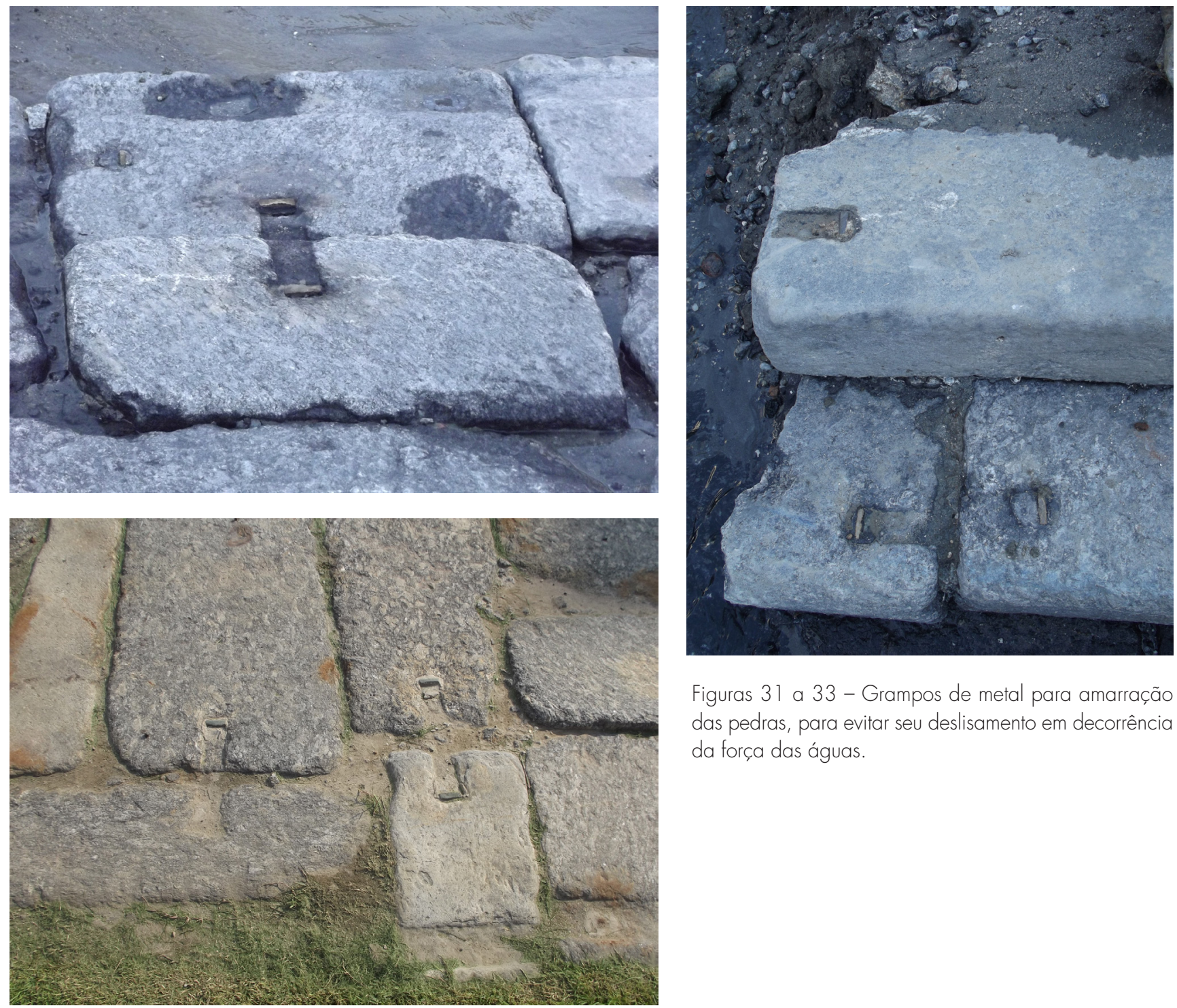

Figuras 31 a 33 - Grampos de metal para amarração das pedras, para evitar seu deslisamento em decorrência da força das águas.

Em outras lajotas, foram encontrados arganéis para cabos de amarração, fincados nas pedras, alguns deles ainda conservando restos das fibras vegetais utilizadas para essa finalidade, possivelmente de linho ou tucum (Figuras 34 a 39).

Paralelamente, as escavações tomaram o rumo oposto, em direção à coluna comemorativa da chegada da Imperatriz Teresa Cristina Maria. Em uma área de 10,0 × 8,0 m, surgiu o calçamento em pé de moleque do Cais do Valongo, a 1,70 m de profundidade (Figura 40).

No mesmo nível desse calçamento e portanto parte integrante do Valongo, foi identificado um segmento remanescente de lajotas de pedra de diferentes dimensões, tanto inteiras quanto fragmentadas, compondo um percurso alongado e relativamente estreito de 18,20 m de extensão, no primeiro trecho 

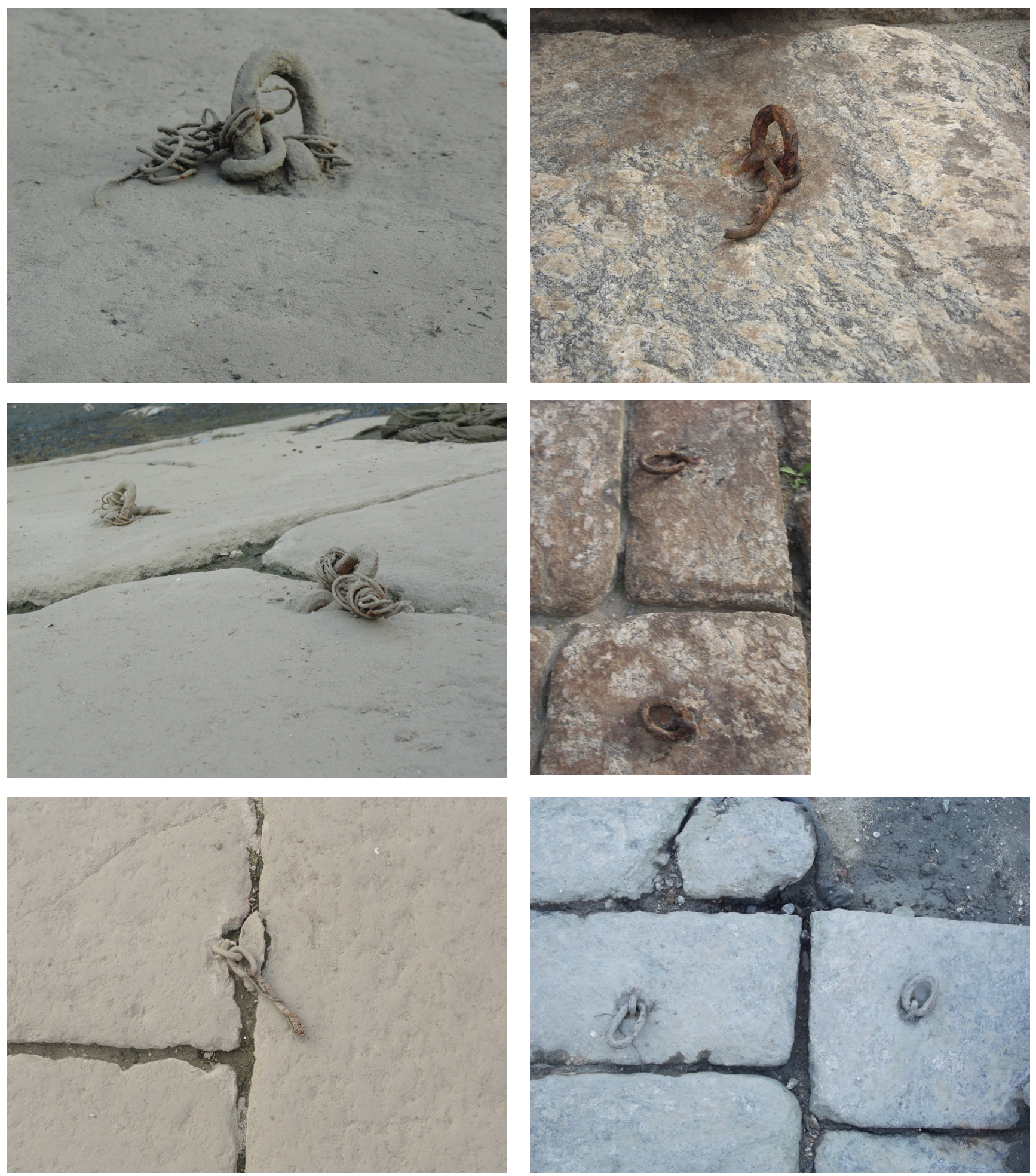

Figuras 34 a 39 - Arganéis para cabos de amarração encontrados fincados nas pedras do Cais da Imperatriz, alguns deles ainda conservando restos das fibras vegetais dos cabos. 


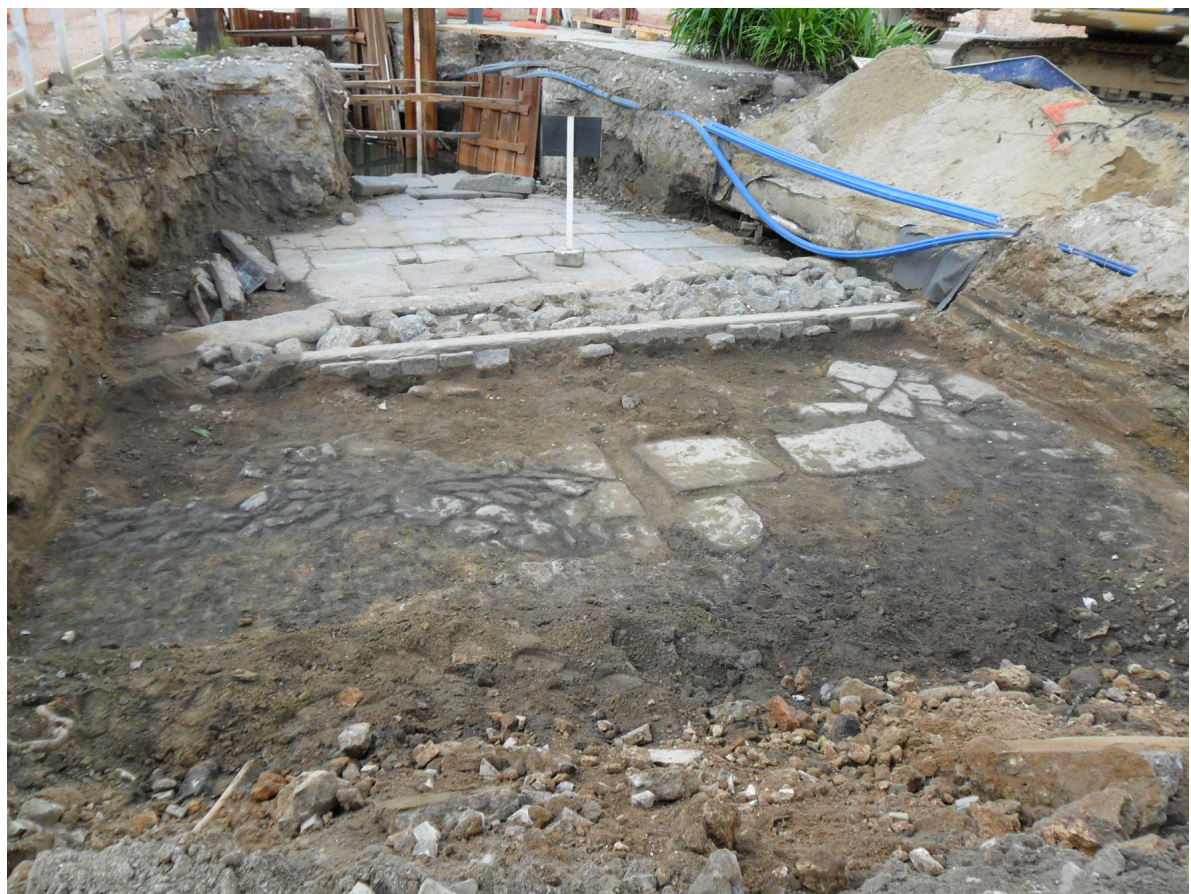

Figura 40 - Acima do dissipador de energia hidráulica, lajotas de pedra do Cais do Valongo e seu calçamento de pé de moleque.

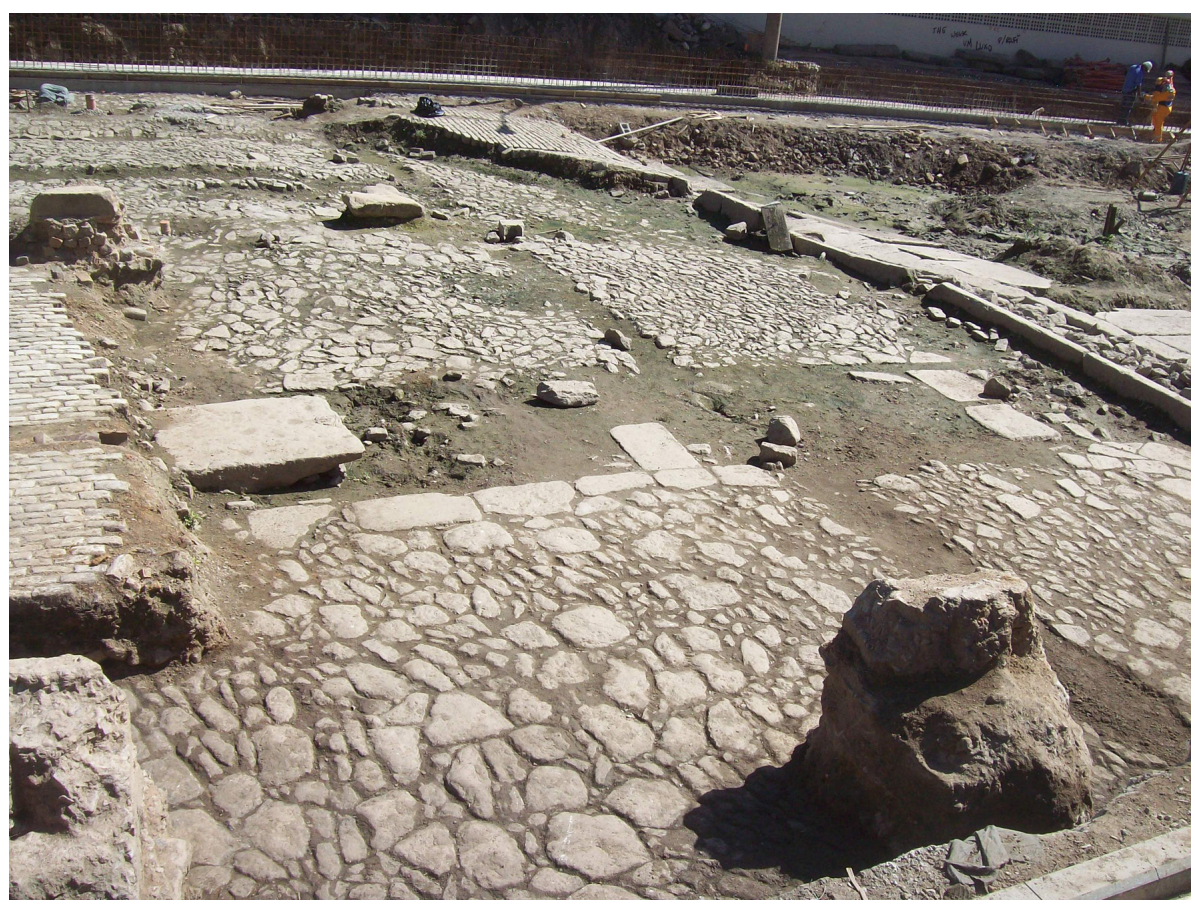

Figura 41 - Exposição ampla do calçamento do Cais do Valongo, correspondendo às Frentes 2 e 3. Ao fundo, uma das "ilhas" remanescentes do Cais da Imperatriz, com a superfície de paralelos cortada em diagonal, encontrada logo no início da escavação da Frente 2. 
visível, por 2,25 m de largura, centralizado como os degraus do cais e a coluna comemorativa. Restaram poucas lajotas do conjunto original, tendo desaparecido a maioria delas (Figura 4 1). Não foi possível avançar na exposição desse caminho por ter sido encontrado um trecho preservado do calçamento do Cais da Imperatriz, em uma área de aproximadamente 11,70 ×5,50 m, a 1,20 m de profundidade, mas que desapareceu próximo à coluna (Figura 42).

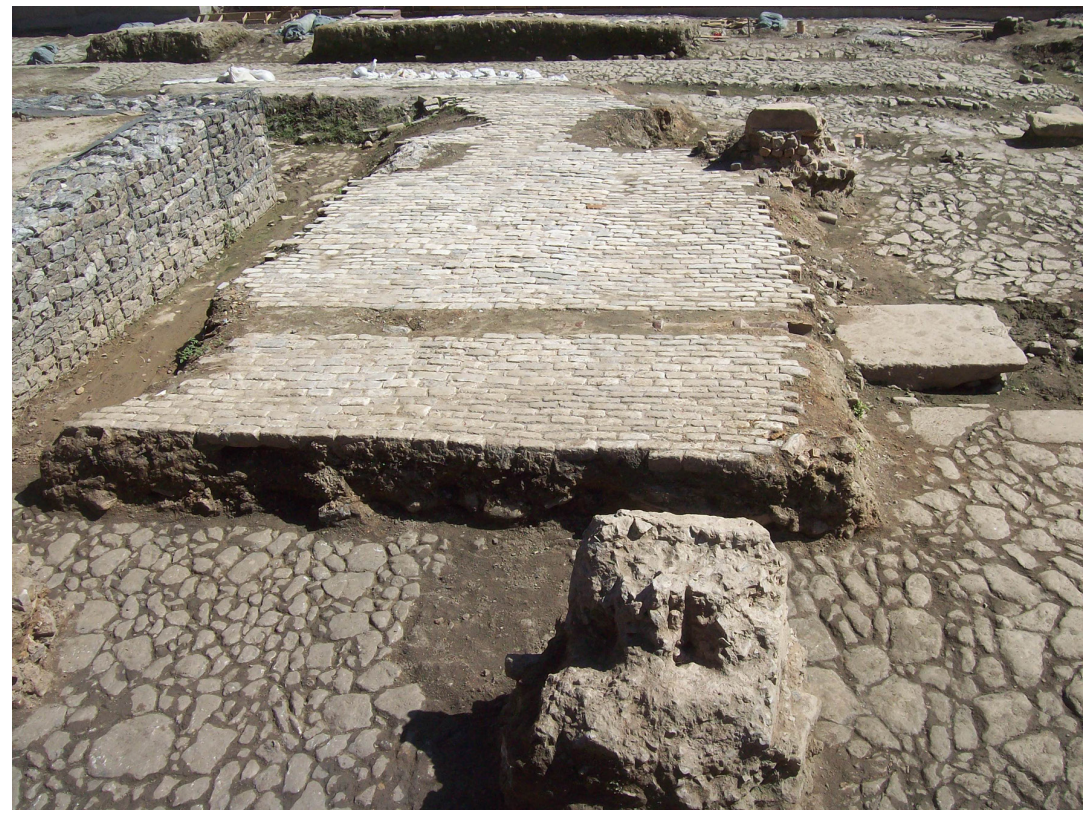

Figura 42 - $\bigcirc$ principal trecho remanescente dos paralelos do Cais da Imperatriz, compondo uma "ilha" em meio ao calçamento mais profundo do Cais do Valongo. $O$ muro de pedras que se vê à esquerda é recente, parte da estrutura de escoramento do marco comemorativo da chegada da Imperatriz Teresa Cristina Maria.

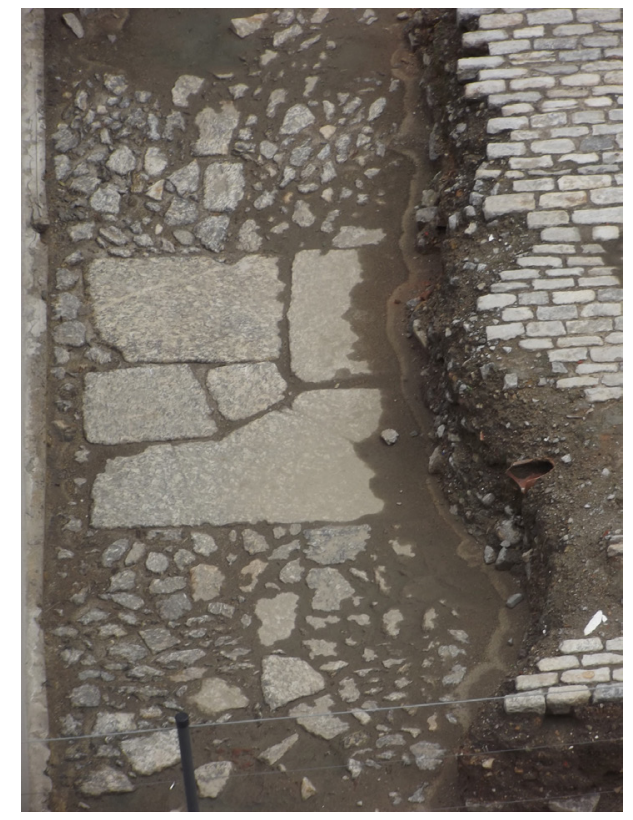

Figura 43 - Continuação do caminho de lajotas de pedra do Cais do Valongo, imediatamente em seguida à principal "ilha" de paralelos do Cais da Imperatriz, o único segmento intacto.

Contudo, logo após esse bloco remanescente do calçamento do Cais da Imperatriz reapareceu mais um segmento desse percurso, o único intacto e sem faltar pedra alguma. Trata-se de um retângulo de 2,20 x 1,80 m, formado por lajotas e fragmentos de lajotas de diferentes dimensões (Figura 43). Caso tenha existido esse percurso por baixo do trecho preservado do Cais da Imperatriz, o que é bastante provável, esse caminho tinha em torno de 26,0 m de extensão. Como, logo em seguida, foi colocada, na segunda metade do século XIX, a coluna comemorativa da chegada da Imperatriz do Brasil, não foi possível saber se esse percurso se prolongava ainda mais.

De cada lado da coluna comemorativa da chegada da imperatriz foram encontradas cinco bases para postes de iluminação (Figura 44). A presença de cimento na argamassa utilizada na sua construção permite atribuílas ao século XX. A julgar pela fotografia da Praça Municipal, de autoria de Augusto Malta (Figura 45), trata-se, provavelmente, de postes de iluminação posteriores aos do início do 
século, já que nela são visíveis apenas dois de cada lado. Em momento desconhecido, o sistema de iluminação da praça parece ter sido intensificado, ampliando-se para cinco as unidades que a ladeavam. Sua implantação, bastante profunda, chegou a danificar em alguns pontos o calçamento do Cais do Valongo.

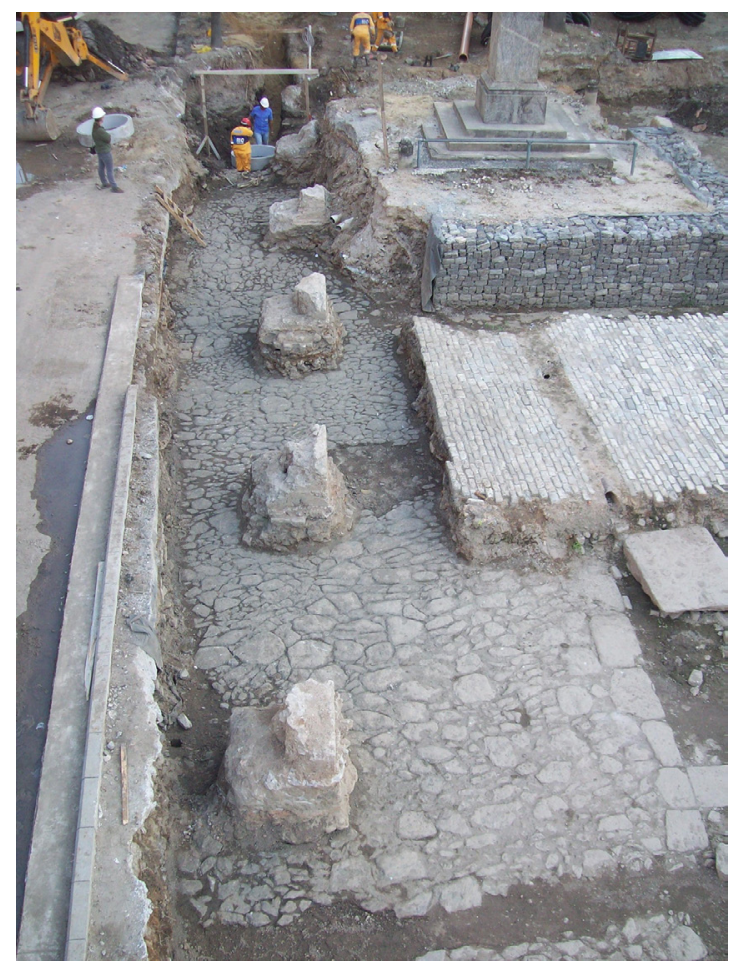

Figura 44 - Vista das bases dos postes de iluminação do século XX que ladeavam a coluna comemorativa do Cais da Imperatriz. Sua implantação chegou a danificar o calçamento do Cais do Valongo.

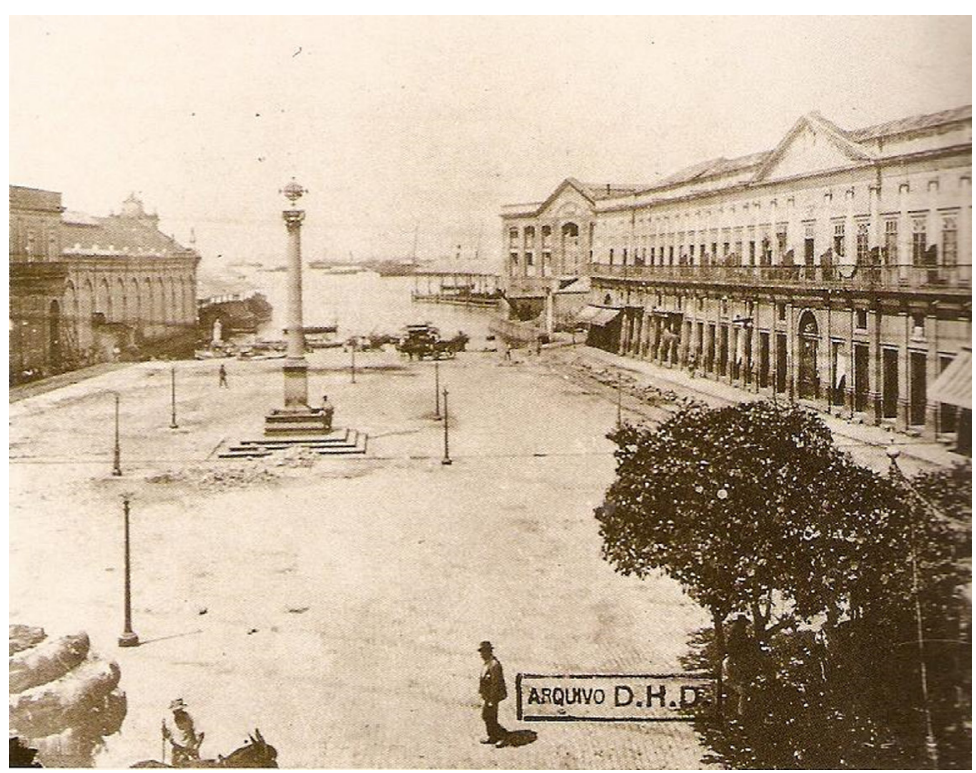

Figura 45 Praça Municipal, fotografia de Augusto Malta, início do século XX. À direita, ao fundo, o edifício das Docas D. Pedro II, e na lateral, o edifício que abriga atualmente o hotel Barão de Tefé. Fonte: Portal Augusto Malta, Arquivo Geral da Cidade do Rio de Janeiro (AGCRJ).

Ainda na Frente 3, foi escavada uma nova trincheira para a implantação da rede de esgoto, correndo paralelamente à longa trincheira da Frente 1 já descrita, porém no sentido contrário, da rua Sacadura Cabral para o cais. Por razões técnicas da obra, foi feito um desvio para dentro da área da praça, tendo essa nova trincheira alcançado $28,40 \mathrm{~m}$ de comprimento, 1,50 m de largura e 1,0 m de profundidade. No decorrer dessa escavação, foi encontrado um grande bloco retangular de granito finamente lavrado, em frente ao $\mathrm{n}^{\circ} 105$ da av. Barão de Tefé e junto ao meio-fio da Praça Jornal do Commercio, a 2,50 m de profundidade (Figura 46).

Sobre o bloco de granito lavrado, foram incrustadas as iniciais D DPII, em mármore preto e branco; e no alto, à esquerda, a data 15-09-1871 (Figura 47). No centro do bloco, um recorte quadrado na pedra, medindo $0,35 \times 0,35$ $\mathrm{m}$, sinalizava a existência de um compartimento interno, selado por uma tira de metal para impedir sua abertura (Figura 48). 


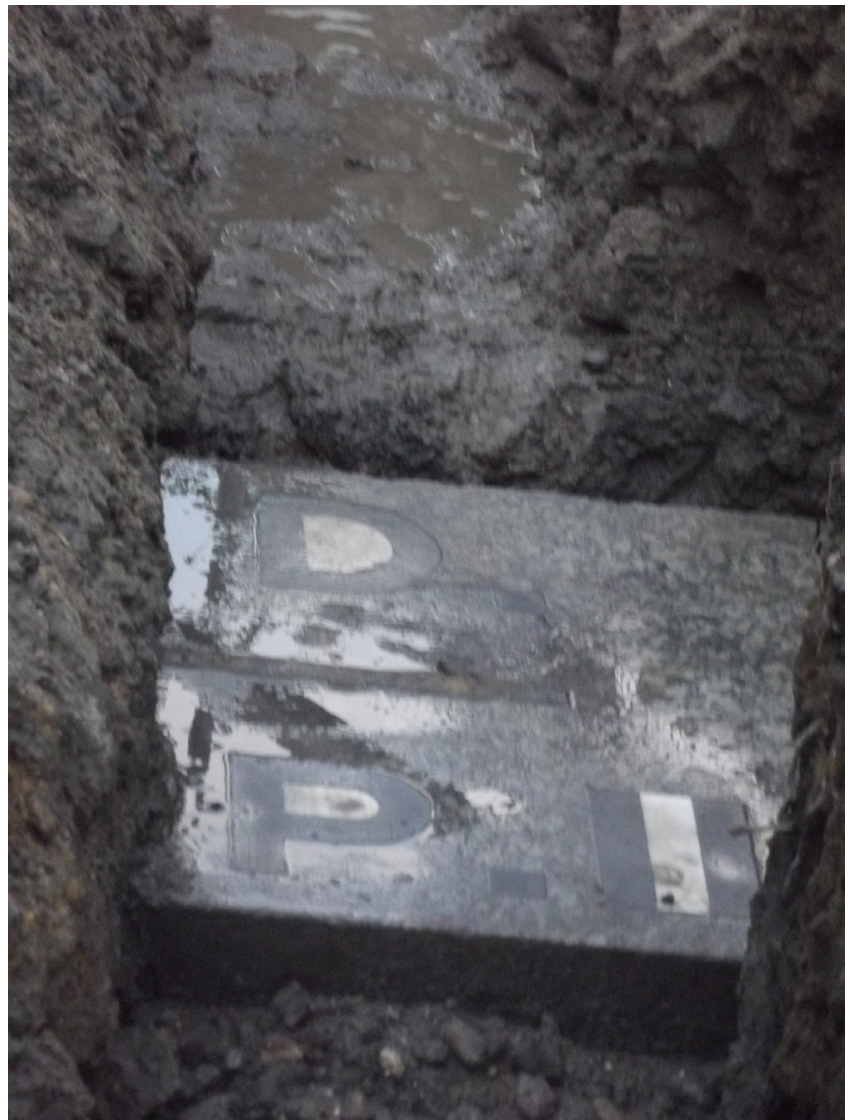

Figura 46 - $\bigcirc$ surgimento inesperado de bloco de granito lavrado em meio à escavação da trincheira para implantação da rede de esgoto.

Figura 48 - Tira de metal selando um recorte quadrado na pedra, sinalizando a existência de um compartimento interno no bloco de granito

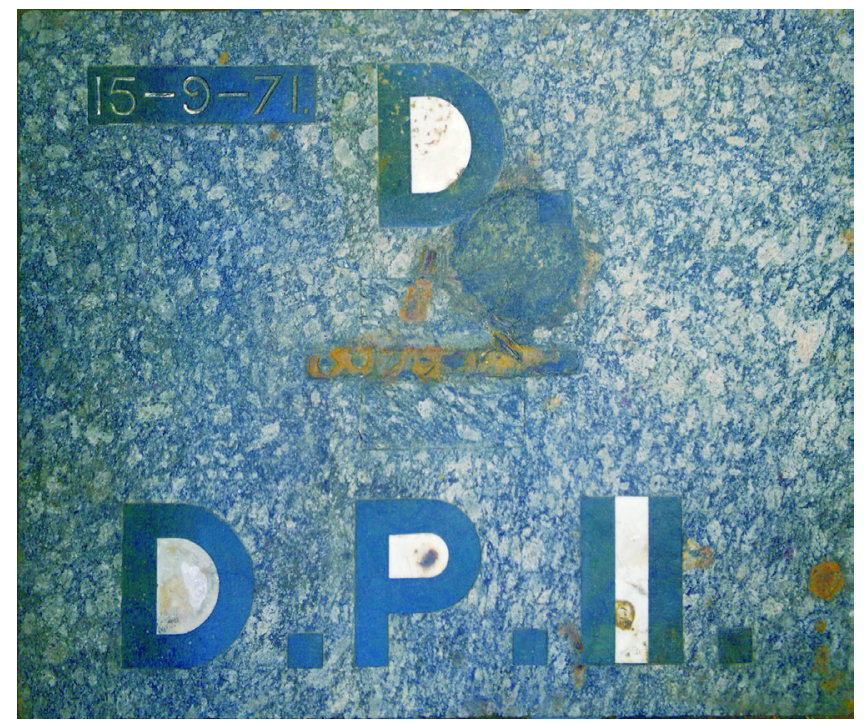

Figura 47 - Vista superior da pedra fundamental das Docas D. Pedro II

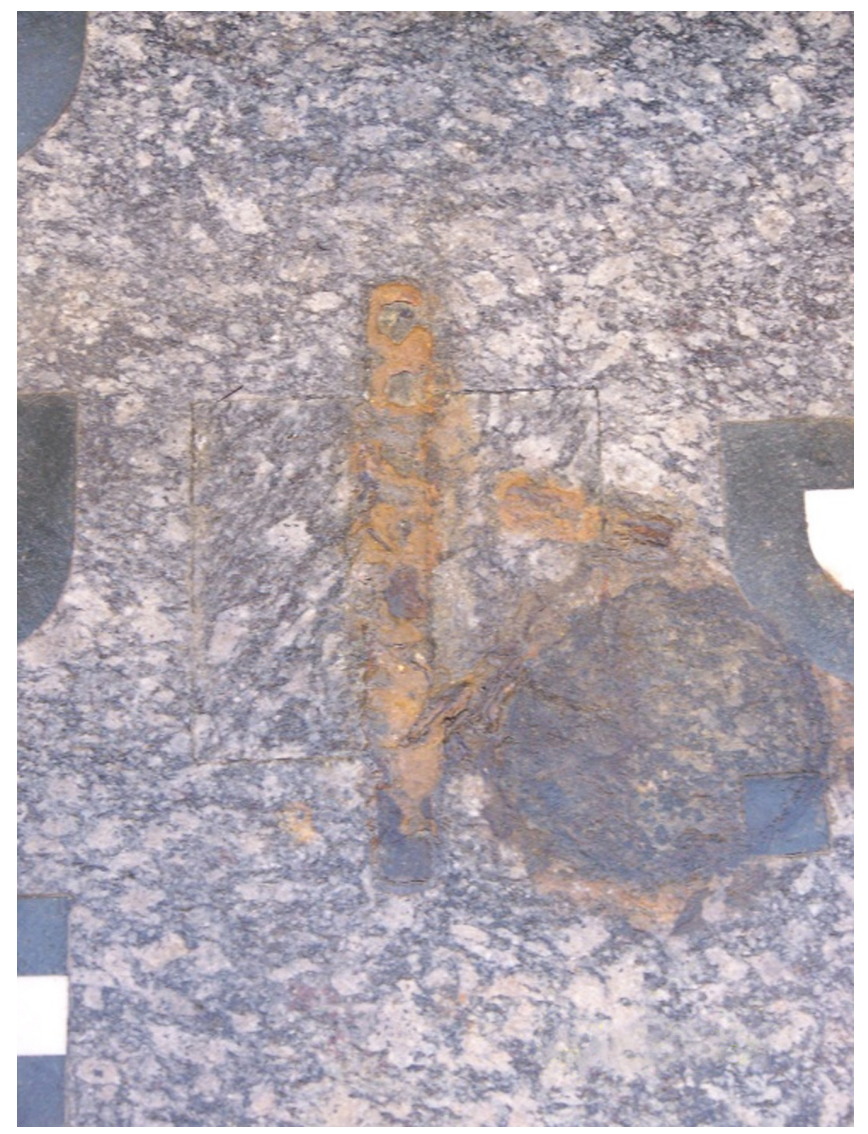


68. Ver Sergio Tadeu de Niemeyer Lamarão (2006). bloco foi progressivamente escavado à toda volta, de modo a ser exposto em sua totalidade, e também para verificar se a peça estava isolada ou associada a alguma estrutura. Após a sua exposição total, foi constatado que não havia outras evidências senão o bloco, cabendo então proceder a sua identificação. As iniciais, somadas à fina lavra, sugeriam tratar-se de peça de alguma forma associada ao imperador D. Pedro II, sendo a data um forte indicador de uma ocorrência relevante. Após rápida investigação, foi verificado que se tratava da pedra fundamental do edifício das Docas D. Pedro II, situado na quadra seguinte da Av. Barão de Tefé, próximo ao Cais da Imperatriz (Figura 49), a cerca de 60 m do local do achado. Essa grande distância é pouco usual, já que pedras fundamentais são em geral colocadas acima das fundações de uma construção, e não tão afastadas dela. Por ora é desconhecida a razão desse distanciamento, que pode ter sido decorrente de um açodamento em lançá-la, ainda que fora do lugar de praxe.

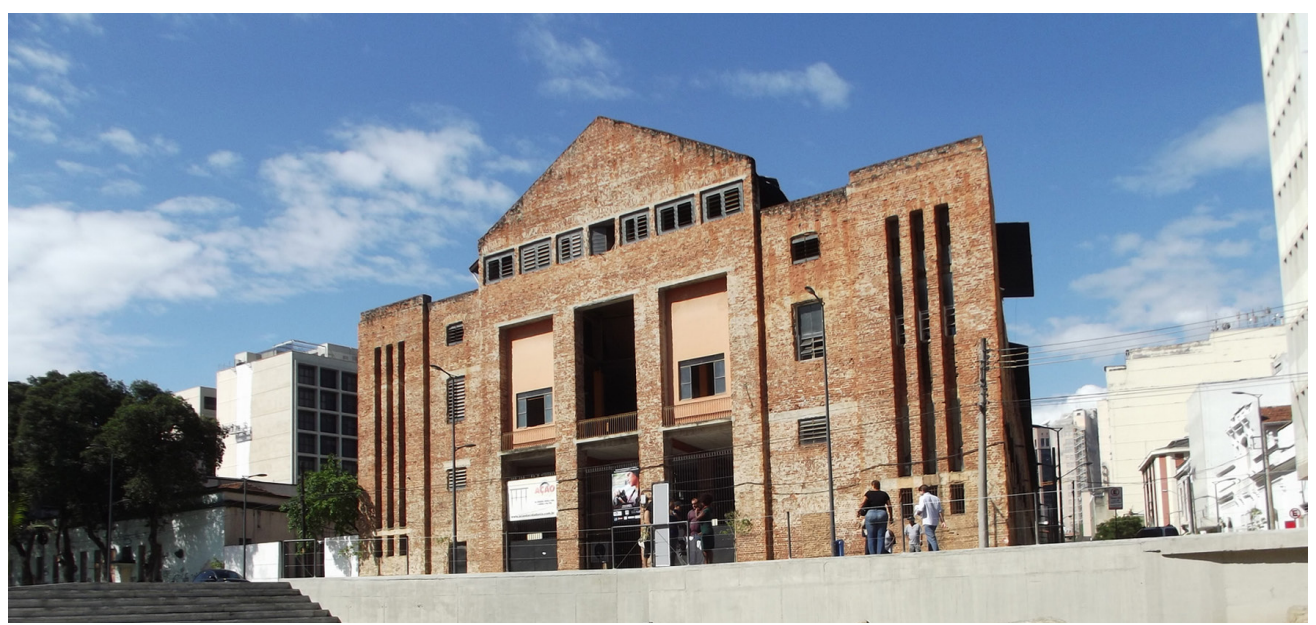

Figura 49 - O edifício das Docas D. Pedro II, ao lado do Cais da Imperatriz.

Restava, no caso, investigar o conteúdo do compartimento selado por uma tira de metal. É comum que pedras fundamentais tenham no seu interior o que se designa como cápsula do tempo, ou seja, algo que comprove, para a posteridade, a data em que ocorreu o evento que ela celebra, tratando-se, provavelmente, de um compartimento destinado a guardar esses testemunhos. Aberta posteriormente, em outubro de 2012, pelo Instituto Rio Patrimônio da Humanidade, de fato ela continha no seu interior uma caixa de madeira revestida de chumbo, contendo exemplares de jornais do dia do lançamento da pedra, a saber Diário Oficial do Império do Brasil, Jornal do Commercio e A Reforma, bem como nove moedas, de bronze, prata, cobre e ouro. Bastante danificados, os jornais foram recuperados e identificados por restauradores da Biblioteca Nacional.

edifício das Docas D. Pedro II foi idealizado como parte de um plano muito mais abrangente concebido pelo engenheiro André Rebouças, inspirado por uma visita sua às docas da Rainha Vitória, na Inglaterra ${ }^{68}$. Visando a modernização 
das atividades portuárias, que padeciam então de considerável ineficiência e morosidade crônica, seu plano consistia em um grande empreendimento que envolvia a construção de uma estação marítima acoplada à ferrovia D. Pedro II, e de ramais que seriam conectados à estrada de ferro. Dessa forma seria possível diminuir os custos operacionais e facilitar o embarque e o desembarque de mercadorias, especialmente do café. Seriam construídos grandes armazéns próximos ao cais, que agilizariam a movimentação dessas mercadorias, estando previstos ainda estaleiros para construção naval e diques para a manutenção de embarcações. Em seu projeto de junção do terminal ferroviário com o litoral, Rebouças concebeu uma rede de docas que seriam implantadas à beira mar na Saúde e na Gamboa, cobrindo o litoral norte da cidade, desde a Prainha até a Gamboa. O ramal ferroviário passaria pela rua Larga de São Joaquim (atual av. Marechal Floriano), junto ao Colégio Dom Pedro II, desviaria para a rua da Imperatriz (atual rua Camerino), até chegar à Saúde.

A primeira delas a ser implantada foi a Docas D. Pedro II, e, para viabilizála, Rebouças associou-se à Stephen Busk \& Co, da empresa de navegação Liverpool Brazil and Riner Plate Mail Steamers, em 1868, sob os auspícios do imperador, que cedeu seu nome ao empreendimento. A pedra fundamental da nova companhia foi assentada no dia 15 de setembro de 1871, ao meio-dia, em requintada cerimônia de inauguração das obras de sua construção. Ausente o imperador, então no exterior, foi realizada em presença de Sua Alteza Imperial, a Princesa Regente Dona Isabel Cristina de Bragança e Bourbon e de seu marido, o Príncipe Consorte Dom Luís Filipe Gastão de Orléans, Conde d'Eu, além de outros membros da nobreza. Os príncipes se dirigiram ao local na galeota imperial, com numerosos convidados que foram transportados em barcas das Companhias Fluminense, Ferry e Mauá, profusamente adornadas para a ocasião. Desembarcando na ponte flutuante do Largo da Imperatriz (antigo Cais do Valongo), foram recebidos em pavilhão armado no centro da praça, especial e ricamente decorado para a ocasião.

Contudo, a solenidade transcorreu sob forte tensão. O Diário do Rio de Janeiro publicou matérias, em 15 de setembro de 1871 e também no dia seguinte 69 , sobre a vigorosa reação dos proprietários das marinhas das enseadas da Saúde e da Gamboa, encaminhada em documento à princesa regente D. Isabel. Nesse protesto, eles reclamavam que o privilégio fora concedido a alguns poucos, sem a concorrência de outros que exerciam a mesma função, configurando um monopólio. Da mesma forma, os moradores acusavam a empresa de prepotência, ao se apossar de terrenos públicos e de interferir nas obras realizadas na Praça Municipal, inclusive desmanchando o calçamento já pronto, para o assentamento da pedra fundamental.

A Câmara Municipal embargara a obra na véspera da solenidade, o que foi descumprido por ordem de André Rebouças. Oficiais de justiça voltaram à Praça Municipal no dia da cerimônia, durante os preparativos para o assentamento da pedra, e ratificaram o embargo, "nada mais podendo fazer em respeito às pessoas presentes". A companhia foi multada por "embaraçar logradouro público" sem ter requerido a 
necessária licença. Mesmo assim a cerimônia prosseguiu, tendo sido oferecido aos convidados, na volta, um banquete com "três mesas de 50 talheres cada uma".

$\bigcirc$ prédio das Docas D. Pedro II foi concluído em 1875, alterando substancialmente seu entorno, em especial os trapiches da antiga rua da Saúde (atual rua Sacadura Cabral) que perderam o acesso ao mar e, por conseguinte, sua função, tendo sido inúteis os veementes protestos de seus proprietários.

A demora em conseguir viabilizar o restante do projeto acabou por deitar por terra os planos de Rebouças, com a agravante de que a então rua da Imperatriz era estreita e curvilínea, totalmente inadequada para a implantação de uma linha de trem. De tal forma que do grandioso plano de Rebouças restou apenas o prédio das Docas D. Pedro II.

A Frente 4

Tendo sido constatados, na Frente 2, remanescentes do Cais do Valongo e do Cais da Imperatriz, era preciso investigar a extensão de ambos em direção à rua Sacadura Cabral. Para tanto, uma nova frente de escavação foi aberta, designada como Frente 4, ao longo da via à direita da av. Barão de Tefé, em continuação à Frente 2. Visando o controle sobre os achados, a Frente 4 foi dividida em trechos equivalentes aos da galeria de águas pluviais da av. Barão de Tefé, por se tratar de duas vias paralelas, separadas apenas pela Praça Municipal. A Frente 4 começou no Trecho 7 e se estendeu até o 14, próximo à esquina com a rua Sacadura Cabral.

Após o corte e a retirada do asfalto, foi feita uma sequência de dez sondagens de 1,0 x 1,0 m, 2,0 × 1,0 m e 2,0 × 2,0 m em intervalos de 5,0 m (de S 1 a S 10). De modo geral, com pequenas nuances, a estratigrafia da Frente 4 se mostrou semelhante à da Frente 2, tendo o calçamento do Cais do Valongo aparecido nas cinco sondagens iniciais, em profundidades variadas, de acordo com o aclive da área em direção à rua Sacadura Cabral, entre 1,50 m e 1,05 m, estando a última a apenas 9,0 m de distância dela. Nas demais sondagens, apareceu piso de terra batida bastante compactado, entre 1,45 m e 1,18 m de profundidade, acompanhando o aclive mencionado acima (Figura 50).

Após a realização das sondagens e seus resultados, a opção metodológica foi a escavação de superfície ampla, promovendo-se a ligação entre os cortes exploratórios tal como foi feito na Frente 2, de modo a expor os remanescentes tanto do Cais da Imperatriz quanto do Cais do Valongo, onde eles foram detectados. $\bigcirc$ registro das novas áreas escavadas foi feito tomando-se como base as sondagens que haviam sido previamente realizadas nessa frente.

Inicialmente, foi escavado o trecho entre S3 e S4, entre a superfície e $1,20 \mathrm{~m}$. A estratigrafia mostrou-se semelhante à encontrada em S3 e S4. À profundidade de 1,20 m, apareceram o calçamento do Cais do Valongo e a canaleta de escoamento de águas pluviais, continuidade da mesma estrutura encontrada na Frente 2. 


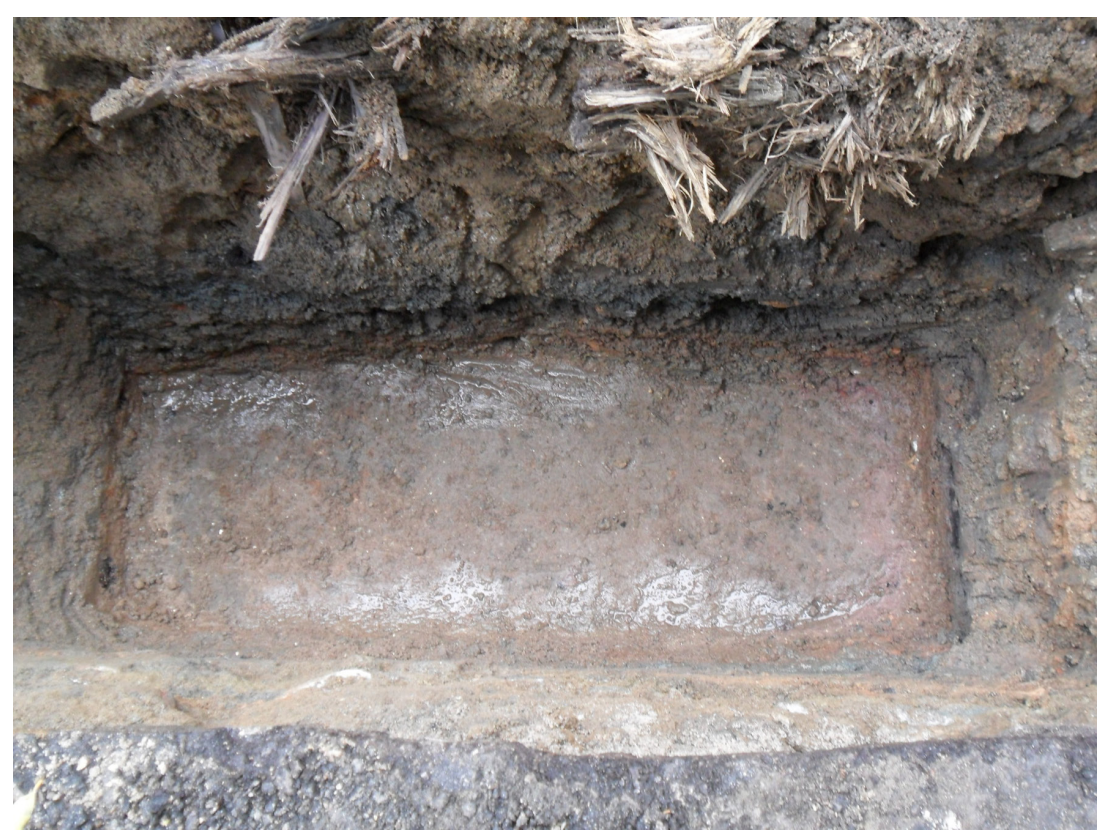

Figura 50 - Piso de terra batida muito compacto no fundo das sondagens posteriores da Frente 4.

No trecho entre Sl e S6, a estratigrafia mostrou-se semelhante à encontrada em S3 e S4. O Cais do Valongo surgiu preservado em S1, a uma profundidade de 1,46 m. Em S3, a 1,35 m, e em S5, a 1,20 m, acompanhando o aclive em direção à rua Sacadura Cabral, foi exposto mais um segmento da canaleta.

Totalmente preservado entre S1 e S2, a partir daí e em direção à rua Sacadura Cabral, o calçamento do Valongo apresentou falhas ou deslocamentos de pedras em função de perturbações anteriores. Em S4, elas se tornaram mais evidentes, existindo trechos nos quais ele está totalmente ausente. Em S6, o calçamento desapareceu de todo, não ocorrendo mais daí em diante. Entre S7 e S10 foi encontrado apenas um piso de terra batida muito compacto.

Escavado o trecho entre S6 e S7, a estratigrafia mostrou-se semelhante à que foi verificada em S3 e S4. Em dois pequenos trechos com as medidas de 1, 10 $\times 1,0 \mathrm{~m}$ e 1,10 $\times 0,85 \mathrm{~m}$, foram encontrados segmentos preservados do calçamento do Cais da Imperatriz, indicando que havia uma continuidade do trecho encontrado entre S2 e S3. Não foram identificados vestígios do calçamento do Cais do Valongo. No limite entre S5 e S6, foi encontrada uma tubulação de gás que cruzava toda a área de escavação, no sentido sul-norte, à profundidade de 1,20m.

Foi feita a escavação manual em uma área de 1,0 x 1,0m, denominada atipicamente como SV 1 por se tratar de sondagem abaixo do nível do Valongo, em um trecho onde o calçamento estava ausente. A escavação foi iniciada à profundidade de 1,25 m (tomada a partir da cobertura de asfalto), no mesmo nível do Cais do Valongo nesse trecho. A estratigrafia encontrada foi a seguinte: camada 
1, 1,25-1,40 m, arenosa, acinzentada escura; camada 2, 1,40-1,42 m, arenoargilosa, amarelada, muito compacta, provável contrapiso do calçamento do Cais do Valongo; camada 3, 1,42-1,65 m, areno-argilosa, escura, com maior densidade de materiais construtivos; camada 4, 1,65-1,80 m, argilo-arenosa, acinzentada, totalmente estéril.

Em seguida, foi escavado o segmento entre S7 e S8, que apresentou a mesma estratigrafia das demais sondagens feitas nesse trecho. Não foram encontrados vestígios do calçamento do Cais do Valongo, tendo aparecido apenas dois pequenos segmentos preservados do Cais da Imperatriz, no mesmo alinhamento do que foi verificado entre S2 e S3. Esses segmentos se situavam próximo a S7.

Durante essa escavação foram encontrados três esteios de madeira alinhados, e um fora da sua posição original, a saber: E1, na altura do Trecho 10 da Frente 1, foi encontrado fincado in situ, parcialmente decomposto, medindo $0,20 \times 0,12 \mathrm{~m}$ e a 1,05 $\mathrm{m}$ de profundidade; E2, na altura do Trecho 11 da Frente 1, medindo $0,20 \times 0,17 \mathrm{~m}$ e a 1,00 $\mathrm{m}$ de profundidade, fincado in situ; E3, também na altura do Trecho 11, medindo 0,18 $\times 0,17 \mathrm{~m}$, e a 0,90 m de profundidade, também fincado in situ; E4 estava a aproximadamente $3,0 \mathrm{~m}$ do esteio 3, a 0,50 m de profundidade, porém em posição horizontal (Figura 51 ).

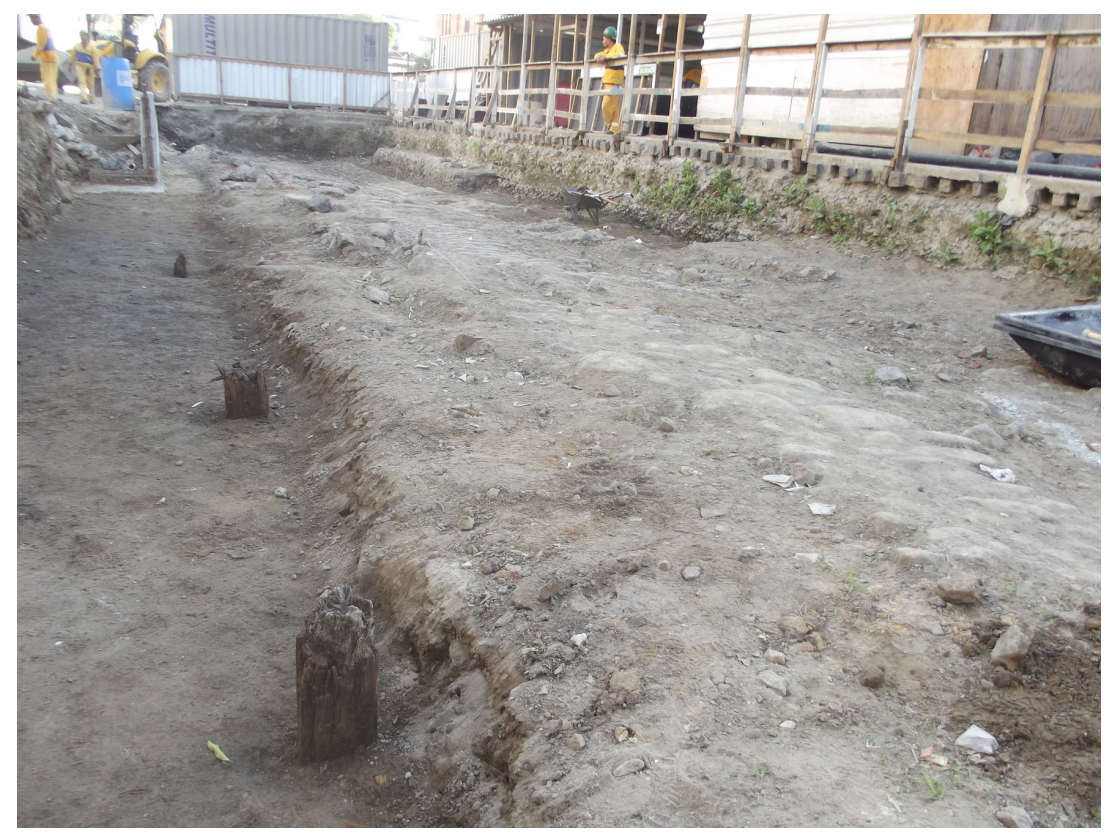

Figura 51 - Sequência de esteios surgidos durante a escavação da Frente 4.

A unificação desses cortes expôs um amplo segmento do Cais do Valongo, danificado em alguns pontos em razão da passagem de redes subterrâneas, primorosamente construído, com uma canaleta para o escoamento de águas pluviais e cuidadosos arremates delimitando-o, assim como duas "ilhas" remanescentes do Cais da Imperatriz (Figuras 52 a 55). 


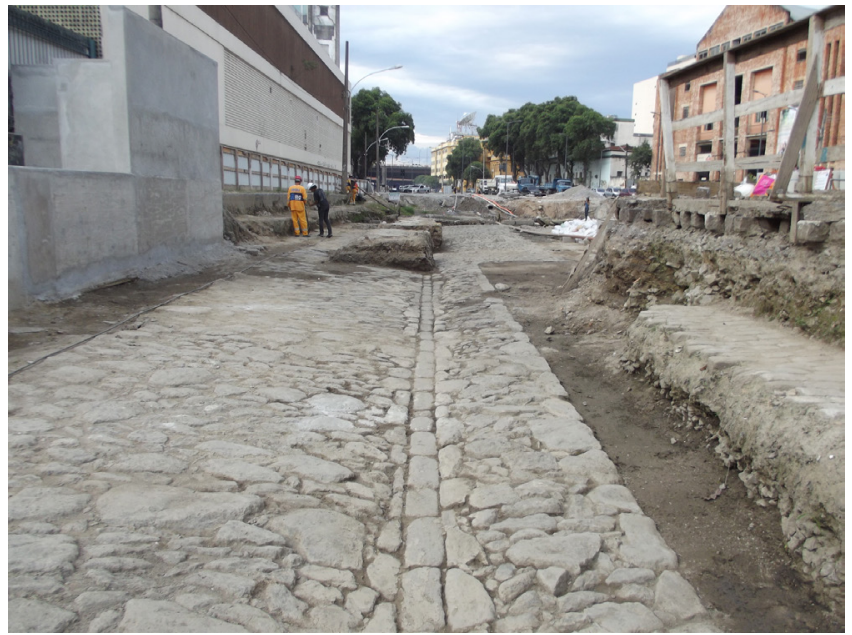

Figura 52 - A exposição do calçamento do Cais do Valongo na Frente 4, direção sul, e a canaleta de escoamento de águas pluviais. À direita vê-se a o cuidadoso arremate do calçamento no limite com o piso de terra. À esquerda, o edifício do Hospital dos Servidores do Estado. À direita, o edifício das Docas D. Pedro II.

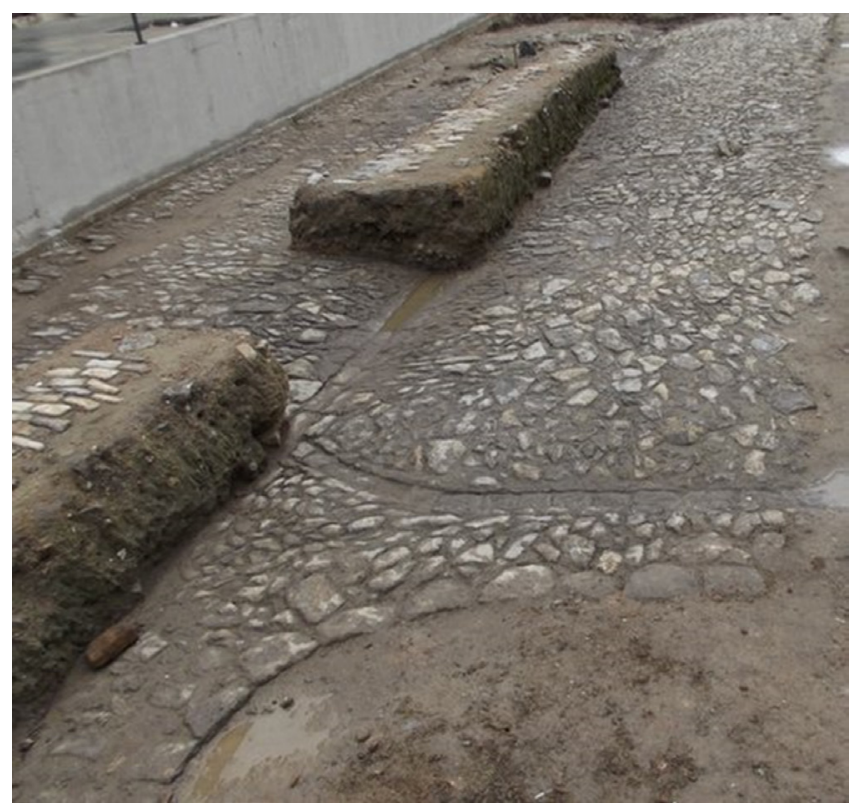

Figura 54 - A sudeste, o calçamento terminou no ponto onde aparece o do Cais da Imperatriz, em um nível mais elevado, tendo sido suas pedras, cuidadosamente, alinhadas de modo a formar uma borda que o arremata. Essa borda faz uma curva que delimita a área atualmente ocupada pela praça, em cujo interior não foram encontrados vestígios do calçamento do Valongo. Paralelamente a ela, corre uma canaleta secundária, a qual desemboca naquela que atravessa as Frentes 2 e 4 , atestando o primoroso sistema de drenagem de águas pluviais implantado no Cais do Valongo.

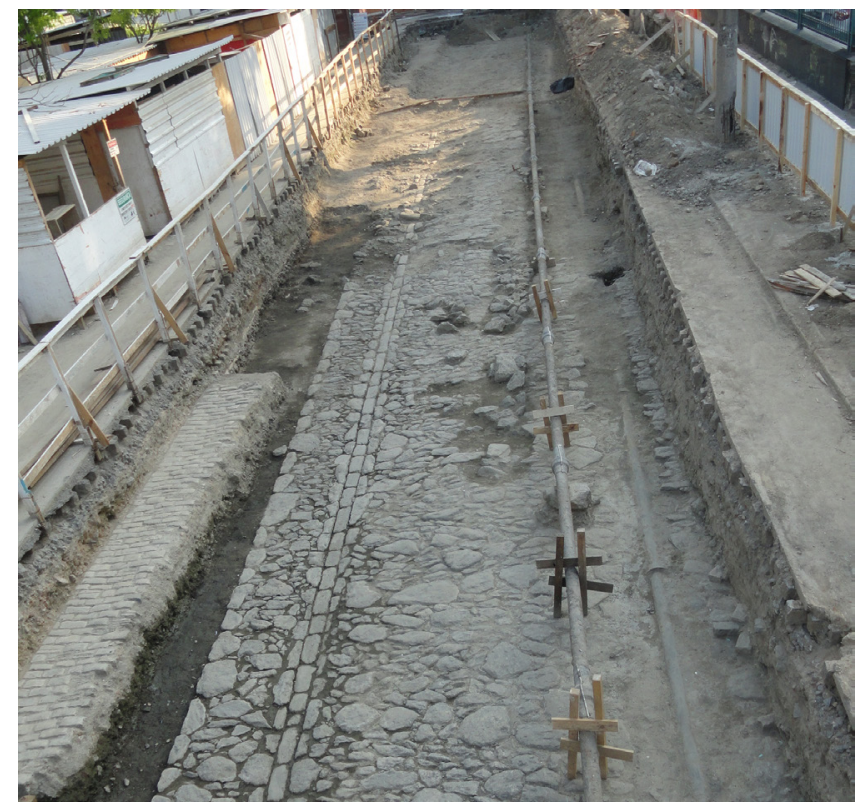

Figura 53 - A Frente 4 totalmente escavada, vista da direção sulnorte, com exposição do calçamento do Cais do Valongo, e sua primorosa canaleta de escoamento de águas pluviais. A tubulação que atravessou essa área danificou-o sobretudo no seu trecho posterior. À esquerda vê-se, em nível superior, um segmento remanescente do piso de paralelos do Cais da Imperatriz.

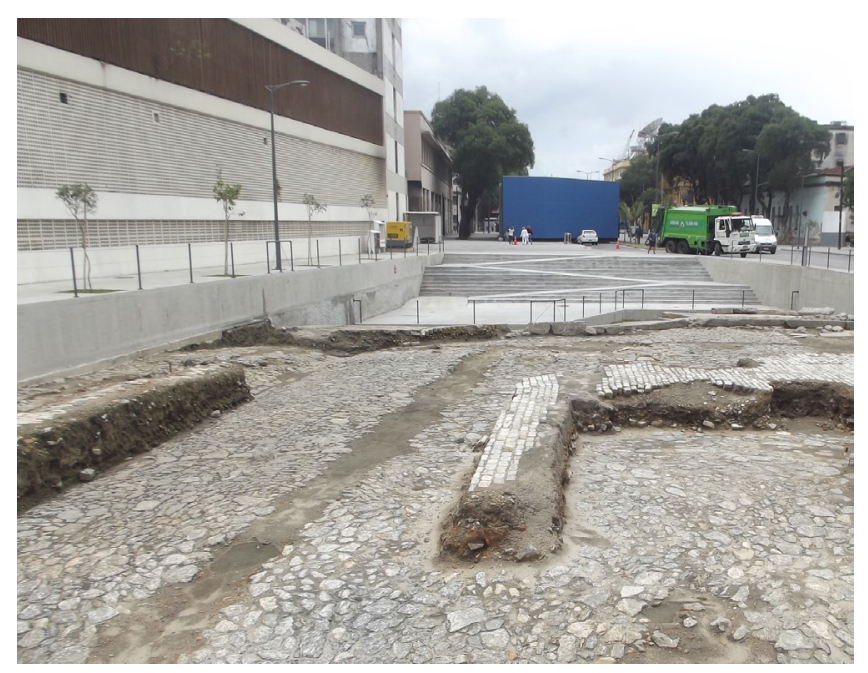

Figura 55 - Em nível mais elevado, as "ilhas" remanescentes do Cais da Imperatriz, muito danificadas pela implantação de diversas redes subterrâneas. Ao centro, vê-se uma das várias cicatrizes deixadas no calçamento do Cais do Valongo pela passagem de uma tubulação mais profunda. 
Nessa Frente 4, no limite com a Praça Jornal do Commercio, foi visualizado um perfil bastante ilustrativo, que mostra os quatro momentos da sua trajetória, desde o início do século XIX até hoje (Figuras 56 a 59):

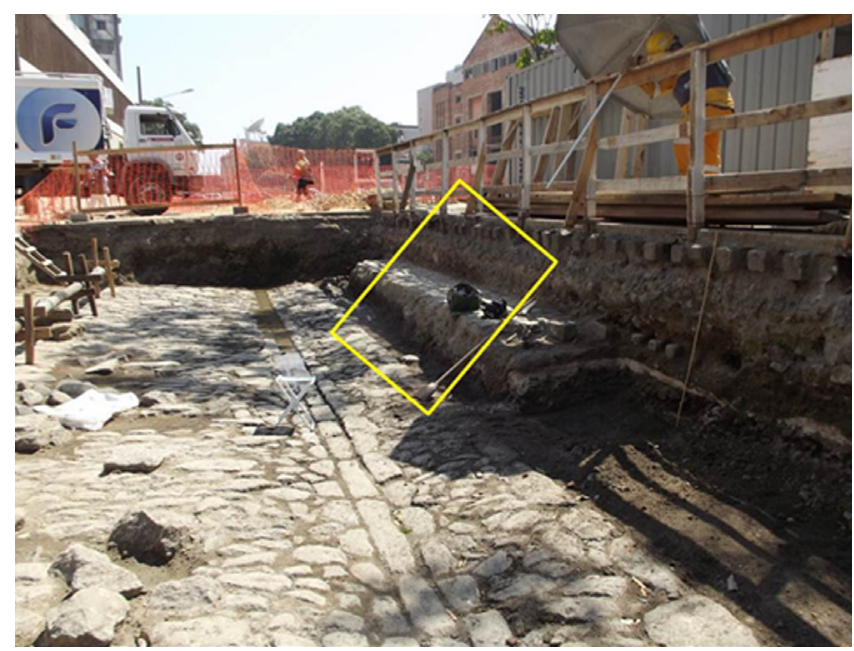

Figura 56 - Localização do perfil exposto na Frente 4.
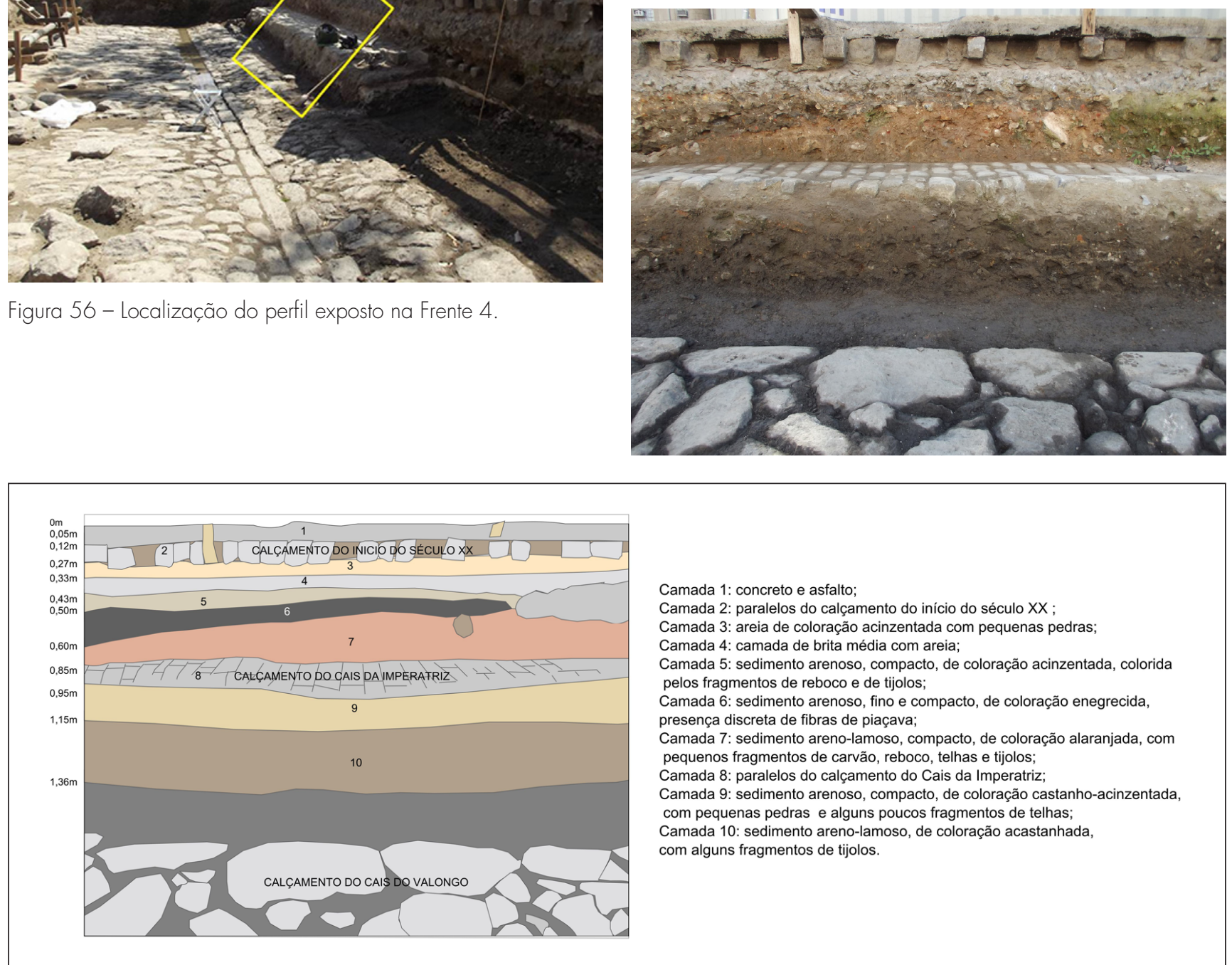

Figuras 57 e 58 - Perfil apresentando claramente as diferentes e sucessivas ocupações da praça hoje designada como Praça Jornal do Commercio: em primeiro plano e no nível inferior, vê-se o calçamento do Cais do Valongo, seguido do aterro feito para a construção do Cais da Imperatriz. Seguem-se os paralelos do seu calçamento e o novo aterro feito no início do século XX, quando foi encoberto o Cais da Imperatriz e colocados novos paralelos na Praça Municipal. Por fim, sobre esses últimos, a fina camada de concreto que os recobriu para a execução do piso mais recente de pedras portuguesas, substituído agora por placas de granito, no trabalho de reurbanização da Praça Jornal do Commercio, em decorrência da exposição do Cais do Valongo. Desenho do perfil: Andrea Jundi Morgado. Vetorização: Lucas Araújo Costa. 


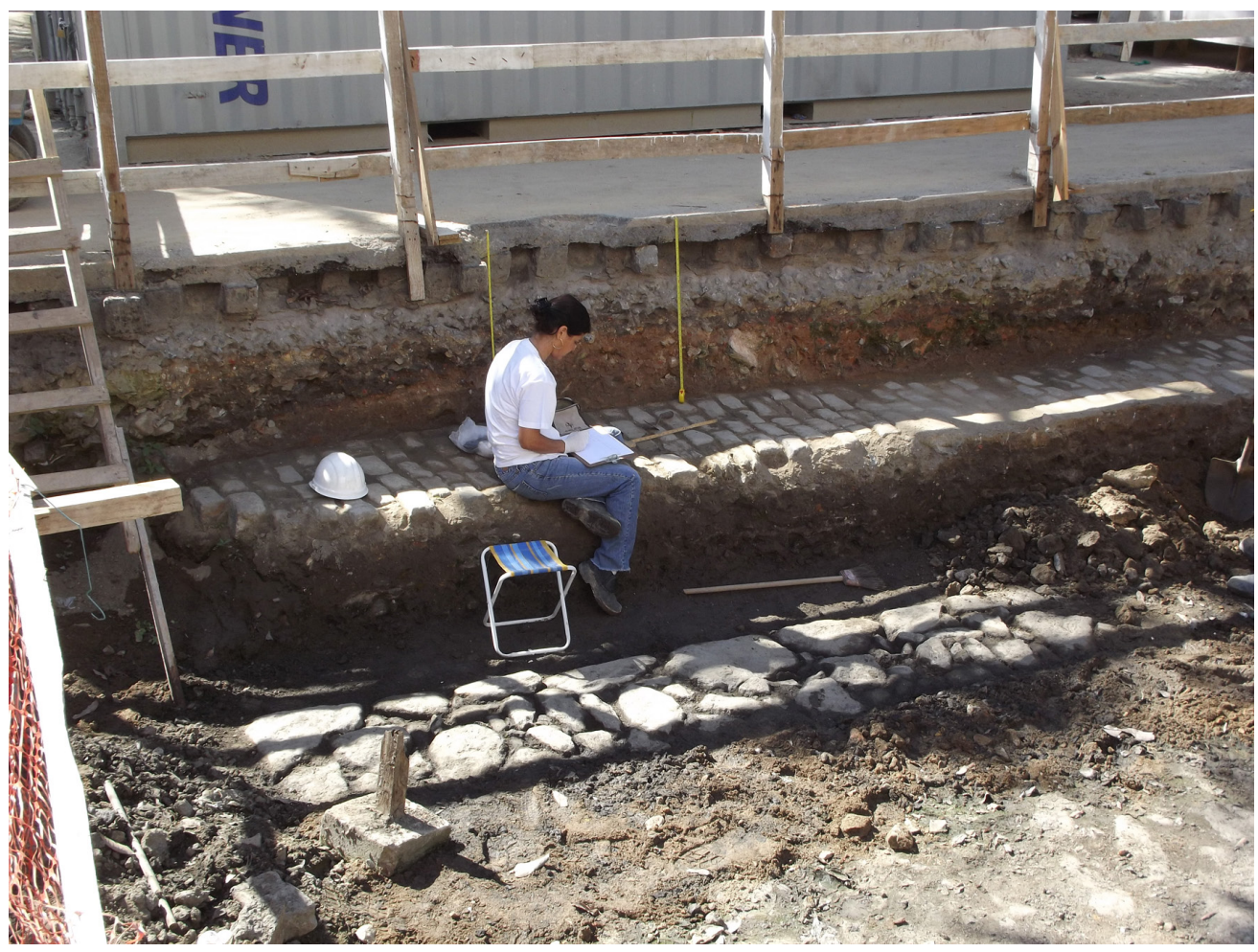

Figura 59 - A sucessão estratigráfica que expõe os diferentes momentos da trajetória da atual Praça Jornal do Commercio.

A Frente 5

Escavadas as duas pistas de rolamento da avenida Barão de Tefé e a parte dianteira da Praça Jornal do Commercio, foi preciso verificar se o calçamento do Cais do Valongo se estendia até a praça propriamente dita, embora as bordas bem arrematadas sugerissem que ali estava o seu limite. Com o objetivo de delimitálo, foram feitas nove sondagens, de 2,0 × 1,0 m, onde nada foi encontrado referente aos calçamentos do Cais da Imperatriz e do Cais do Valongo. Em cinco delas, entretanto, foi encontrado um piso de terra batida entre 1,20 e 1,30 m de profundidade 70 .

Mais três sondagens, com a mesma medida, foram feitas em intervalos regulares de 4,0 m. Em uma delas foi encontrada uma lajota de pedra a 0,72 m de profundidade; paralela a ela, e a 0,40 m abaixo, uma outra lajota. Para se avaliar do que se tratava, foram abertos novos cortes ao norte e ao sul, agora medindo 3,0 × 1,0 m, adaptando-se a medida da unidade de escavação às características do achado. Foi mantida a designação desses cortes como sondagens, pois não era possível prever àquela altura o rumo e a natureza da intervenção a ser adotada, que dependeria do que viesse a ser encontrado. Tendo em vista que outras lajotas foram expostas em sequência, o conjunto foi sendo
70. Para o detalhamento das sondagens feitas em todas as frentes e descrição de sua estratigrafia e conteúdo, ver Relatório "Cais do Valongo/ Cais da Imperatriz". Caderno com 111 pranchas, janeiro de 2013, depositado na Superintendência do Iphan no Rio de Janeiro. 
gradativamente escavado acompanhando a orientação das pedras, na tentativa de delimitá-lo. Com esse procedimento, o que era originalmente sondagem acabou por se configurar como quadriculamento de área.

A sequência de lajotas foi pouco a pouco compondo uma moldura de uma área central preenchida com sedimento, permitindo supor que se tratava da base do chafariz mais antigo, implantado na Praça Municipal entre 1842 e 1843, cuja existência era conhecida por meio do registro documental. Foi exposta uma estrutura quadrangular escalonada, feita de pedras lavradas de granito, estreitas e alongadas, com diferentes dimensões, unidas com argamassa de cal e argila. No patamar inferior que a circunda, de 0,60 m de largura, a estrutura mede 7,0 $\mathrm{m} \times$ 7,15 m. Um bordo elevado de 0,15 m corria originalmente a sua volta, aumentando sua largura para $0,75 \mathrm{~m}$. Sua função era evitar o transbordamento das águas, que eram escoadas por quatro ralos de cerca de 0,35 $\mathrm{m} \times 0,25 \mathrm{~m}$, posicionados, aproximadamente, no meio de cada um dos seus lados.

Já a moldura superior do chafariz apresentou $0,60 \mathrm{~m}$ de largura, medindo $6,0 \mathrm{~m} \times 5,70 \mathrm{~m}$. As lajotas que formam seus quatro ângulos são maiores, de formato aproximadamente quadrado ou retangular, tendo sido uma de suas extremidades abatida de modo a conformar cantoneiras, que foram reforçadas internamente por pedras soltas, de dimensões pequenas e médias. Foram encontrados dois dutos de cobre que o abasteciam de água (Figura 60).

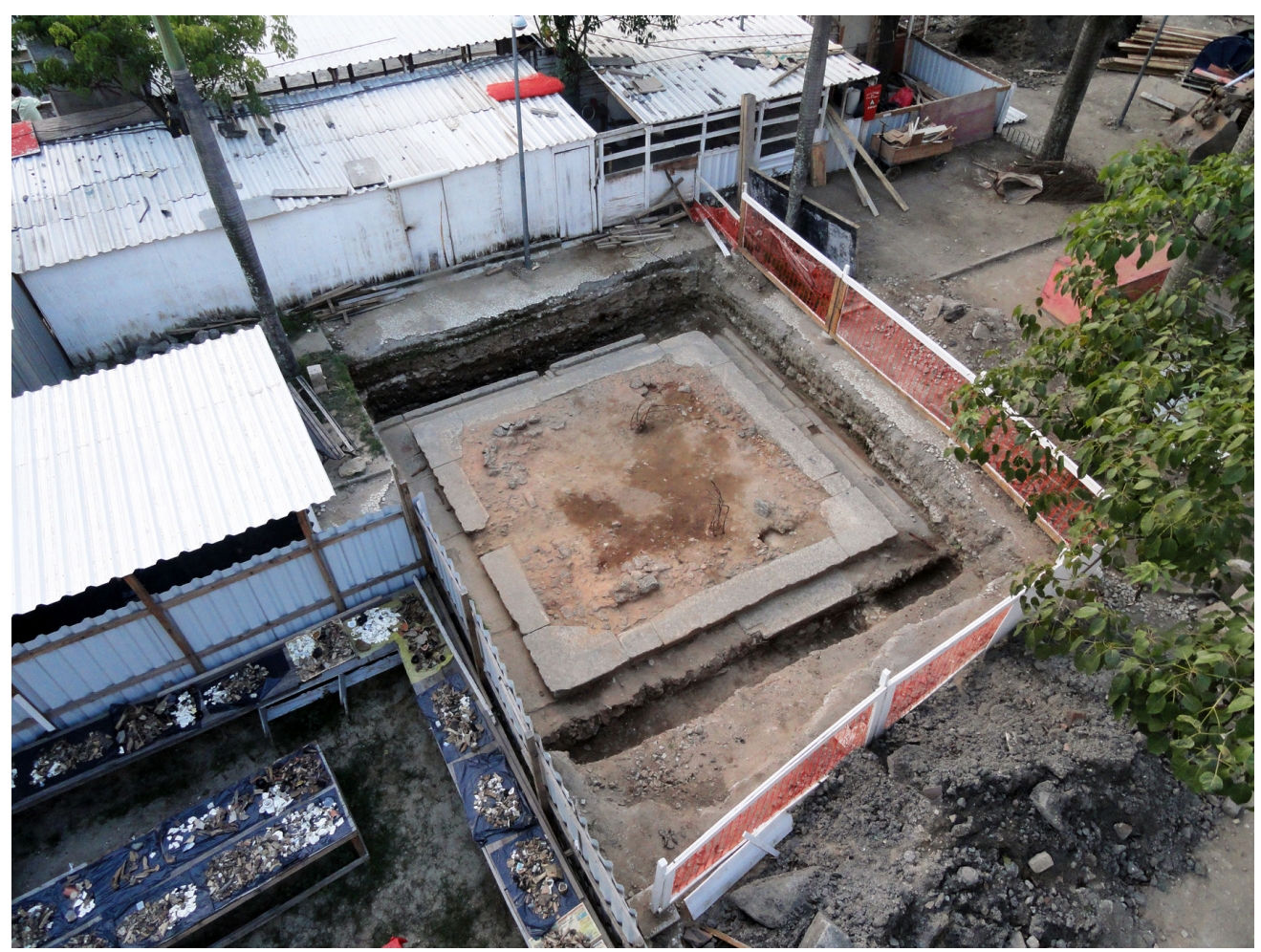

Figura 60 - Os remanescentes do chafariz da Praça Municipal encontrados na Frente 5. 
No miolo dessa estrutura, preenchido apenas com sedimento, foram expostos dois conjuntos descentrados de quatro vergalhões cada, que aparentemente se destinavam a sustentar a peça que ocupava a porção central do chafariz, sobre a qual nada se sabe. Com o objetivo de se avaliar a fertilidade arqueológica do sedimento que compõe hoje em dia o interior da estrutura, foram feitas quatro tradagens com cerca de 0,25 m de diâmeto e profundidade variável - atingindo, em seu limite máximo, 1,20 m. Essas sondagens se revelaram totalmente estéreis do ponto de vista arqueológico.

A estrutura remanescente foi encontrada consideravelmente danificada. $\mathrm{Na}$ face sul do degrau inferior restou apenas uma lajota de granito, tendo desaparecido todas as demais, assim como o bordo elevado. Há outras peças faltantes nas demais faces, tanto lajotas quanto bordos. A moldura superior, contudo, está em melhores condições e apenas uma pedra foi retirada, na altura aproximada à do ralo existente no nível inferior. Grande parte das lajotas apresenta lascamentos e fraturas nas suas bordas externas. Seu mau estado de conservação não justificou que essa estrutura permanecesse exposta, de tal forma que, uma vez escavada e devidamente registrada, ela foi recoberta com o geotêxtil nãotecido bidim, seguido de areia clara, e novamente enterrada, permanecendo assim preservada e protegida no subsolo.

De volta à Frente 1

Em virtude da necessidade de se abrir outra trincheira, ao longo da Frente 1 e paralelamente à galeria de águas pluviais, destinada à passagem de dutos kanaflex para proteção de cabos subterrâneos de energia elétrica, a equipe de arqueologia retornou a essa frente. Correndo à margem da praça, essa trincheira começou a ser escavada no sentido sul/norte, partindo da beira do antigo cais para dentro. Medindo inicialmente 1,30 $\mathrm{m}$ de largura, atingiu a largura máxima de 3,70 m no decorrer da escavação, e 1,80 m de profundidade máxima, e se estendido até próximo à esquina da rua Sacadura Cabral, quando alcançou 103,50 m de comprimento total. A estratigrafia mostrou-se perturbada ao longo dessa trincheira, do lado da rua, em decorrência da passagem anterior de uma tubulação de águas pluviais; porém bem conservada e íntegra, do lado do meio-fio da praça. Nela, foi detectado o limite lateral do Cais do Valongo, à esquerda, e, bem abaixo dele, entre 2,0 e 3,0 m de profundidade, a camada de sedimento muito escuro, lamoso, com abundância de piaçava, correspondente à antiga drenagem natural.

O calçamento do Cais do Valongo apareceu a 18,00 m de distância do cais. Logo em seguida interrompido em uma extensão de $6,50 \mathrm{~m}$, ele reapareceu ao longo de 17,00 m, com profundidades variando entre 1,60 e 1,80 m. Não foi necessário interferir nesse calçamento para passar os dutos e ele pôde ser preservado, tendo sido recoberto com tela fachadeira e areia lavada (Figura 61). 


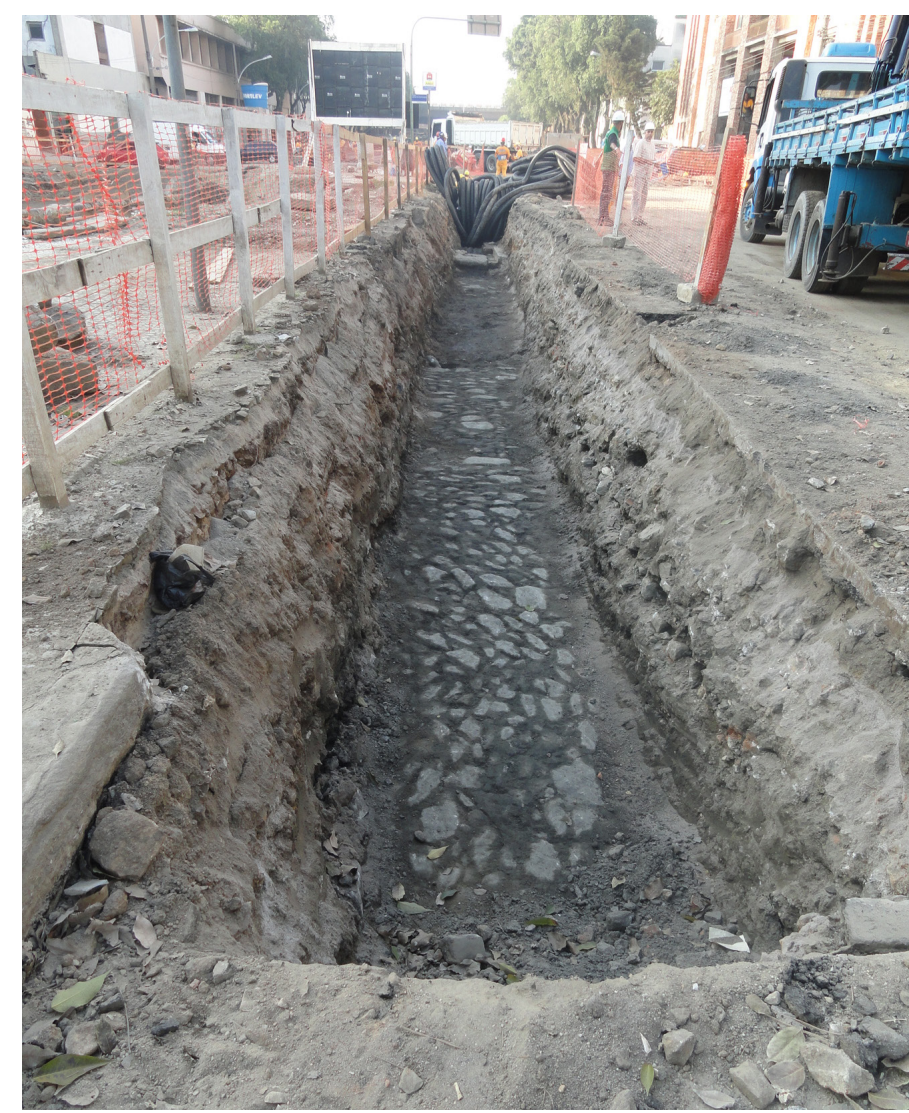

Figura 62 - Ao fundo, a interrupção do calçamento do Valongo na trincheira, seguido de um novo segmento onde ele reapareceu preservado.

Mais adiante, em segmento equivalente aos trechos 7 a 14 da galeria de águas pluviais, foi encontrada uma parte preservada do calçamento do Cais da Imperatriz, com profundidades variando entre $0,60 \mathrm{~m}$ e 0,80 $\mathrm{m}$, em virtude do declive em direção ao mar, em uma extensão tołal de $46,40 \mathrm{~m}$. $\bigcirc$ calçamento aí apareceu razoavalmente íntegro, apresentando apenas algumas falhas por conta de perturbações recentes (Figura 62).

Em dois segmentos onde ele apareceu incompleto, foram realizadas oportunisticamente duas sondagens junto à parede norte da trincheira (do lado da praça), medindo $1,0 \times 1,0 \mathrm{~m}$, sendo a primeira localizada na altura do trecho 6 , e a segunda, a 6,50 m da anterior, em direção à rua Sacadura Cabral. Essas sondagens começaram do nível do calçamento do Cais da Imperatriz, à profundidade de 0,80 m. Em S1, o calçamento do Valongo foi encontrado a 1,20 $\mathrm{m}$ de profundidade. Em S2, escavada até $1,60 \mathrm{~m}$ de profundidade, não foram encontrados seus vestígios. Uma terceira sondagem, S3, medindo também 1,0 $\mathrm{x}$ 1,0 m, foi feita em frente ao n 107 da avenida Barão de Tefé, tendo sido escavada até 1,60 m de profundidade, a partir do calçamento da Imperatriz, mas tampouco aí foi observada a presença do calçamento do Valongo. 


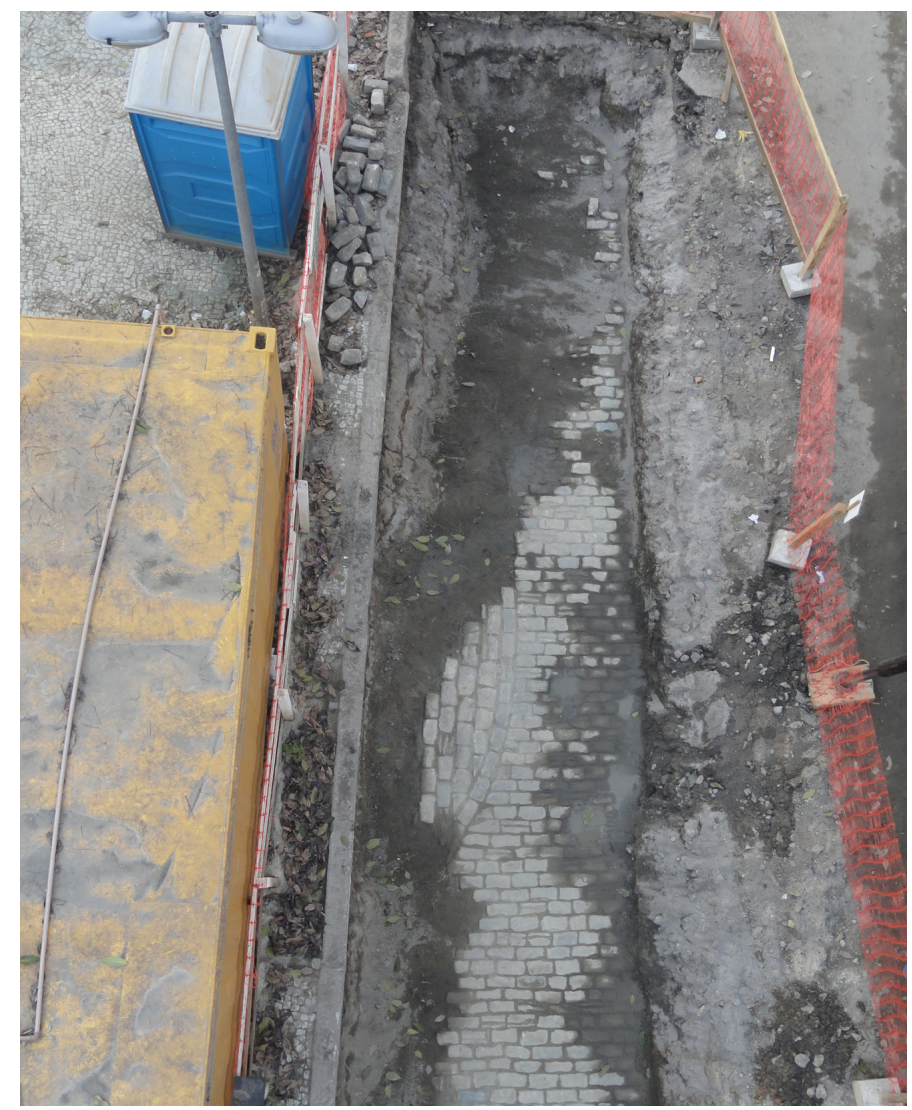

Figura 62 - Segmento preservado do calçamento do Cais da Imperatriz na trincheira paralela da Frente I, na altura entre os Trechos 7 e 14.

Em virtude da necessidade de se remover o calçamento do Cais da Imperatriz para a passagem dos dutos kanaflex, ele foi totalmente exposto, limpo e documentado, tendo sido seus paralelos retirados e guardados.

Com sua remoção e o aprofundamento das escavações na área equivalente também aos Trechos 7 a 14, foi encontrado em parte dela 0 calçamento do Cais do Valongo, entre 1,40 m e 1,60 m de profundidade, diferença decorrente do declive em direção ao mar. Na porção correspondente aos Trechos 7 e 8, o calçamento estava bem preservado a 1,60 m de profundidade (Figura 63).

Na área equivalente ao Trecho 9, não foram encontrados seus vestígios, possivelmente retirados por ocasião da passagem anterior de outros dutos. No segmento correspondente ao Trecho 10, ele apareceu ainda bem preservado, a cerca de 1,40 m de profundidade, em um aclive em direção à rua Sacadura Cabral.

Foram registrados dois perfis estratigráficos nessa trincheira: um, correspondendo ao Trecho 7 da galeria de águas pluviais; e outro, ao Trecho 10 (Figuras 64 a 66). 


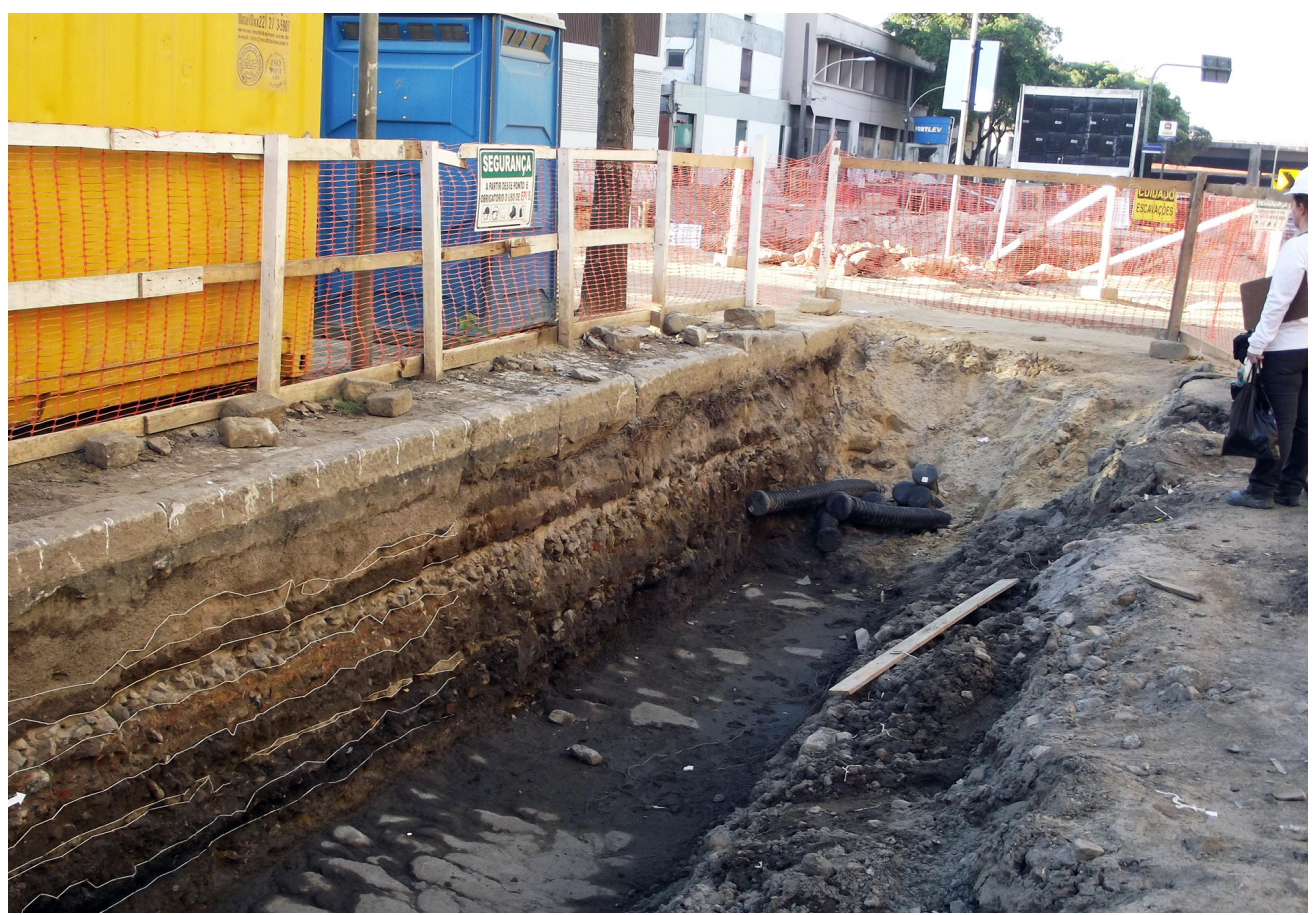

Figura 63 - $O$ calçamento do Cais do Valongo aparecendo bem preservado na trincheira paralela da Frente 1, a 1,60 m de profundidade, na altura dos Trechos 7 e 8.

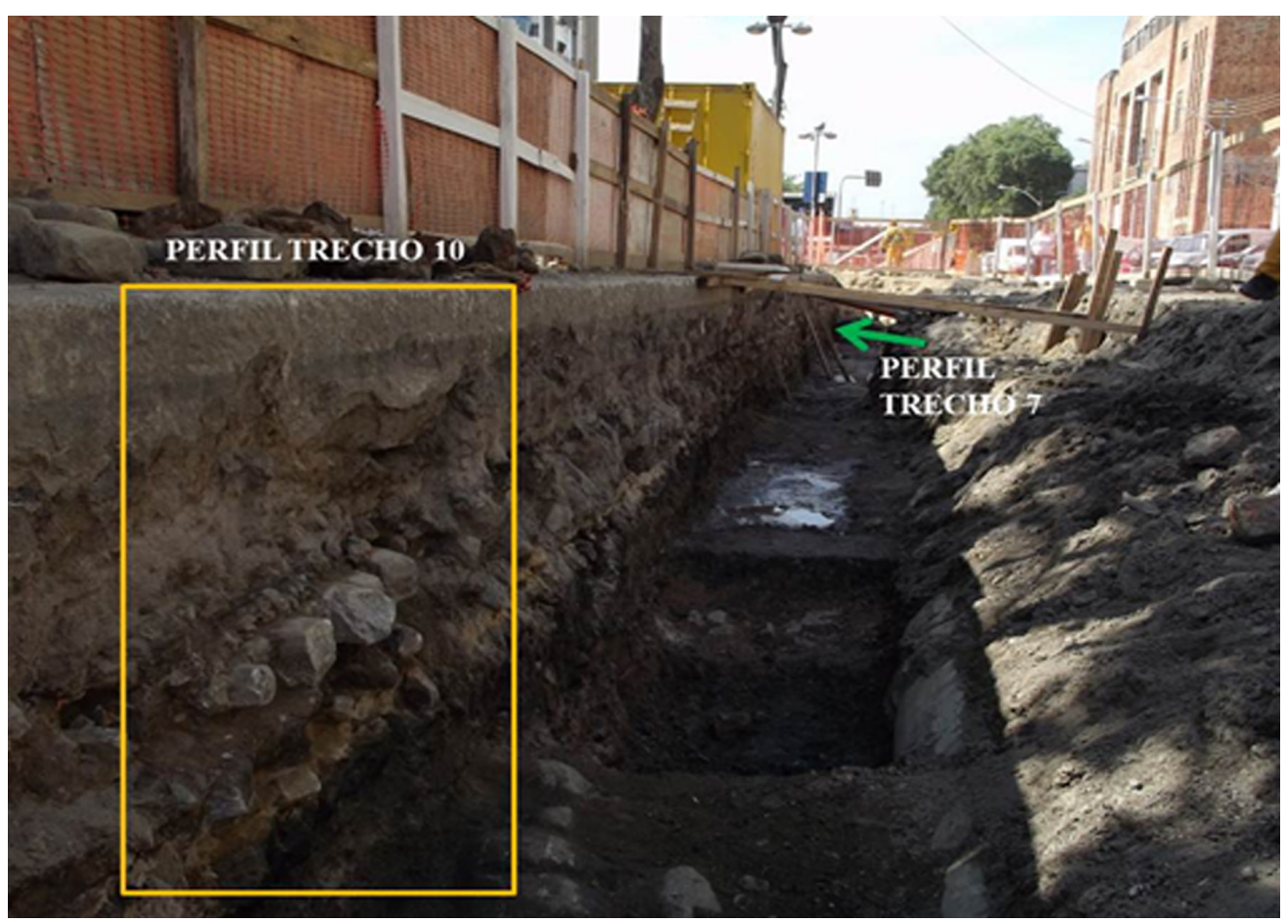

Figura 64 - Localização dos perfís na trincheira paralela da Frente 1, correspondendo aos Trechos 7 e 10 da galeria de águas pluviais. 

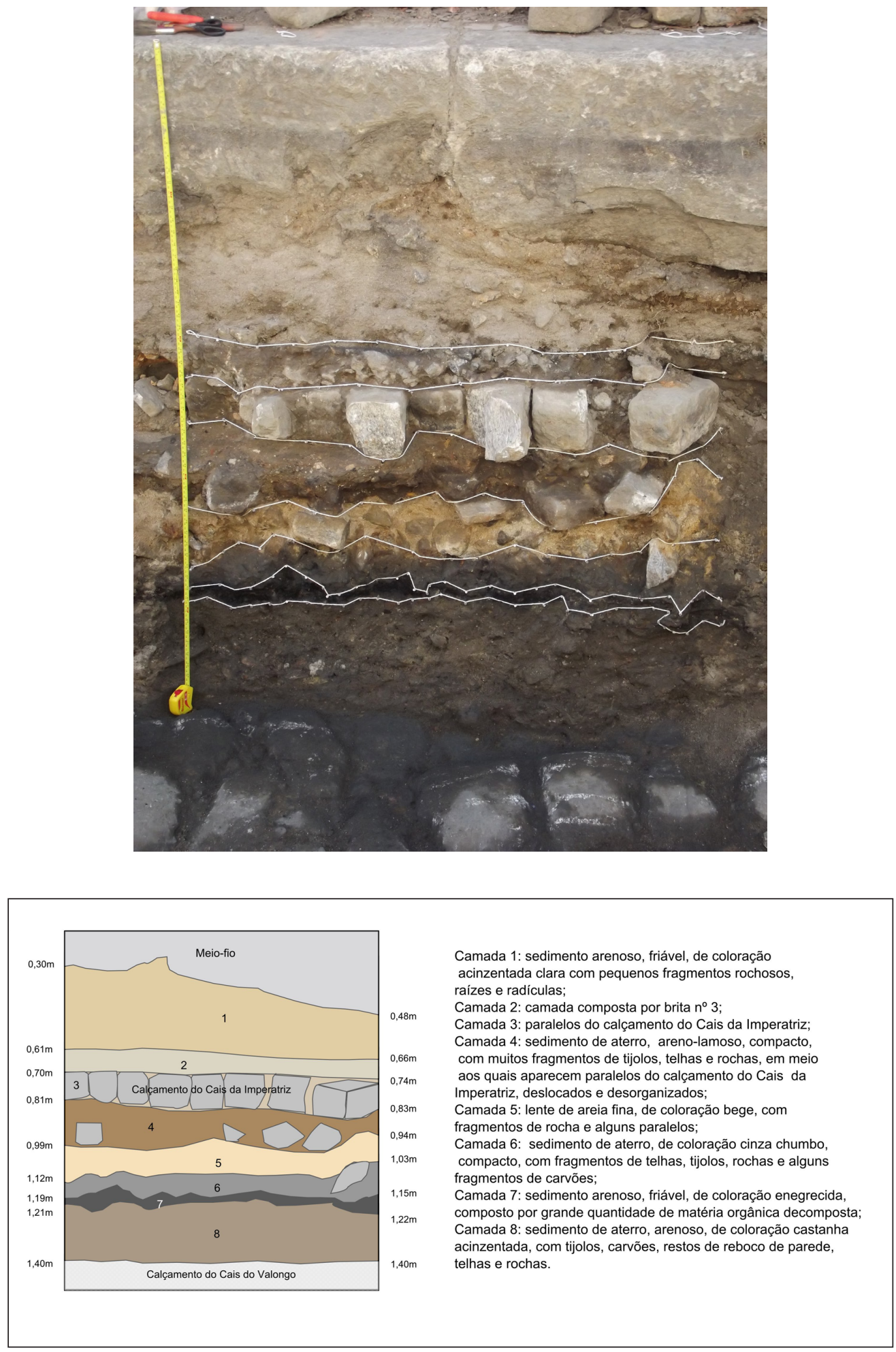

Figuras 65 e 66 - Perfil estratigráfico exposto na trincheira paralela da Frente 1, na altura do Trecho 10. Desenho do perfil: Glaucia Malerba Sene e Andrea Jundi Morgado. Vetorização: Lucas Araújo Costa 
Ao lado da área onde foi feito o perfil estratigráfico correspondente ao Trecho 10 da galeria de águas pluviais, em um pequeno segmento onde o calçamento do Valongo estava interrompido, foi feita oportunisticamente, abaixo do nível dele, uma sondagem que possibilitou atingir maior profundidade. Medindo 3,00 × 1,00 m, nela foi possível observar a seguinte estratigrafia, em sequência à exposta acima - onde a presença do calçamento do Cais do Valongo não tinha permitido seu aprofundamento: entre 1,40 - 1,60 m, sedimento areno-argiloso, acastanhado escuro, com presença de material arqueológico; entre 1,60 - 1,90 m, sedimento argiloso, avermelhado, homogêneo, com muitos blocos rochosos, sem material arqueológico, tratandose claramente de uma camada de preparação para o calçamento; entre 1,90 - 2,30 m: sedimento acinzentado, areno-argiloso, sem material arqueológico até $2,20 \mathrm{~m}$; entre $2,30-3,0 \mathrm{~m}$, sedimento escuro, lamo-arenoso, com muita piaçava, formando camadas espessas e quase intransponíveis para as ferramentas de escavação manual, com presença de materiais arqueológicos (Figuras 67 a 71 ).

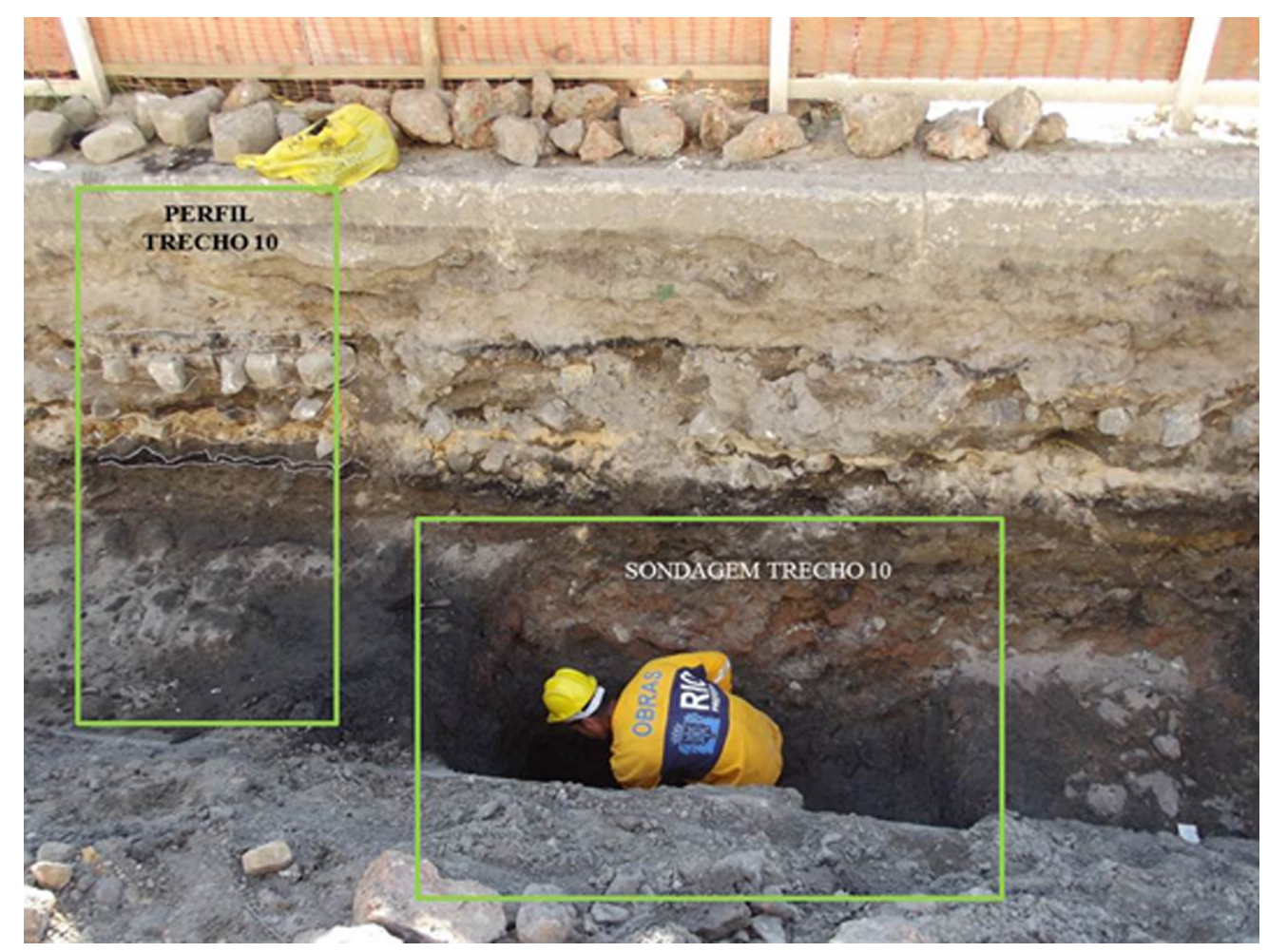

Figura 67 - Localização da sondagem em relação ao perfil escavado, correspondente ao Trecho 10 da galeria de águas pluviais, que possibilitou investigar a sequência estratigráfica abaixo do nível do Cais do Valongo. 


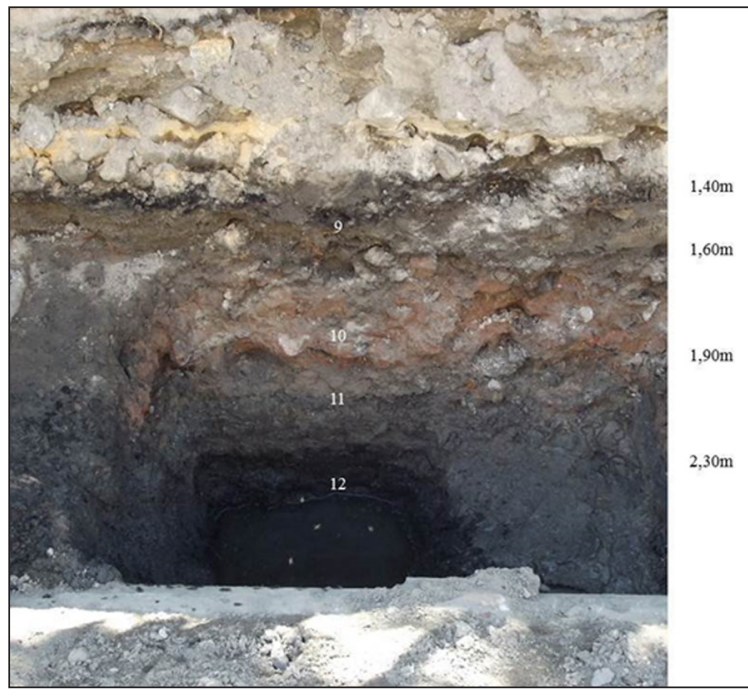

Figura 68 - Estratigrafia da sondagem feita ao lado do perfil exposto na altura do Trecho 10 da Frente 1

Figuras 70 e 71 - Perfil exposto na trincheira paralela, na altura correspondente ao Trecho 7 da Frente 1, com o calçamento do Cais do Valongo na base, sucedido por diferentes níveis de aterro, estando ausente o calçamento do Cais da Imperatriz neste segmento. Desenho do perfil: Glaucia Malerba Sene e Andrea Jundi Morgado. Vetorização: Lucas Araújo Costa

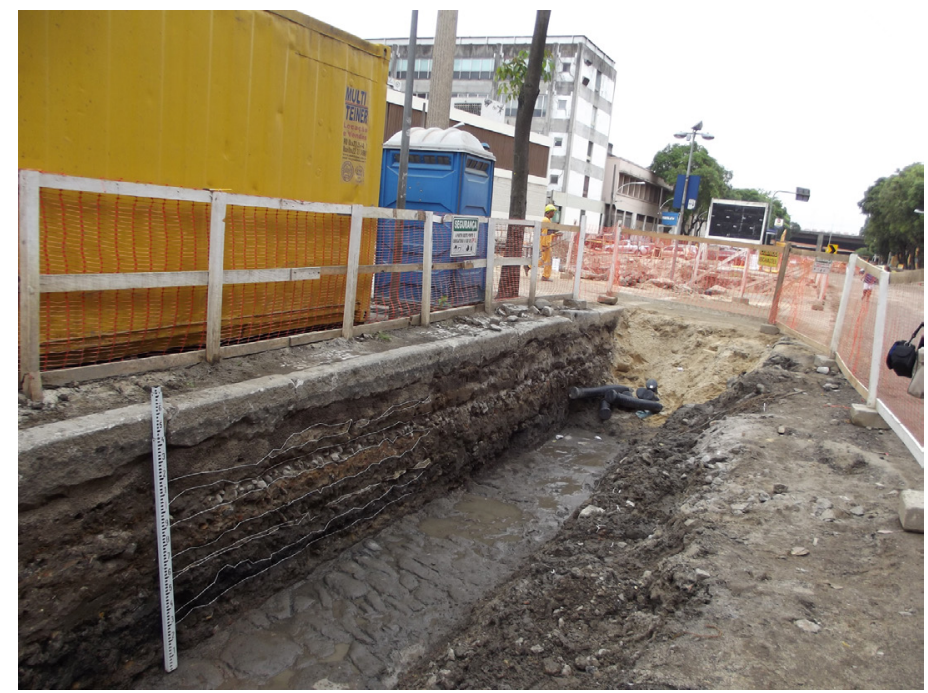

Figura 69 - Localização do perfil feito na trincheira paralela da Frente 1, na altura correspondente ao Trecho 7 .

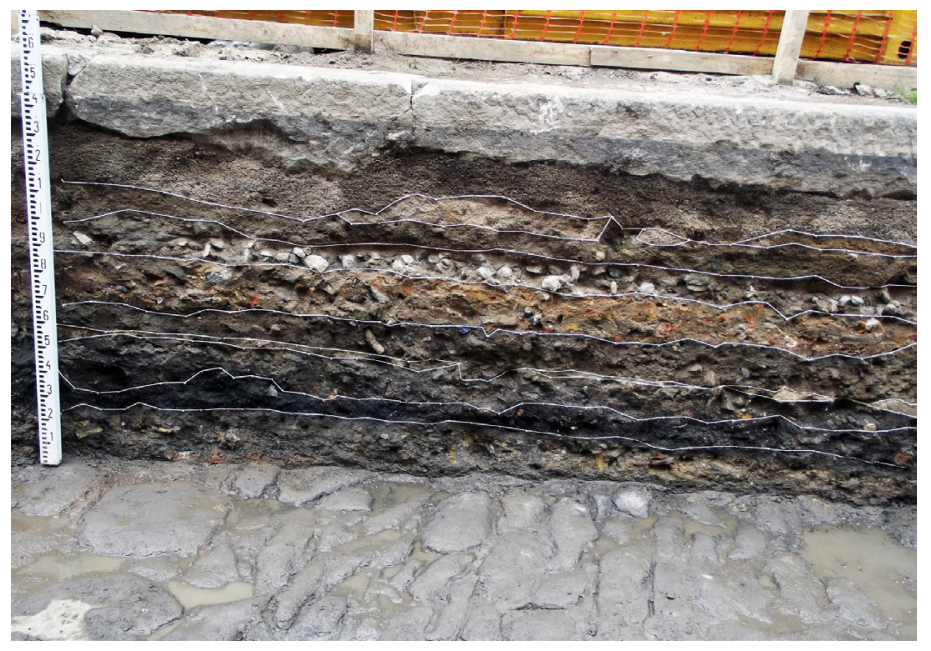

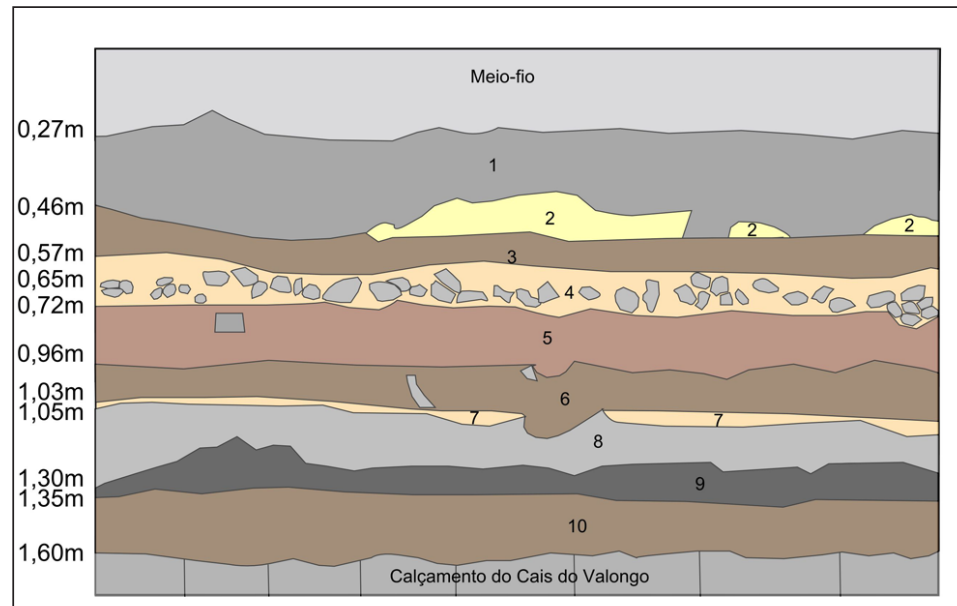

Camada 1: sedimento arenoso, friável, de coloração acinzentada clara, com pequenos fragmentos rochosos,radículas e raizes. Sem vestígios arqueológicos Camada 2: sedimento arenoso, friảvel, de coloração amarelada com presença $0,30 \mathrm{~m}$ de radículas. Sem vestigios arqueológicos

Camada 3: sedimento arenoso, friàvel, de coloração acastanhada, com radiculas, fragmentos de tijolos e poucos fragmentos rochosos variando entre $1 \mathrm{e} 3 \mathrm{~cm}$. Sem vestígios arqueológicos;

$0,46 \mathrm{~m}$ Cam vestígios arqueológicos; $0,46 \mathrm{~m}$ Camada 5: sedimento areno-lamoso de aterro, compacto, de coloração castanho $0,62 \mathrm{~m}$ fragmentos de tijolos, rochas, telhas, em meio aos quais aparecem fragmentos de paralelos do calçamento do Cais da Imperatriz. Começam a aparecer vestigios $0,79 \mathrm{~m}$ arqueológicos:

Comada 6:sedimento arenoso de aterro, fríável, de coloração acastanhada, com fragmentos de metal, rochas e alguns tijolos e telhas. Presença de vestígios 0,96m arqueológicos

Camada 7: areia fina de coloração bege, friável. Sem vestigios arqueológicos:

$1,12 \mathrm{~m}$ Camada 8: sedimento de aterro, de coloração cinza chumbo, compacto e com

$1,16 \mathrm{~m}$ fragmentos de telhas, tijolos, rochas e alguns fragmentos de carvōes.

$1,26 \mathrm{~m}$ Camada 9: sedimento arenoso, friável de coloração enegrecida, composto $1,37 \mathrm{~m}$ por grande quantidade de matéria orgânica decomposta, com fragmentos de tijolos e grande concentração de material arqueológico:

Camada 10:sedimento arenoso, de coloração castanho-acinzentada, com ocorrência de material arqueológico. 
No segmento correspondente ao limite entre os Trechos 10 e 11 , a trincheira foi alargada. A antiga (e ainda ativa) tubulação de águas pluviais substituída pela nova galeria foi completamente exposta. Essa antiga rede destruiu parte do calçamento do Cais do Valongo, mas do outro lado da tubulação ele foi preservado, ali tendo sido encontrada sua borda lateral. Nessa ampliação, o calçamento mediu $3,60 \mathrm{~m}$ de largura nesse segmento, desde a sua borda até o meio-fio da praça. Foi feito um arremate de pedras retangulares no calçamento, algumas com até $0,85 \mathrm{~m}$ de comprimento, delimitando-o (Figura 72).

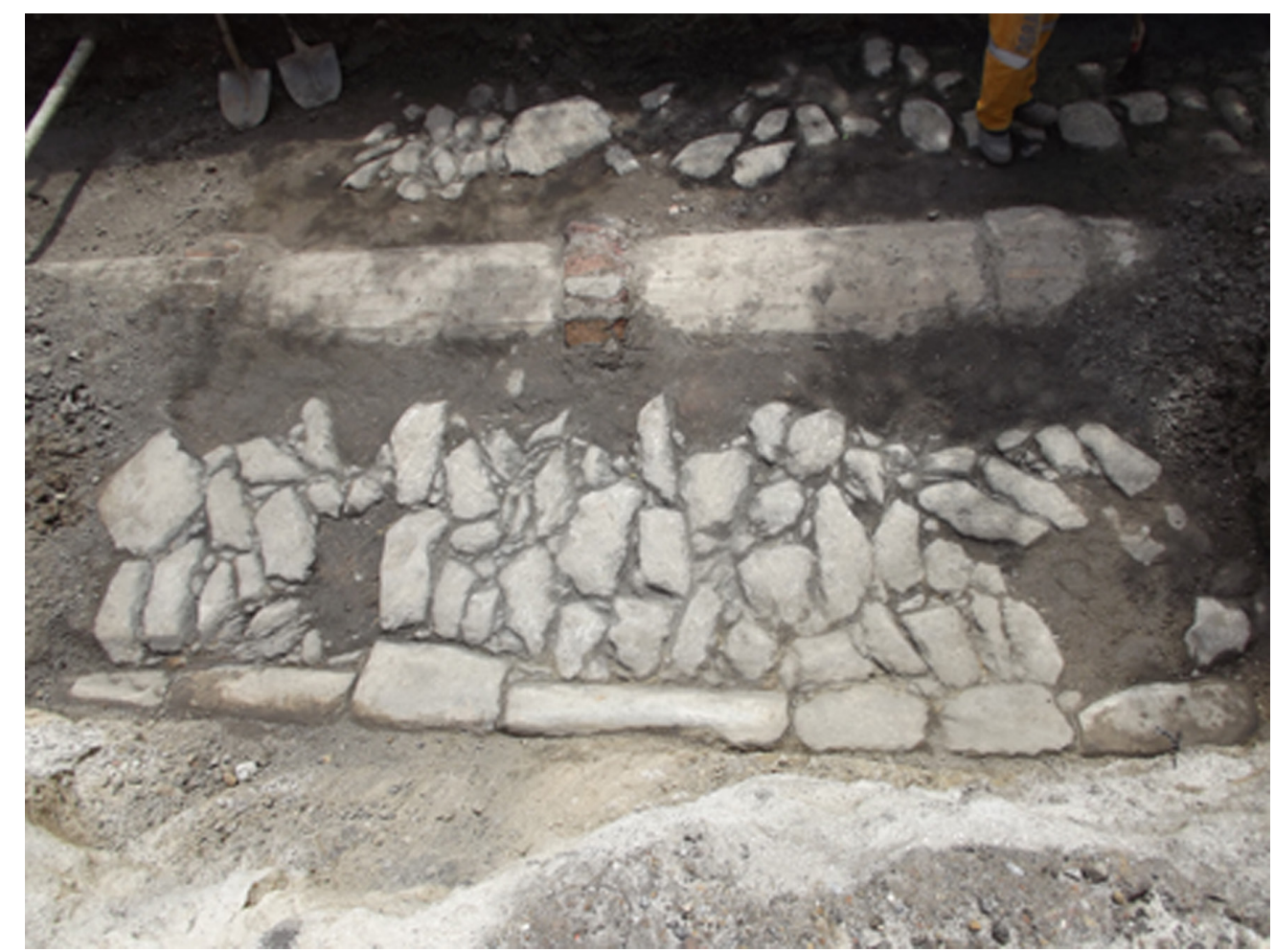

Figura 72 - A manilha que danificou o calçamento do Cais do Valongo no segmento correspondente ao limite entre os Trechos 10 e 1 1, e o arremate que o delimita, compondo uma borda.

Nos segmentos equivalentes aos Trechos 11, 12 e 13, a profundidade alcançada pela escavação variou entre 1,55 m (profundidade final do Trecho 1 1) e 1,70 m (profundidade final dos Trechos 12 e 13). Nesses trechos mais profundos, foi necessário proceder a um preenchimento com areia lavada para o nivelamento final em $1,60 \mathrm{~m}$, profundidade estipulada para a colocação dos dutos kanaflex. No Trecho 1 1, o calçamento do Valongo foi interrompido de forma súbita, tratando-se claramente de um segmento destruído, a 1,40 m de distância de um tubo de ferro que se encontrava a $1,10 \mathrm{~m}$ de profundidade, estando ele mesmo um pouco mais profundo, a 1,40 m (Figura 73). A escavação prosseguiu até $1,55 \mathrm{~m}$, na tentativa de se encontrar sua 
continuação ou seu arremate terminal, mas não foi constatada sua presença além do trecho 11 . Nesse ponto foram observadas várias intervenções recentes: uma tubulação de gás a $0,90 \mathrm{~m}$ de profundidade; uma manilha paralela ao meio-fio e a 1,0 m de distância dele, a 1,30 m de profundidade; e duas tubulações de esgoto instaladas recentemente. Apenas o tubo de ferro pareceu ser mais antigo. Nos segmentos equivalentes aos Trechos 12 e 13 não apareceram vestígios do calçamento do Cais do Valongo, mas foram recuperados materiais arqueológicos.

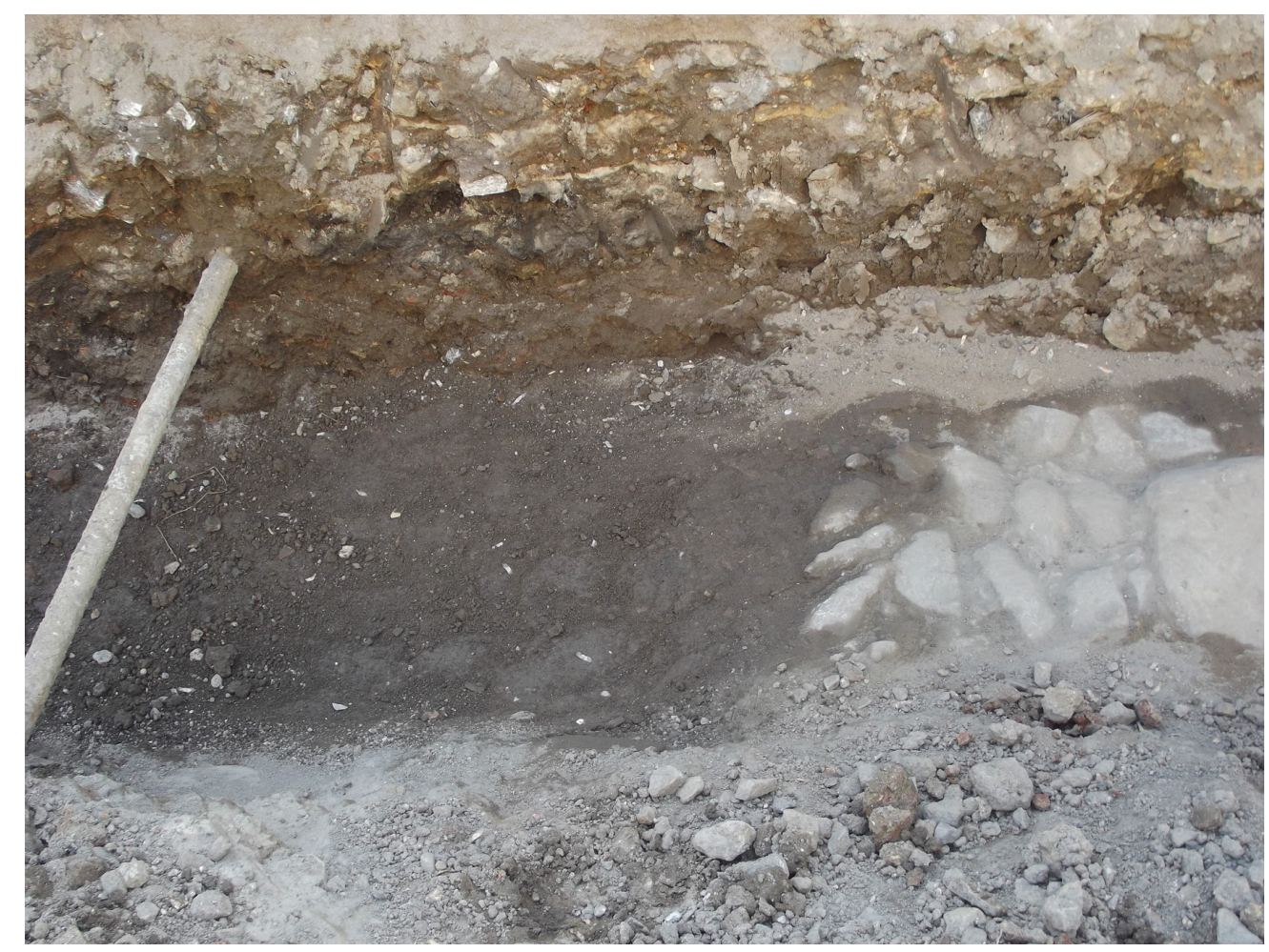

Figura 73 - $\bigcirc$ desaparecimento repentino do calçamento do Valongo no segmento equivalente ao Trecho 11 da galeria de águas pluviais, próximo ao tubo de ferro, sem que tivesse sido encontrado seu arremate ao norte.

O segmento equivalente ao Trecho 14 foi escavado entre 0,60 e 1,60 $\mathrm{m}$ de profundidade, tendo sido recuperados materiais arqueológicos. Na parte equivalente ao Trecho 15, iá próximo à esquina com a rua Sacadura Cabral, a escavação desceu também até $1,60 \mathrm{~m}$, tendo sido verificado alto número de interferências, incluindo a manilha que, nesse ponto, se aproximou da praça, além de tubulações diversas e um envelope de energia elétrica. Se o calçamento do Cais do Valongo se estendeu originalmente até esse ponto, é provável que a antiga galeria de águas pluviais o tenha destruído. Nenhum vestígio arqueológico foi encontrado. O segmento correspondente aos Trechos 7 a 15 da galeria de águas pluviais atingiu 53,00 m de extensão. 
Em decorrência das práticas de descarte de lixo à beira-mar vigentes nos oitocentos, a área em frente ao cais foi escavada, face à alta probabilidade de estar repleta de vestígios dos períodos em que ele funcionou tanto como Cais do Valongo, quanto como Cais da Imperatriz, ao longo portanto de praticamente todo o século XIX.

No trecho correspondente à Frente 2, foi feita inicialmente a escavação mecânica de uma faixa de 10,0 m de largura, entre a superfície e 6,00 m de profundidade, com níveis alagados, em busca de objetos descartados ou caídos inadvertidamente no mar (Figura 74). Contudo, essa tarefa só pôde ser realizada em etapas, pois era necessário manter a estabilidade das tubulações de esgoto e gás que passavam pelo local. Por segurança, foi deixada uma faixa de 5,0 m junto às lajotas do cais (Trecho O), e, a partir delas, foram escavados três trechos - 1 , 2 e 3 - com a medida padrão de 5,0 m, a exemplo do que foi adotado para a galeria de águas pluviais da Frente 1. Foram recuperados abundantes vestígios arqueológicos nessa faixa, até a profundidade de 6,0 m - o máximo autorizado pelos engenheiros de segurança da obra -, embora as evidências permitissem supor a presença de materiais arqueológicos em níveis ainda mais profundos. Foi a segunda área mais fértil do sítio arqueológico, em seguida à galeria de águas pluviais da av. Barão de Tefé.

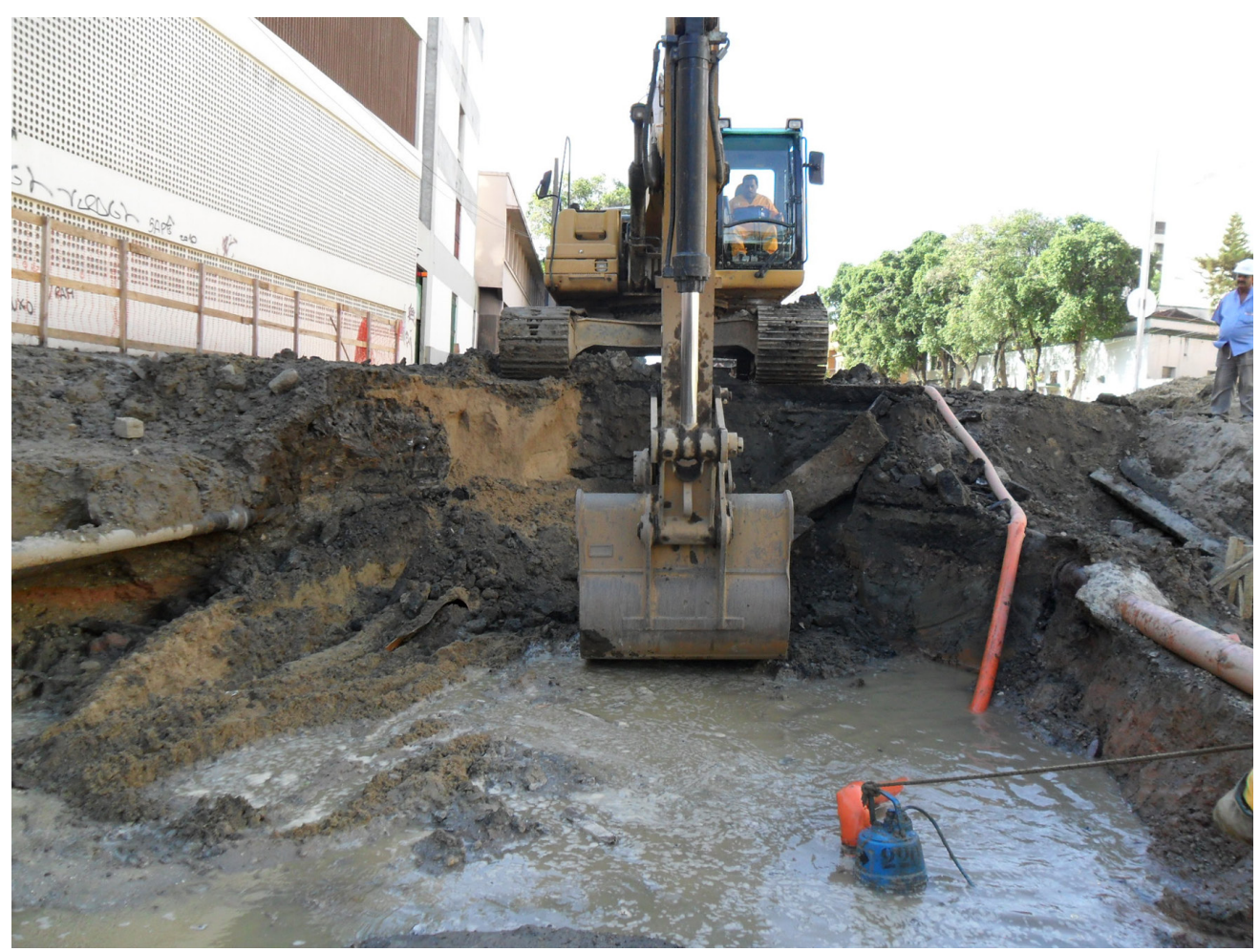

Figura 74 - Escavação mecânica da área em frente ao cais, na Frente 2, Trechos 1, 2, 3. Após a retirada das camadas de aterro, foram escavados mecanicamente os níveis arqueológicos, em parte inundados. 
A partir de $2,0 \mathrm{~m}$ de profundidade começaram a aparecer vestígios, porém entre 4,0 e 6,0 m, surgiu uma camada em declive composta de sedimento areno-lamoso, escuro, com alta concentração de matéria orgânica decomposta, fibras de piaçava e grande quantidade de materiais arqueológicos diversificados, da primeira e segunda metades do século XIX. Todo o sedimento proveniente dessa área foi peneirado. Não foi possível prosseguir a escavação em virtude da presença de diversas redes subterrâneas que tinham que ser remanejadas para viabilizá-la (Figuras 75 e 76).

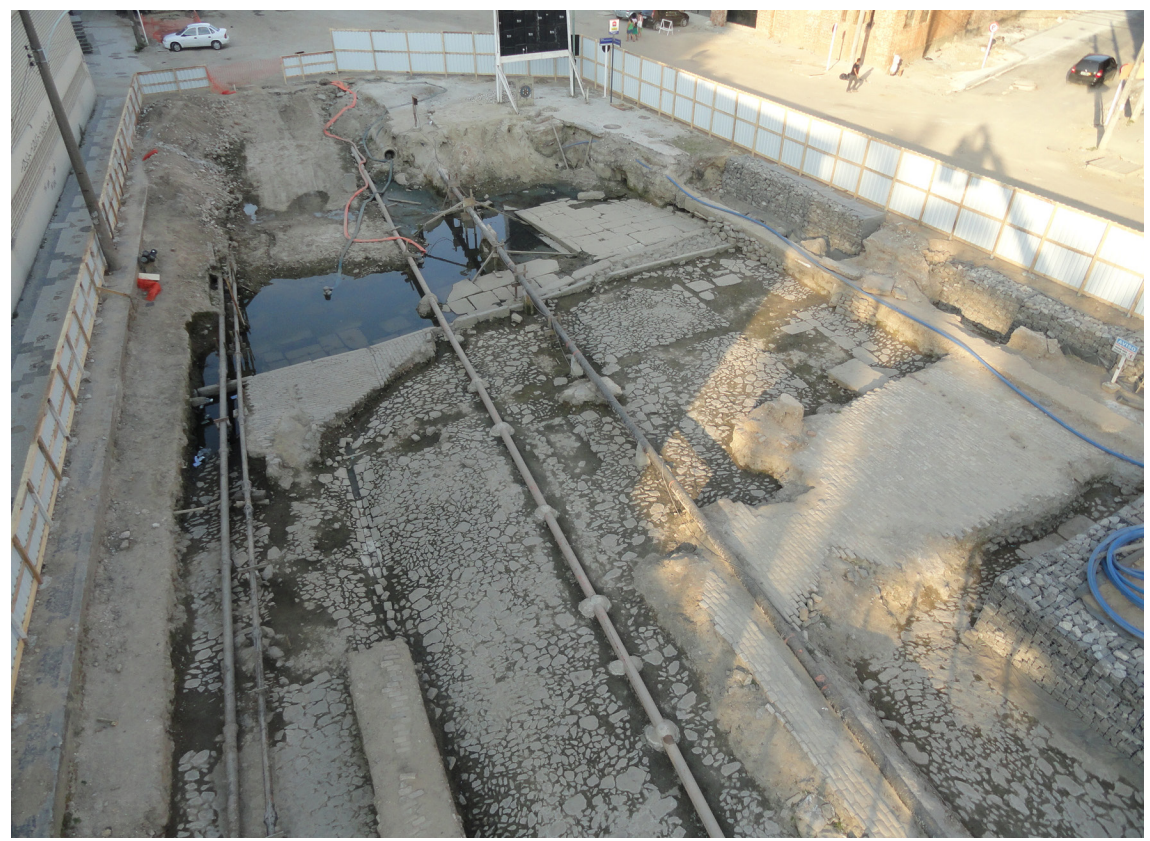

Figura 75 - A área em frente ao cais inundada, com a presença de diferentes redes impedindo a progressão das escavações. Foi preciso aguardar seu remanejamento para que a escavação pudesse prosseguir.

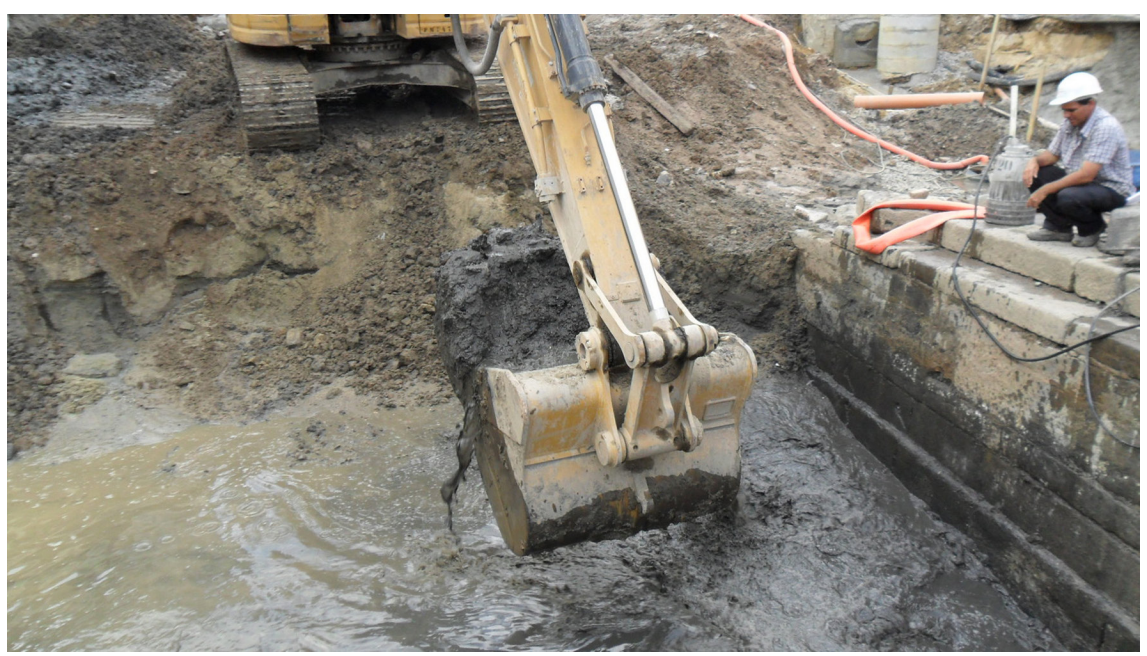

Figura 76 - Escavação mecânica dos níveis alagados da área em frente ao cais. 
Após a complicada e morosa remoção completa dessas redes, para a qual foi necessário esperar precisamente um ano, foram retomadas as escavações mecânica e manual da área fronteira ao cais. Livres das diferentes tubulações, foi possível escavar - Trecho $\mathrm{O}$ da Frente 2, os trechos de $\mathrm{O}$ a 3 do limite entre as Frentes 2 e 3, assim como ampliar e aprofundar a escavação da rampa de lajotas de pedra da Frente 3. Essa escavação expôs a fachada da estrutura edificada do cais na Frentes 2 e no seu limite com a 3 (Figuras 77 a 78), permitindo não apenas o exame do seu sistema construtivo, mas também das avarias por ela sofridas ao longo do século XIX.

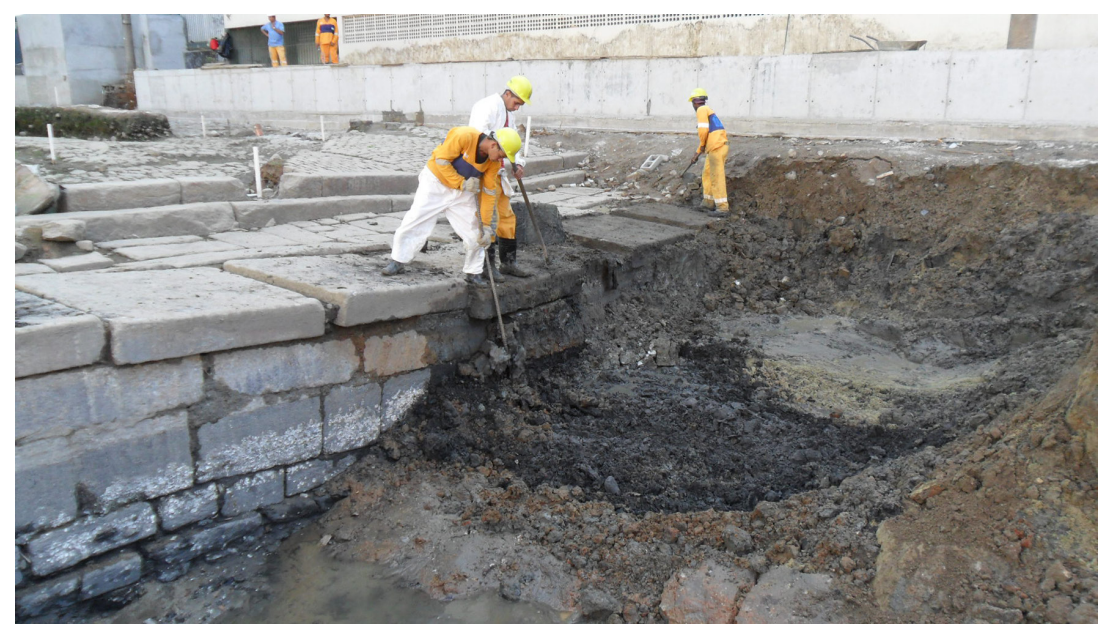

Figura 77 - Exposição progressiva da estrutura edificada do cais na Frente 2.

Figura 78 - Aprofundamento da escavação e exposição progressiva do paredão do cais.

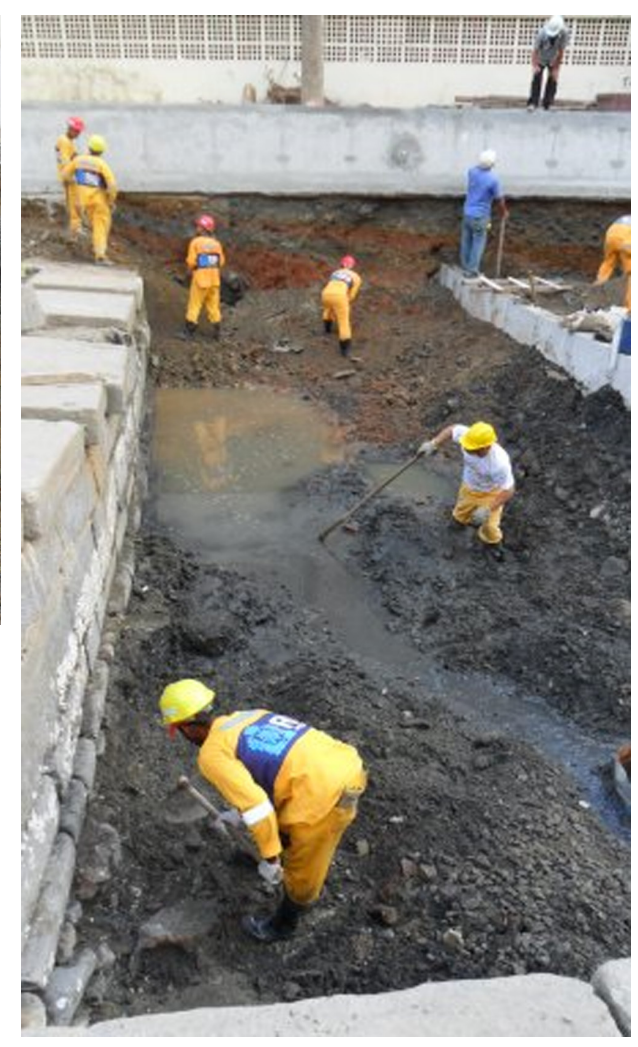

Essa escavação expôs, na parede lateral, um perfil estratigráfico que apresenta, na sua base, a camada arqueológica de sedimento arenoso enegrecido, com muita matéria orgânica decomposta e grande quantidade de vestígios arqueológicos, sucedida por camadas de aterro (Figuras 79 a 82).

Uma ampla escavação, mecânica e manual, expôs progressivamente a rampa de desembarque do Cais da Imperatriz. Cabe destacar mais uma vez que, por baixo dela, encontra-se a do Cais do Valongo, entrevista a partir da observação oportunística do deslocamento de um de seus blocos, já descrita anteriormente. Ao final dessa rampa foram confirmados os degraus, de fato em número de três, e a existência de uma nova superfície rampada (Figura 83). 


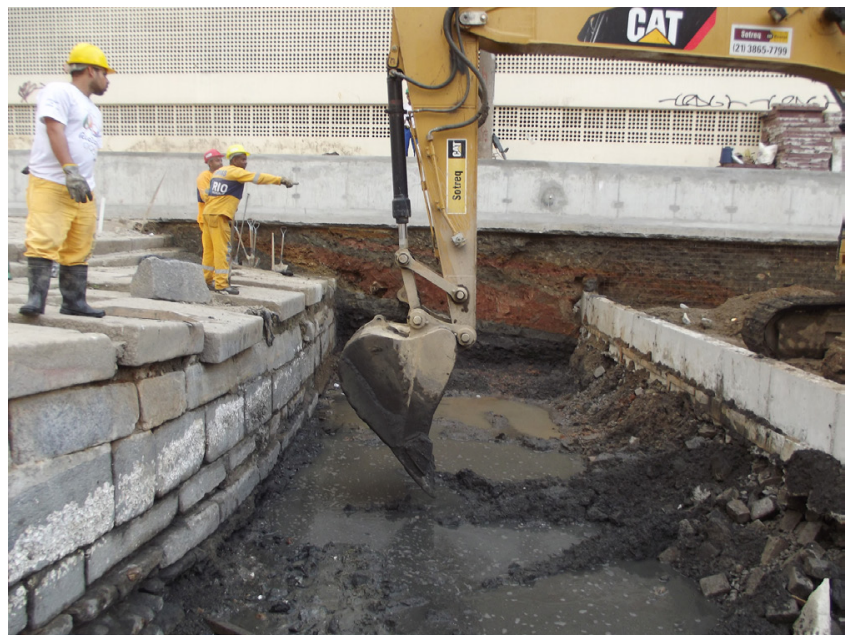

Figura 79 - Aprofundamento da escavação na Frente 2, expondo perfil estratigráfico na parede ao fundo.

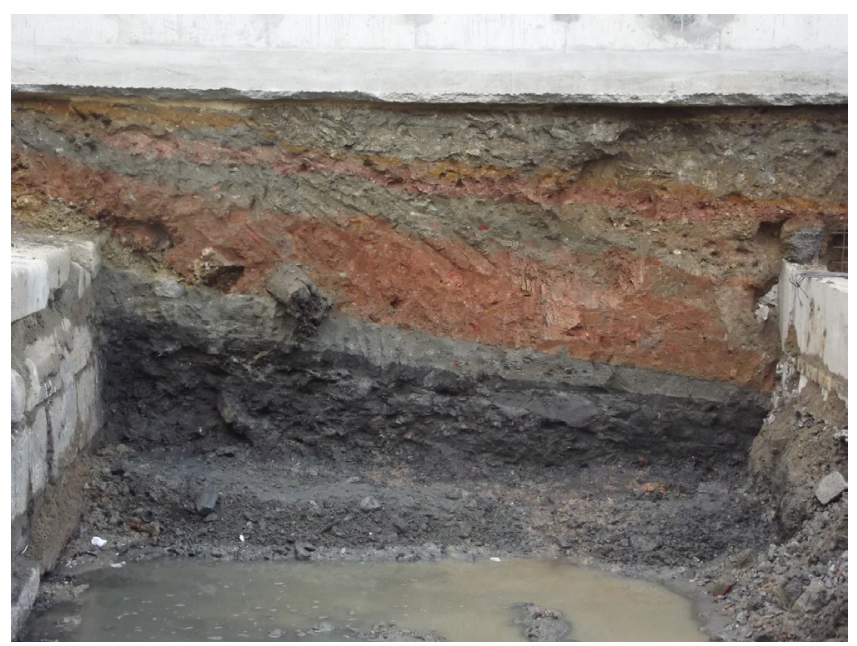

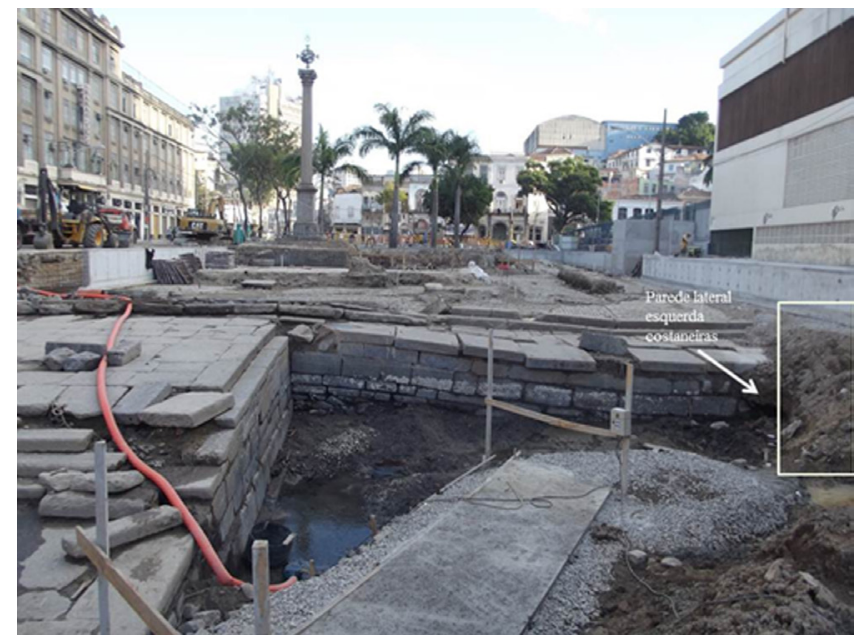

Figura 80 - Localização do perfil estratigráfico

Figuras 81 e 82 - Sob os níveis de aterro, apareceu a camada arqueológica escura no fundo, em declive, com grande concentração de matérias orgânicas e vestígios arqueológicos diversificados. Desenho do perfil: Andrea Jundi Morgado. Vetorização: Lucas Araújo Costa.

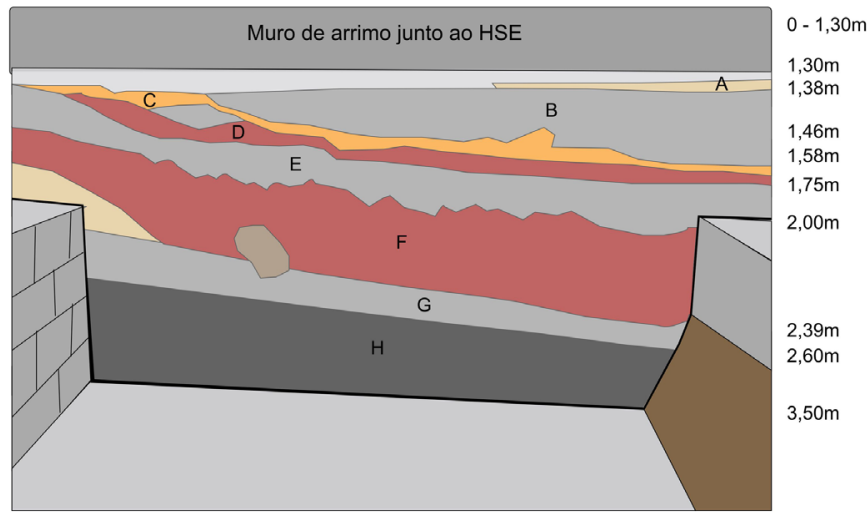

Camada A: sedimento arenoso, de coloração castanha, com pequenos fragmentos rochosos;

Camada B: sedimento lamo-arenoso, de coloração acinzentada, com fragmentos de rocha decomposta; Camada C: sedimento lamoso, de coloração alaranjada;

Camada D: sedimento areno-lamoso, de coloração avermelhada, possivelmente saibro;

Camada E: sedimento lamo-arenoso, de coloração acinzentada, com fragmentos de rocha decomposta; Camada F: sedimento lamoso, de coloração

avermelhada, com fragmentos de tijolos. Presença de bolsão de sedimento areno-lamoso, de aterro, de coloração amarelada e de um tronco de madeira inserido nesta camada;

Camada G: sedimento arenoso, de coloração acinzentada, friável, sem vestígios arqueológicos:

Camada H: sedimento arenoso, de coloração enegrecida, com muita matéria orgânica decomposta e grande quantidade de vestígios arqueológicos. 


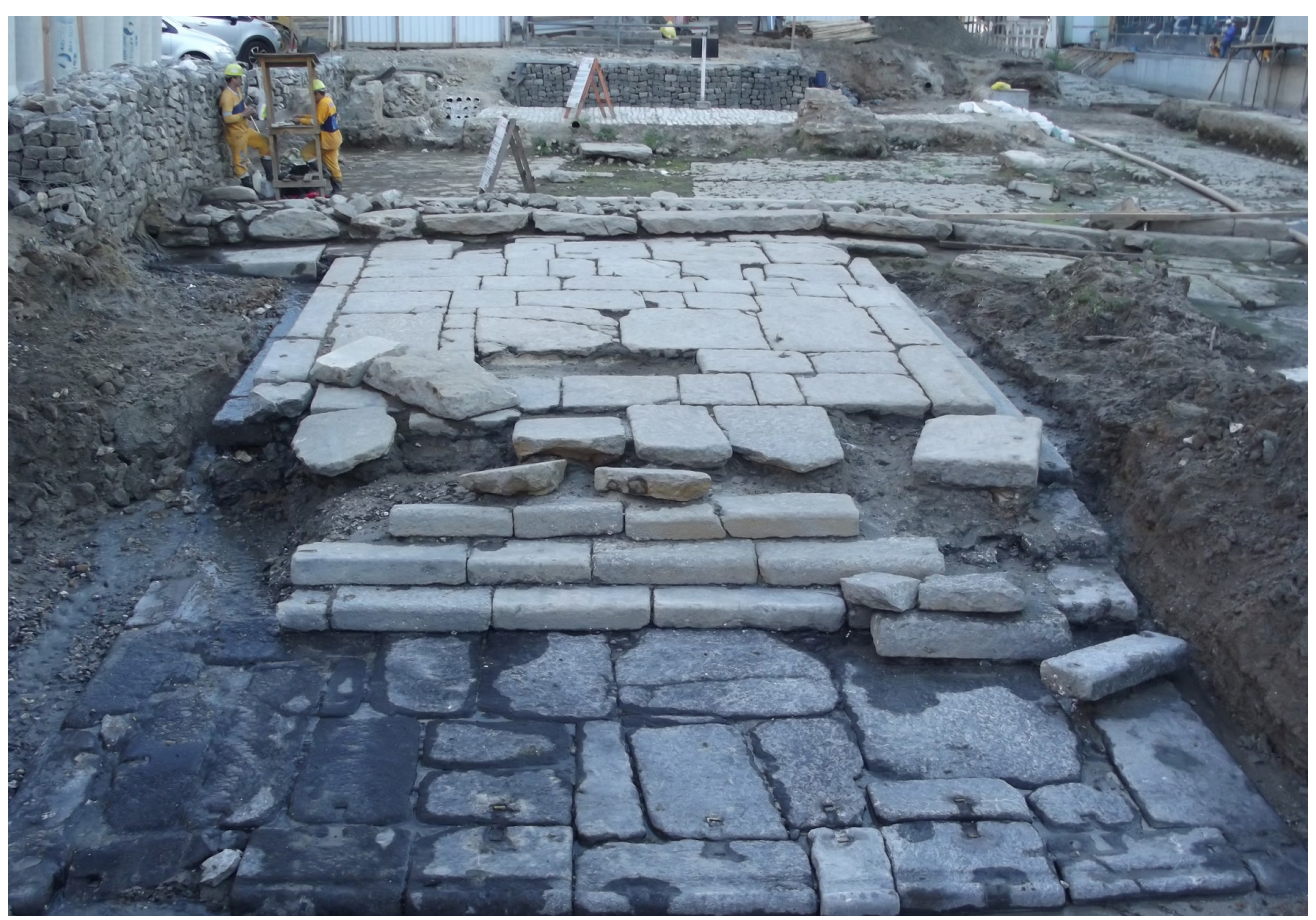

Figura 83 - Exposição das rampas e dos três degraus da escada do Cais da Imperatriz.

A rampa inferior, situada a 2,80 m do nível atual da rua, mede 6,60 $\mathrm{m}$ de largura por 2,90 m de extensão, tendo sido feita com lajotas de diferentes dimensões. A ela seguem-se os três degraus, a 2,0 m de profundidade em relação ao nível do asfalto atual, que mediram respectivamente 0,33, 0,28 e 0,4 1 m de piso e 0,18 $\mathrm{m}$ de espelho. E a rampa superior, a 1,50 $\mathrm{m}$ de profundidade, que mediu 6,10 de largura e 9,80 m de extensão, também feita com blocos de diferentes dimensões. Juntas e somadas, compõem uma superfície de $89 \mathrm{~m} 2$, com 13,50 m de extensão por 6,60 m de largura máxima. Na rampa superior, a última camada de lajotas sobreposta à estrutura, mais estreita que as anteriores, produziu um recuo de 0,35 m em ambos os lados, tendo recebido uma moldura de paralelepípedos retângulos como arremate (ver Figura 83).

Na lateral da rampa, as escavações deixaram à mostra seu sistema construtivo, tendo sido possível observar uma construção ciclópica com alvenaria de pedras arrumadas, de dimensões variadas, porém em sua maioria grandes, empilhadas sucessivamente em oito camadas (Figura 84). Hoje em dia, aparentemente, assentadas a seco, apresentando em sua junção apenas remanescentes do sedimento terroso escavado, elas devem ter sido certamente unidas por argamassa de cal e areia, porém sobre esse elemento nada se sabe. Não há sinais visíveis da sua presença para a fixação desses blocos, embora ela deva ter sido utilizada para essa finalidade, inclusive porque figura no registro documental a necessidade do seu emprego, de modo a fortalecer a estrutura. Contudo, diante das vigorosas investidas do mar, somadas ao grande volume de 
águas pluviais drenadas da superfície terrestre, seus vestígios teriam sido lavados, não restando evidências visíveis das argamassas utilizadas originalmente nessa construção. De todo modo, a julgar pelo mau desempenho que apresentou ao longo do século XIX, constantemente danificada pela força do mar, a argamassa ali utilizada parece ter atuado mais como berço para assentamento dos blocos que propriamente como um elemento destinado a aumentar de fato sua resistência e melhorar sua performance.

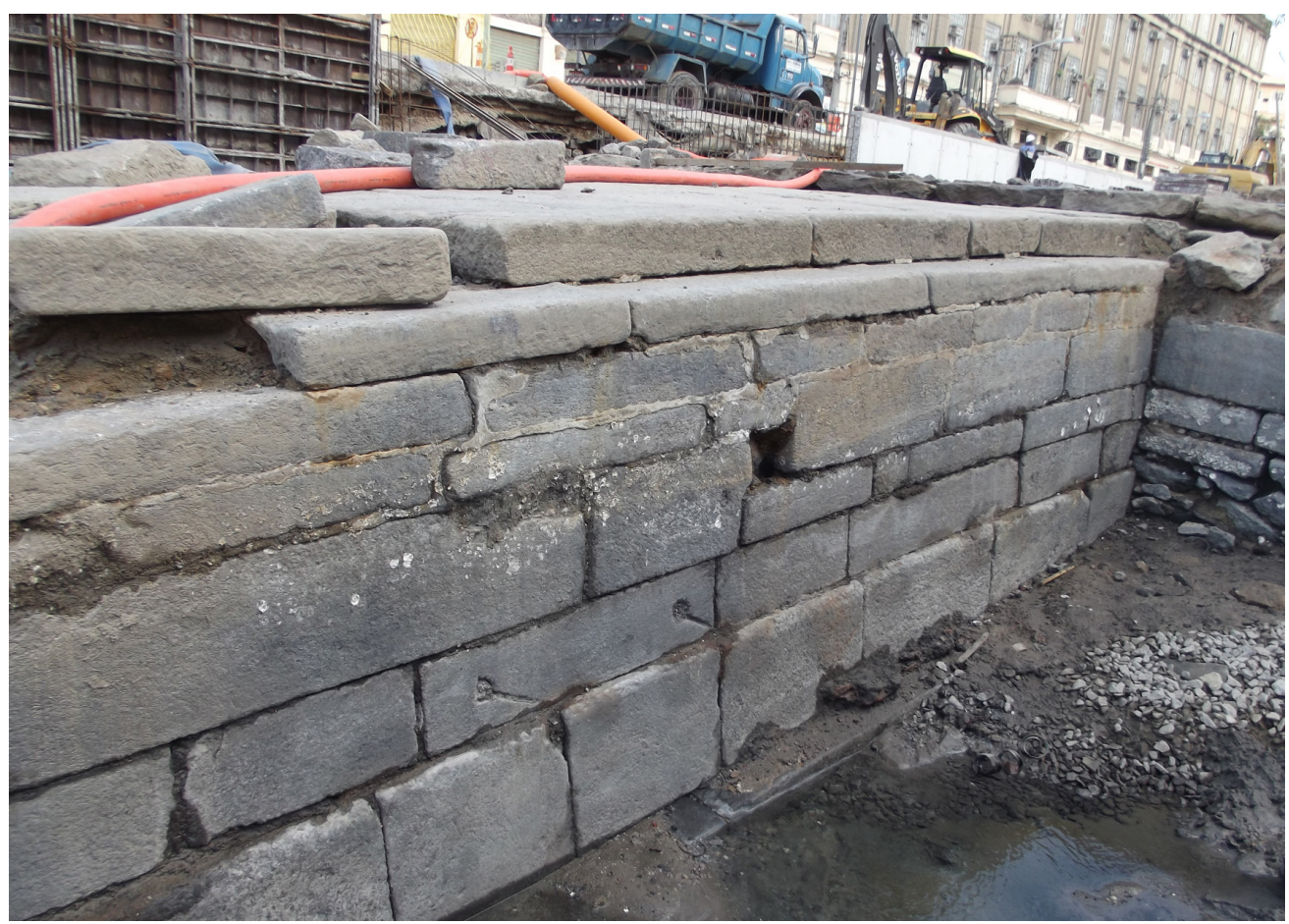

Figura 84 - $\bigcirc$ paredão lateral da rampa do Cais da Imperatriz, com o nível inferior alagado e parcialmente encoberto. Ele mede 2,70 m de altura no seu segmento médio, decrescendo progressivamente em direção ao mar. Na sua base, há um respaldo de cerca de 0,20 m de espessura e 0,55 m de altura, que não foi possível observar em detalhe pelo fato de a área estar permanentemente inundada e os procedimentos adotados para dessecar esse canto terem sido de modo geral mal sucedidos.

Tentativas de reforçar a estrutura com novas argamassas foram feitas em momentos posteriores à sua construção, quando algumas de suas juntas foram grosseiramente emplastradas com diferentes tipos de argamassas ou preenchidas com pedras (Figuras 85 e 86 ).

$\bigcirc$ reaproveitamentos de pedras de outros locais foi uma prática frequente, como consta em resolução da Câmara, datada de outubro de 1842, que autorizou a remoção de pedras dos degraus do antigo pelourinho da cidade, localizado no Campo de Santana, bem como as pilastras de pedra da ponte de São Cristóvão para serem aproveitadas na obra do cais $^{71}$. Algumas lajotas apresentam marcas que atestam essas reutilizações (Figura 87).

Annals of Museu Paulista. v. 24. n.1. Jan.-Abr. 2016.
71. Arquivo Geral da Cidade do Rio de Janeiro. Códice 36.2.4, fl. 86 

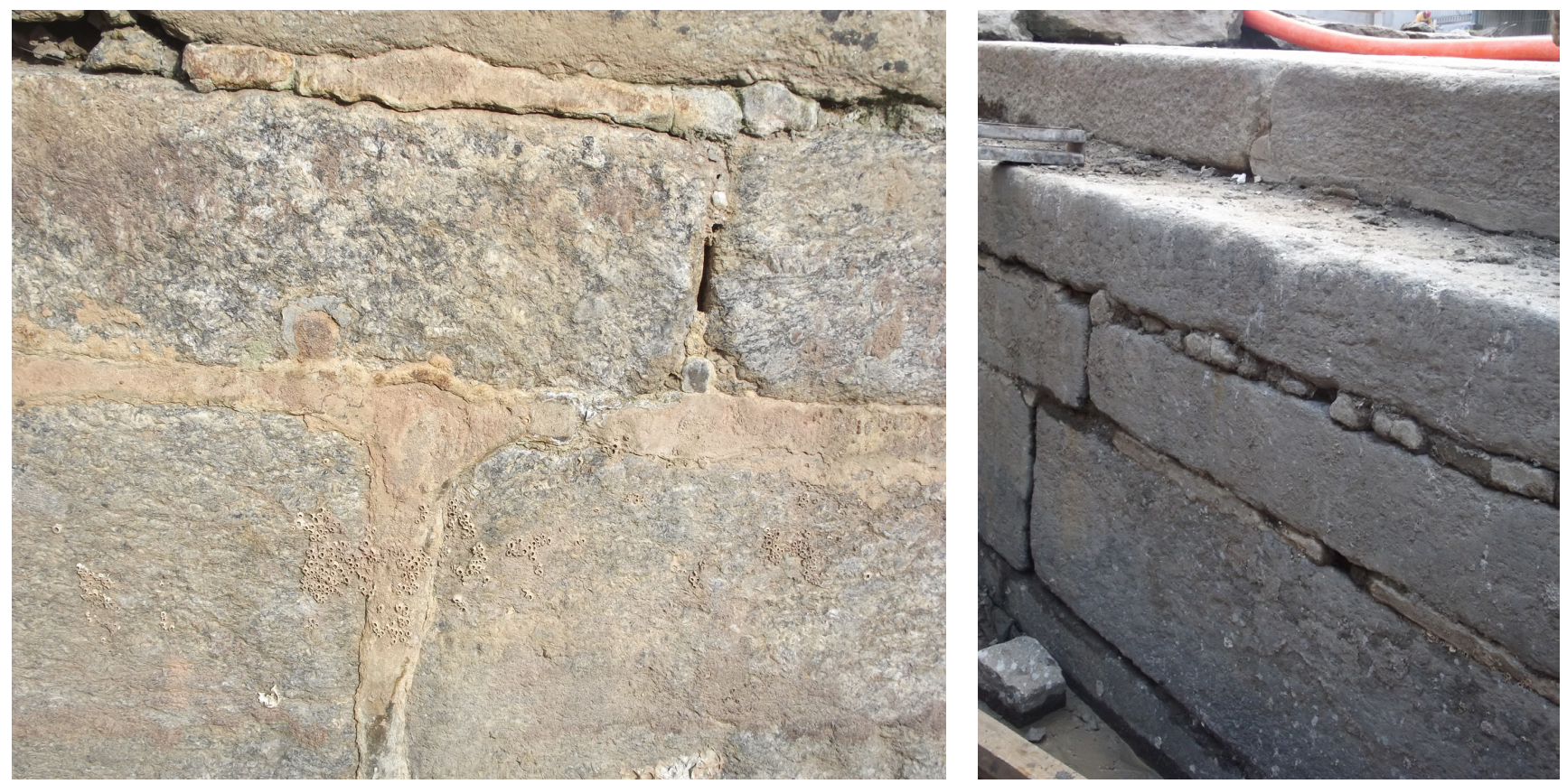

Figuras 85 e 86 - Preenchimento grosseiro das juntas do paredão lateral da rampa do cais, com argamassa ou pedras pequenas.

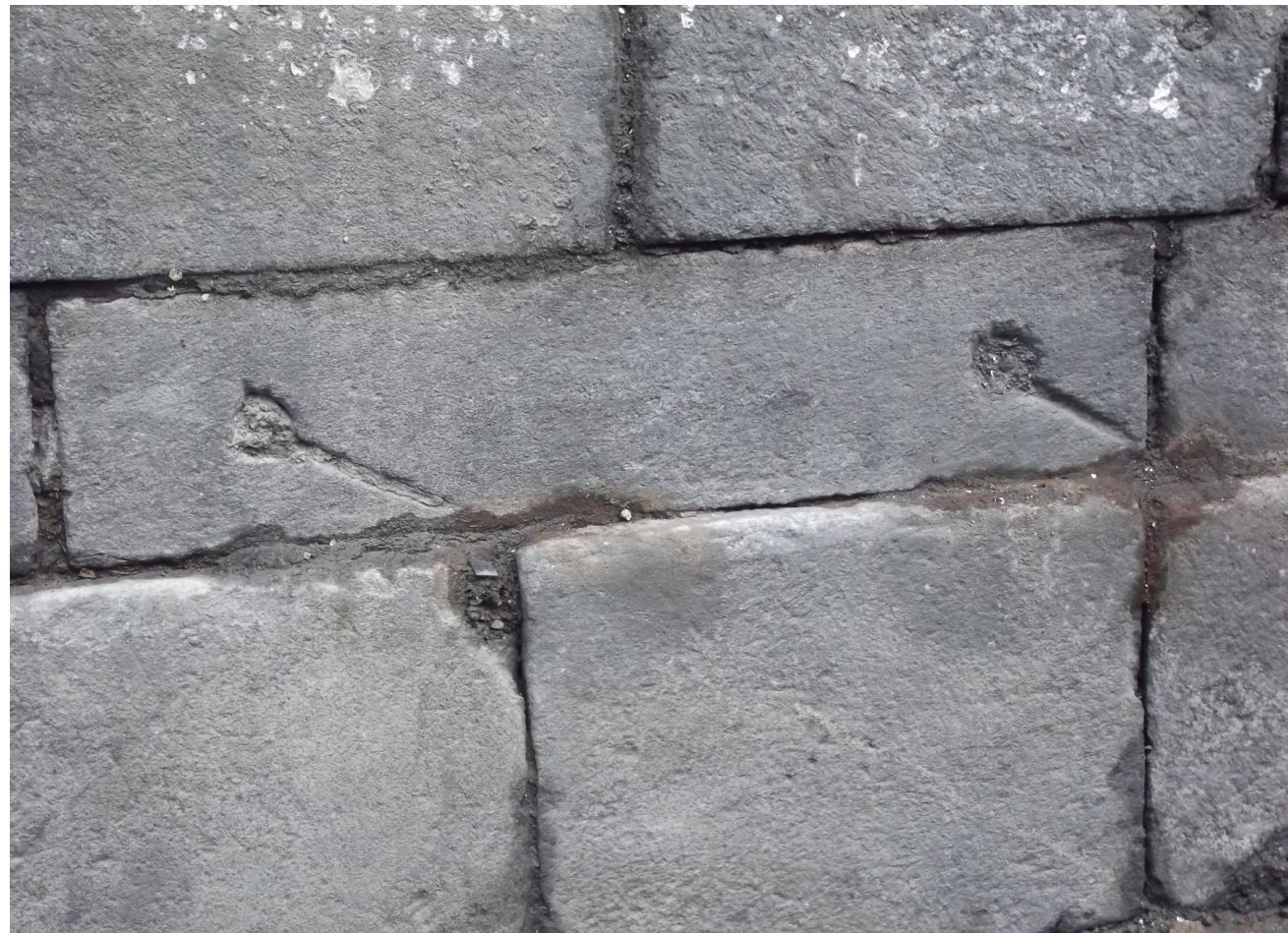

Figura 87 - Rebaixos produzidos por picoteamento e fricção que aparecem em uma das lajotas do paredão lateral da rampa do cais. Trata-se, provavelmente, de bloco reaproveitado de outro local, destinado possivelmente, em sua origem, a receber grampos para evitar o deslizamento de blocos rochosos dispostos horizontalmente, decorrente de impactos provocados pelo mar. 
A plataforma de lajotas do cais à direita da rampa de desembarque mediu em sua totalidade $14,0 \mathrm{~m}$ de extensão por 3,10 m de largura. Em superfície, ela apresenta blocos maiores e mais regulares na extremidade distal, e menores e menos regulares na proximal (com medidas muito variadas). Trata-se igualmente de uma edificação ciclópica, cujo sistema construtivo foi o mesmo da rampa, em alvenaria de pedras arrumadas, de dimensões variadas, porém em sua maioria grandes. Os dois degraus de acesso à praça, feitos de longos paralelepípedos retângulos (meios-fios medindo entre 1,25 e até 2,80 m de extensão $\times 0,20 \mathrm{~m}$ de largura) entremeados com outros de dimensões menores $(0,30$ e 0,85 $\mathrm{m} \times 0,20 \mathrm{~m})$, mediram $0,30 \mathrm{~m}$ de piso e $0,20 \mathrm{~m}$ de espelho para ambos (Figuras 88 a 90 ).

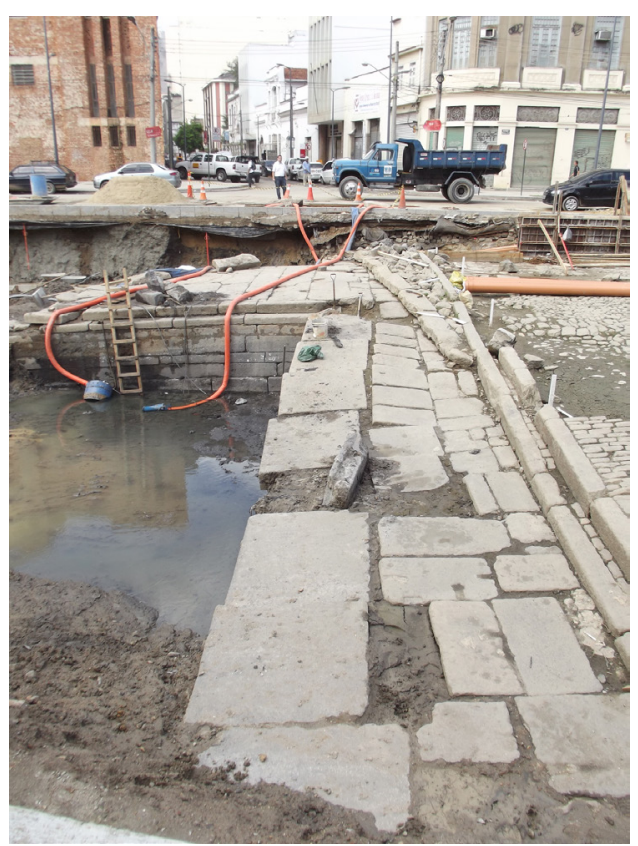

Figura 88 - Plataforma do cais com lajotas de pedra de diferentes dimensões, mas em sua maioria grandes.

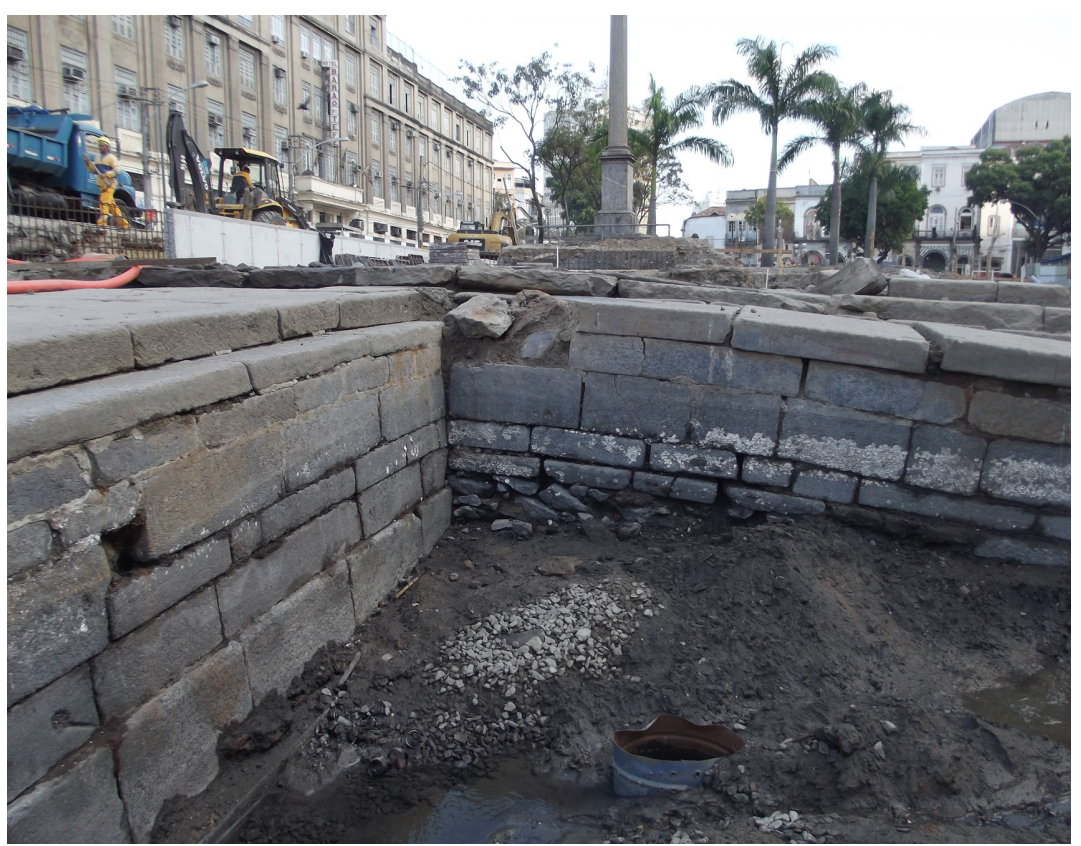

Figura 89 - Junção da parede ciclópica da rampa do cais com a parede à sua direita: ambas apresentam o mesmo sistema construtivo, atestando que a estrutura foi erguida de uma única vez.

A necessidade de canalizar as águas pluviais, que desciam de enxurrada pela Ladeira do Livramento por ocasião de chuvas fortes, fez com que fosse construída a canaleta de escoamento que atravessa todo o Valongo, desde as imediações da ladeira até o cais, tal como informado anteriormente na apresentação das Frentes 2 e 4 . Contudo, nada pode ser dito a esse respeito com referência ao Cais da Imperatriz, em virtude do seu calçamento ter sido em grande parte destruído. De todo modo, uma bica para desaguá-las no mar, em pedra lavrada, composta de duas metades unidas, foi encontrada nessa parede ciclópica, a 3,30 m da parede do Hospital dos Servidores do Estado e a 0,50 m abaixo da superfície das lajotas (Figuras 91 e 92). 


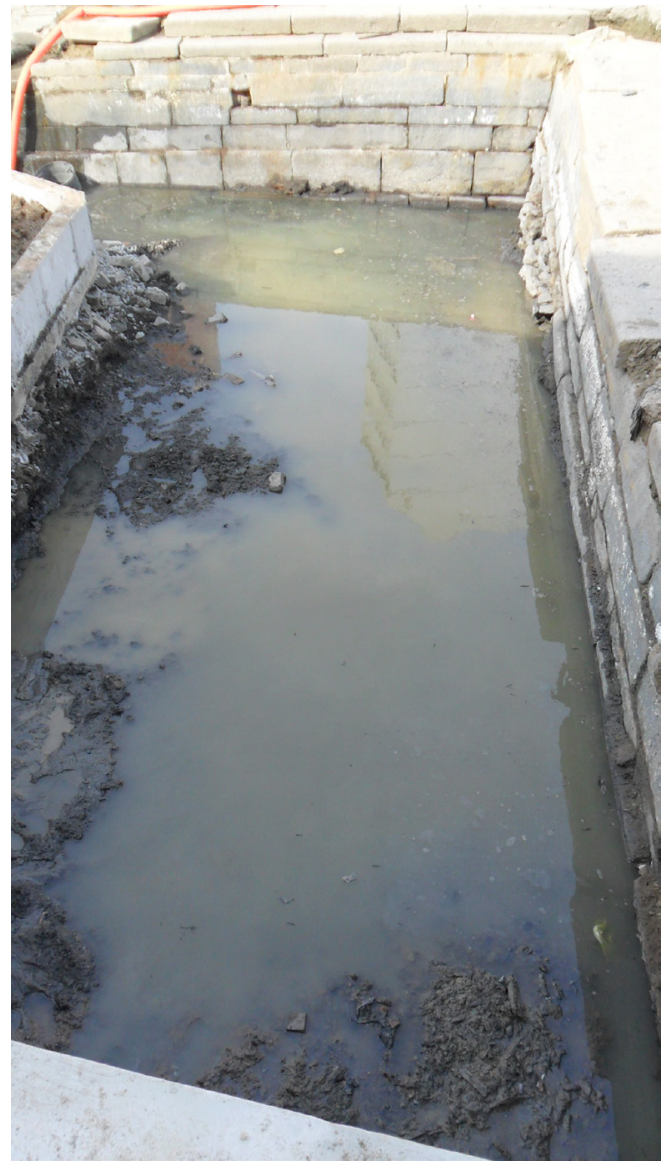

Figura 90 - Vista da área em frente ao cais, escavada até o nível alagado.

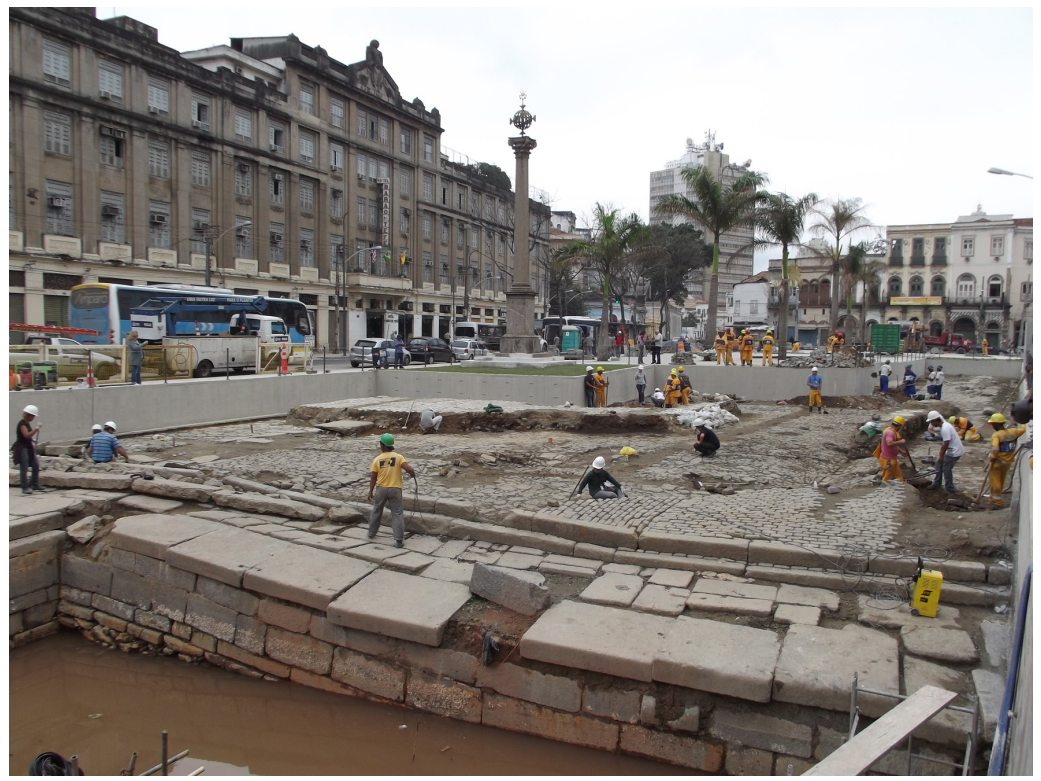

Figura 91 - Localização da bica na parede à direita da rampa do cais, desaguando no mar as águas provenientes de enxurradas da Ladeira do Livramento.

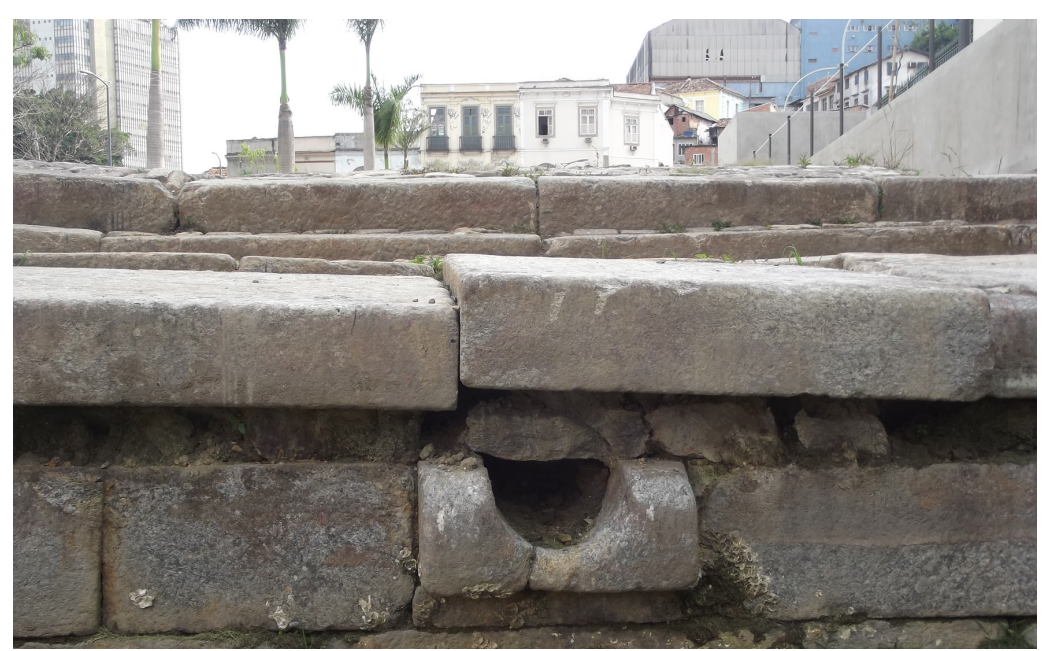

Figura 92 - Detalhe da bica em pedra lavrada, composta por duas pedras unidas. Note-se o mal sucedido preenchimento com pedras por baixo de uma das lajotas da plataforma, tentando mantê-la no nível original.

Trata-se de peça formal e tecnologicamente muito semelhante à encontrada na Frente 1, feita para o sistema de drenagem da City Improvements na década de 1860 ou 1870, também composta por duas metades unidas. Essa evidência, somada às informações obtidas no registro documental, permitem levantar a hipótese de que parte da última ou das duas últimas carreiras de lajotas de pedra foram retiradas para a colocação da bica e reassentadas novamente. 
Aqui cabe assinalar que, em momento também aparentemente tardio, foi colocado sob a última carreira um enchimento de pedras para erguê-las, uma tentativa de retirá-las do equilíbrio instável em que se encontravam, deslocadas e inclinadas em direção ao mar.

Essa parede apresenta sérias avarias. Ocorreu um dano expressivo na sua base, que foi reparado colocando-se pedras de mão como preenchimento, em substituição aos blocos que desapareceram (Figuras 93 a 98). $\bigcirc$ registro documental à época menciona estragos frequentes feitos por embarcações que se chocavam de encontro ao cais, além dos impactos do mar, descritos como violentos, ambas causas possíveis para uma avaria dessa magnitude. Essa tentativa de manutenção foi com certeza tardia, iá que uma das pedras utilizadas nesse reparo apresenta marca de dinamite, de tal forma que ela é, necessariamente, posterior à década de 1870.

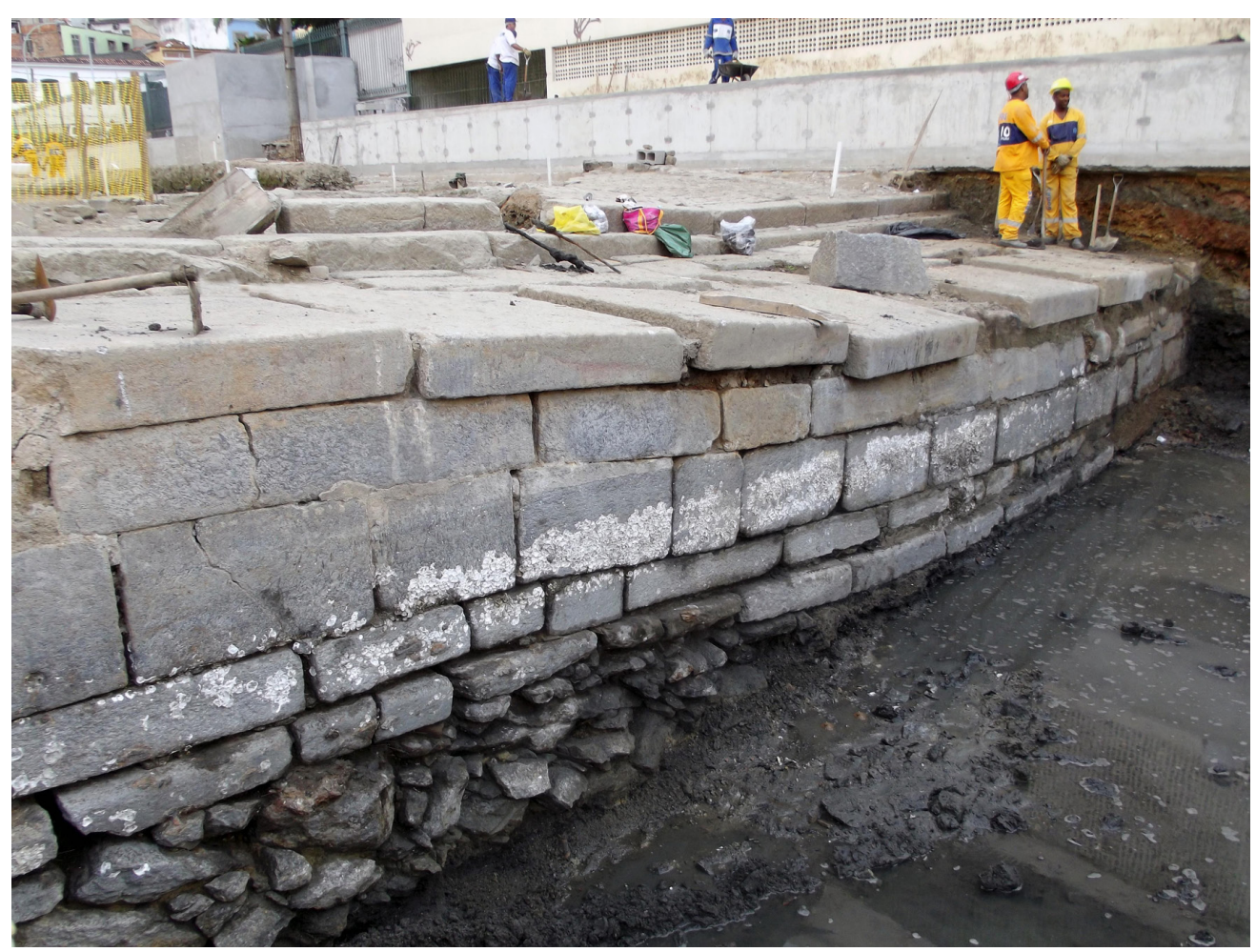

Figura 93 - As sérias avarias ocorridas na parede à direita da rampa de desembarque: afundamento da estrutura no trecho correspondente ao deságue das águas provenientes do Morro do Livramento, que solaparam suas bases; rombo na porção inferior da parede, compensado com o preenchimento com pedras de mão; e grandes rachaduras em três lajotas, expondo sua situação de absoluta precariedade. Uma sequência de carapaças de ostreídeos aderidas às pedras e alinhadas ao longo dessa parede atesta o nível médio do mar à época. Esse paredão apresentou 2,10 m de altura, mas apenas 1,30 m no trecho em que a estrutura afundou.

Annals of Museu Paulista. v. 24. n.1. Jan.-Abr. 2016. 


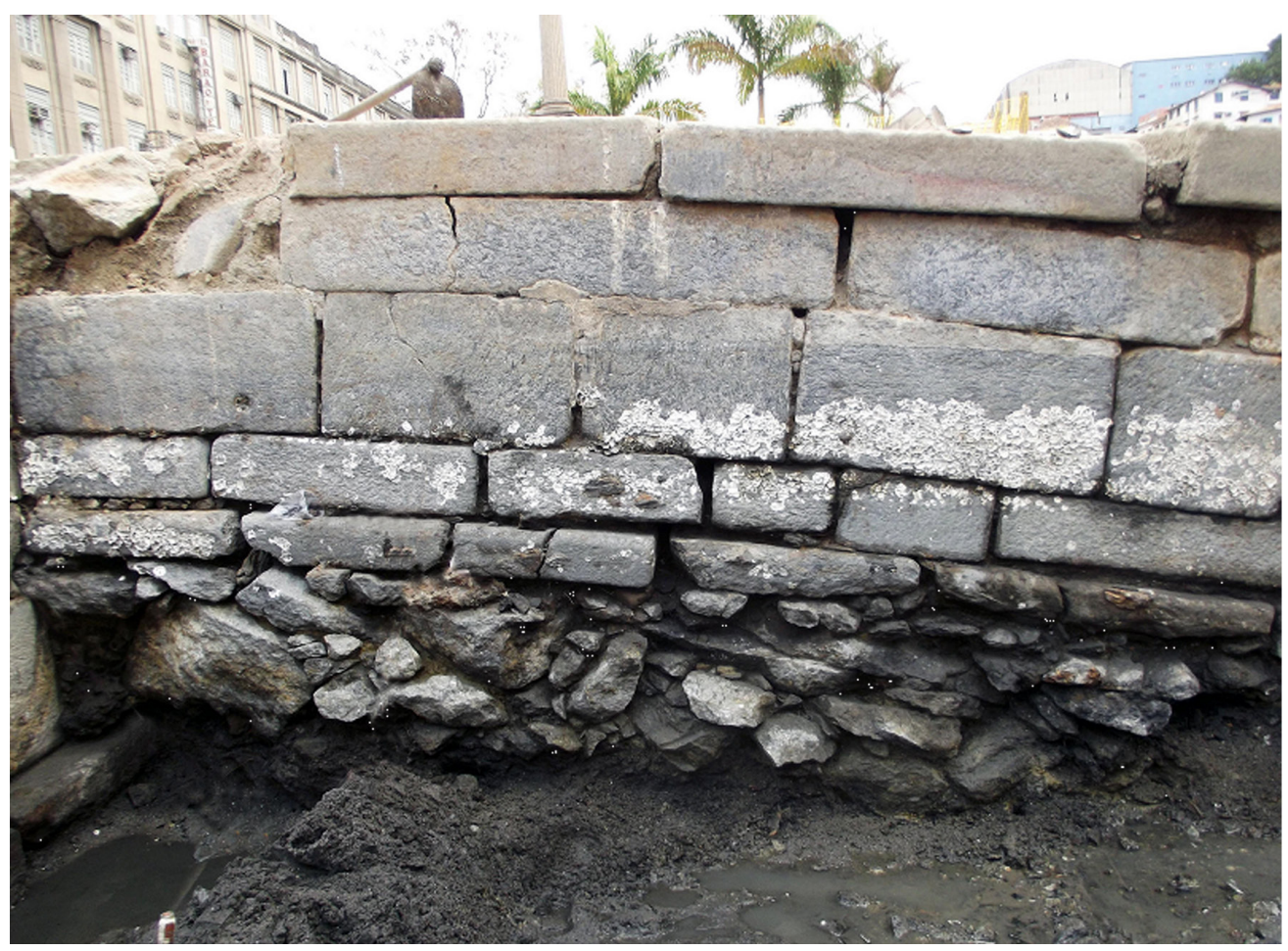

Figura 94 - Preenchimento da base da estrutura com pedras de mão para evitar seu colapso.

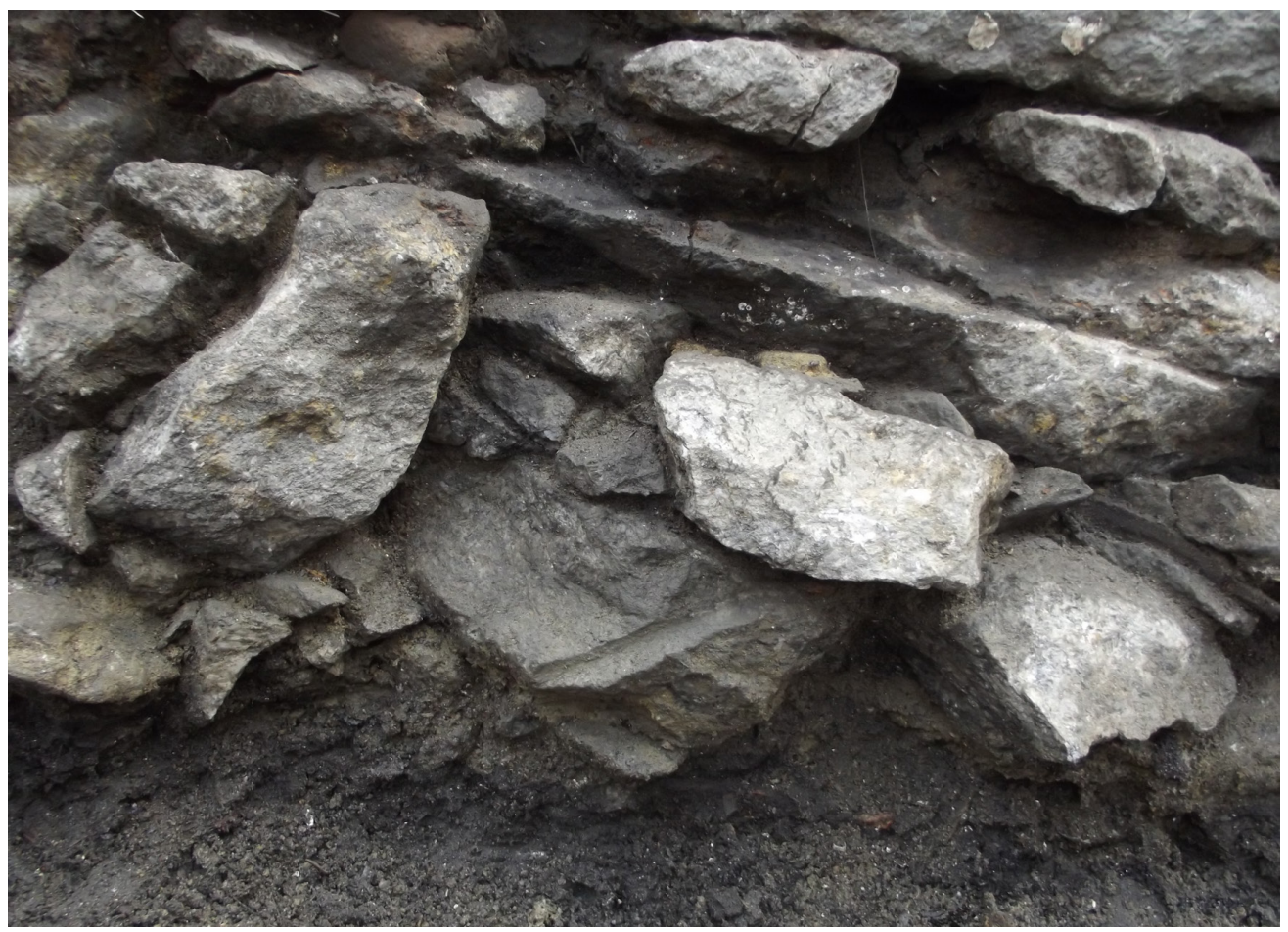

Figura 95 - Marca de dinamite em uma das pedras na base da estrutura, atestando que se trata de reparo posterior à década de 1870 . 
Provavelmente como desdobramento dessa ocorrência, três blocos exibem grandes rachaduras, que coincidem com essa base danificada, sinalizando que a estrutura se encontrava sob forte tensão, emitindo sinais de colapso iminente.
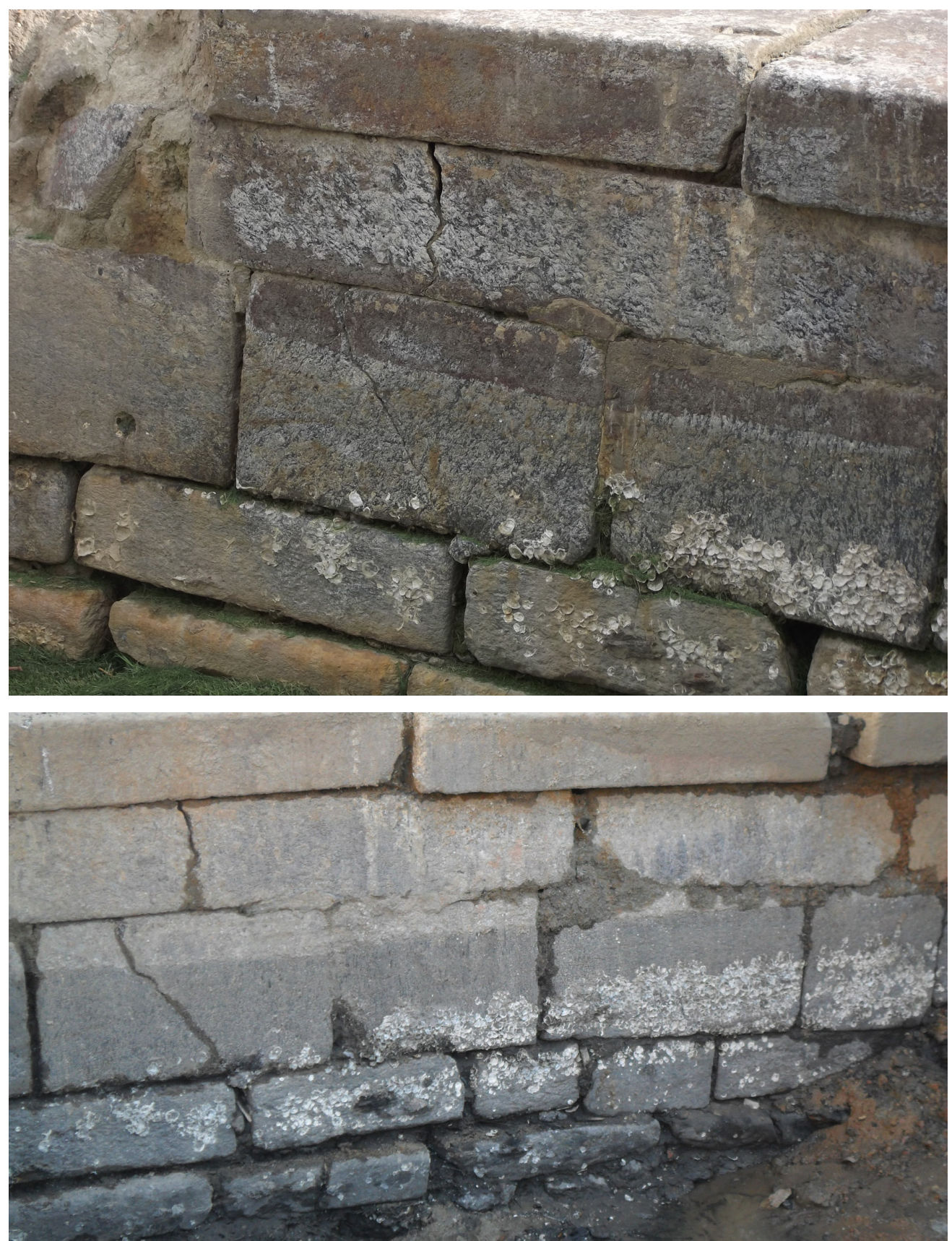

Figuras 96 e 97 - Grandes rachaduras nos blocos rochosos expõem a tensão da estrutura à época, ameaçada de colapso.

Annals of Museu Paulista. v. 24. n.1. Jan.-Abr. 2016. 
Pouco adiante desse reparo, o terreno parece ter cedido, e, junto com ele, outro trecho dessa parede ciclópica afundou consideravelmente (Figura 98); ao que parece, como resultado de infiltrações no solo de grandes volumes de águas pluviais que, provenientes do Morro do Livramento, aí encontravam seu caminho natural, minando o terreno de tal forma que acabou solapando parcialmente a estrutura.

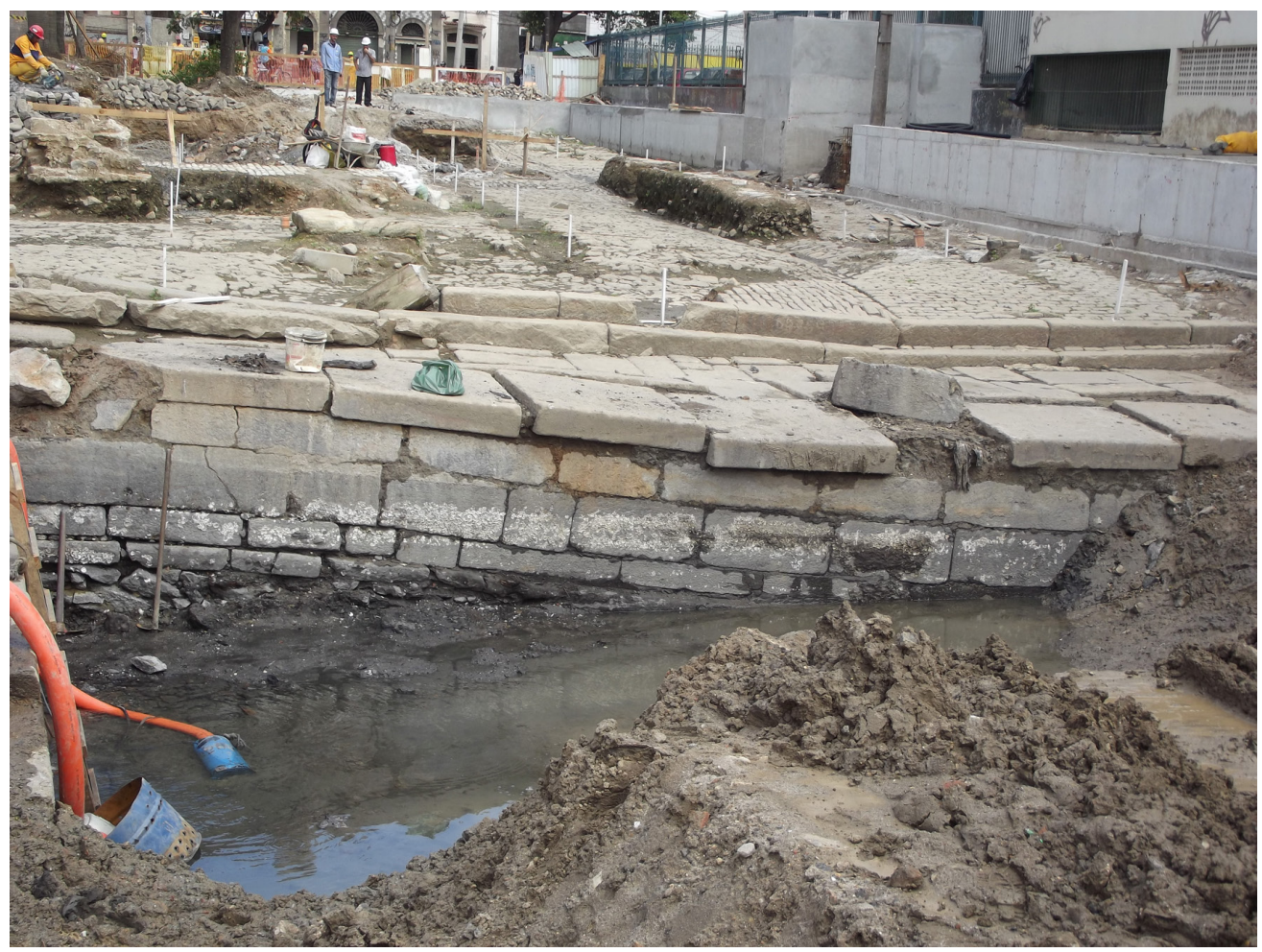

Figura 98 - $\bigcirc$ estado deplorável da estrutura do cais, já sem condições de recuperação.

O registro documental faz referência, em 1891, à necessidade de se promover reparos na "parte abatida" do cais, no que pode ser uma referência tanto ao rombo na sua base quanto ao afundamento de parte da estrutura. Mas suas condições já eram a essa altura de tal forma precárias, que dificilmente seria recuperável.

Essa foi a última frente de trabalho escavada na área do Cais do Valongo e do Cais da Imperatriz, encerrando a etapa das escavações no sítio em junho de 2012. Como resultado desse trabalho, os remanescentes dos dois cais ficaram expostos, por decisão da Prefeitura do Rio de Janeiro, exceto no trecho correspondente à pista de rolamento esquerda da avenida Barão de Tefé, por onde corre, em subsolo, a galeria de águas pluviais. Já a da direita foi eliminada, de modo a deixar à mostra as estruturas encontradas. A Praça Jornal do Commercio foi reurbanizada, assim como a área em frente ao cais, onde foram feitas escadas e rampas de acesso, bem como um ponto de observação para os visitantes. 
Interpretação preliminar dos achados

As escavações arqueológicas que trouxeram à tona remanescentes do cais construído na região do Valongo, em 181 1, pelo Intendente Paulo Fernandes Viana, expuseram um calçamento que, embora composto por pedras irregulares e grosseiramente talhadas, foi feito com esmero, bem arrematado nas suas bordas e com um primoroso sistema de drenagem (Figuras 99 a 101 ).
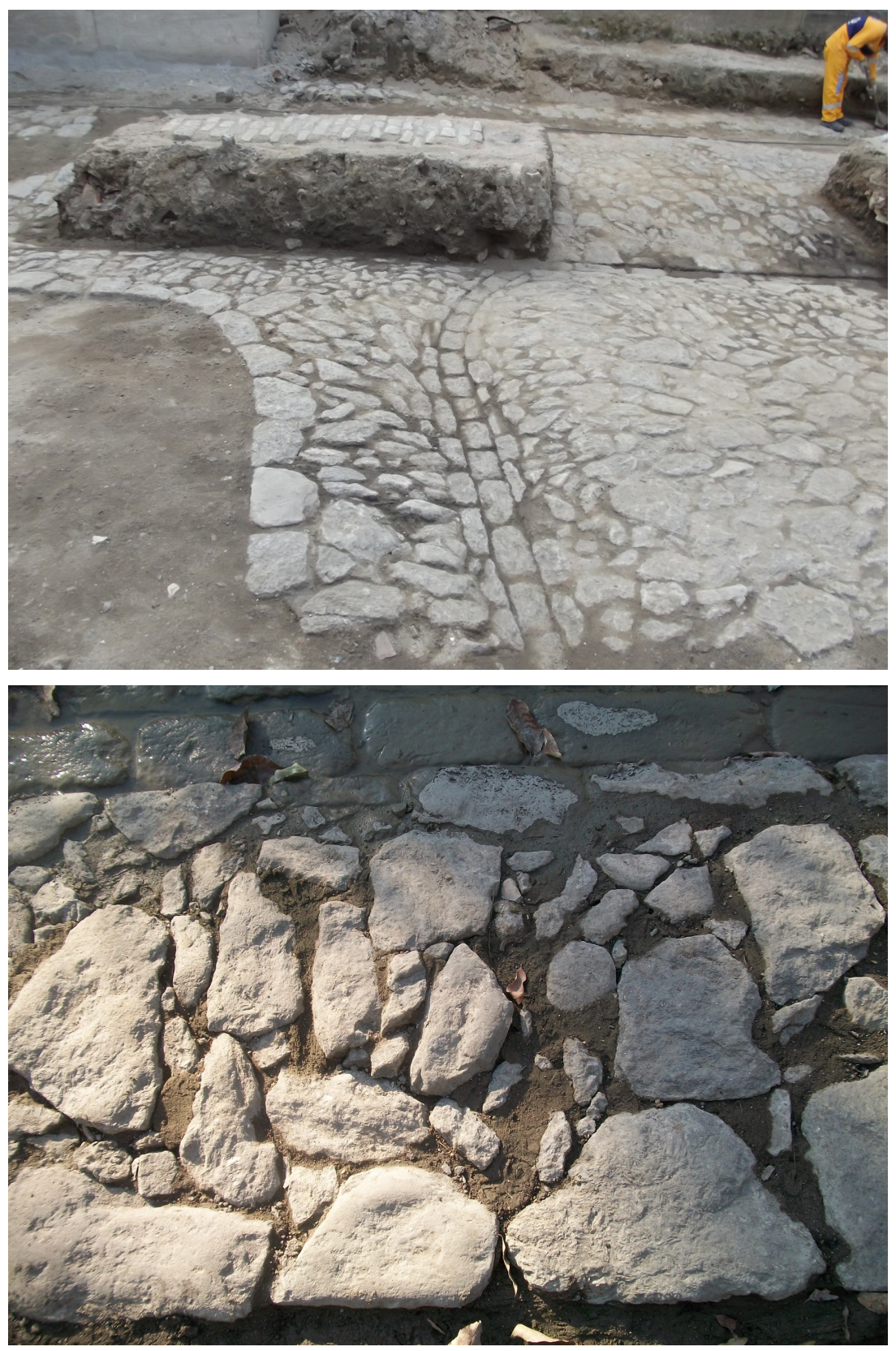

Figuras 99 e 100 - A execução esmerada do calçamento do Cais do Valongo. 


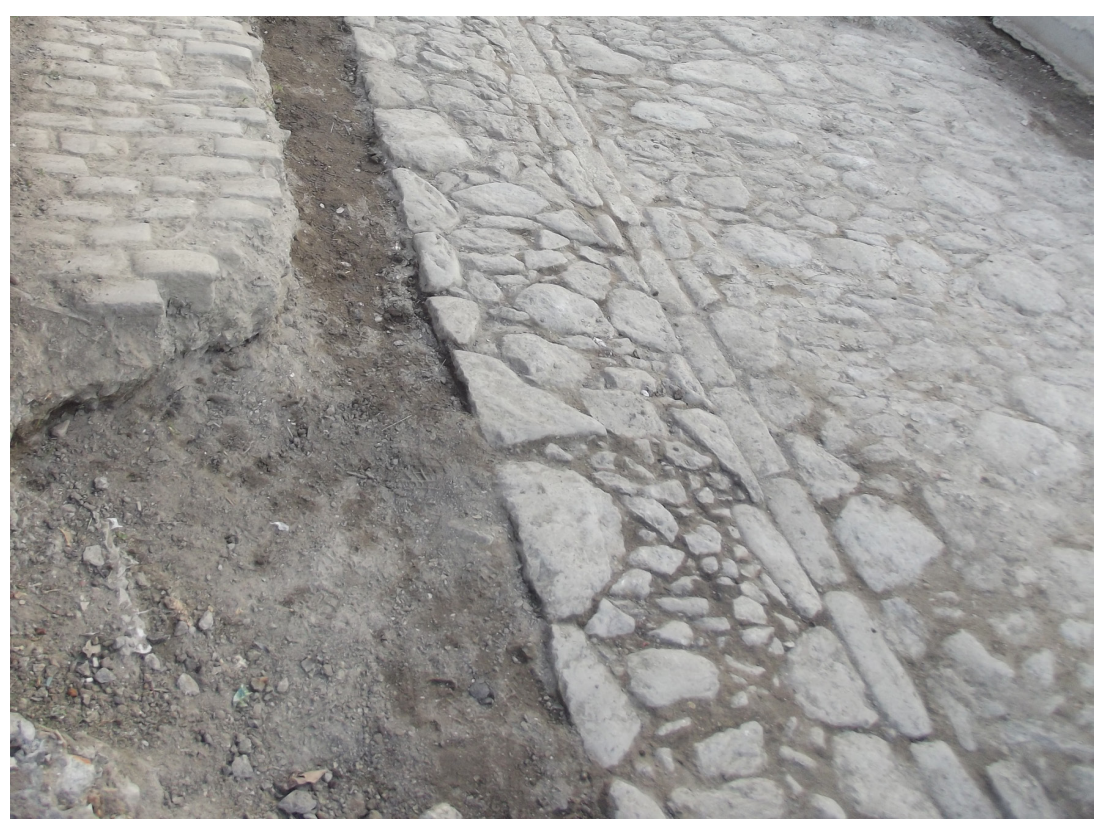

Figura 101 - A execução esmerada do calçamento do Cais do Valongo.

À sua direita, corria a vala de escoamento natural das águas oriundas dos morros e do interior, que desciam até o mar. À sua esquerda, foi feita uma canaleta principal, no sentido longitudinal, que drenava as águas que desciam de enxurrada pela Ladeira do Livramento, também até o mar; e pelo menos uma valeta secundária, que, no sentido transversal, desaguava na canaleta principal. Um excelente caimento voltado para ambas as direções assegurava o escoamento das águas pluviais, livrando a área de alagamentos em um local bastante suscetível a esse tipo de problema, agravado pela subida incessante das águas na maré alta, que o inundavam periodicamente.

Embora o trecho da pequena escada à qual se referem os documentos deixados pelo Intendente Paulo Viana não tenha sido escavado abaixo do nível das lajotas do Cais da Imperatriz, foi possível constatar a existência de pelo menos dois de seus degraus por meio de uma observação oportunística, na circunstância do deslocamento e emborco de uma das pedras que the foram superpostas, ocorridos certamente antes do aterro do início do século XX. Essa pequena escada conduzia a uma rampa central, alinhada com um caminho de lajotas retangulares que foi encontrado em grande parte destruído, dele tendo restado apenas um segmento intacto, algumas pedras isoladas e trechos da borda que the servia de arremate, em ambos os lados. Pelo fato de o segmento mais expressivo dos paralelos do Cais da Imperatriz ter sido preservado justamente nesse trajeto, ocultando-o em parte, e pela coluna dedicada à celebração do desembarque da Imperatriz Teresa Cristina the ter sido sobreposta, não foi possível saber sua extensão real; mas o que dele restou visível permite supor uma extensão de pelo menos $26 \mathrm{~m}$, desde o cais até a coluna (Figura 102). 


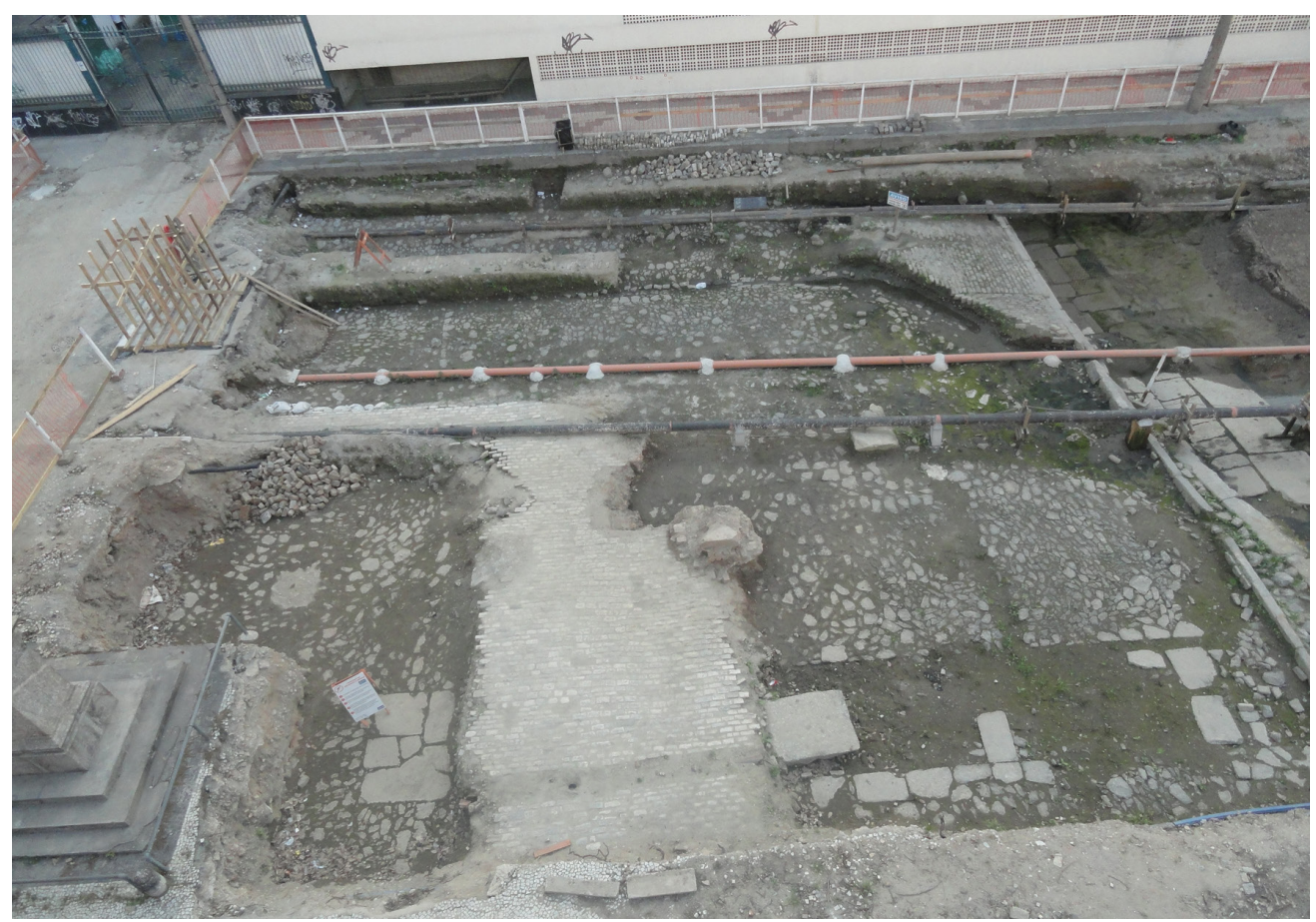

Figura 102 - Vista do calçamento do Cais do Valongo nas Frentes 2 e 3, do caminho de lajotas de pedra bastante desfalcado de seus componentes originais, e das "ilhas" do Cais da Imperatriz. Vê-se ainda algumas das redes subterrâneas que atravessaram ambos os cais, danificando-os, e algumas cicatrizes de outras tubulações já retiradas.

Pouco adiante desse caminho, foram encontrados remanescentes do arremate do calçamento do Valongo, que sinalizam seu limite nesse trecho central. À sua esquerda e à sua direita, uma curva delimita claramente o interior da área correspondente à praça atual, onde não foram encontrados vestígios das suas pedras irregulares. Em seu lugar foi detectado um piso de terra batida, muito compactado, observado nas sondagens feitas na praça, a cerca de 1,20 m de profundidade média. Na única planta do Valongo até agora encontrada, datada de 1837, está assinalada a existência de barracões nesse trecho, provavelmente de madeira, e esse deve ter sido seu piso original. $O$ arremate das pedras do Valongo emoldurando essa área de terra batida sustentam fortemente a possibilidade de esses barracões serem da época anterior à interdição do tráfico, os quais teriam perdurado até o ano em que a planta foi feita, ou mesmo até pouco mais tarde, com funções provavelmente relacionadas às intensas atividades comerciais ali desenvolvidas.

A única evidência direta de uma construção feita no Cais do Valongo foi o alinhamento de quatro esteios de madeira, três in situ e um deslocado, próximo ao limite com o Hospital dos Servidores do Estado e com a antiga rua da Praia do Valongo, hoje rua Sacadura Cabral. Não foi possível saber se essa construção, precária e efêmera, provavelmente um abrigo provisório com 
cobertura de palha ou de telhas para mercadorias, pessoas ou mesmo animais, se estendia em direção à área do atual HSE ou se à, hoje, Praça Jornal do Commercio, tendo em vista que não foram encontradas as contrapartes desses esteios. Eles foram recuperados fincados na terra, no nível do Cais do Valongo, em trecho onde suas pedras estavam ausentes, embora sondagens realizadas em direção ao hospital tenham deixado suficientemente claro que o calçamento se estendeu até pelo menos o espaço ocupado pelo seu pátio na atualidade. Assim, as limitações desse achado não permitem senão especulações vagas sobre suas natureza e função.

Ao longo da galeria de águas pluviais da avenida Barão de Tefé que corresponde à vala de escoamento natural, tampouco foram encontrados remanescentes do calçamento do Cais do Valongo. Isto é perfeitamente compreensível, se for considerado que essa era uma área, ao que as circunstâncias permitem crer, em geral alagada. Na planta de 1837, aí figura um taboado que deve ter sido colocado sobre essa vala para possibilitar o trânsito de pessoas, o que por certo facilitava o despejo, nela, de toda sorte de dejetos. Quatro anos depois, em documento datado de 1841, a Câmara solicitou orçamento para "tapar a vala imunda que existe junto do denominado Cais do Valongo, dispondo convenientemente o lugar para o fácil escoamento das águas", o que confirma seu entulhamento decorrente das práticas de descarte no local. Isso foi comprovado também pela pesquisa arqueológica, que recuperou nessa área o maior número de vestígios de toda a área do cais.

Remanescentes do calçamento e do arremate do Valongo foram encontrados somente mais próximos à praça, a 3,60 m de distância do meio-fio que a delimita hoje em dia. As escavações expuseram um pequeno segmento com uma borda em pedras retangulares, caracterizando o limite do Valongo desse lado, e atestando que, de fato, o calçamento do cais não se estendeu ao longo da área da drenagem natural das águas pluviais, estando seus contornos nas proximidades imediatas da praça atual.

Do lado oposto, junto ao HSE, tampouco foi possível detectar seus limites, já que ele se estendia em direção ao pátio do hospital, hoje ocupado por um estacionamento, o que inviabilizou intervenções no local. Mesmo assim, a canaleta principal de escoamento de águas pluviais pode ser tentativamente utilizada como um possível elemento para se cogitar a área ocupada pelo cais deste outro lado, se atribuirmos a ela, originalmente, uma centralidade neste espaço. Hoje, sua condição é de total assimetria na área exposta pelas escavações, o que decerto não corresponde ao que era à época, de tal forma que uma projeção, de caráter meramente especulativo, pode ser feita no sentido de se tentar estabelecer a área original do Cais do Valongo junto ao HSE.

Tanto na pista da esquerda quando na antiga pista da direita da avenida Barão de Tefé, nas proximidades da rua Sacadura Cabral, o calçamento do Cais do Valongo terminou abruptamente. À sua direita, em decorrência de interferências no subsolo que o removeram, e, à esquerda, suas pedras apareceram 
desmanteladas, sendo impossivel afirmar até onde ele se estendeu precisamente. Pode ser dito apenas que ele foi recuperado até o Trecho 1 1, sendo provável que se prolongasse até bem próximo à rua da Praia do Valongo, hoje rua Sacadura Cabral.

Ao que indica a reclamação feita por moradores da região em 1829, àquela altura o cais não era exclusivo do tráfico negreiro. Queixando-se da movimentação frenética naquele local, eles alegavam que por ali embarcavam e desembarcavam milhares de pessoas, além de variados produtos e gêneros, o que tornava o lugar intransitável. Com a Lei de 07 de novembro de 1831, que declarava livres todos os africanos que entrassem no país a partir daquela data, houve uma queda brusca no comércio transatlântico. $\bigcirc$ Valongo, como local de desembarque de escravos, decerto foi desativado, ao menos temporariamente, como demostram os números quase zerados de entradas de africanos no país ${ }^{72}$. As demais atividades, no entanto, foram mantidas e o cais continuou sendo utilizado intensamente. Contudo, uma vez passado o impacto inicial da lei, novas levas de africanos continuaram a chegar, com o restabelecimento e o recrudescimento do tráfico agora clandestino, sob o disfarce de comércio interprovincial. Não há evidências de que eles tenham passado escamoteados pelo Valongo. Mas se isso ocorreu, essa movimentação só viria a cessar de fato nos primeiros anos da década de 1840, com o novo uso dado ao local.

Em decorrência do casamento de D. Pedro II com a princesa das Duas Sicílias, Teresa Cristina Maria de Bourbon, realizado por procuração em Nápoles, em 1843, era preciso preparar a sua recepção na chegada ao Rio de Janeiro. Para o desembarque da Imperatriz do Brasil, foi escolhido precisamente o degradado Cais do Valongo, que passou por ampla reforma. $\bigcirc$ projeto do novo cais e da praça, esta última de caráter monumental, foi concebido com um requinte condizente com a circunstância, tendo sido ambos renominados respectivamente como Cais da Imperatriz e Praça Municipal. A rua do Valongo passou a se chamar rua da Imperatriz, configurando uma estratégia para apagar em definitivo da região um nome fortemente associado a sua tenebrosa história.

Da única representação do Cais da Imperatriz existente, feita por Pustkow (ver Figura 9), pouco foi encontrado além da rampa, dos degraus de acesso e da plataforma, relativamente preservados. Os materiais aí utilizados aparecem descritos no registro documental, que menciona a compra e o transporte de pedras lavradas para a reforma empreendida em 1843. Do gradil não restaram vestígios, eliminados provavelmente em reformas posteriores. Do mesmo modo, do pavilhão hexagonal de teto abobadado nada restou, sequer fundações, sugerindo tratar-se de exemplar de arquitetura efêmera, destinada a cumprir uma função provisória e erigida com materiais facilmente removíveis. De fato, seu desmanche parece ter ocorrido logo em seguida, a julgar pelo documento encaminhado pela Câmara Municipal ao fiscal de Santa Rita, em dezembro de 1843, no qual se recomendava a demolição "do torreão que existe na dita praça afim de se poder calçar aquele lugar"73.
72. Ver David Eltis; Martin Halbert (2008).

73. Arquivo Geral da Cidade do Rio de Janeiro. Códice 36.2.4, fl. 260 . 
Sobreviveram apenas algumas ilhas esparsas do calçamento em paralelos, severamente danificado ao longo do século XX pela passagem, em diferentes momentos, de redes subterrâneas de água, esgoto, gás, luz, drenagem de águas pluviais, telefonia e fibra ótica. Mais profundo, o calçamento do Cais do Valongo foi menos afetado, o que possibilitou sua preservação em melhores condições, embora tenha sido também atingido em certos pontos. Alguns trechos recuperados desse calçamento de paralelos permitem supor que ele foi feito em padrões geométricos, ora retilíneos, ora curvilíneos, mas sua descontinuidade não permitiu uma recomposição mínima de sua feição original (Figuras 103 a 105).
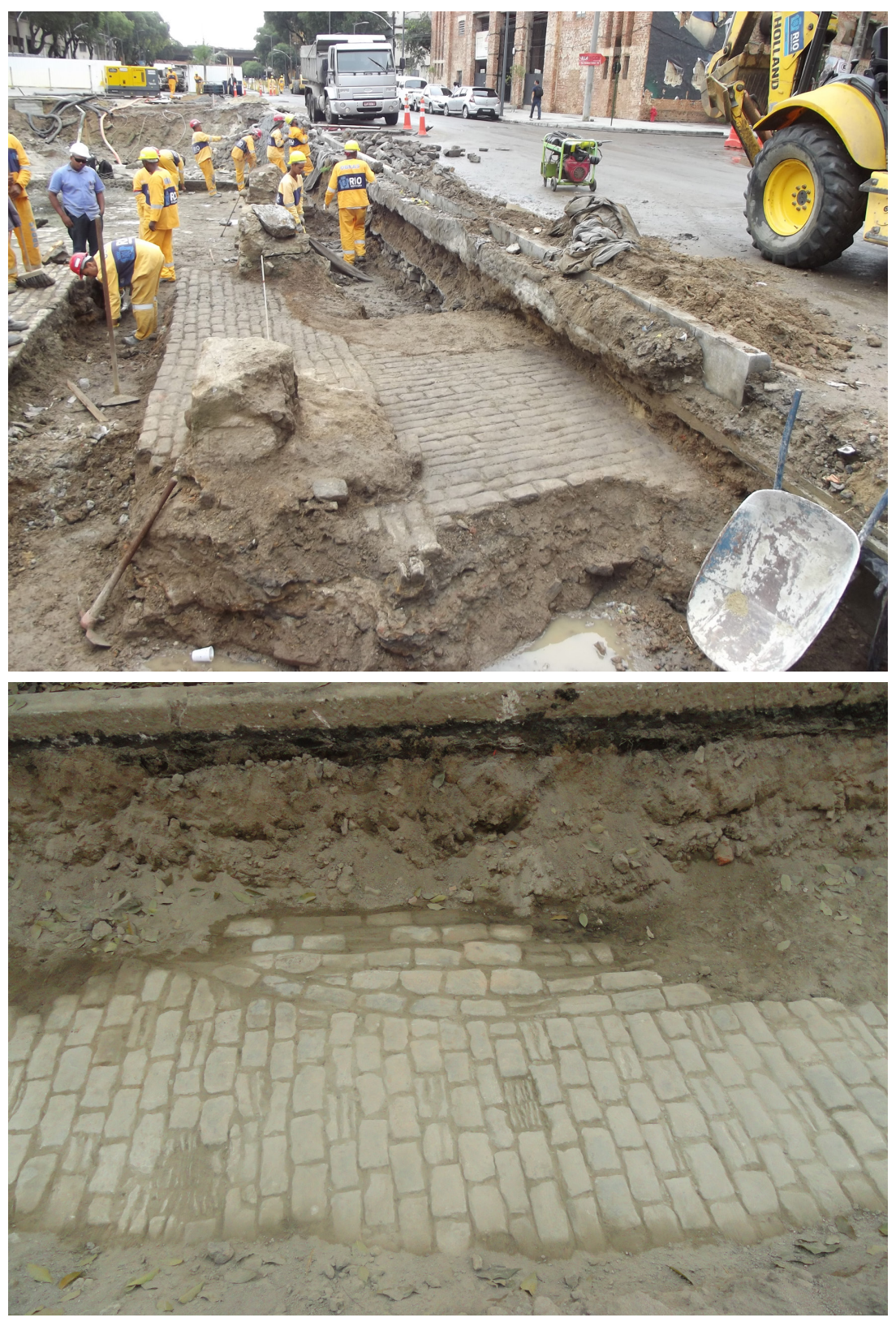


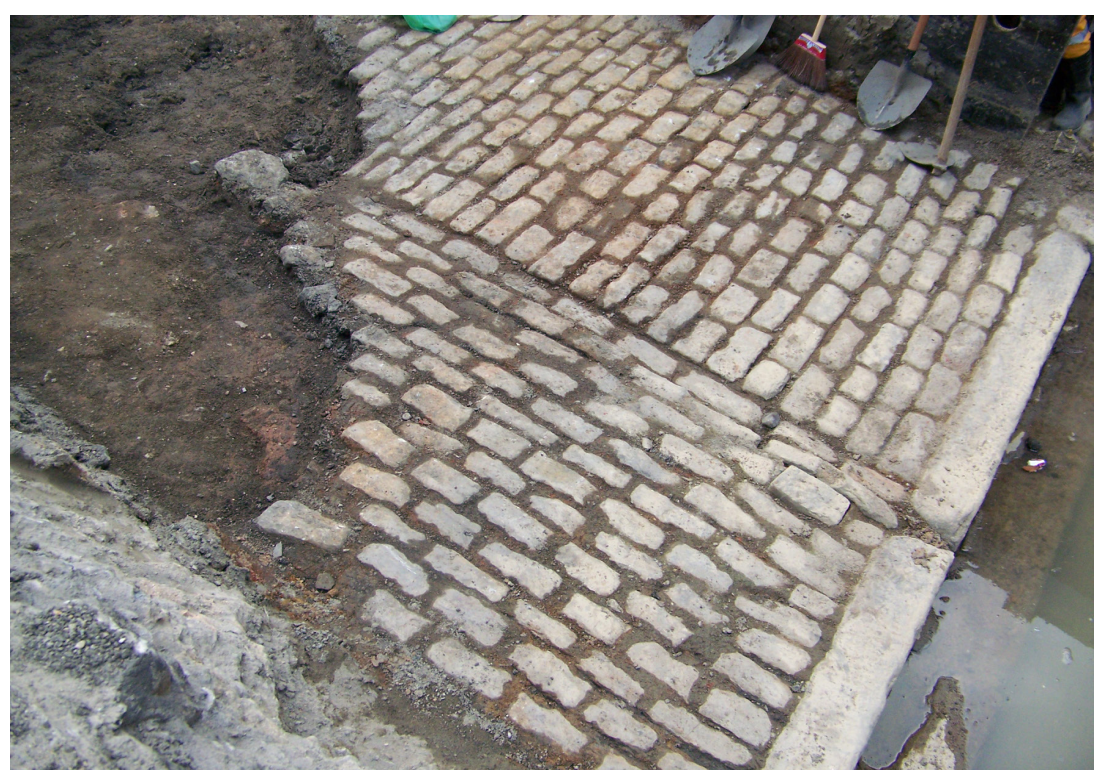

Figuras 103 a 105 - Diferentes trechos do calçamento do Cais da Imperatriz, em composições geométricas.

De todo modo, a grande reforma no cais e na praça do Valongo, feita para a chegada da imperatriz, parece ter ficado inconclusa. Há menção a um lajeado, que, segundo sugestões, deveria ser substituído por um calçamento, possivelmente o de paralelos, o qual teria sido feito após o evento. Da mesma forma, o embelezamento da praça com as quatro estátuas de divindades grecoromanas foi posterior. $\bigcirc$ projeto de um chafariz monumental para comemorar a chegada da princesa, de autoria comprovada de Grandjean de Montigny, nunca chegou a ser executado, tendo sido encontrada nas escavações apenas a base de um outro chafariz, feito para atender à população e às embarcações, por volta de 1842-1843. Depois do evento, o Cais da Imperatriz e a Praça Municipal parecem ter mantido sua qualidade apenas por uns poucos anos. Com o passar do tempo, ambos parecem ter sofrido um processo progressivo de degradação, aparentemente agudizado na década de 1870, quando figuram no registro documental como "em péssimo estado" de conservação.

Talvez por essa razão, foi precisamente nessa década que foram feitos diferentes investimentos no local, existindo múltiplas evidências que permitem supor a revitalização e a requalificação daquele espaço. Foi implantado o sistema de drenagem concebido por Edward Gotto e executado pela City Improvements, exatamente na área da antiga e fétida vala de escoamento natural de águas pluviais que corria ao lado do cais e da praça do Valongo. Foi feito um acabamento similar ao do restante do atracadouro, em pedras lavradas, de modo a integrar o terminal da drenagem ao cais existente. Do lado oposto, foi colocada uma bica de pedra lavrada, morfológica e tecnologicamente idêntica à que foi posta no terminal para o deságue das águas pluviais oriundas da íngreme ladeira do Livramento, no que parece ter sido um cuidado com a simetria do conjunto (Figuras 106 e 107).

Annals of Museu Paulista. v. 24. n.1. Jan.-Abr. 2016. 


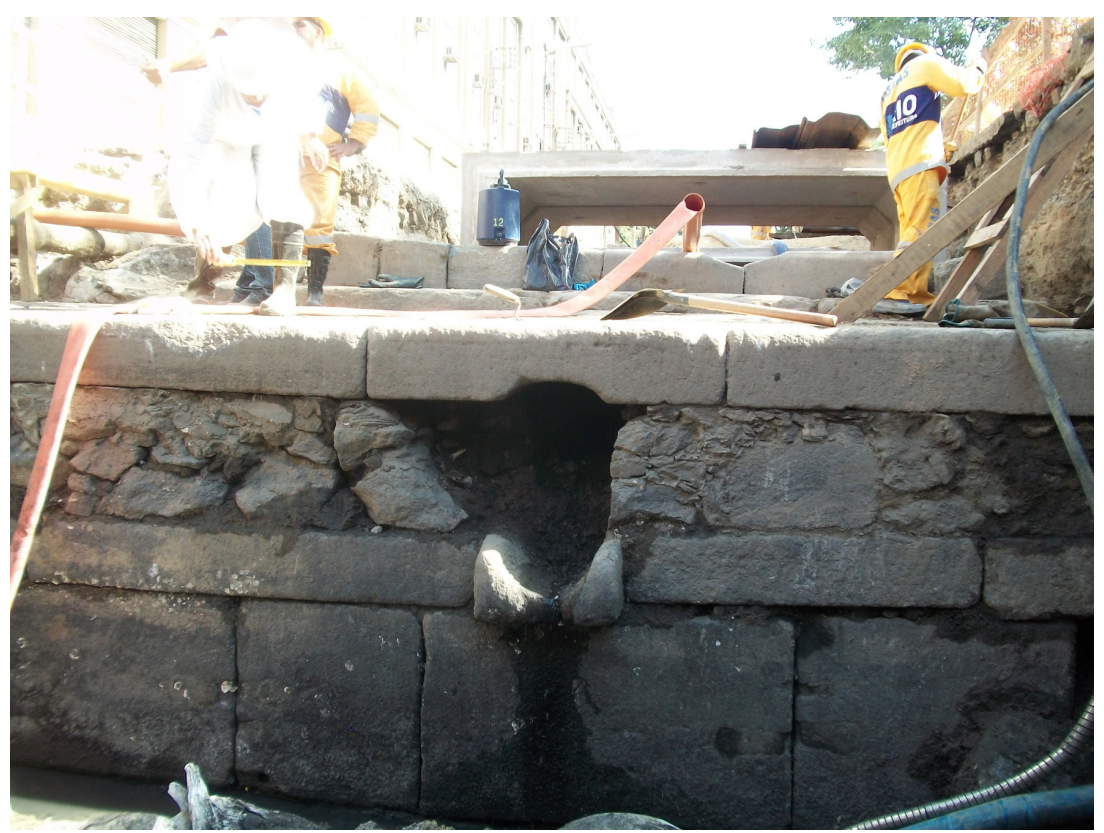

Figura 106 - Bica terminal do sistema de drenagem de águas pluviais da City Improvements.

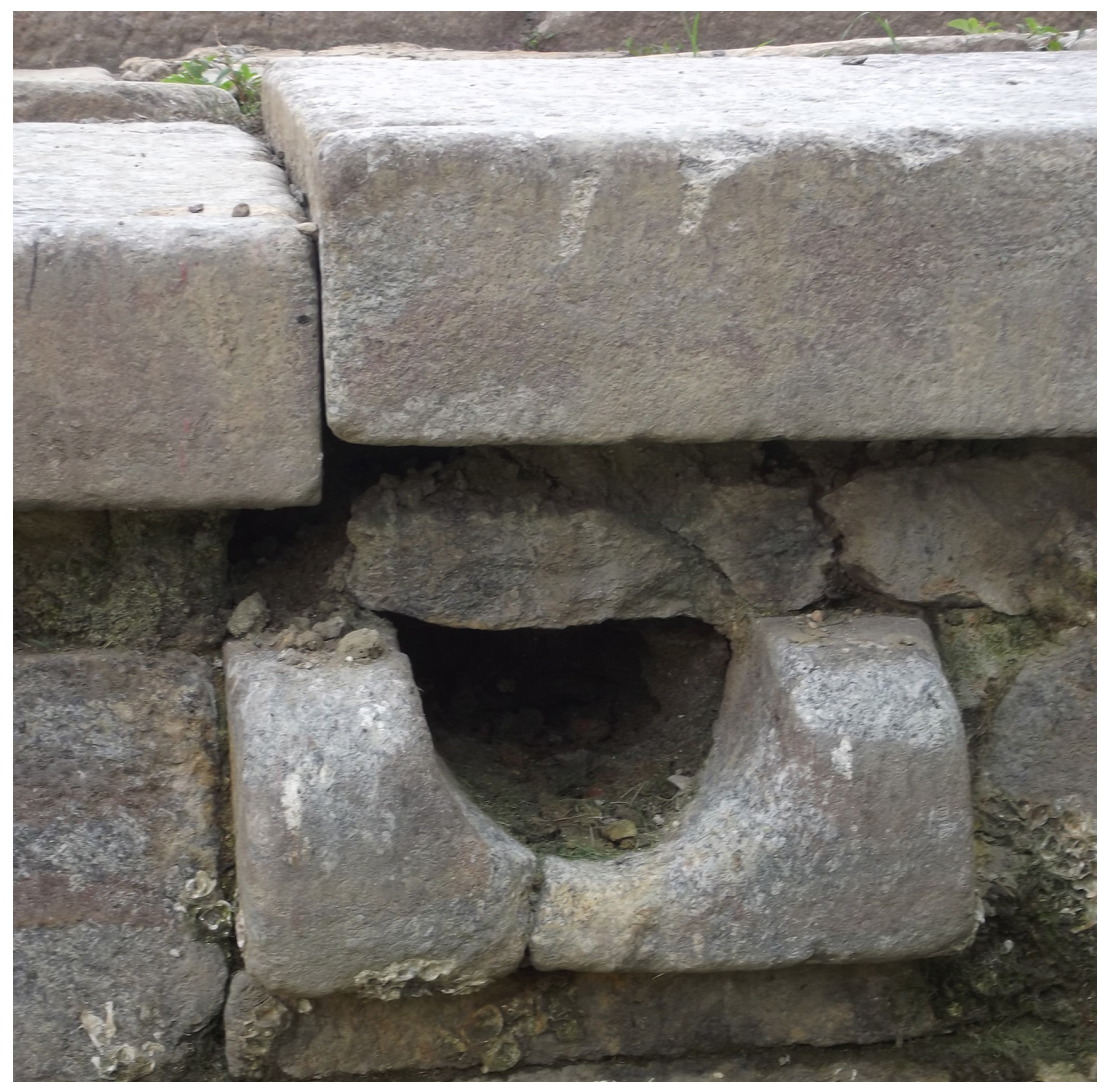

Figura 107 - Bica instalada no lado oposto, a 0,50 m de profundidade da superfície do cais, na Frente 2, para guardar simetria com a anterior. 
Também nessa década foi iniciada e concluída a construção das Docas D. Pedro II, transformando radicalmente a paisagem local, sob vigorosos protestos da população e de segmentos que se sentiram prejudicados com a iniciativa. No lançamento da pedra fundamental da edificação - encontrada nas escavações -, feito pela princesa regente Isabel Cristina e pelo príncipe consorte, Conde d'Eu, os jornais mencionaram obras que estavam sendo realizadas na praça, bem como os reclamos dos moradores contra o desmanche do calçamento, já pronto, para a colocação da pedra, uma evidência de que o local estava sendo reformado.

Foi igualmente nessa década que o antigo projeto de execução de um monumento à chegada da Imperatriz ao Brasil, nunca realizado, foi retomado. Não mais o grandioso chafariz projetado por Grandjean de Montigny, mas uma versão empobrecida, de um discípulo seu, foi aprovada pela Câmara, sendo finalmente instalada na praça a coluna encimada pela esfera armilar e as três setas do martírio de São Sebastião, emblema da cidade, com quatro bicas em seu entorno e uma bacia retangular de captação das águas. Ela se encontra até hoje no local, embora tenham sido retiradas as bicas e a bacia originais. Esse conjunto de iniciativas atesta sem dúvida o empenho na revitalização e no enobrecimento da Praça Municipal e do Cais da Imperatriz nos anos 1870.

A estrutura do cais, tal como se encontra hoje, uma vez exposta pelas escavações arqueológicas, retrata bem, por sua vez, esse processo. Não obstante a robustez do seu sistema construtivo, ela sucumbiu à força das águas - tanto as provenientes do mar quanto aquelas da drenagem terrestre - e aos impactos contínuos produzidos pelas pequenas embarcações que seguidamente aportavam naquele atracadouro. Da década de 1870 em diante, foram feitas diferentes tentativas de manter, tanto quanto possível, a estrutura operante, como o reposicionamento dos degraus de acesso à praça para a construção improvisada de um dissipador de energia hidráulica (decerto em época tardia), para atenuar os estragos feitos pelo mar; o preenchimento com pedras de mão no rombo aberto na sua base (na qual uma delas apresenta marca de dinamite, um indicador cronológico do último quartel do século XIX), para evitar seu desabamento; ou a tentativa de soerguer com pedras a camada de grandes lajotas da plataforma, em perigosa inclinação, para que não deslizassem para o mar. Contudo, as infiltrações no subsolo das águas provenientes do Morro do Livramento, que desciam pela sua ladeira em enxurradas, parecem ter sido fatais para a sustentação da estrutura, tendo determinado o seu solapamento justo no trecho correspondente ao caminho percorrido por elas até o mar. Em 1891, o registro documental fez menção à necessidade de reconstrução das paredes da "parte abatida" do cais, expressão que pode corresponder tanto ao rombo na sua base quanto ao seu afundamento. A tensão a que essa estrutura ficou submetida com tantas avarias é visível nas grandes rachaduras verticais em três das lajotas que a compõem, atestando que seu colapso teria sido inevitável, mais cedo ou mais tarde, se ela não tivesse sido soterrada pelas grandes reformas do início do século XX. 
Não obstante todos os esforços feitos e o empenho para revitalizar a área, a degradação se reinstalou. A queixa de um morador na década de 1890 relatava o abandono, a imundície e o arruinamento da praça, frequentada por marginais, imigrantes sem qualificação e desocupados de toda sorte. As obras de saneamento e reurbanização feitas no início do século XX para a construção do Porto do Rio de Janeiro deveriam, a rigor, ter requalificado a área. Contudo, historicamente associada a segmentos considerados como marginalizados pela sociedade dominante - como os negros escravizados em sua origem, os alforriados que por lá se estabeleceram e se fixaram, e depois aos negros libertos que, com a construção do porto, foram alocados na estiva, ou mesmo aos imigrantes de proveniências distintas que ali se refugiavam - a área ficou fortemente marcada como um reduto da marginalidade, não obstante serem eles, em grande parte, a principal força de trabalho que movia a cidade. A esses segmentos se somava a marinhagem que povoa habitualmente as zonas portuárias, de tal forma que esse estigma se sobrepôs a todas as tentativas de dignificar a região, mantendo-se até os tempos atuais.

Entretanto, foi precisamente por conta desse estigma que sobreviveram algumas das mais vigorosas manifestações culturais da população afrodescendente nela radicada, que constituem hoje um patrimônio inestimável da nação brasileira, a ser preservado. No momento em que a zona portuária do Rio de Janeiro se prepara para uma nova mudança de rumos e onde estão sendo executados projetos modernizadores destinados a transformá-la radicalmente, o grande desafio será a conciliação da chegada da modernidade com a manutenção dos modos de vida tradicionais da zona portuária e a preservação do seu patrimônio histórico.

\section{A reurbanização da Praça Jornal do Commercio}

Em decorrência da nova configuração que a Praça Jornal do Commercio assumiu em virtude do achado do Cais do Valongo, ela foi reurbanizada à luz de um projeto desenvolvido em 2011 pela então Subsecretaria de Patrimônio Cultural, Intervenção Urbana, Arquitetura e Design, transformada, em 2012, no Instituto Rio Patrimônio da Humanidade. Atendendo a essa nova concepção, foi rebaixado o nível da antiga praça em $0,60 \mathrm{~m}$ e nivelado para assentamento de um novo piso em placas de granito, tendo sido reimplantadas as palmeiras e árvores nela previamente existentes, retiradas em caráter provisório para a execução da obra (Figuras 108 a 1 10). Muros de arrimo foram construídos nos limites com as Frentes 3 e 5, somandose aos das Frentes 2 e 4, e assim completando seu entorno. Todas essas atividades implicaram intervenções no subsolo, que receberam o devido acompanhamento arqueológico. Contudo, não foram encontrados nem estruturas nem vestígios arqueológicos na profundidade alcançada, salvo alguns poucos fragmentos descontextualizados, sugerindo tratar-se de material misturado a aterro. Cabe destacar que, em profundidade em torno de 1,20 a 1,30 m, encontra-se o piso de terra batida, bastante compactado, identificado nas sondagens realizadas na praça. 


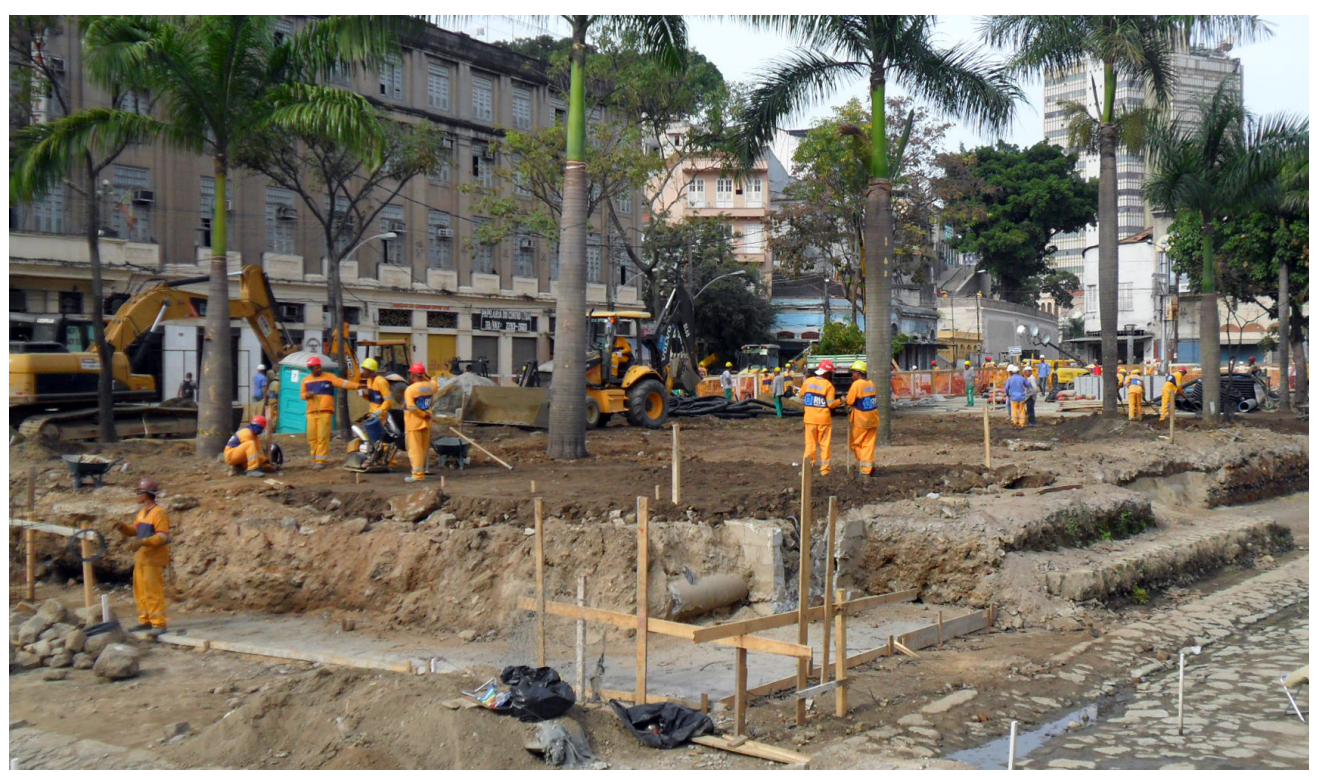

Figura 108 - Nivelamento do piso da praça.

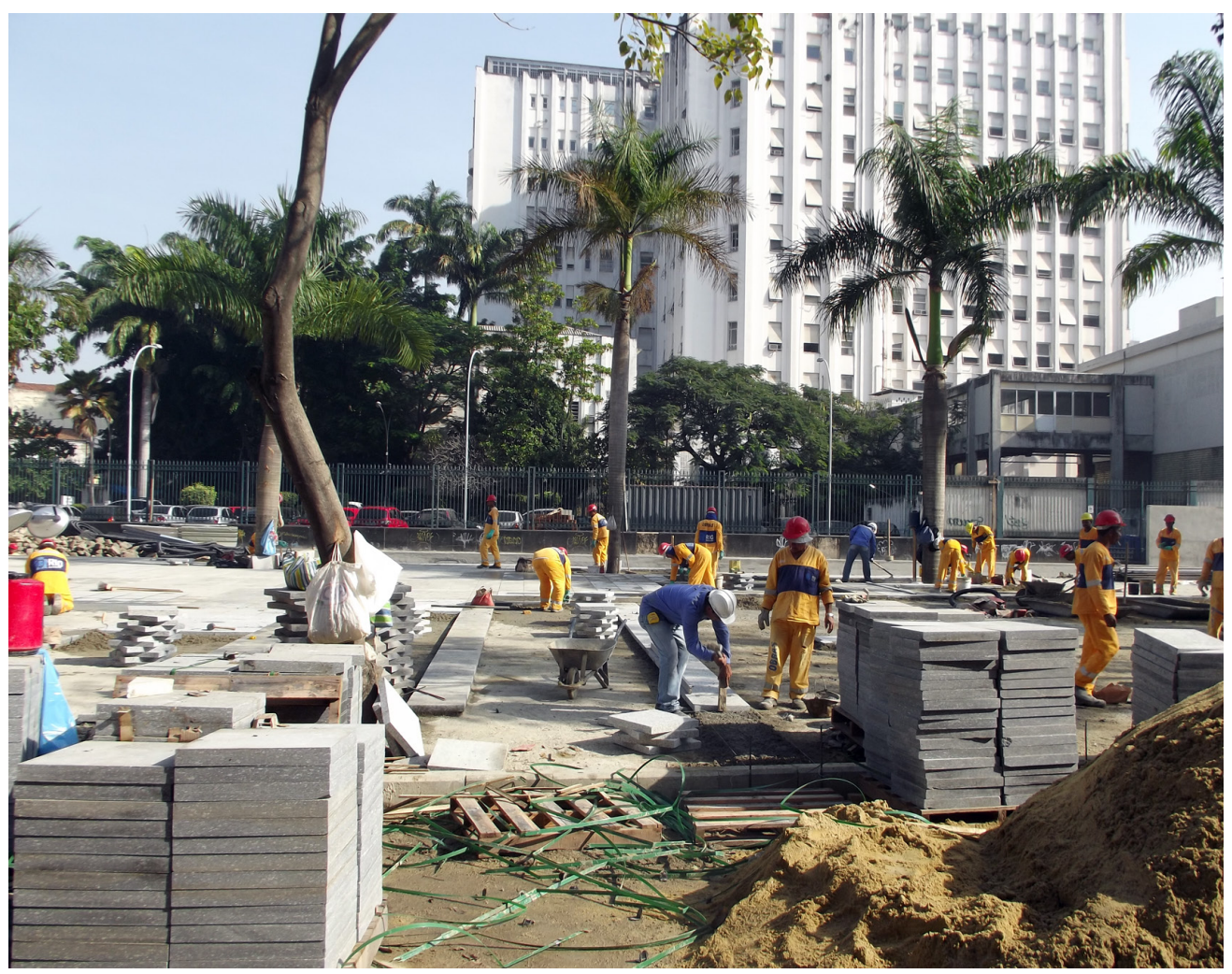

Figura 109 - Assentamento do novo calçamento com placas de granito

Annals of Museu Paulista. v. 24. n.1. Jan.-Abr. 2016. 


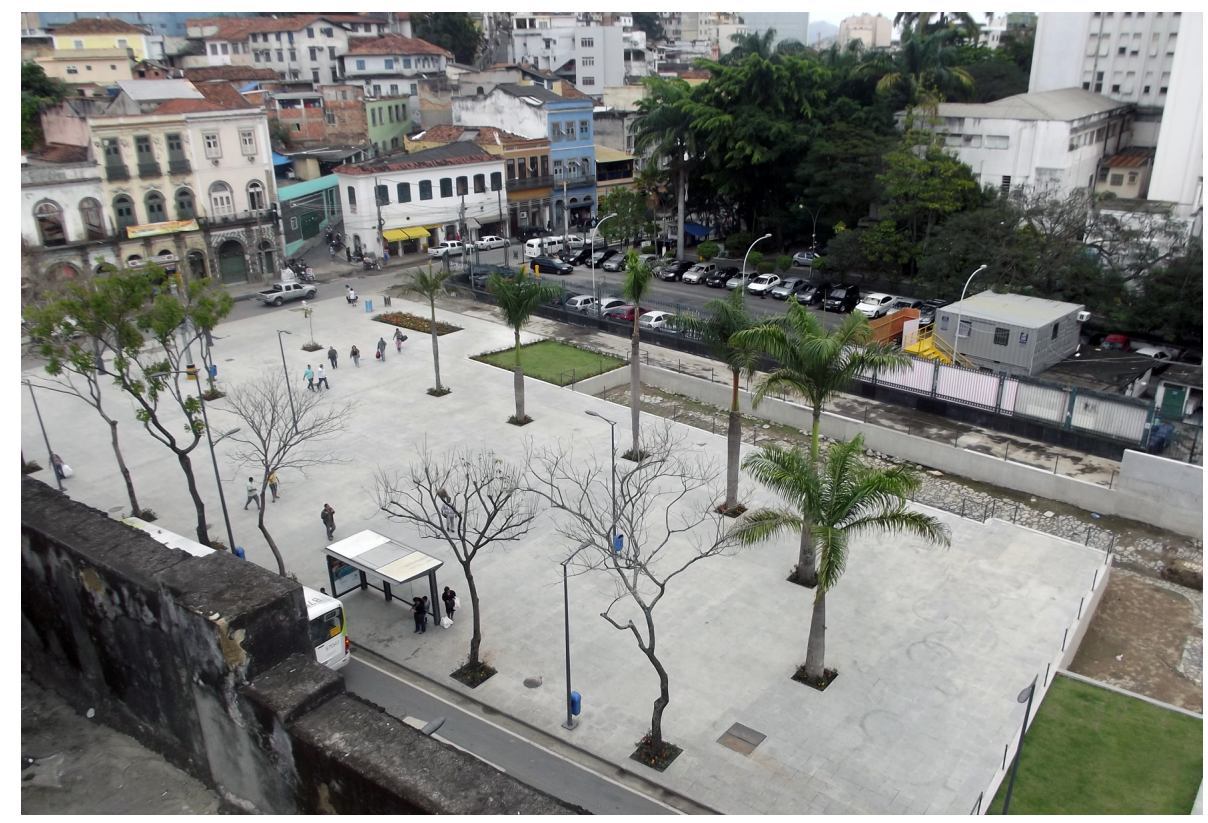

Figura 110 - A Praça Jornal do Commercio reubanizada

De modo a guardar em segurança as pedras retiradas do calçamento do Cais do Valongo e do Cais da Imperatriz para a construção das calçadas laterais, foi feito um depósito provisório para o seu armazenamento controlado, até que venha a ser feito o trabalho de reconstituição dos elementos faltantes e de consolidação dos calçamentos. As pedras foram recobertas com o geotêxtil bidim e areia lavada (Figura 111 1, e sobre esse depósito foi feito um gramado ornado com flores à toda volta, integrado à paisagem mais ampla da praça (figs. 112 e 113 ).

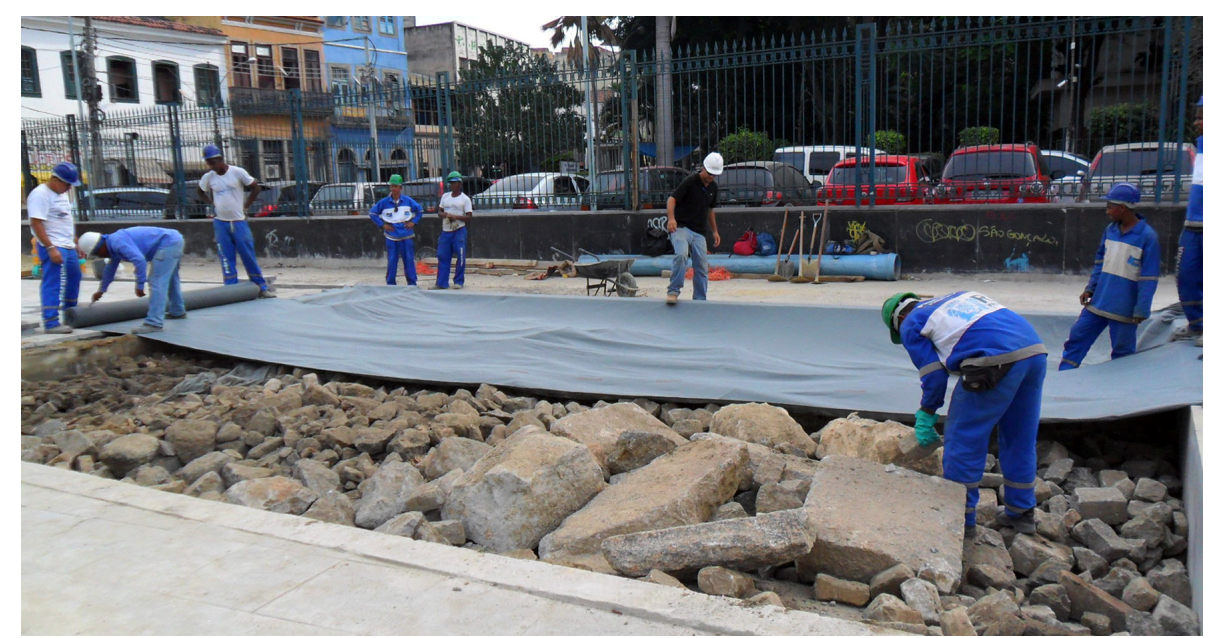

Figura 111 - Área de armazenamento provisório das pedras retiradas do Cais do Valongo e do Cais da Imperatriz, aguardando o trabalho de recomposição do seu calçamento, e recobrimento do depósito provisório com o geotêxtil bidim para fins de proteção. 

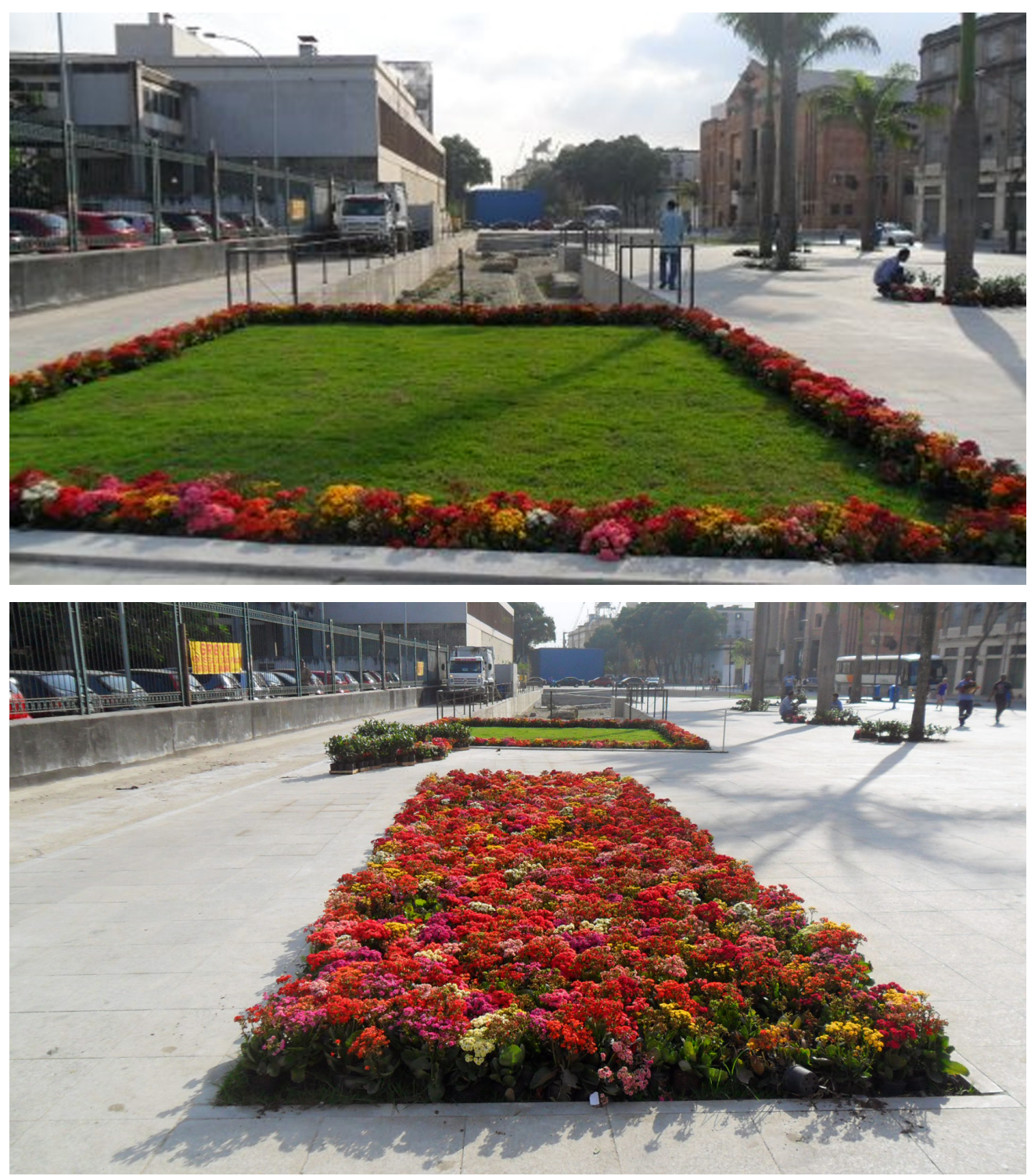

Figuras 112 e 113 - Ajardinamento da área de armazenamento provisório das pedras.

A reurbanização da área do cais

A área em frente aos antigos Cais do Valongo e Cais da Imperatriz também foi reurbanizada, de modo a possibilitar a visita do público ao sítio arqueológico. Escadas, rampas de acesso e um ponto de observação foram construídos, proporcionando um local de reflexão para os que visitam aquele que foi tanto o ponto de chegada ao Brasil de centenas de milhares de africanos para serem escravizados, quanto da princesa das Duas Sicílias, Teresa Cristina Maria de Bourbon, por ocasião do seu casamento com D. Pedro II (Figuras 114 a 1191. 

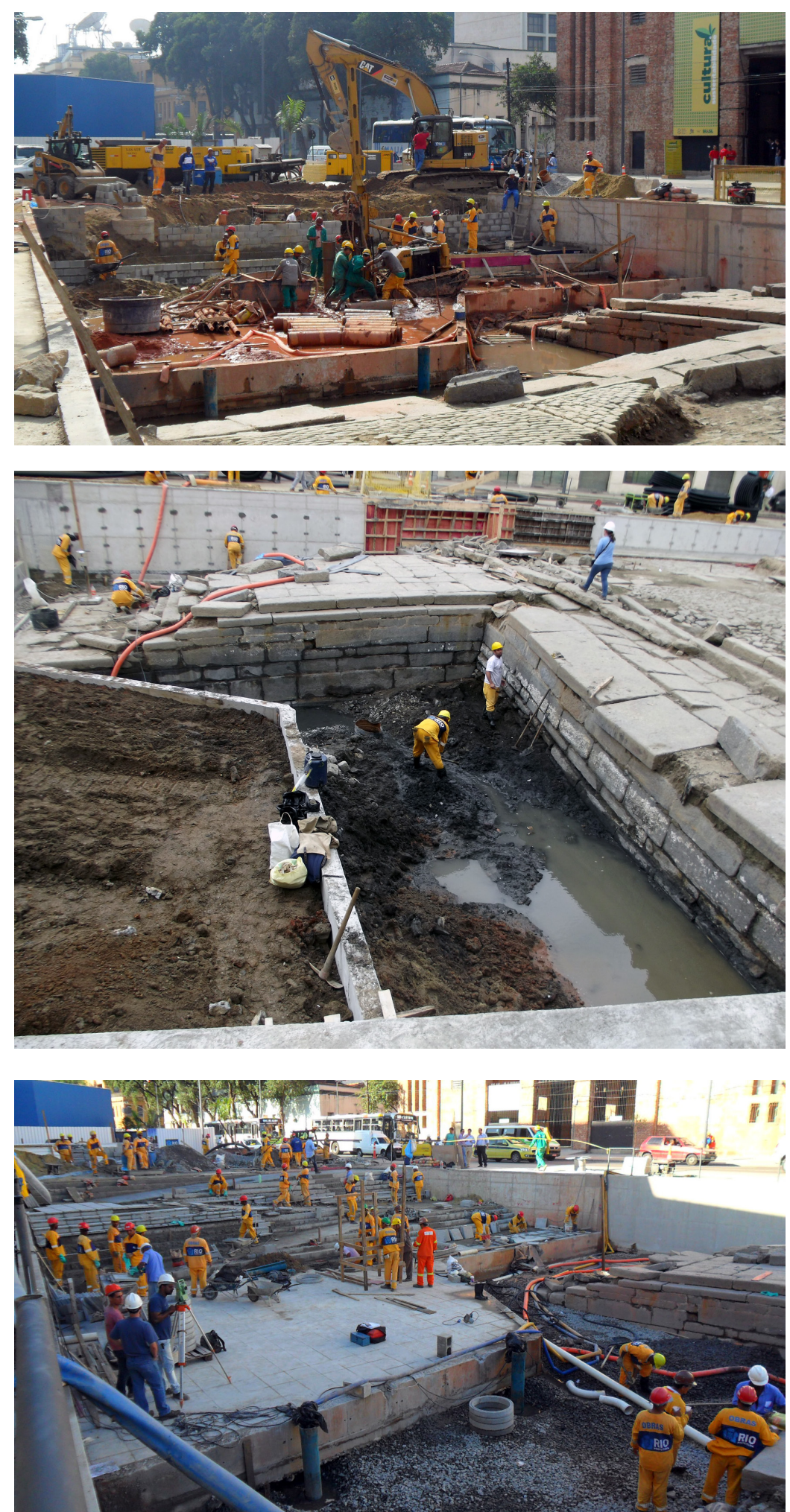

Figuras 114 a 116 - As obras de urbanização da área em frente ao Cais do Valongo / Cais da Imperatriz. 


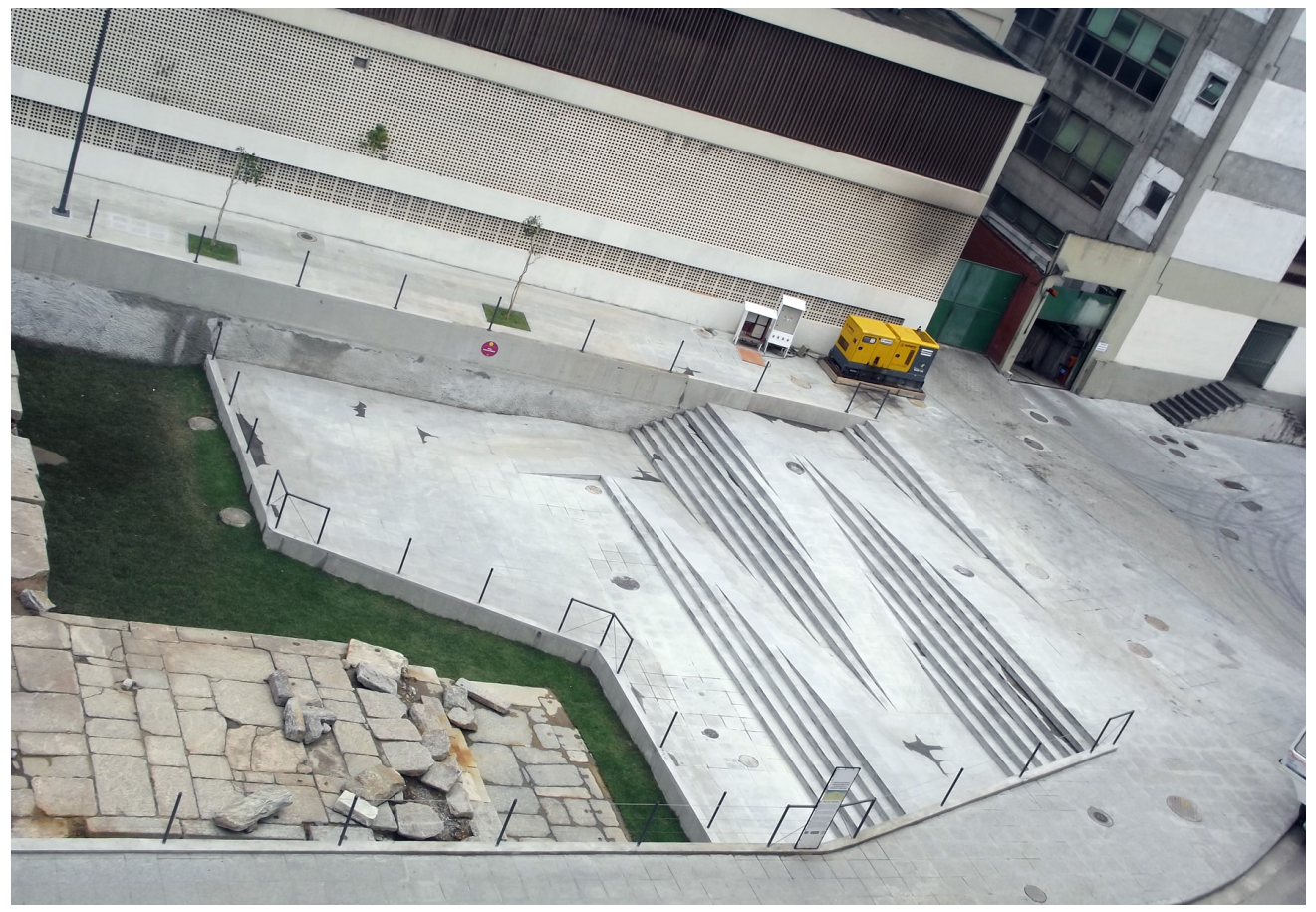

Figura 117 - Escadas, rampas de acesso e ponto de observação para o público

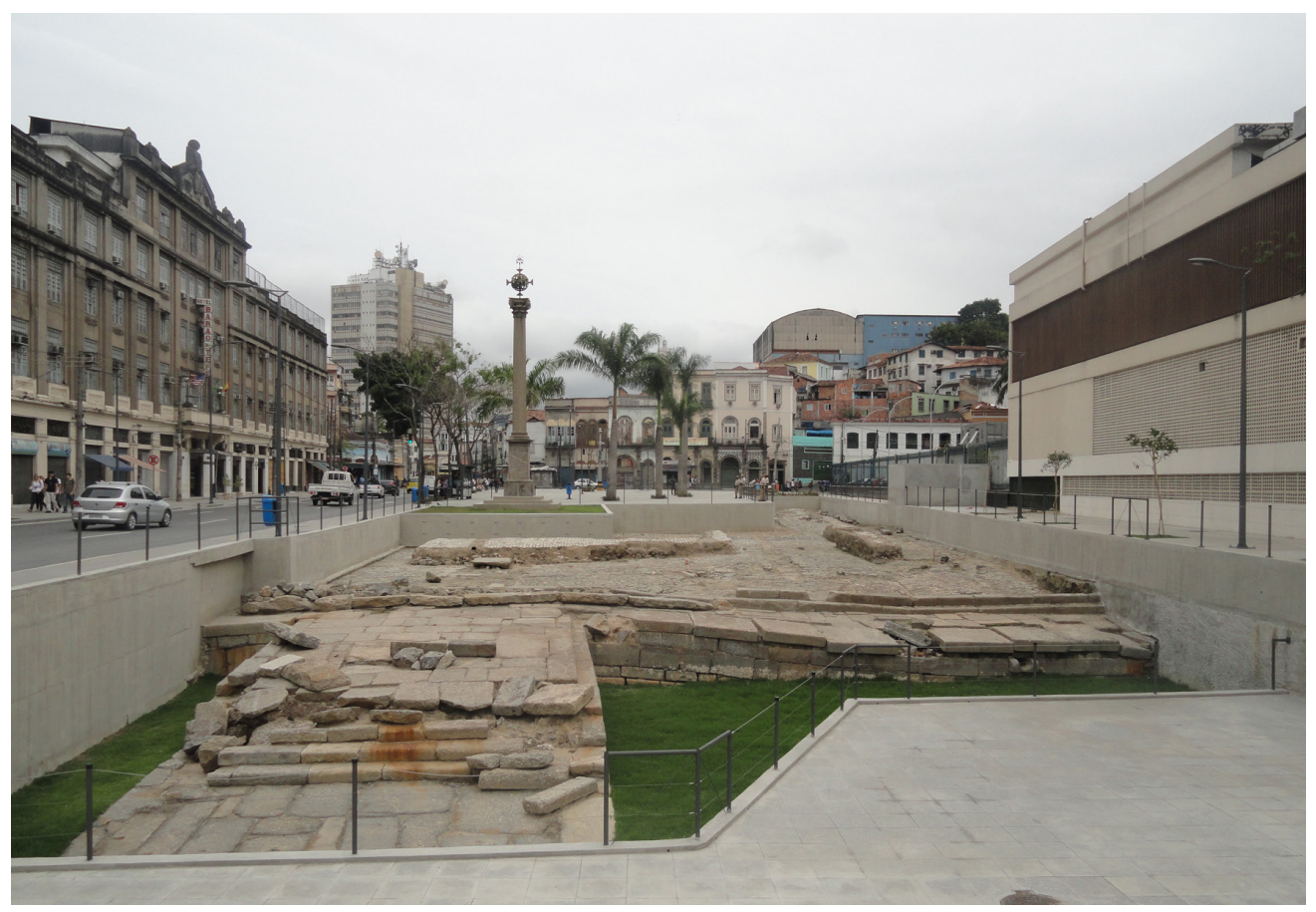

Figura 118 - A rampa de desembarque do cais, cujos paredões foram aterrados para fins paisagísticos à época da inauguração, em 01 de julho de 2012, muito acima do nível recomendado pela equipe de Arqueologia. Esse aterro atenuou a grandiosidade da estrutura, impedindo a visão do seu sistema construtivo e dos processos ocorridos ao longo de sua história. 


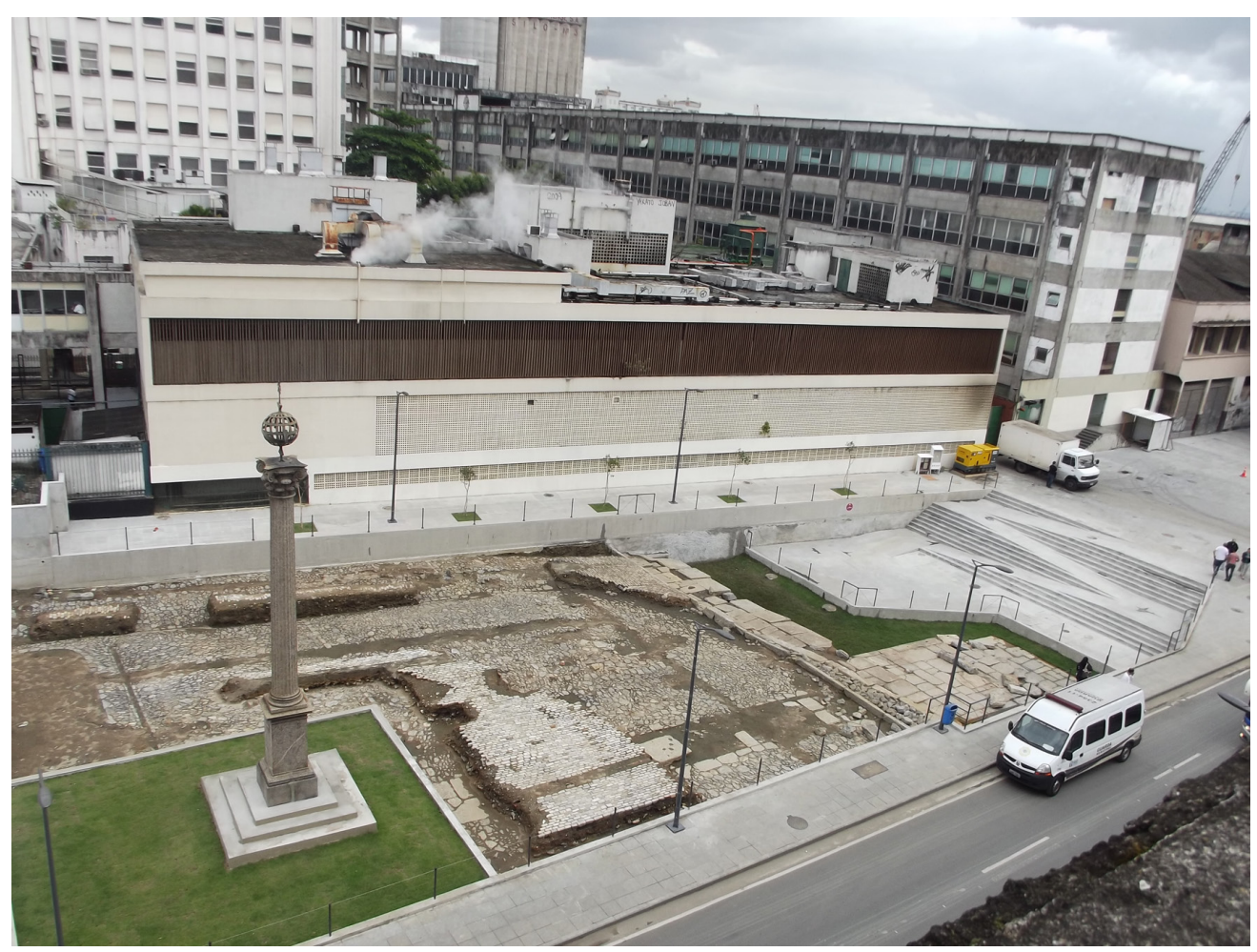

Figura 119 - Cais do Valongo e Cais da Imperatriz reurbanizados.

Cais do Valongo, candidato a patrimônio mundial

À medida que os achados do Valongo foram sendo intensamente divulgados no Brasil e no exterior, diferentes vozes começaram a levantar a bandeira do seu reconhecimento como patrimônio mundial pela Unesco, em vista do seu vigoroso significado político e social e sua dimensão fortemente simbólica.

Tornando-se cada vez mais audíveis e alcançando instâncias mais elevadas do governo federal, essas vozes se expressaram concretamente nessa direção por ocasião da realização do Seminário Internacional "Herança, Identidade, Educação e Cultura: gestão dos sítios e lugares de memória ligados ao tráfico negreiro e à escravidão", realizado em agosto de 2012, em Brasília. Promovido pela Fundação Palmares e pela Organização das Nações Unidas pela Educação, a Ciência e a Cultura, esse evento foi um dos frutos do projeto internacional Rota do Escravo: resistência, liberdade e herança, desenvolvido pela Unesco, tendo contado com a presença de membros do seu Comitê Científico e do coordenador do projeto, o cientista político Ali Moussa lye, Diretor do Setor de História e Memória para o Diálogo. Na cerimônia de abertura, a então Ministra da Cultura, Ana de Hollanda, e a Ministra da lgualdade Racial à época, Luiza Bairros, reivindicaram, perante os membros da Unesco presentes, a sua inscrição na lista do Patrimônio Mundial, em reconhecimento a sua alta relevância. 
No ano seguinte, em 2013, foi realizada no Rio de Janeiro a reunião estatutária do Conselho Científico Internacional do Projeto Rota do Escravo, ocasião em que foi reconhecida a importância do Sítio Arqueológico Cais do Valongo como lugar de memória da Diáspora Africana nas Américas. Para expressar esse reconhecimento, foi afixada no local uma placa, a primeira do gênero em todo o mundo, assinalando se tratar de sítio reconhecido pela Unesco. Essa cerimônia foi realizada emblematicamente em 20 de novembro de 2013, Dia da Consciência Negra. A candidatura do Sítio Arqueológico Cais do Valongo a Patrimônio Mundial recebeu apoio unânime do Comitê Científico Internacional, mais uma vez reiterado por ocasião da reunião do Projeto Rota do Escravo em 2014, na cidade do México.

Cabendo ao Instituto do Patrimônio Histórico e Artístico Nacional, órgão do Ministério da Cultura, a condução desse processo e a elaboração do dossiê de inscrição da candidatura, foi por ele convocada uma força tarefa, com o objetivo de preparar o documento, composta por membros do Iphan e de diferentes órgãos da Prefeitura do Rio de Janeiro diretamente relacionados com a questão (Secretaria da Cultura, de Relações Internacionais, Instituto Rio Patrimônio da Humanidade, Companhia de Desenvolvimento Urbano da Região do Porto e Coordenadoria Especial de Políiticas de Promoção da lgualdade Racial do Rio de Janeiro). Além deles, compuseram essa força tarefa um grupo de trabalho interdisciplinar e interinstitucional constituído por três membros, sob a coordenação geral do antropólogo Milton Guran, e um Conselho Científico integrado por 40 membros de diferentes áreas, em especial por representantes da comunidade negra e órgão de defesa de seus direitos. Esse Conselho Consultivo foi instalado em 30 de setembro de 2014, no Palácio Gustavo Capanema, no Rio de Janeiro, sob a condução da Presidente do Iphan, Jurema Machado.

Decorrido um ano de esforço conjunto para a elaboração do dossiê, a candidatura foi formalizada pelo governo brasileiro junto à Unesco, por meio do Iphan, em setembro de 2015 , precisamente ao se inaugurar a Década Internacional das Pessoas de Descendência Africana, resolução adotada pela Assembleia Geral da Organização das Nações Unidas, em dezembro de 2013 . Entre 01 de janeiro de 2015 e 31 de dezembro de 2024, a ONU estimulará reflexões e ações afirmativas em torno do tema Pessoas com Descendência Africana: reconhecimento, justiça e desenvolvimento.

Nesse contexto, a candidatura do Cais do Valongo à inscrição na lista do Patrimônio Mundial da Unesco, encaminhada pelo Iphan, encontra-se em apreciação. 


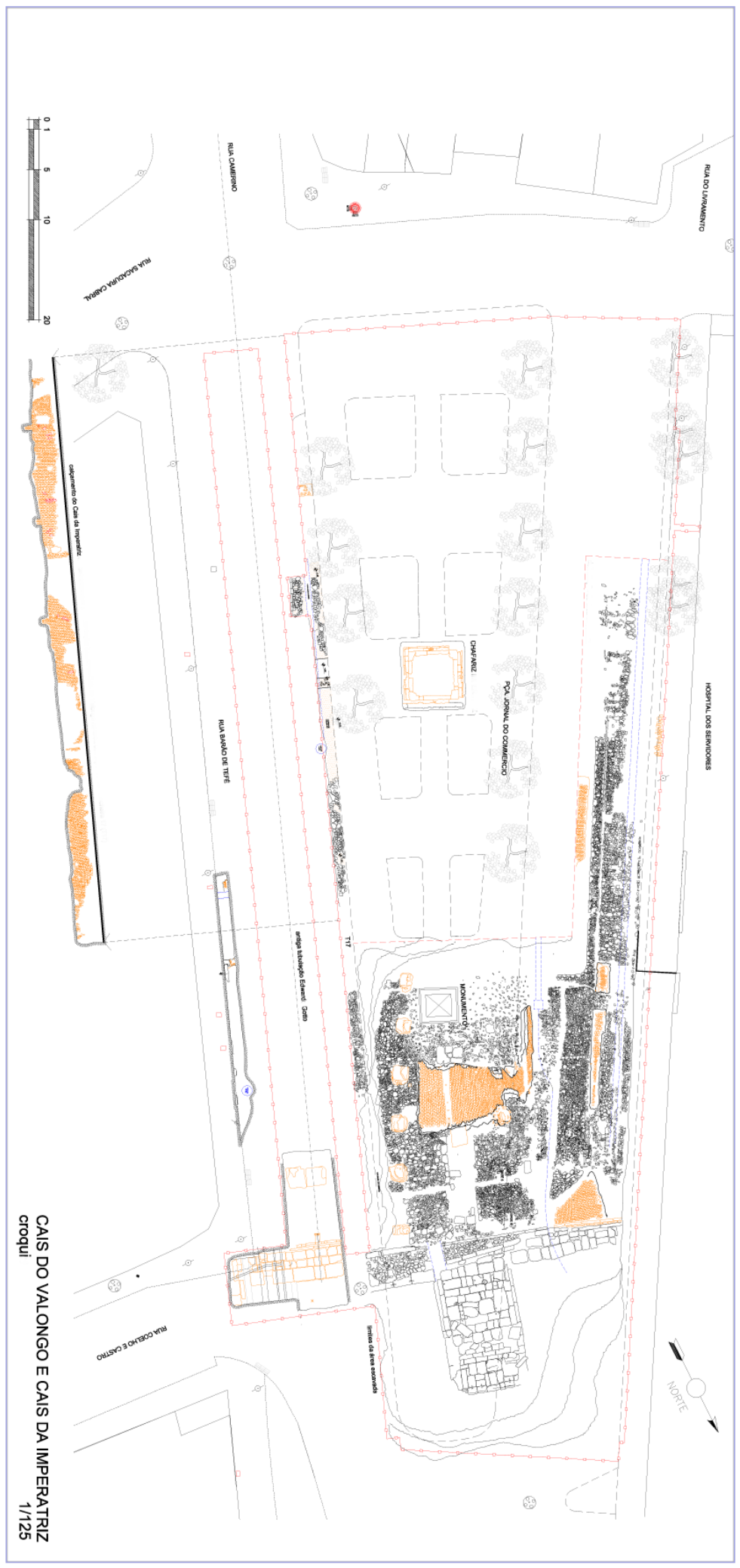

Figura 120 - Croqui do Cais do Valongo e do Cais da Imperatriz. Em preto, o calçamento em pé-de-moleque do Cais do Valongo; em laranja, o calçamento de paralelos do Cais da Imperatriz. Autoria: Estudio Soma 


\section{REFERÊNCIAS}

\section{FONTES PRIMÁRIAS}

Arquivo Nacional, Rio de Janeiro

Instruções do Marquês do Lavradio ao seu sucessor como Vice-Rei, Caixa 746, Fundo Vice Reinado.

Aforamentos, BR RJ AN RIO, BI O D16 O O389, fl. 9.

Arquivo Geral da Cidade do Rio de Janeiro, Rio de Janeiro

Códice 1-2-67, Coleção Aforamentos, Planta do Cais do Valongo, 1837.

Códice 32.1.43, fl. 75, de 14 de agosto de 1843.

Códice 36.2.1 Série Ofícios da Câmara Municipal, fls. 163, 167.

Códice 36.2.4, Série Ofícios da Câmara Municipal, fls. 86, 260.

Códice 40.2.67, Fundo Câmara Municipal, Série Cais, fls. 47, 48, 50, 51, 52, 54, 55, 56, 57, 76, 77, 78, 79, 87, 88, 89, 91, 98, 99, 101, 103, 114.

Códice 40.2.73, Fundo Câmara Municipal, Série Cais, fls. 35, 103, 105, 106, 107, 108.

Códice 40.2.76, Fundo Câmara Municipal, Série Cais.

Códice 40.3.13, Fundo Câmara Municipal, Série Cais, fls. 71, 72, 89.

Códice 46.3.26.

Códice 49-1-5.

Códice 49.1.54., fl. 1, 1v.

Códice 67.1.12.

Biblioteca Nacional, Rio de Janeiro

Diário do Rio de Janeiro, n. 20, de 26 de março de 1822.

Diário do Rio de Janeiro, PR-SPR 0005, de setembro 1871.

Manuscritos, BN II-34, 26, 19. "Representação dos proprietários, consignarários e armadores de resgate de escravos a SAR [RJ, 1811]”. 


\author{
Manuscritos, 63.05.006, n. 029. \\ Manuscritos, C-0449, 045. \\ Manuscritos, C-0463, 054, n. 001. \\ Manuscritos, C-0465, 057. \\ Manuscritos, C-0704, 024, n. 001. \\ Manuscritos, C-0734, 045. \\ Manuscritos, C-0786, 068. \\ Manuscritos, C-0786, 072. \\ Manuscritos, C-0797, 020. \\ Manuscritos, C-0941, 004, n. 002.
}

Instituto Histórico e Geográfico Brasileiro, Rio de Janeiro

Abreviada demonstração dos trabalhos da polícia em todo tempo em que serviu o Desembargador do Paço Paulo Fernandes Vianna. Revista do Instituto Histórico e Geográfico Brasileiro, Tomo 55, Parte 1, Rio de Janeiro: Companhia Typographica do Brasil, p. 373-74, 1892.

Superintendência do Iphan, Rio de Janeiro

Relatório Cais do Valongo / Cais da Imperatriz. Caderno com 111 pranchas, em depositado janeiro de 2013.

\title{
LIVROS, ARTIGOS E DISSERTAÇÕES
}

ALVARÁ de Regimento de 22 de janeiro de 1810. In: Leis Históricas. Disponível em: <http:// www.planalto.gov.br/ccivil_03/revista/Rev_70/alvara.htm>, acesso em 28 abr. 2015.

CORREA, Armando de Magalhães. Terra Carioca: fontes e chafarizes. Revista do Instituto Histórico e Geográfico Brasileiro, Rio de Janeiro, v. 170, p.1-214 1935.

ELTIS, David; HALBERT, Martin (Eds.). Voyages: Trans-Atlantic Slave Trade Database, 2008. Disponível em: http://slavevoyages.org, acesso em 26 jun. 2014.

FLORENTINO, Manolo. Em costas negras: uma história do tráfico atlântico de escravos entre a África e o Rio de Janeiro : séculos XVIII e XIX. São Paulo: Companhia das Letras, 1997.

GERSON, Brasil. História das ruas do Rio. Rio de Janeiro: Lacerda, 2000. 
GOTTO, Edward. Plan of the City of Rio de Janeiro. Londres: Robert J. Cook, 1871.

HONORATO, Claudio de Paula. Valongo: o Mercado de escravos do Rio de Janeiro, 1758 1831. 2008. Dissertação (Mestrado em História) - Instituto de Ciências Humanas e Filosofia, Universidade Federal Fluminense, Niteroi, 2008.

LAMARÃO, Sergio Tadeu de Niemeyer. Dos trapiches ao porto: um estudo sobre a área portuária do Rio de Janeiro. Rio de Janeiro: Coleção Biblioteca Carioca, 2006.

LIMA, Tania Andrade. A la recherche du Valongo: le quai des esclaves à Rio de Janeiro, XIXème siècle. In: DELPUECH, André; JACOB, Jean-Paul (Orgs.). Archéologie de l'esclavage colonial. Paris: La Découverte, 2013a, p.113-127.

LIMA, Tania Andrade. Arqueologia como ação sociopolítica: o caso do cais do Valongo, Rio de Janeiro, século XIX. Vestígios, Revista Latinoamericana de Arqueologia Histórica, Belo Horizonte, v.1, n.7, p.177-204, 2013b.

LIMA, Tania Andrade; TORRES DE SOUZA, Marcos André; SENE, Glaucia Malerba. Weaving the second skin: Protection against Evil among the Valongo Slaves, Nineteenth Century Rio de Janeiro. Journal of African Diaspora Archaeology \& Heritage, v.3, n.2, p.103-136, 2014.

MARQUES, Eduardo Cesar. Da higiene à construção da cidade: o Estado e o saneamento no Rio de Janeiro. História, Ciências, Saúde - Manguinhos, Rio de Janeiro, v. II, n. 2, p.51-67, 1995.

PEREIRA, Júlio Cesar Medeiros. À flor da terra: o cemitério de pretos novos no Rio de Janeiro. Rio de Janeiro: Garamond, Iphan, 2007.

PONTIFÍCIA Universidade Católica do Rio de Janeiro (Org.). Uma cidade em questão I: Grandjean de Montigny e o Rio de Janeiro. Rio de Janeiro, Pontifícia Universidade Católica do Rio de Janeiro; Funarte; Fundação Roberto Marinho, 1979.

ROHAN, Henrique de Beaurepaire. Remodelação do Rio de Janeiro. Relatório apresentado à Câmara Municipal em 1843. Revista do Instituto Histórico e Geográfico Brasileiro, Separata do v. 275, abril/junho de 1967. Rio de Janeiro: Imprensa Nacional, 1968.

SANTOS, Renata, RIBEIRO, Marcus Venício; LYRA, Maria de Lourdes Viana (Orgs.). O acervo iconográfico da Biblioteca Nacional: estudos de Lygia da Fonseca Fernandes da Cunha. Rio de Janeiro: Ministério da Cultura, Fundação Biblioteca Nacional, 2010. 